STATEOT ALASIA

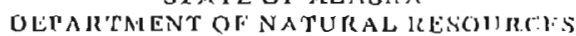

INCLINOMETER STRAIN ANALYSES OF ANCHORAGE LANDSLIDES, 1965-80

By

Randall G. Updike

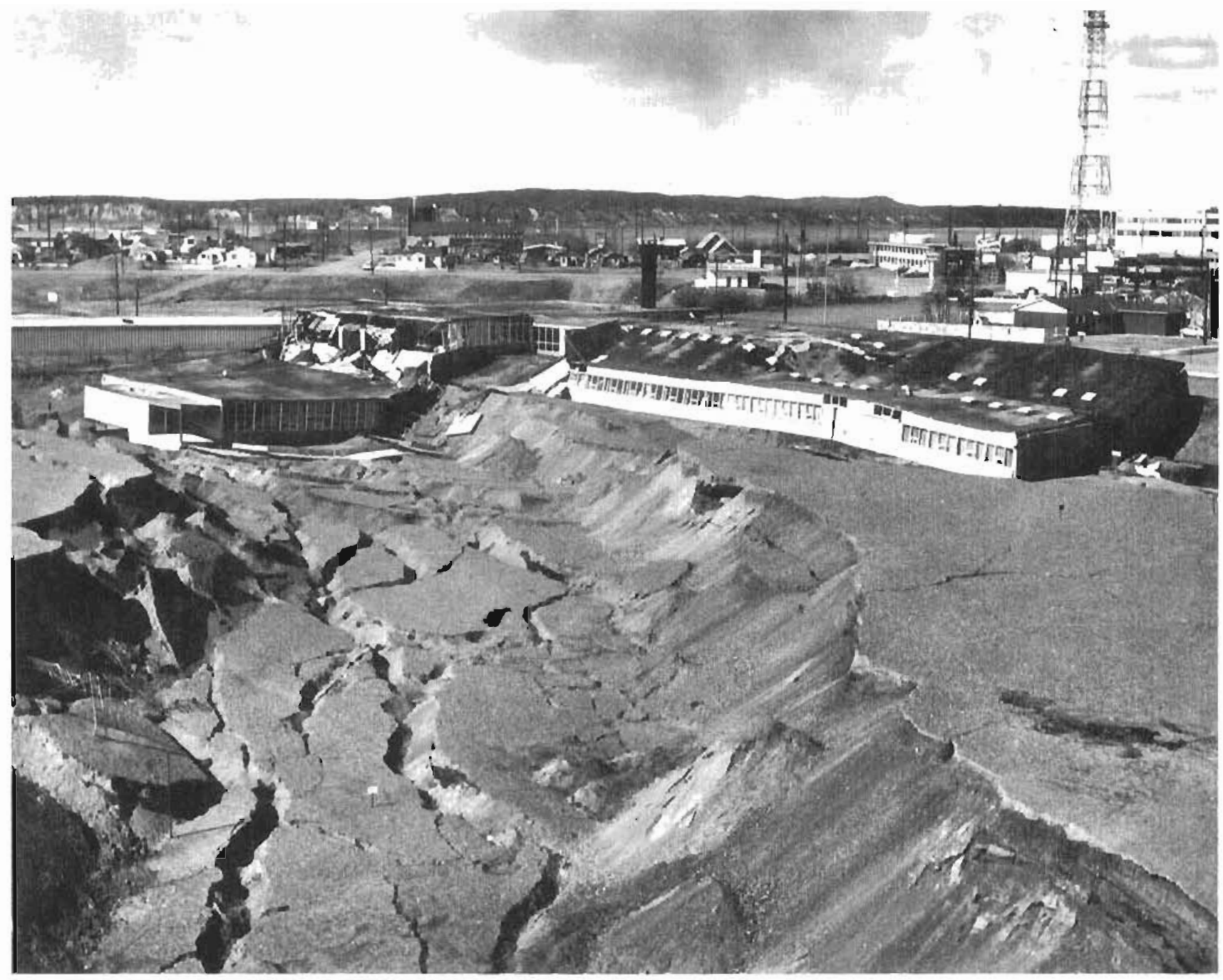

PROFESSIONAL REPOR'T 80

Publitharal by

DIVISION OI GIOLOGICAL \& GEOPHYSICAL SURVEXS

ROSS G. SCHATF

STATE. GFOLUGIST

1983 
PROFESSIONAL REPORT 80

INCLINOMETER STRAIN ANALYSES OF ANCHORAGE LANDSLIDES, 1965.80

By

Randall G. Updike

Supporled under a Cooperative Research Project with the Office of Earthquake Studies, Earthquake Hazards Reduction Program, U.S. Geological Survey

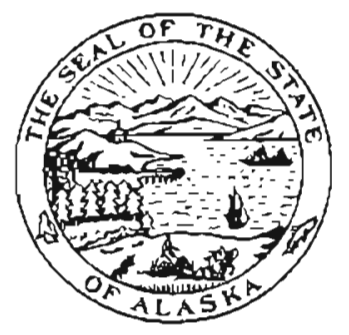


STATE OF ALASKA

Bill Sheffield - Governor

Esther Wunnicke - Commissioner

Ross G. Schaft - Stale Geologist

Cover photo: Grabenlike soil failure destroyed the Anchorage Government Hill School, March 27, 1964. (Pholo-B77.118.121--courtesy Anchorage Historical and Fine Arts Museum; U.S. Army Corps of Engineers pholo negative 398.)

For sale by Alaska Dlvision of Geological and Geophysical Surveys, P.O. Box 80007. College. 99708: 3601 C Si. (10th floor). Anchor age, 99503: P.o. Box 2438, Ketchikan. 99901: and 230 S. Franklin, Juneau, 9981 1. Cost: \$4. 


\section{CONTENTS}

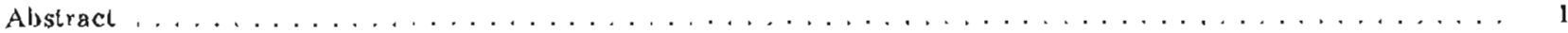

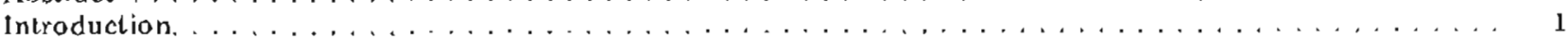

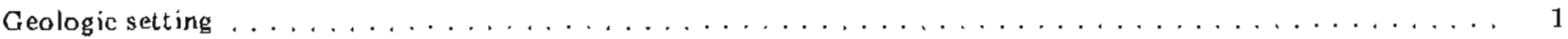

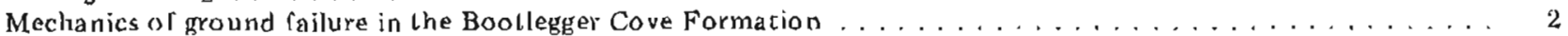

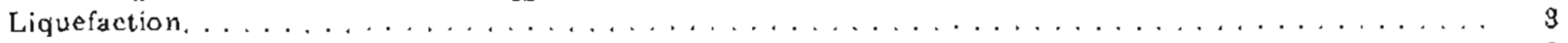

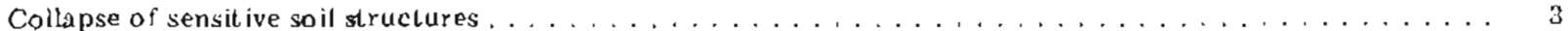

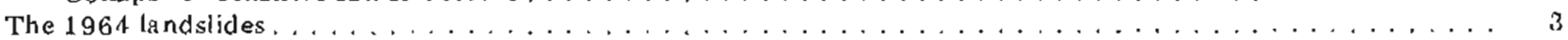

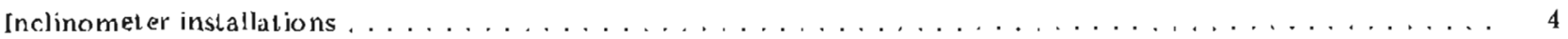

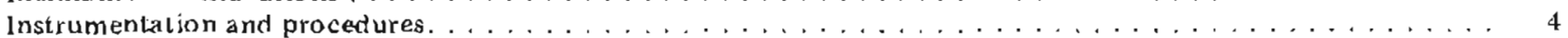

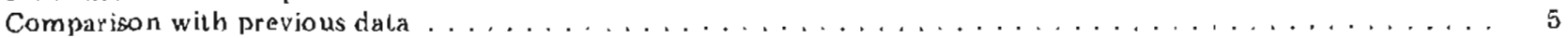

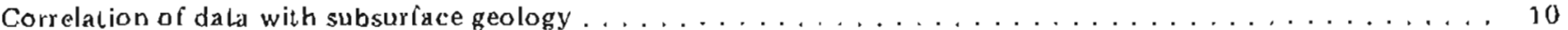

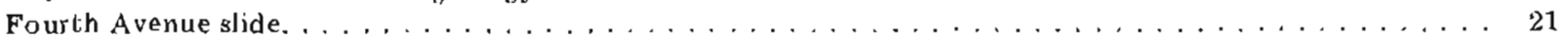

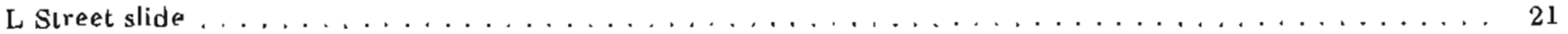

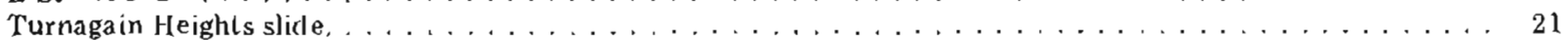

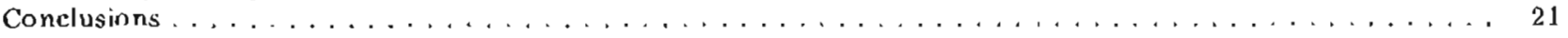

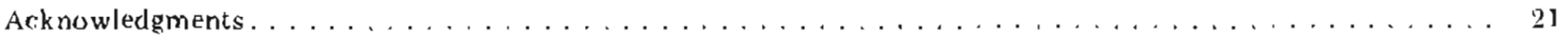

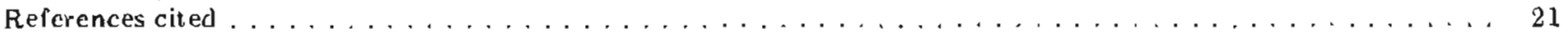

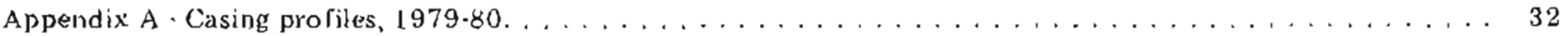

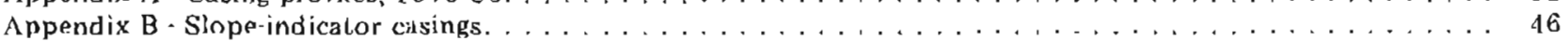

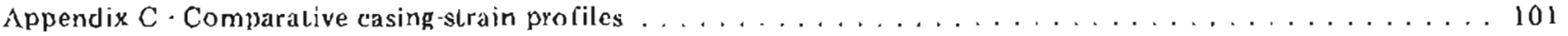

FIGURES

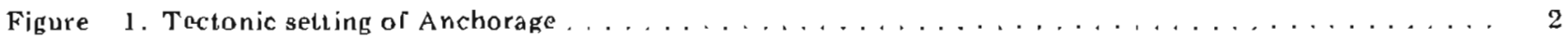

2. Map of the Anchorage area showing approximate location of 1964 seismic-induced landslides . . . . . 1

3. Turnagain Heights area immediately following 1964 earthquake. . . . . . . . . . . . . . 5

4. Fourth A venue slide area, downtown Anchorage, immedintely following 1964 earthquake . . . . . 8

5. Oblique aerial photograph of Fourch Avenue slide area, $1979 \ldots \ldots \ldots \ldots$

6. Map shewing localion of slope-indicator casings, Fourth Avenue slide zone . . . . . . . . . . 10

7. Map showing location of slope-indicator casings, L Street slide zone . . . . . . . . . . . . . . 11

8. Map showing location ol slope-indicalor casings, Turnagain Heights slide zone . . . . . . . . . 12

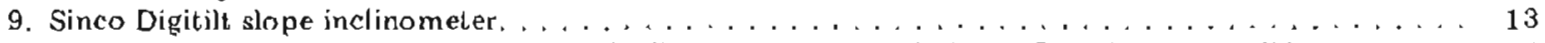

10. Borehole logs for siles al and near slope inclinometer siles, A Serjes 1, Fourth Avenue slide zone .... 14

11. Borehule logs for siles al and near slope inclinomeler site A1005, A Series 2, Fourch Avenue

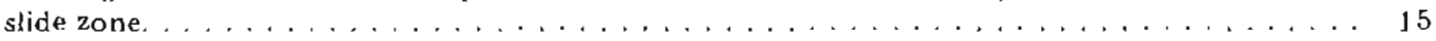

12. Borehole logs for siles at or near slope inclinometer site A112, A Series 3, Fourth Avenue

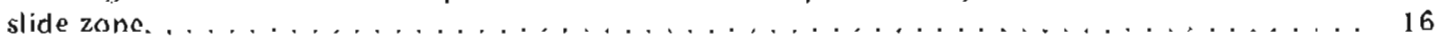

13. Borehole logs for sites at or near slope inclinomeler site B L 1 , B Series 1, L Streel slide zone ..... 17

14. Borehole logs for sites at or near slope inclinometer siles B 1 and B4, B Series 2, L Street slide zone .. 18

15. Borehole logs for sites al or near slope inclinometer site C134, C Series 1, Turnagain Heights slide zone. . . . . . . . . . . . . . . . . . . . . . . . . . . 19

16. Borehole logs for siles at or near slope inclinometer site CB3 and CB5, C Serias 2, Turnagain

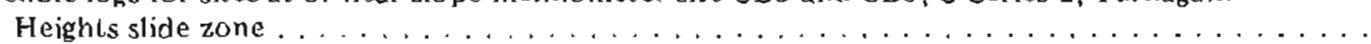

\section{TABLES}

Table $\quad$ L. Slatus of slope inclinometer casing in Anchorage, December $1980 \ldots \ldots \ldots$

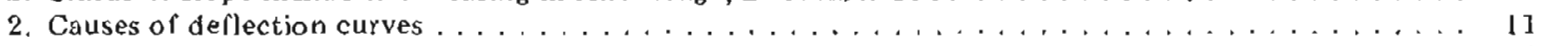

3. Index lo symbols on figures $10-16 \operatorname{logs}$ and composite profiles . . . . . . . . . . . . 12 


\title{
INCLINOMETER STRAIN ANALYSES OF ANCHORAGE LANDSLIDES, 1965-80
}

\author{
By Randall $\mathbf{G}$. Upák $\mathrm{e}^{1}$
}

\section{ABSTRACT}

Several large destructive landsliues occurred in Anchorage, Alaska when sensitive and liquefiable facies within the Boollegger Cove Formation failed during the 1964 Prince William Sound Earthquake.

Twenty-five slope-inclinometer casings were installed in and around the three largest landslides immediately after the earthquake, and four additional casings were installed in 1977 and 1978.

Fourteen of the 29 casings were relocated and resurveyed in 1979. A comparison of new dala with previous records and with detailed engincering geologic stratigraphy indicates that negligible strain has occurred in the vicinity of the Turnagain Heights and $L$ Streel slides; however, in the 'buttress area' of the Fourth Avenue slidc, several rones of up to 3 in. deflection occurred priar to 1977 .

Although potentially unstable soils remain, no significant strain has occurred in these three major slide areas.

\section{INTRODUCTION}

From its beginnings as a construction camp for the Alaska Rallroad jusl prior to Worid War I, Anchorage (then Ship Creek) has grown markedly, despite the presence of natural phenomena such as volcanic erup. tions, floods, high winds, and avalanches.

The occurrence of one of these hazards, the Prince William Sound Earthquake of March 27, 1964---also known as the Good Friday Earthquake-..remains Anchorage's most renowned catastrophic event. The earthquake was manifested by a variety of effects, including massive ground failure at several locations al or near bluffs in the city.

1 am studying the soil strength and mobility polen. tial of these slide zones to determine the likelihood of future failure of the same or adjacent soils masses, hoth with and without another major earthquake.

\section{GEOLOGIC SETTING}

Anchorage is situated on a broad alluvial plain that slopes gently from the Chugach Mountains on the east to Cook Inlet on the west and south (fig. 1). The plain is truncated by bluffs up to $130 \mathrm{ft}$ high along both Cook Inlet and major streams flowing to the inkt from the

\footnotetext{
${ }^{1}$ Dggs geologist, A nchorage, Alaska 99501.
}

mountains. 'The bluffs expose a complex of unconsolidated sediments that are often at or near saturation. These free faces, coupled with certain subsurface geologic conditions, contribute to the inherent instability of the land adjacent to the blurfs. This is compounded by the geologic setting: Anchorage is located within an active tectonic cramework (fig. 1). Earthquakes are frequently feit. There are active fault traces in nearby Quaternary deposits.

Anchorage is siluated on the eastern margin of the Cook Inlet forearc basin. This tectonic basin is bounded on the northwest by the Bruin Bay-Castle Mountain fault system and on the southeast by the Border Ranges Pault system (fig. 1). Scismicity occurs along bolh fault systems and along the underlying Benioff zone. which is caused by subduction of the Pacitic plate beneath Alaska.

Although most selsmic events occur along this zone of underthrusting (Stephens and others, 1980), the likelihood of near-surface events associated with the fault system is significant. Seismic events related to the Castle Mountain system are generally of low magnitude ( $M=3.0$ to 4.5 ) and shallow, even though the potentlal for larger magnitudes $(>6.0$ ) is quite real (John Lahr. pers. commun., 1980).

The Border Ranges fault system is more of an enigma. No evidence has been found to document that fault traces truncated late Quaternary deposits along the Chugach Mountains east to northeast of Anchorage. Unpublished work of other investigators provide evidence for low-magnitude Holocene seismicity along the Border Ranges fault, but source of the seismicity remains questionable.

Bedrock in the Anchorage area consists of Tertiary clastic sedimentary rocks and older metamorphic rocks of the Chugach Mountains, and is generally 325 to $650 \mathrm{ft}$ below the surface. Engineering and design criteria are focused on the thick unconsolidated sedimentary sequence that was deposited predominantly in Pleisto. cene time and partially reworked during Holocene time. The best summaries of the Quaternary gcologic history are those of Milter and Dobrovolny (1959), Karlstrom (1964), and Schmoll and Dobrovolny (1972).

Upper Cook Inlet has had a varied Quaternary history. The geologic record---produced by the interplay of fuctuations in sea level, advances and retreats of adjacent mountain glaciers, and tectonic subsidence and uplift...is indeed complex, and details of this history, 


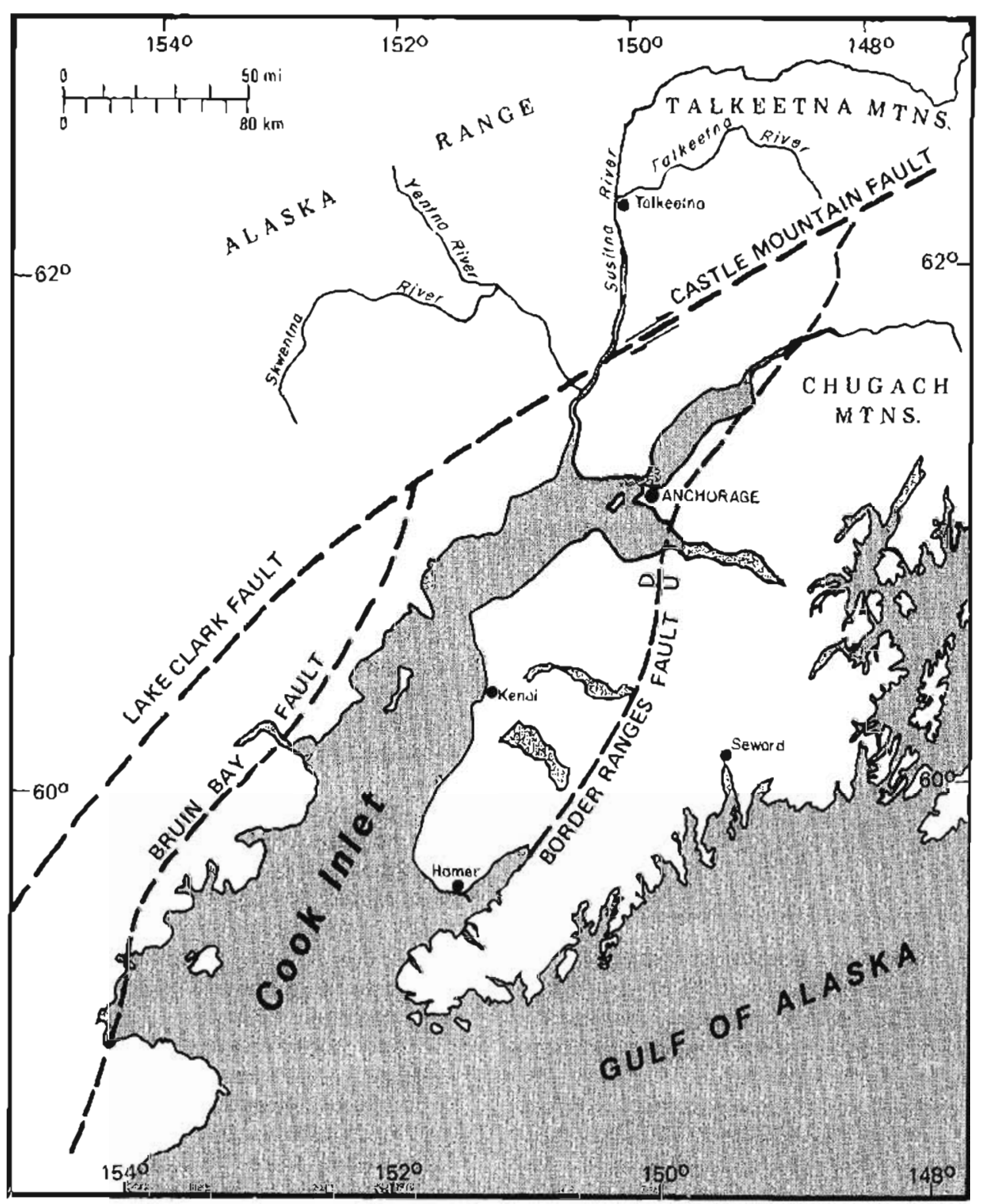

Figure 1. Tectonic setting of Anchorage

particularly the time trames and extents of specific erosional and depositional episodes, are controversial.

The Bootlegger Cove Formation, ${ }^{2}$ which was responsible for the extensive landstides of 1964, consists of stratified clastic sediments ranging from clay to boulders, with thicknesses varying from 30 to $75 \mathrm{~m}$. Microlossil evidence supports marine deposition, although a glacially restricted, brackish environment cannot be disregarded. Radiocarbon dates obtained by Schmoll and others (1972) indicate a late Pleistocene age $(>14,000$ yr B.P.) for the upper part of the formation.

\footnotetext{
2 Formerly termod 'Bootleger Cove Clay.' this geologic unit has been renamed a formation by Updike and Carpenter. 1983 (in press).
}

The Bootlegger Cove Formation is generally overlain by 3 to $15 \mathrm{~m}$ of stratified outwash sands and gravels de. posited during the Naplowne Glaciation. It is underlain by glacial and glaciofluvial silts, sands, and gravels.

\section{MECHANICS OF GROUND FAILURE IN THE BOOTLEGGER COVE FORMATION}

Numerous old landslides along bluffs and stream valleys in the Anchorage area can often be attributed to instability of the Bootlegger Cove Formation, which underlies much of the western part of the city. The potential for catastrophic failures of the formation was recognized as early as 1959 by Miller and Dob- 
rovolny,

Besides stability problems associaled with the Bootlegger Cove Formation during the 1964 earthquake, the extreme ground motion and long duration of shaking caused mumerous subsidence and gravity-fall failures. More importantly, the induced cyclic shear stresses that devcloped within the Bootlegger Cove Formation caused lanoslides near bluffs at several locations in tle city.

Two failure mechanisms were pursued rigorously in the literature: a) liquefaction of silts and sands (Seed, 1968, 1976; Seed and Wilson, 1967; Shannon and Wilson, 1964) and b) collapse of sensitive silty clays (Long and George, 1966; Kerr and Drew, 1965, 1968; Hansen, 1965). The 1964 Anchorage landslides have become case histories for both lypes of failure mecha. nisms, but no agreement has been reached as to which was primarily responsible or which should be of preeminent concern in the future.

\section{LIQUEFACTION}

During an earthquake, soil is subjected to a series of shear stresses that randomly vary in magnitude. If a saturated, cohesionless soil-...ideally a well-sorted sand... is subjected to seismically induced cyclic loading, the soil structure tends to become compacted and the resultant stress is then transferred to the pore water. In response, the soil structure rebounds, volume remains constant, and pore-water pressure increases. When the pore pressure equals the confining pressure, a state of 'initial liquefaction' (Seed, 1976) is reached and, if cyclic stress continues, the resulting strain produccs 'cyclic mobility' (Casagrande, 1976). Depending on these factors--sand density, confining pressures, and magnitude of the stress cycles--. Lhe soil may be mobilized to unlimited deformation or may encounter only limited strain before dilating to a siable condition. If liquefaction occurs at or near the ground surface (as in Niigata, Japan, in 1965), considerable bearing strength is lost and sand flows result. If a quasi-rigid sequence of soils overlies the liquefied sand, the overying sequence may be laterally displaced for the duration of the cyclic loading and translalional block slides can occur. This mechanism has been proposed for the Turnagain Heights and L Street slides (Seed, 1976).

\section{COLLAPSE OF SENSITIVE SOIL STRUCTURES}

Certain layers with in the Bootlegger Cove Formation are composed of silty clays, which were probably deposited in brackisli to saline waters. This deposition is conducive to the formation of an open, flocculated tramework of soil particles--.in short, a structure that has acquired some degree of internal strength by ionic bonding and precipitate cementation between its intersecting particles. Under high shear stresses, the nocculated structure collapses with an attendant decrease in volume, As a result, if the drainage of pore water is too slow, as in a low-permeability' confined zone within the Bootlegger Cove Formation, effective stresses in the zone of collapse approach zero, causing lateral now and planar gliding. This lailure also affects overlying units, and block movement occurs along numerous secondary shear planes.

The soil is considered sensitive if, on remolding, its strength $^{3}$ is significantly less than what it was in the undisturbed stale. Although the inilial movement may closely resemble liquefaction along deep, cohesionless horizons, sensitive-clay failures would likely continue after cessation of the cyclic shear stresses because of the continucd loss of shear strength,

The most apparent source of local sensitivity in the Bootlegger Cove Formation is the Quaternary fluctuations of sea level and the associated leaching of salt bonds from the flocculated structure. Mitchell (1960) suggested that thixotropic hardening may atso affect sensitivity in remolded zones by reorganizing the balance of the interparticle forces, which would tend to floc. culate the particles in a newly escablished water-cation structure. The limited shear strains encounlered during prior seismic events then remold the silty clays along failure planes and serve to expand the sensitive zone vertically.

In fact, where both liquefiable silly sands and sensitive clays occur at or above sea level and seismic loading is high enough lo trigger mobilization, both stratigraphic units could fail, as was the case in the Turnagain Heights slide, described below.

\section{THE 1964 LANDSLIDES}

Among the numerous ground failures that occurred in Anchorage during the 1964 earthquake were six major slides: a) Tumagain Heights, b) L Street, c) Fourth Avenue, d) Native Hospital, e) Government Hill School. and Cherry Hill (fig. 2).

Although each slide had its own distinctive volume, vertical and horizontal displacement, and mechanics of movement, all tailures were characterized by lowstrength soils at or near sea level and by extensive Cree faces that fronted on either Knik Arm or Ship Creek (Shannon and Wilson, 1964: Hansen, 1965).

Of the six slides, three...Turnagain Heights, L Street, and Fourth Avenue...had severe impact on commercial and residential development (figs. 3-5). Each was intensely studied shortly after the earthquake and, al. though experiments in soil stabilization (electro osmosis and explosives) were conducted, only the Fourth Avenue slide was actually buttressed; the others were simply backfilled and graded.

\footnotetext{
${ }^{3}$ Relative strength is usually expressed as a ratio beween the undisturbed shear strangth and the remolded shear strength.
} 


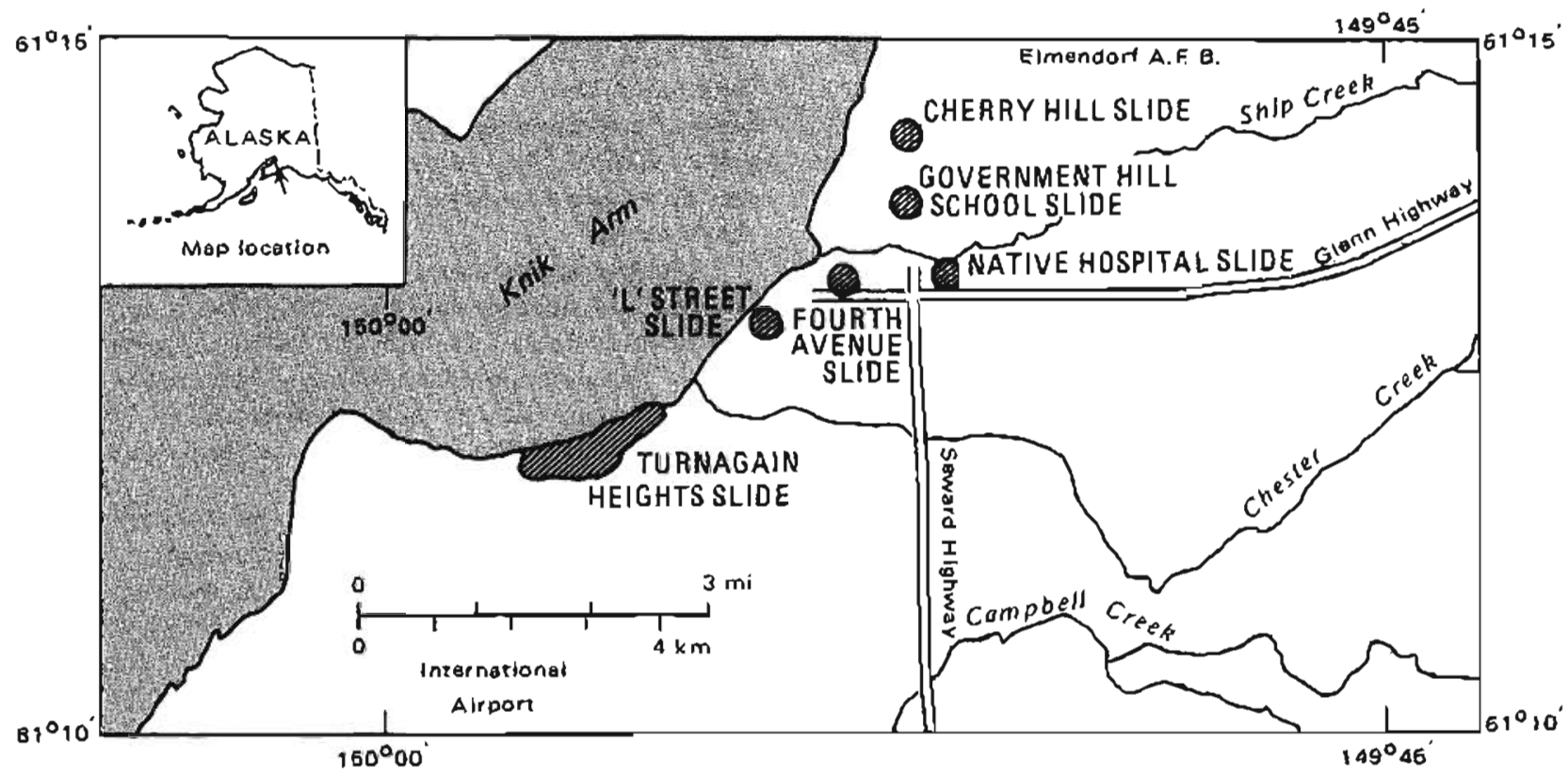

Figure 2. Map of the Anchorage area showing the approximate locations of the 1964 seismic-induced landslides.

\section{INCLINOMETER INSTALLATIONS}

Post-1964 earthquake geoteclinical studies were conducted primarily by the U.S. Army Corps of Enginecrs in conjunction with both Shannon and Wilson, Inc., and ACLW Consultant Engineers. Numerous borings were made to collect undisturbed samples for laboralory testing, to confluct in-situ soil tests, and lo determine piezometric conditions.

At 25 siles, 3-in.-dia slope inclinometer casings were installed in the boreholes. These specially designed aluminum casings had four machined tracks uniformly spaced at 90-degree intervals. When a sensor was lowered down the casing along the tracks, the orientation of the casing with respect lo depth was recorded. The approximate geographic locations of these casings were re. ported by Shannon and Wilson (1964).

Four additional casings were instalied, two adjacent to the Fourth Avenue slide by DOWL Engineers for the Anchorage Municipality in 1977 and two the next year for the USGS in Lynn Ary Park, adjacent to the Tumagain Heights slide area. The approximate positions of the 29 installation sites are given in figures 6.8.

During 1978-1979, I assembled all known docu. ments related to the inclinometer casings and found that within the first 14 months of inslullation, eight of the sites constructed in 1964 had been lost to grading, burial by fill, or new construction. I then field-checked the sites and found only 10 of the original 25 casings (table 1). Three of these were inaccessible and considered unreliable because post 1965 construction had disrupted the casings. Thus, of 29 total casings, only 11 ...seven of the original ones and all four new installa. tions-..could be reoccupied for this study.

\section{INSTRUMENTS AND PROCEDURES}

Each of the 11 inclinometer sites was surveyed with a Sinco Digitilt model C370 inclinometer (instrument 50306). This instrument (fig. 9) has a sensitivity of one part in 10,000 or about $10 \mathrm{sec}$ of are at $0^{\circ}$ inclination. The specification error of measurement in a $100-\mathrm{fl}$-deep hole should be less than $10.2 \mathrm{in}$. The sensor, containing two servo-accelerometers mounted with their sensitive axes at right angles, was inserted into the casing and lowered along the machined grooves on spring-loaded wheels to the base of the hole by an electrical cable connected to a digital indicator at the surface. The sensug was orienled to follow the casing tracks nearest to the north-south plane. After allowing $10 \mathrm{~min}$ for temperature equilibration, the sensor was raised at $2-\mathrm{ft}$ intervals from the base of the hole and readings were recorded at each interval for both the north-south and east-west axes. When the sensor reached the top of the casing it was removed, rotated 180 degrees, and reinserted to the bottom of the hole for a second series of measurements. The numbers recorded by this procedure are equal to 2 sine $\theta$, where $\theta$ equals the inclination (in degrees) of the sensor from vertical $\left(0^{\circ}\right)$. Algebraic signs denote inclination toward the north $(+)$ or south $(-)$, east $(+)$ or west ( $)$. The algebraic difference between the two sets of readings ( $\triangle N S$ and $\Delta E W$ ) were used to compute casing inclination, for example, $\theta$ in the north-south plane:

$$
\theta \text { (degrees) }=\sin ^{-1} \frac{\Delta N S}{4 \times 10^{4}}
$$




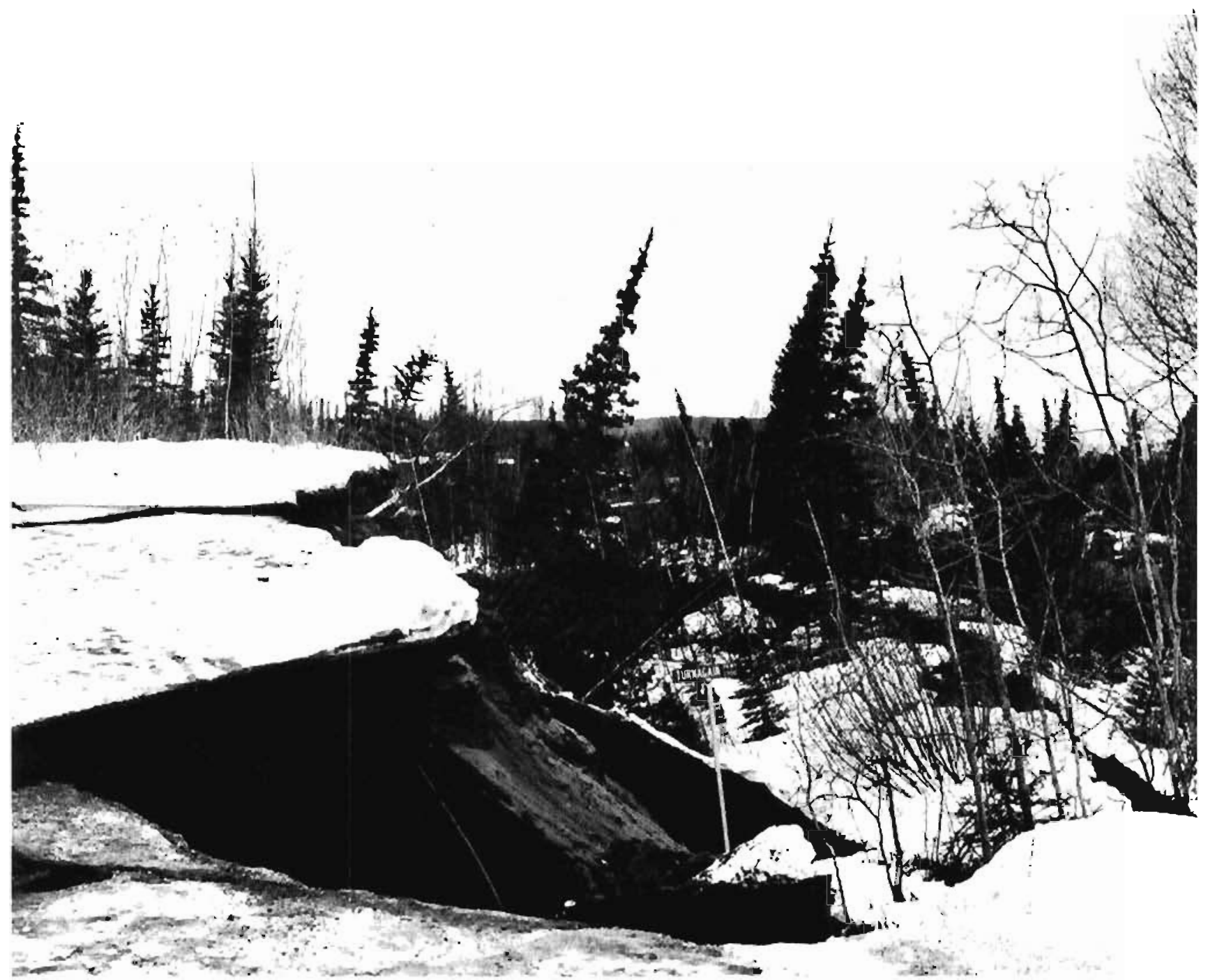

Figure 3. Tumagain Heights area immediately following 1964 earthquake Intersection of Turnagain Parkway and McCollie Avenue, looking west. Location is wilhin $200 \mathrm{~m}$ of inclinometer siles C1B, CB5, and CB3. (Photograph from NOAA-EDIS files.)

For any depth the north-south lateral deflection of the top of the sensor wilh respect to the bottom of the serusor (24-in. spacing) was computed by:

$$
\begin{aligned}
\text { Deffection (in.) } & =24 \sin \theta \\
& =24\left(\frac{\Delta N S}{4 \times 10^{4}}\right) \\
& =6 \times 10^{-4} \times \Delta N S
\end{aligned}
$$

'This same procedure was followed for easl-west deffeclion by substituting $\Delta \mathrm{EW}$ for $\triangle N S$, and the computed results were denoled by deflection (DEFL). When plotted graphically against depth, the cumulative sum of DEFL gave an accurate representation of the configuration of the casing in the north-south and east-west plancs. In addition, the data can be compared to pre. vious data sets to determine the past behavior of the casing. Appendix A shows the nortly-south and east-west profiles of the 11 casings as represented by the data acquired in this survey.

\section{COMPARISON WITH PREVIOUS DATA SETS}

During the first few weeks following the installation of the inclinometer casings in 1964, several sets of readings were taken, apparently because of concern over continued strain in the slide zones. The casings not lost to reconstruction were measured again in Jume 1965 and, except for readings on two casings in the Fourth Avenue slide area, were not surveyed again. Fortunately, 
Table 1. Stotus of slope inclinometer cosings, December 1980 .

\begin{tabular}{|c|c|c|c|c|}
\hline Hole & $\begin{array}{c}\text { Installation } \\
\text { by }\end{array}$ & $\begin{array}{l}\text { History of } \\
\text { readings }\end{array}$ & $\begin{array}{l}\text { Statis of } \\
\text { data on file }\end{array}$ & Status of hole \\
\hline $\mathrm{A} 1 \mathrm{~A}$ & ACLW for City & $1964-65$ & Initial, 1965 & Lost to mall construction \\
\hline$A 2 \mathrm{~A}$ & $"$ & $\begin{array}{l}1964 \cdot 65 \\
1977 \cdot 79\end{array}$ & All data & Intact \\
\hline A $3 \mathrm{~A}$ & 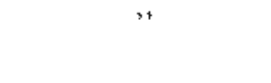 & $\begin{array}{l}1964-65 \\
1977-79\end{array}$ & All data & $"$ \\
\hline $\mathrm{A} A \mathrm{~A}$ & $"$ & $1964-65$ & $\begin{array}{l}\text { Initial, } 8 / 64 \\
1965\end{array}$ & Lost to new construction \\
\hline A5A & ", & $\begin{array}{l}1964-65 \\
1979\end{array}$ & $"$ & Intact \\
\hline A1065 & Shannon \& Wilson & $1964-65$ & $"$ & Present but inaccessible \\
\hline $\mathrm{B}-1$ & ACLW for City & $\begin{array}{l}1964-65 \\
1979\end{array}$ & $"$ & Intact \\
\hline$B-2$ & $"$ & $1964-65$ & " & $\begin{array}{l}\text { Lost to grading and fill } \\
\text { gfter } 1965\end{array}$ \\
\hline B-3 & $"$ & $"$ & $"$ & $"$ \\
\hline$B=4$ & ACLW for City & $1964-79$ & Initial, $7 / 64$ & Intact \\
\hline B. 101 & Shannon \& Wilson & $\begin{array}{l}1964-65 \\
1979\end{array}$ & $\begin{array}{l}8 / 64(\text { (nitial) } \\
1965\end{array}$ & " \\
\hline$B-106$ & $"$ & 1964 & $7 / 64$ & $\begin{array}{l}\text { Lost in } 1964 \text {; buried by } \\
\text { fitl }\end{array}$ \\
\hline B-1 I3 & $"+$ & $1964 \cdot 65$ & $\begin{array}{l}\text { Initial, } 8 / 64 . \\
6 / 65\end{array}$ & $\begin{array}{l}\text { Lost to construetion of } \\
\text { I. St building }\end{array}$ \\
\hline $\mathrm{C} 1 \mathrm{~B}$ & ACLW for City & 1964 & Initial, mid-1964 & Lost to grading, 1964 \\
\hline $\mathrm{G}-100$ & Shannon \& Wilson & $1964 \cdot 65$ & $\begin{array}{l}\text { Initial, mid-1964 } \\
-65\end{array}$ & Lost after 1965 \\
\hline
\end{tabular}

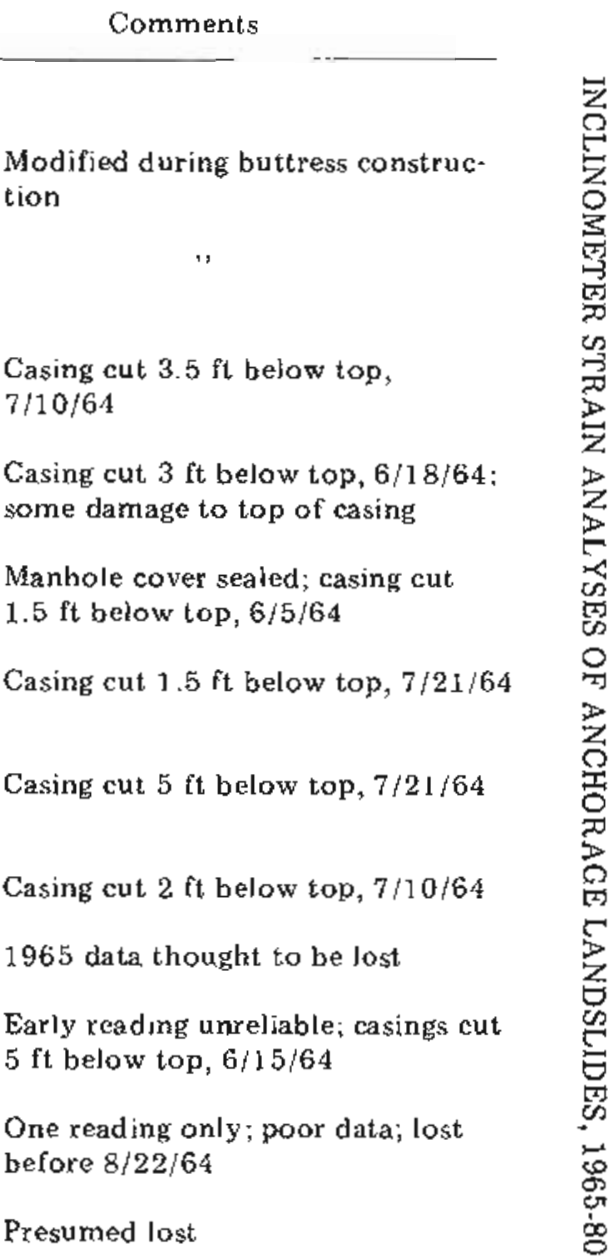

Regard data as poor, casing cut $5 \mathrm{ft}$ below top, 7/2,1/64

Very close to scarp; casing cut $3 \mathrm{ft}$ below top, 6/5/64 
Lost after 1965

Lost to sewer installa. tion, 1964

Initial, $8 / 64$, 6/4/65

Located but closed $3 \mathrm{ft}$

below surface

Initial, 8/64

Lost to grading, 1965 1965

1979

$1979 \cdot 80$ Located but sealed below
surface unrecoverable

lntact but closed at $44 \mathrm{ft}$; unrecoverable

\section{Lost to sewer instal ha.} tion, 1964

Closed with rubbish $10 \mathrm{ft}$ below surface; unrecoverable

$1977 \cdot 79$

New hole, 1979

New hole, $1979-80$
LnLact

Open to $52 \mathrm{ft}$

Open to $54 \mathrm{ft}$; reopened to $70 \mathrm{ft}, 1980$
Poor reliability

Lost before reading history developed

Errors between readings

Short data period

7/20/64 data computed by S\&W not accurace; problems with casing top in 1964-65

No problems to $151 \mathrm{ft}$ in 1965 ; top of casing loose, 1965; lost in recovery attempt, 1880

Casing cut $2 \mathrm{ft}$ below top on $6 / 5 / 64$

Lost to casing obstruction

Small-dia casing; slurry filling to 53-fi depth

Large-dia casing, slurry to $55-\mathrm{ft}$ depth cleared in 1980 


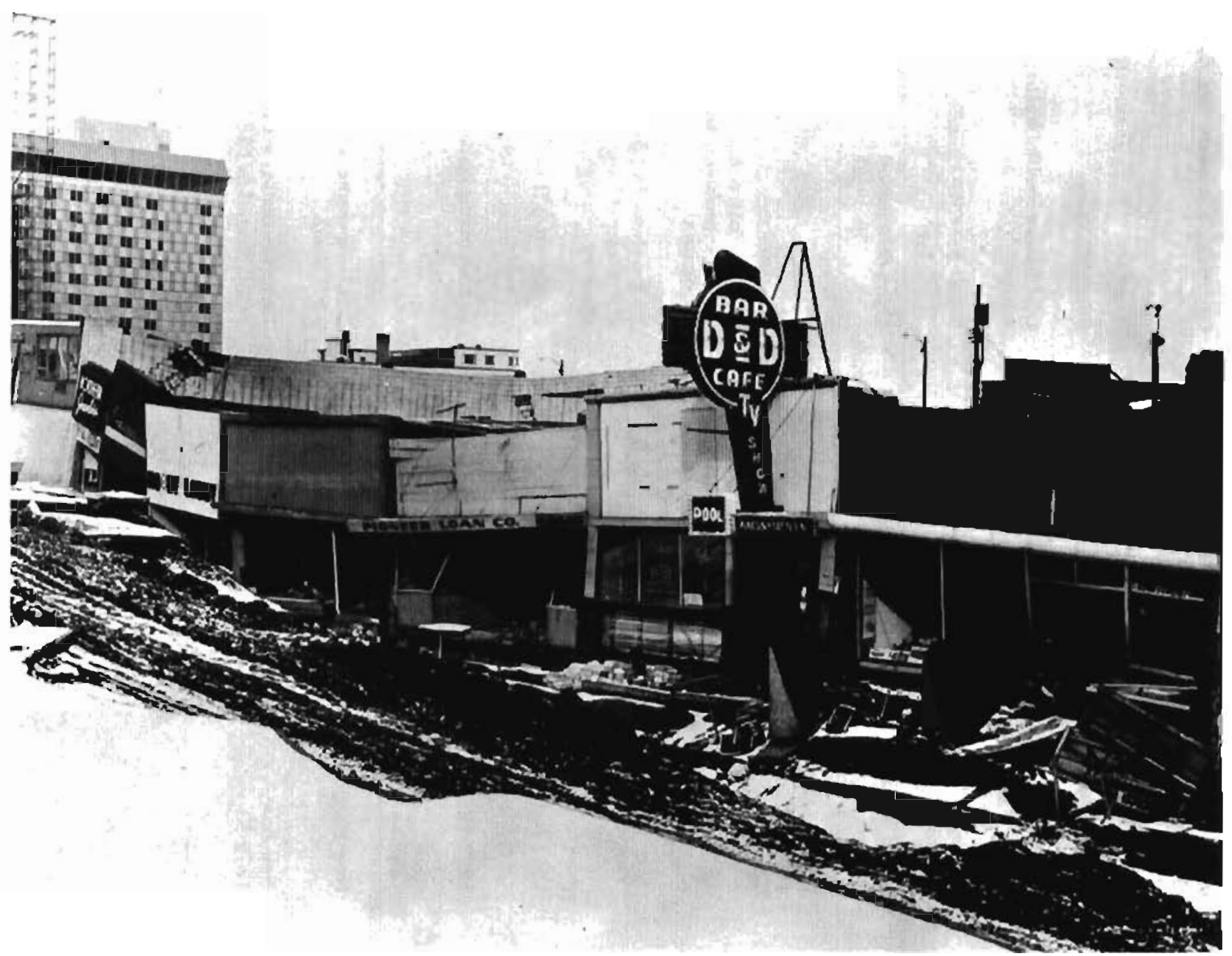

Figure 1, Fourth $A$ vente slide area, downtown Anchorage, immedalely following 196 s earthquaks. View is north side of Fourti Avenue. (Pholograph from NOAA-EDIS files.)

the U.S. Army Corp of Engineers retained records of these measurements.

The 1964lisis measurements were made wilh a 20-in.long Sinco wries $220 \mathrm{~B}$ inclinomeler, whereas post-1975 readings were made with the Digitilt C370 inclinometer, which is $A$ in. longer. $A s$ a result, procedures for the older instrument specily measurements at different intervals than those specined for the (:3i:0. In addition, lhe former inslluments have a specified accuracy to three decimal places, whereas the Digitilt records (u) four. However, bolh instruments record data that are equated to the inclination angle of the instrumenl al a given depth and, cven though the depth interval may be different, each records the orientation of lhe casing in three-dimensional space relative to the vertical.
'To directly compare the various dala sets, the new data were rounded from four to three decimal places, the original (1964.65) deph intervals were retainerl, and each site was evaluated with respect to history of read. ings, problems encountered in takings those readings, modifications to the casings, and unusual variations nmong the data sels that could indicale less confidenc" in a given set. When possible, three of the early data sets were uscd for comparison: a) the earliest reliable set afler imblallation, used as the initial readings for this sludy, b) the latest reliable 1964 set, generally recorded in late summer, and c) the 1965 set on the casings that were still intact. Where the llew data values are at different depths than those of the 1964-65 sets, the new values were inkerpolated to the earlier interval depths. For example, to compare a new value with an earlier 


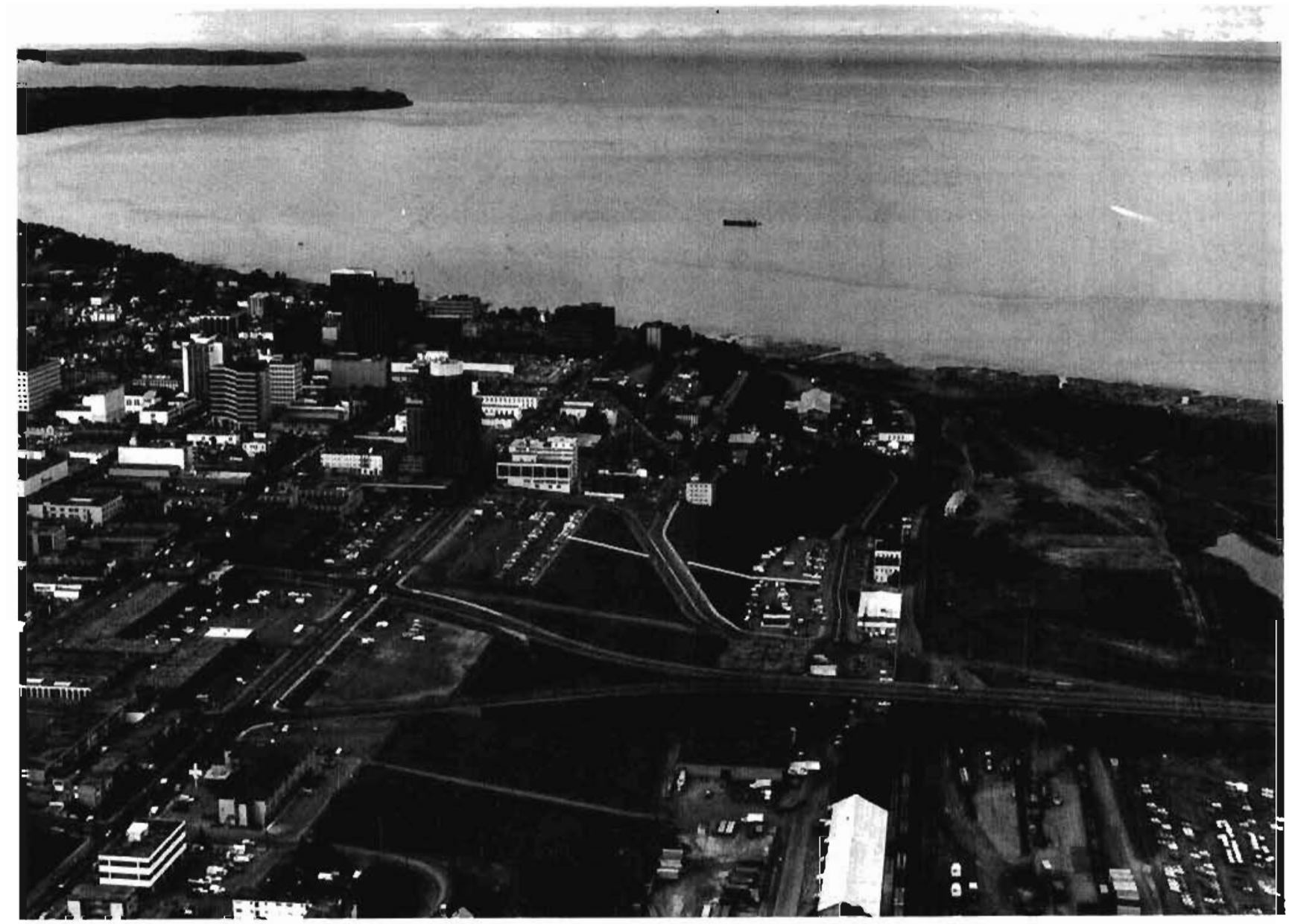

Figure S Oblique aerial photograph of the Fourth Avenue Slide area, 1979. The Fourlh Avenue buttress, constructed after the 1964 earthquake, in cenler. (Pholograph by R.G Updike, 1979.)

depth of $7.5 \mathrm{ft}$, interpolation was made between the 6 . and \&-fl values of the new data. The author described this technique to D. Shoup, senior electronics engineer, Slope Indicator Company, who confirmed the viability of the technique (writlen commun., 1980). The older data sets are in Appendix $B$, along with the interpolated new values.

Deflection from the inilial readings for selected depths was plotted to demonstrate postinstallation movement of the casing. Plots for each of the casings are given in Appendix $\mathrm{C}$.

Three general causes can be identified to account for divergences from the initial line: a) the casing moved in the borehole after the initial reading, with little or no corresponding movement of the surrounding soils. b) instrument measurement error was introduced and maintained throughoul the readings, and c) actual strain of the surrounding soils occurred after the initial read. ings.

'The actual cause of the variation can generally be delermined by comparing the deflection profiles of the casing. For the lirst case, each of the postinitial deflection profiles would be in close agreement with or al most would show only minor variation over the length of the casings. The second case would not show a single spurious deflection profile but would be in close agree. ment with the other profiles for that casing. In the third case, either the deflection profile would consistently change from one sel to the next or an abrupt change would registey on subsequent readings.

However, the Digitilt inclinometer is accurate to within $\pm 0.2 \mathrm{in}$. per $100 \mathrm{ft}$, and incremental deflections within instrument accuracy cannol be confidently ascribed to actual casing displacement. The horizontal scale used in plots of Appendix $\mathrm{C}$ is actual deflection from the inilial calibration profile.

On the basis of the above constraints, only two casings, $\triangle 2 \mathrm{~A}$ and A3A, show post-1964 strain. Moreover, both showed strain in both the north-south and east-west directions. Six other casings may show post- 


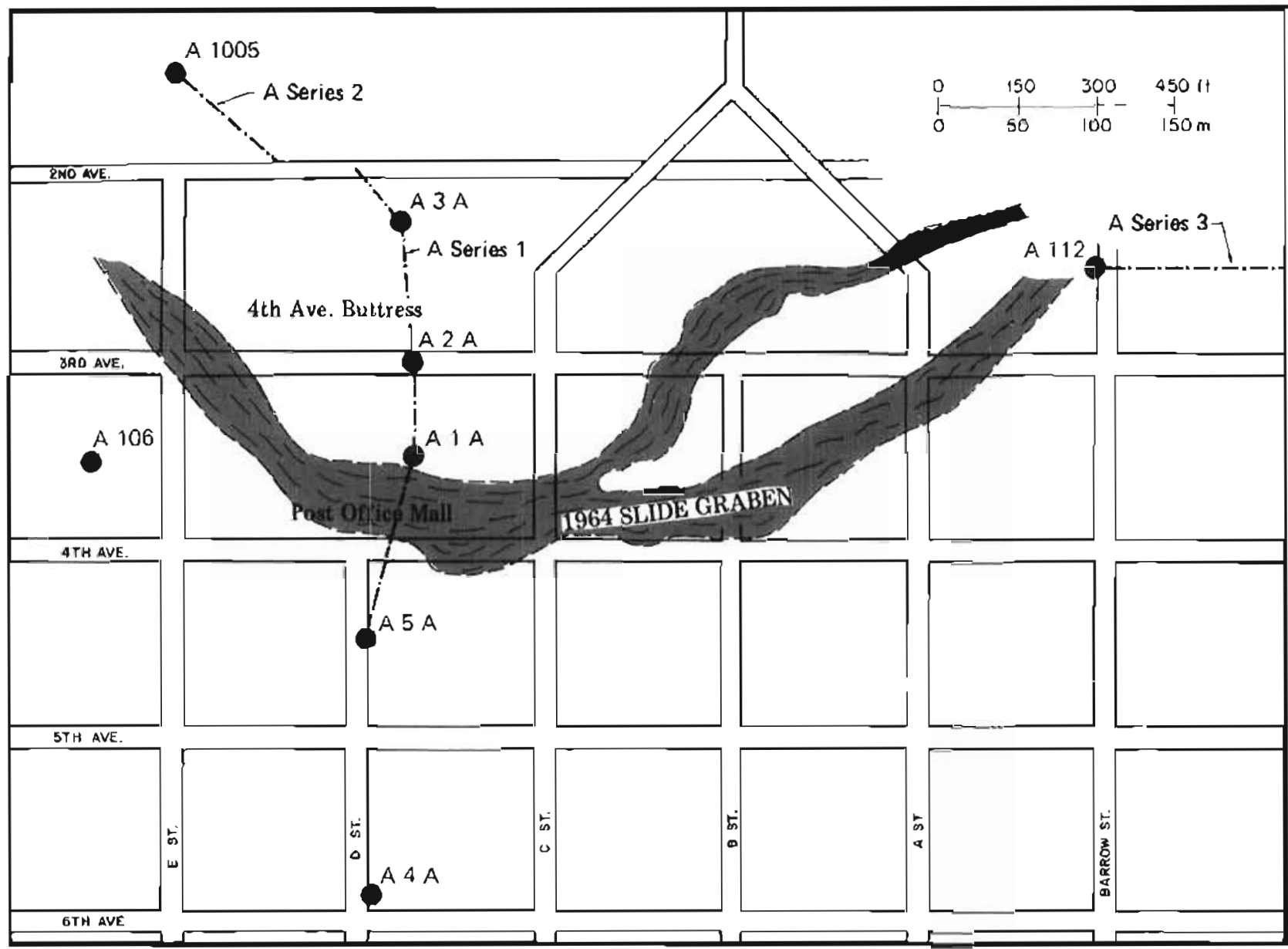

Figure 6 Map showing the location of slaue-indicator casings associated wich the Fourth Avenue slicle. Lateral dis placement was primarily north of the indicated graben, with movement toward the north. Crosssection lines for rigures $10-12$ are indicated by the dashed series lines.

installation strain. Table 2 assesses the deflection curves ( $A$ ppendix $C$ ). Although the early loss of mally sites precluded measurement of post-1965 behavior, there are cnough siles left in and around the Fourth Avenue slide area and west of the $L$ Street slide to draw the following conclusions.

\section{CORRELATION OF DATA WITH SUBSURFACE GEOLOGY}

The Bootlegger Cove Formation is composed of at least seven geologic facies (Updike and Carpcizler, 1983; Updike, 1983\}. All may not occur at a given locality, and both thickness and stratigraphic position will vary laterally. Also, each facies has its own suile of engineering chancteristics (table 3). Within the range of characteristics for facies $F$. IV (the most $\mathrm{rom}$. mon), subtleties that may cventually necessitate a revision of the defined-facies suite have repealedly emerg. ed; Lhese variations are termed 'subracies' (table 3 ).
The seven engineering gcologic facies of the Bootlegger Cove fiormation are mappable in three dimensions. 'l'h is lias immediatc value to the engineer who is concerned aboul subsurface soil conditions at a given locality and provides geologisls with a better under. standing of the Quaternary history of the region.

Five lacies are collesive, lwo are not. The latter (F.VI and F.VIII) are susceptible to liquefaction if other criteria are salisfied (for example, ground.water conditions, effective overburden pressure, or slate of conlinement).

Of the five cohesive units, only F.III is of significant concern because of its relatively high sensitivity (mean sensilivity ratio $=19$ ). 'The in-situ stalic shear strenglh of F.III is similar to that of the other coliesive facies, but when disturbed its strength drops markedly. The presence of facies F.III, F.VI, and F.VIl beneath the bluff areas of Anchorage intimates the polential for fajlures due to bolh liquefaction and sensilive clay.

To assess the relationship of the slope-indicator 
Table 2. Assessment of causes for deflection curves presented in Appendix $C$.

Negligible

deflection

A $106-N / S$

$A \downarrow 06 \cdot \mathrm{E} / \mathrm{W}$

Al12 - N/S

Al12-E/MI

A $1005-N / S$

$A L O 0 b-E / W$

$\mathrm{B} 101 \cdot \mathrm{N} / \mathrm{s}$

$B 101-E / W$

C130-N/S

Cl $30-\mathrm{E} / \mathrm{W}$
Postinstallation acljustment

$A+A-N / S$

$A+A-E / W$

BI $\cdot N$ IS

B2 $\cdot N / S$

B. $\cdot E / W$

Bu - N/S

$\mathrm{B} 3 \cdot \mathrm{E} / \mathrm{W}$

B4 - N/S

$B 113 \cdot N / S$

$\mathrm{BI} 13-\mathrm{E} / \mathrm{W}$

C) $00-$ N/S

$\mathrm{ClOO}-\mathrm{E} / \mathrm{W}$
Probable

soil strain

$A I A-N / S$

$A \mid A-E / W$

$\mathrm{BI} \cdot \mathrm{E} / \mathrm{W}$

$B 4-E / W$

CLB $-N / S$

CiB-E/W

C103-N/S

C103 - E/W

C109. N/S

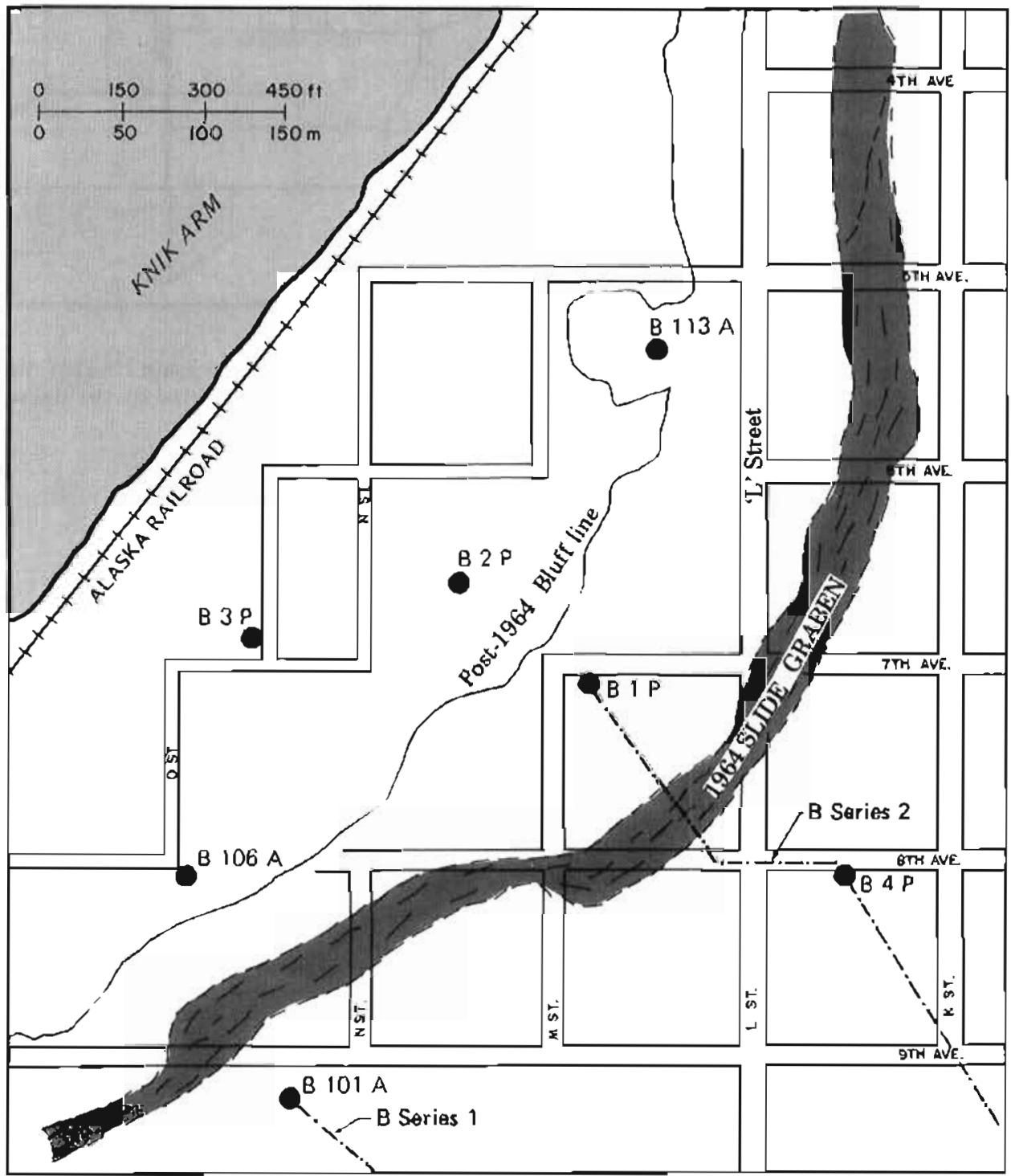

Figure 7. Map showing the location of lope-indicator casings associated with the L Street slide. The 1964 earthquake slide movement was west of the indicated graben, generally with a dominantly horizontal vector to the northwest. Cross-scclion lines for figures 13 and 14 are indicated by the dashed serjes line 


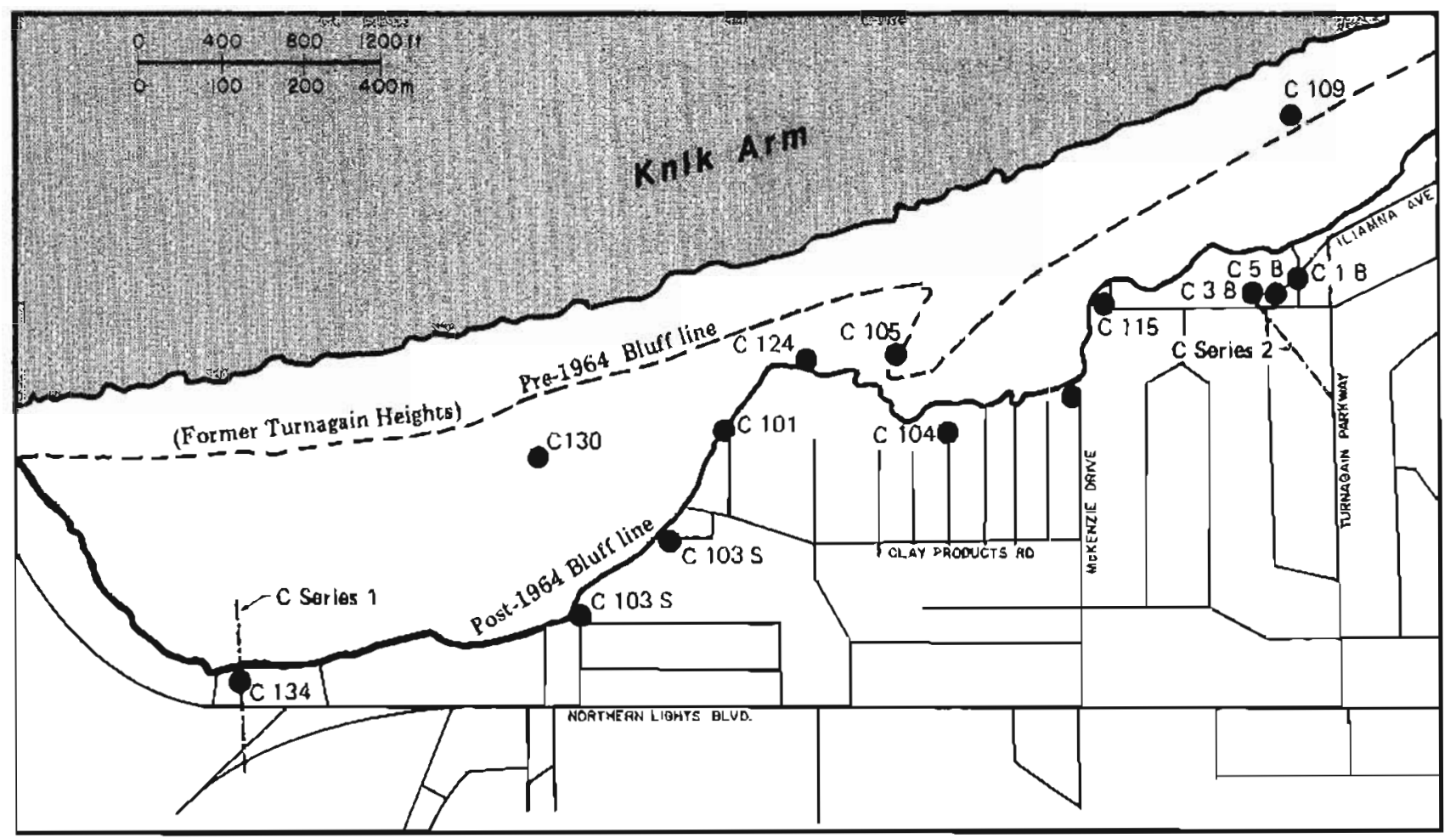

Figure 8. Map showing the location of slope-indicatar casings associated with the Turnagain Heights slide. Displacement was generally north to northwest. Cross-section lines of figures 15 and 16 are indicated by the dashed series line.

Table 3. Index to symbols used in figures 10-16. logs and composite profiles.

\section{Unified soil classificalion units}

GP. Poorly graded gravels or gravel-sand mixtures, little or no fines

SP - Poorly graded sands or gravelly sands, little or no fines

OL - Organic silts and organic silty clays of low plasticity.

\section{Engineering geologic facies of the Bootlegger Cove Formation}

I. Facies I: Clay with very minor amounts of sill and sand

II - Facies [1: Silty clay or clayey silt

III - Facies III: Silty clay or clayey silt, sensitive

IV Facies IV: Silty clay or clayey silt with thin silt and sand lenses

IVA - Subfacies F. IVA: Silty clay and clayey silt with silt and fine sand lenses

IVB - Subiacies F. IVB: Silty clay with traces of coarse sand

IVC - Subfacies F. IVC: Sandy clayey silt

$\mathrm{V}$ - Facies V: Silty clay or clayey silt with random pebbles

VI - Facies VI: Dense, silty fine sand with silt and clay layers

VII - Facies VII: Fine- to medium-grained sand with traces of silt and gravel.

Slope-indicator variations

Installation inflections

- Strain inflections, doubled where strain in both directions

_ Postinstallation obstruction. 
casings to the local stratigraphy, I reexamined geotechnical borehole logs near each of the three major slides and reinterpreted the stratigrapliy in lerms of che seven facies on the basis of the origimal logs and engineering test data.

To gain stratigraphic control on the casing and environs, boreholes drilled at or near to slope-indicator casings were selected for reexamination. The geo. technical holes werc reinterpreted according to facies, and idealized stratigraphic cross sections were constructed through the slope-indicalor. casing sites (figs. 10-16). The records of each casing were then examined to determine if casing vartalions could be attributed to soil stratigraphy. Particular allention was given to intlections in casing profiles (depth, direction, mag. nitude) and to depths at which deflections occurred (table 2).

The enpineering geologic facies and the history of

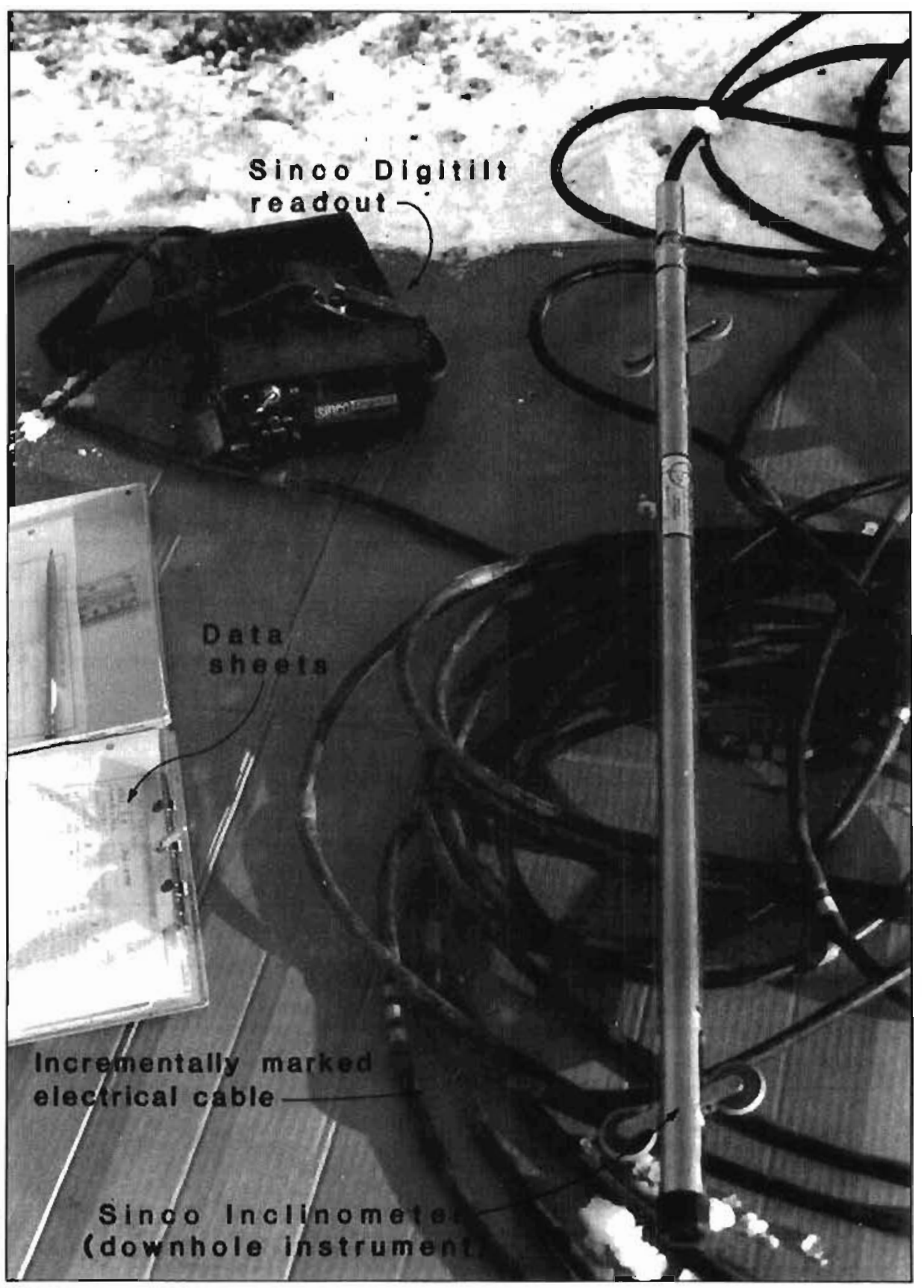

Figure 9. Sinco Digitilt slope inclinometer. (Photograph by R.G. Updike, 1980.) 


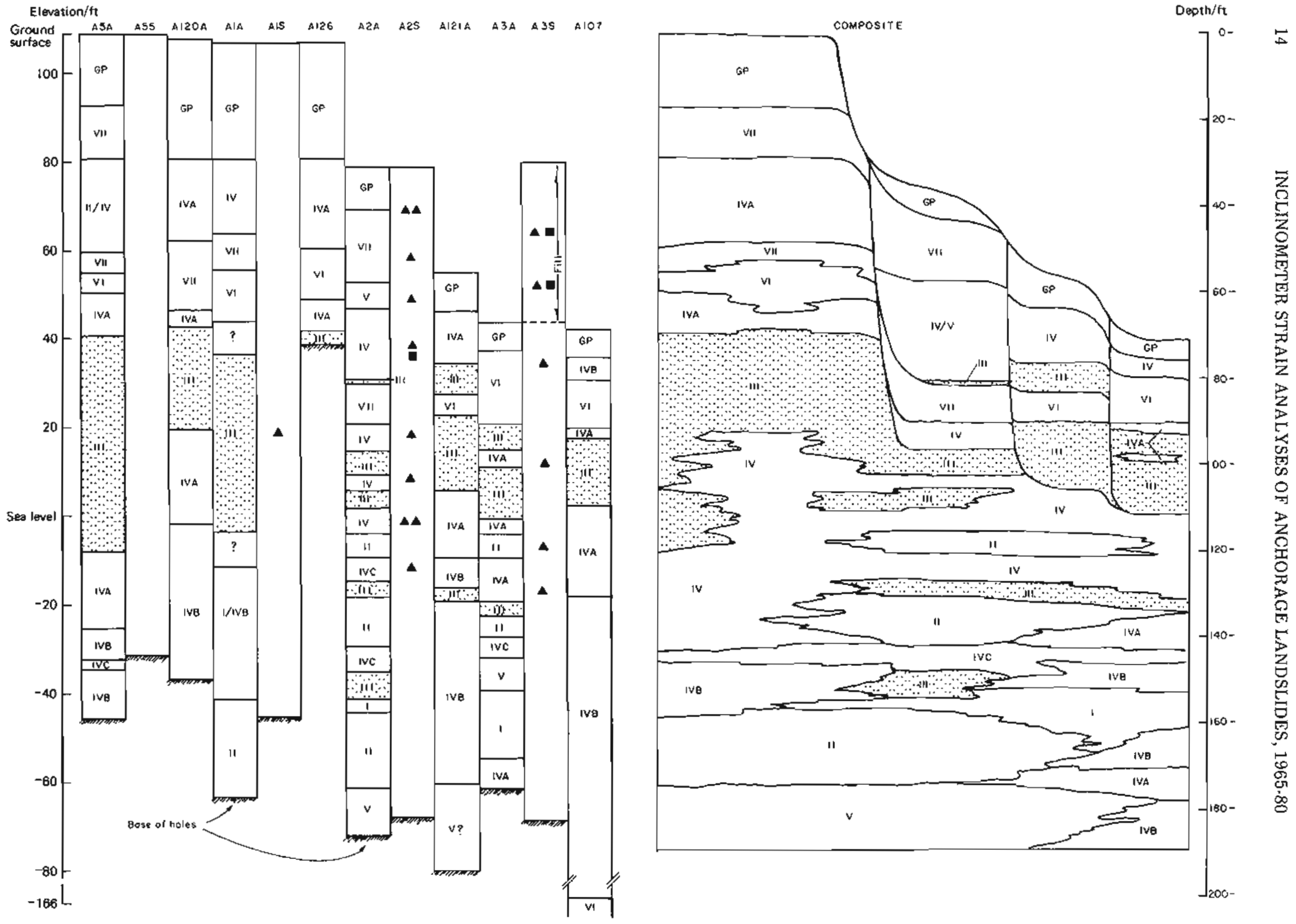

Figure 10. Borehole logs for sites at and near slope inclinometer site A series 1, Fourth A venue slide zone (fig. 6). Composite cross section at right. interpreted from borehole logs. (See table 3 for symbology.) 
the inclinometer casings may be linked in two ways: a) pacies transitions.-.for example, transition from a clayey silt (F.IV) to a sensitive silty clay (F.MI)-couid have caused minor bending or kinking of the casings during installation, or b) postinstallation strain in certain horizons may have deformed the casings. The latter strain could in turt be attributed either to continued movement along shear zones caused by the 1964 earthquake or to instability within facies that had not previously failed, Table 3 defines symbols used to denote casing irregularities; the symbols are plotted at the appropriate depths in figures 10-16.
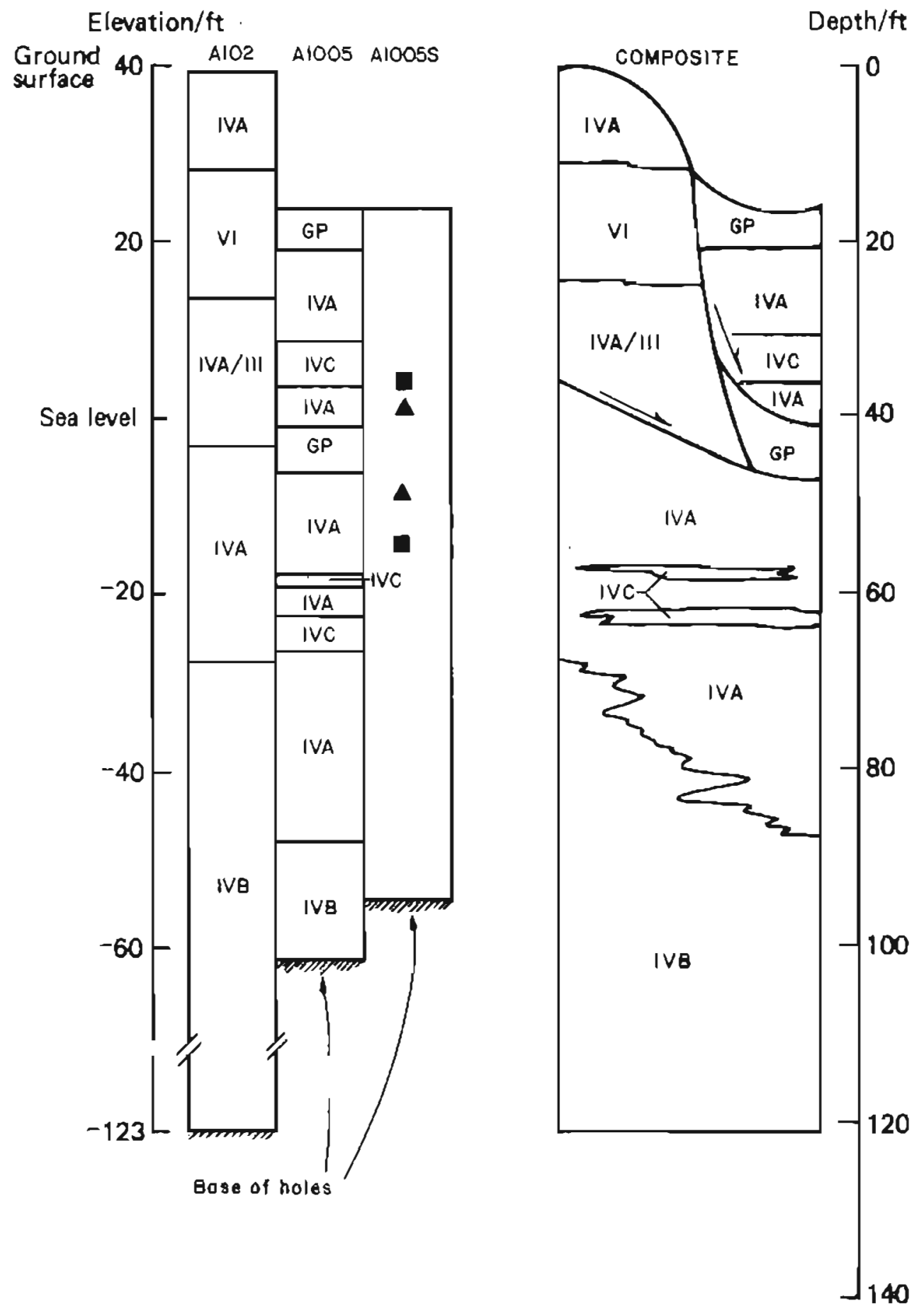

Figure 11. Borehole logs for sites at and near slope inclinometer site A1005, A serjes 2, Fourth Avenue slide zone (fig. 6). Composite cross section at right interpreted from borchole logs. (See table 8 for symbology.) 


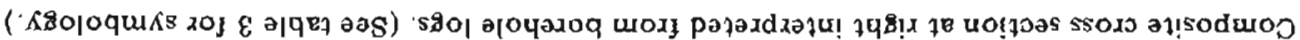

(9 'B!j) auoz ap!
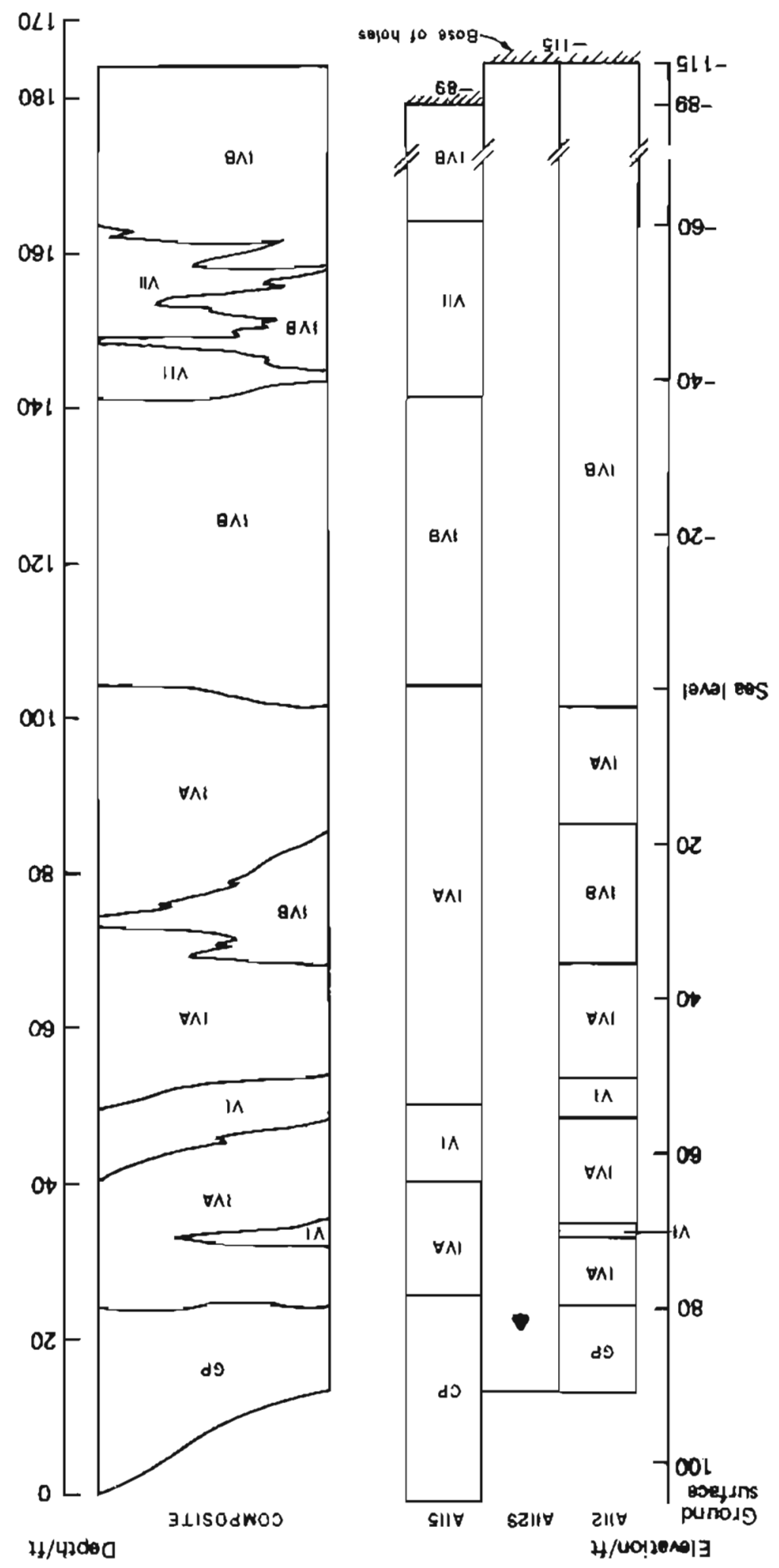

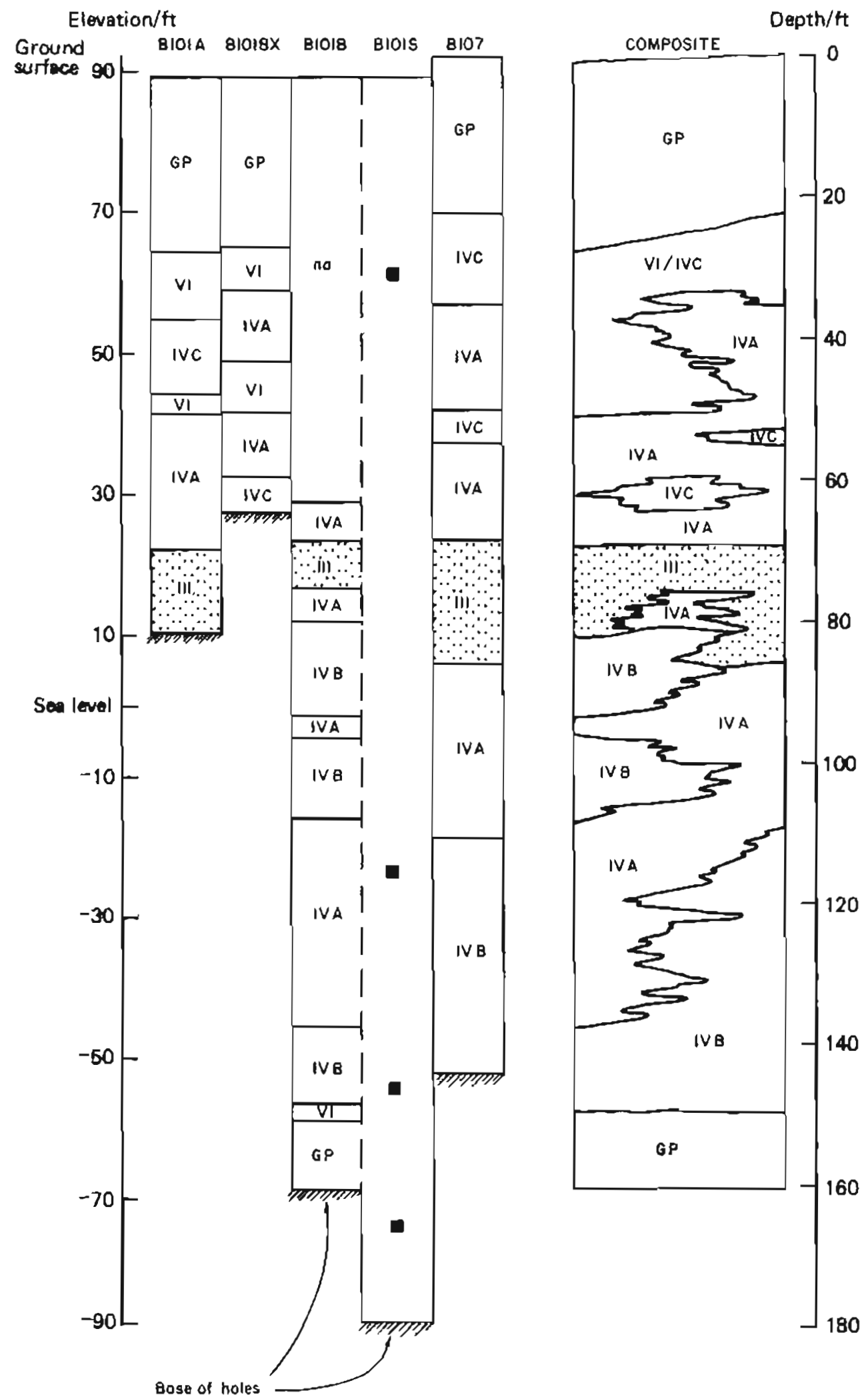

Figure 13. Borehole logs for sites at and near slope inclinometer site B101, B series 1, L Street slide zone (fig, 7). Composite cross section at right interpreted from borehole logs. (See lable 3 for symbology.) 


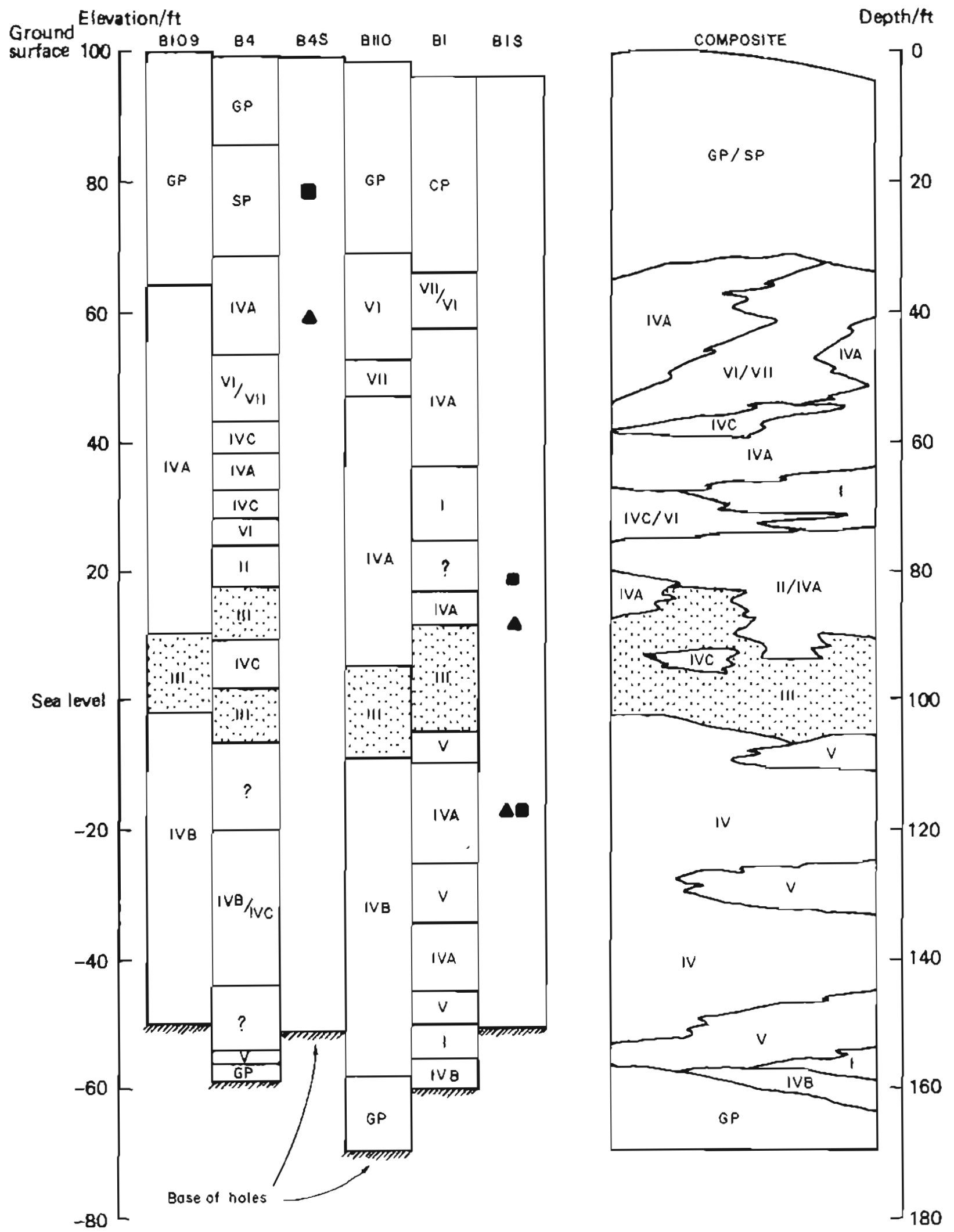

Figure 14. Borehole logs for sites at or near slope inclinometer sites 81 and B4, B series 2, L Street slide zone (fig. 7). Composite cross section at right interjereted from borehole logs. (See table 3 for symbology) 


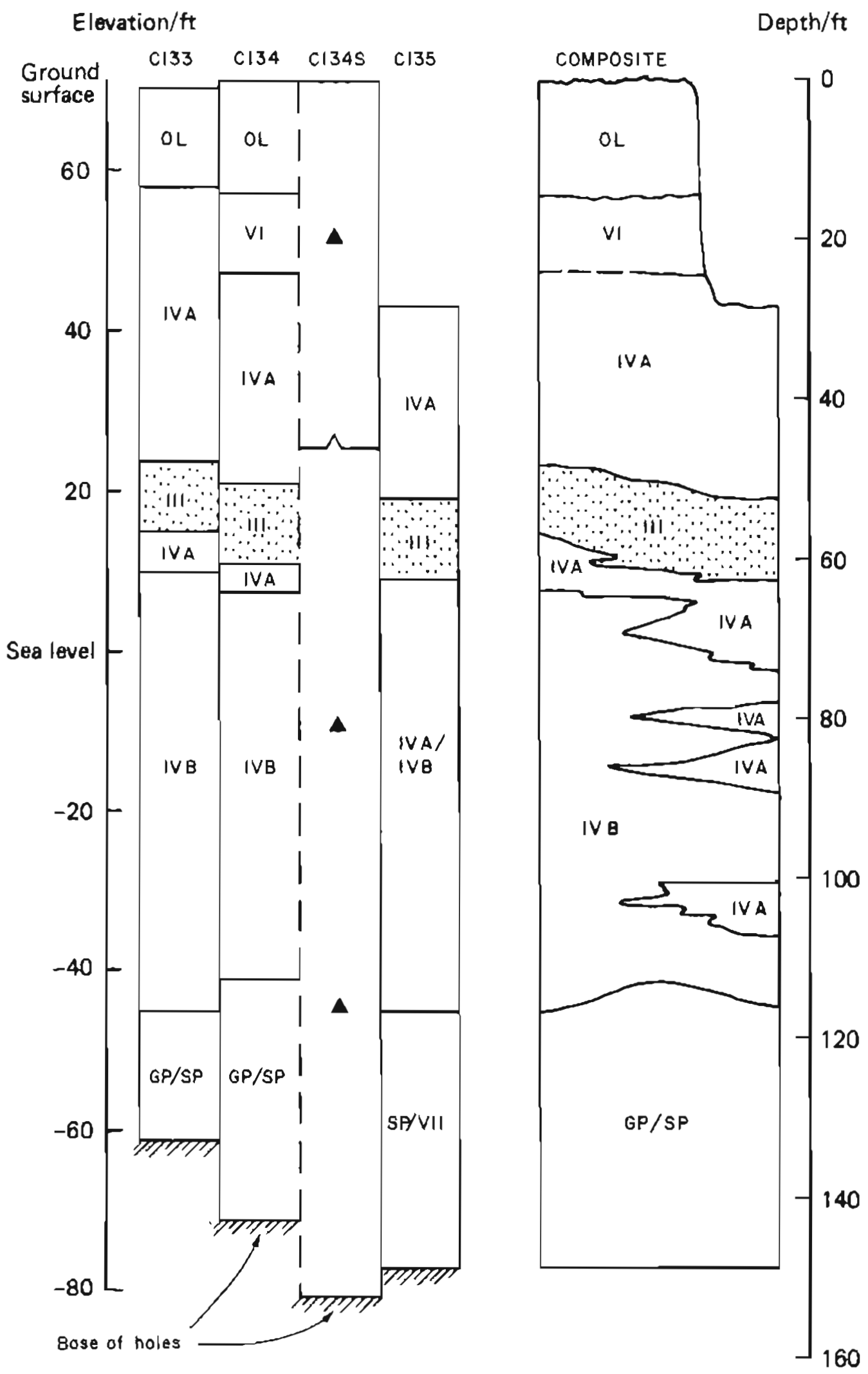

Figure 15. Borehole logs for sites at or near slope inclinometer site C134, C series 1, Turnagain Heights slide zone (fig. 8). Composite cross section at right interpreted from borehole logs. (See table 3 for symbology.) 
Elevation/ft

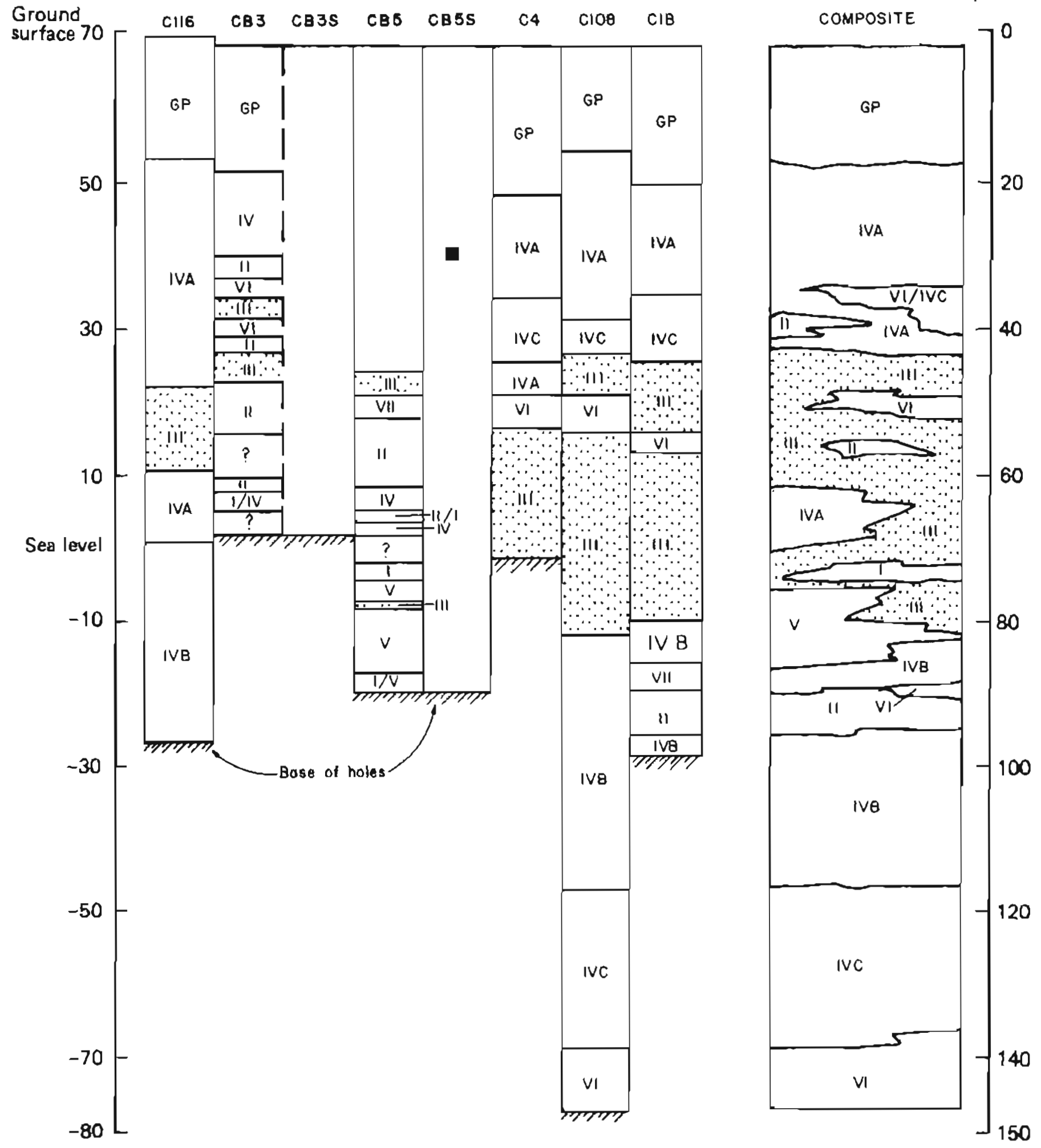

Figure 16. Borehole logs for sites at or near slope inclinometer site CB3 and CB5, C series 2, Turnagain Heights slide zone (fig. 8). Composite cross section at right intelpreted from borehole logs. (See table 3 for symbology.) 


\section{FOURTH AVENUE SLIDE}

Figure 10 shows that the inflections of $A$ series 1 are essentially limited to the slide zone; the composite cross section suggests that the base of the failure zone correlates with a massive F.III zone. Noncohesive facies appear to have been dislocated downsiope, but the stratigraphy remained intact at the casing site. Although the inflections are tied to a variety of facies conditions, an inflection in F.III is recorded in three of the four casings 15 to $20 \mathrm{fl}$ above mean sea level, the probable failure zone Por the Fourth Avenue slide. Other inflec tions in A2S and A3S occur near the F.IIl zones. A series 2 also shows evidence of irregularities, both on installation and afterwards, at the probable depth of shear (composite seclion, fig. 10). The only inflection observed in A series 3, where there is an appareni absence of F.III and lack of shear zones, occurs at the very top of the formation (fig. 12).

\section{STREET SLIDE}

Composite $B$ series 1 and 2 drawn for the L Street slide are (figs. 13 and 14) indicale that F.III is present from about 15 to $20 \mathrm{fl}$ above sea level, but is far more restricted than that in the Fourth Avenue slide area. The sand facies are also restricled primarily to the uppermost part of the formation. Casings in the $\mathrm{L}$ Street slide area reveal little indication of significant deformation, and only in inclinometer BIS is there a correlation between an inflection and F.III. Installation inflections occur In the uppermost part of the formation, probably because of the transition from overlying sandy gravels into fine sand.

\section{TUR NAGAIN HEJGHTS SLIDE}

Composite $C$ series 1 (fig. 15) js drawn in the area of Turnagain Heights that is now known as Earthquakc Park. Although the lateral correlation of F.III is excellent, no inflections are apparent. The obstruction at $+25 \mathrm{ft}$ was man-introduced debris; the other inflections mark the upper and lower transitions of the formation. Near Lynn Ary Park, composite $C$ series 2 shows that $F . I I I$ is abundant from -15 to +25 f from mean sea level, although it is intercalated extensively with other facies. Casings CB $3 S$ and CB5S backfilled with clayey silt to an elevation of about $+25 \mathrm{fl}$ within a few monchs after installation, which suggests a high mobility within the zone dominated by F.IIl. Facies F.VI is directly adjacent to F.III and may act as a confined aquifer that provides fresh waley flow to the sensitive zone.

\section{CONCLUSIONS}

The study served two primary functions. First, it established a baseline for the configuration of the slope inclinometer casings relative to the engineering geologic facies of the Bootlegger Cove Formation. Second, the sludy compared data compiled over a 15-yr period for possible strain in the casings installed in the sites of the L Street, Turnagain Heights, and Fourth Avenue land. slides. The three slide zones have remained remarkably stable since the 1964 earthquake.

The L Street slide area, which has been extensively developed since the $\mathbf{1 9 6 4}$ event, shows no evidence of even minor displacement behind the present bluff line.

Slope-inclinometer installations that have survived since 1965 in the Tumagain Heights slide zone are far more sketchy; there is strong evidence for potential mobility at elevations from -5 to $+30 \mathrm{ft}$ from mean sea level, although the slide site seems to remain unaltered.

The Fourth Avenue slide zone also shows stability behind the 1964 scarp, although the so-called buttress area north of the Post Office Mall may be of some concern. Comparing 1976-80 data with the 1964-65 records for casings $\mathrm{A} 2 \mathrm{~A}$ and $\mathrm{A} 3 \mathrm{~A}$ indicates that several zones of strain occurred. Some of the strain may be attributed to 1965.76 construction; however, the considerable depths at which deflections have occurred are far beyond those that would be affected by nearsurface disturbance. Further, the zones of deflections have a very strong correlation with facies F.III and F.IV. The 1976 and 1980 records show liltle evidence of further strain, which implies that the strain has, al least in recent years, ceased. Concern for this area remains significant. The casings here, particularly Nos. A5 and A 1005, should continue to be monitored, particularly after future strong-mution seismic events.

Unfortunately, most of the casings installed after the 1964 earthquake were lost to construction. The remaining sites should be preserved and monitored periodically.

\section{ACKNOWLEDGMENTS}

I thank R.D. Reger, S.E. Rawlinson, and J.E. Decker for their careful review of the manuscript, and M.E. Pritchard and G.D. Olsen for their graphics, I thank the U.S. Army Corps of Engineers for providing access to their extensive (i)es of historic data. The State of Alaska Department of Tyansportation and Public Facilities provided me with Sinco Digitilt Inclinometer equipment. The project was funded under a cooperative agreement between the Alaska DGGS and the U.S. Geological Survey Earthquake Hazards Reduction Program.

\section{REFERENCES CITED}

Casagrande, Arthur, 19\%6, Liquefaction and cyclic deformation of sand - a critical review: Harvard University Soil Mechanics Series, no. 88, $51 \mathrm{p}$. Hansen, W.R, 1965, Effects of the earthquake of March 27, 1964, at Anchorage, Alaska: U.S. Geological- 
Survey Professional Paper 542A, D. A1-A68.

Karlstrom, T.N.V., 1964, Quaternary geology of the Kenai Lowland and glacial history of the Cook Inlet region, Alaska: U.S. Geological Survey Protessional Paper 443,69 p.

Kerr, P.F., Drew, I.M., 1965, Quick clay movements, Anchorage, Alasks: Speingfield, Virginia, National Technical Information Service Document AD630$111,133 \mathrm{p}$.

1968, Quick-clay slides in the U.S.A.: Engineering Geology - An International Journal, v. 2 , p. 215-238.

Long, Erwin, and George, Warren, 1966, Buttress design for earthquake-induced slides: Conference on stability and performance of slopes and embankments, Berkeley, Soil Mechanics and Foundations Division, American Society of Civil Engineers, p. 657-671.

Miller, R.D., and Dobrovolny, Ernest, 1959, Surficial geology of Anchorage and vicinity, Alaska: U.S. Geological Survey Bulletin 1093, 128 .

Mitchell, J.K., 1960, Fundamental aspects of thixotropy in soils: Soil Mechanics and Foundations Division, American Society of Civil Engineers, v. 86, p. 19-52.

Schmoll, H.K., and Dobrovolny, Ernest, 1972, Generalized geologic map of Anchorage and vicinity, Alaska: U.S. Geological Survey Miscellaneous Geological Investigat ions Map [-787 A.

Schmoll, H.R., Szabo, B.J., Rubin, Meyer, and Dobrovolny, Ernest, 1972, Radiometric dating of marine shells from Bootlegger Cove Clay, Anchorage area, Alaska: Geological Society of America Bulletin, v. 83, p. $1107-1114$.

Seed, H.B., 1968, Landslides during earthquakes due to soil liquelaction: Soil Mechanics and Foundations Division, American Society of Civil Engineers, v. 94, p. 1053-1122.

-1976, Evaluation of soil liquefaction effects on level ground during earthquakes: Philadelphia. American Society of Civil Engineers Specialty Session on Liquelaction Problems in Geo. lechnical Engineering, p. 1-104.

Seed, H.B., and Wilson, S.D., 1967, The Turnagain Heights Landslide, Anchorage, Alaska: Soil Mechanics and Foundations Division, American Society of Civil Engineers, v. 93, p. 325-353.

Shannon and Wilson, Inc, 1964, Report on Anchorage area soil studies, Alaska, to the U.S. Army Engineer District, Anchorage, Alaska: Seatlle, Shannon and Wilson, inc., $109 \mathrm{p}$.

Stephens, C.D., Lahr, J.C., Fogleman, K.A., Itelton, S.M., Cancilla, R.S., Tam, R., and Baldonado, K.A., 2980 , Catalog of earthquakes in southern Alaska, Octo. ber-December, 1979: U.S. Geological Survey Open-file Report 80.2002, $53 \mathrm{p}$.

Updíke, R.G., 1983, Engineering geologic maps, Gov. ernment Hill area, Anchorage, Alaska: U.S. Geologica) Survey Miscellaneous Geological Investigations (I-series) maps [in press].

Updike, R.G., and Carpenter, B.A., 1983, Engineering geology of the Government Hill area, Anchorage, Alaska: U.S. Geological Survey Bulietin [in press]. 


\section{Appendix A \\ CASING PROFILES, 1979.80}

The following figures present the north-south and east-west casing profiles for those slope inclinometer casings that remained in existence in 1979 and 1980.

Each profile was obtaineo by the author, who used a Sinco Digitilt Inclinometer, Model C370 (instrument 50306), which was borrowed from the Alaska Department of Transportation and Public Facilities. The method of data acquisition and derivation of the following profiles is discussed in the text.

Each curve shows the deflection of the casing, in inches, relative to the base of the hole (BH), and is plotted with respect to depth below the existing grade. 


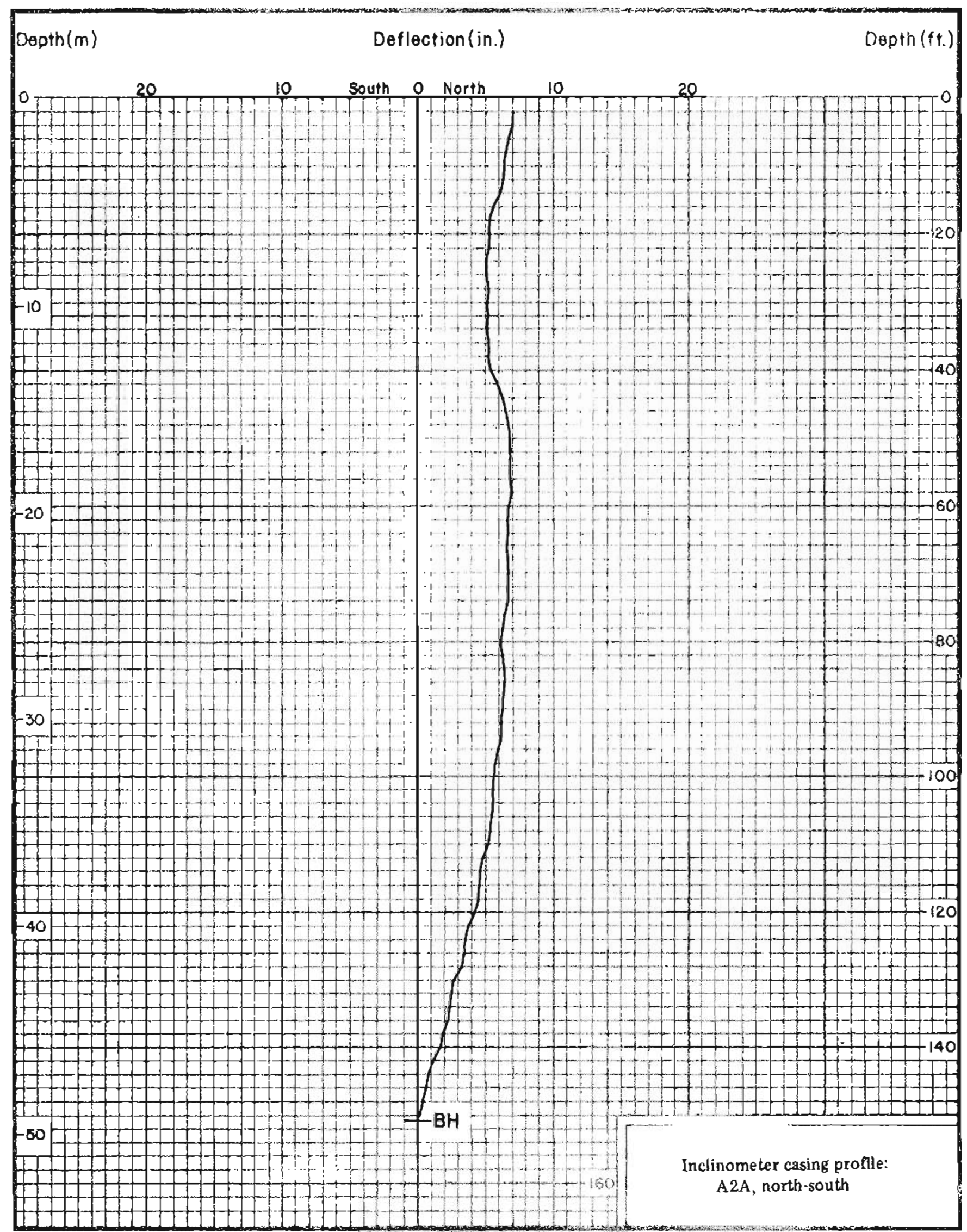




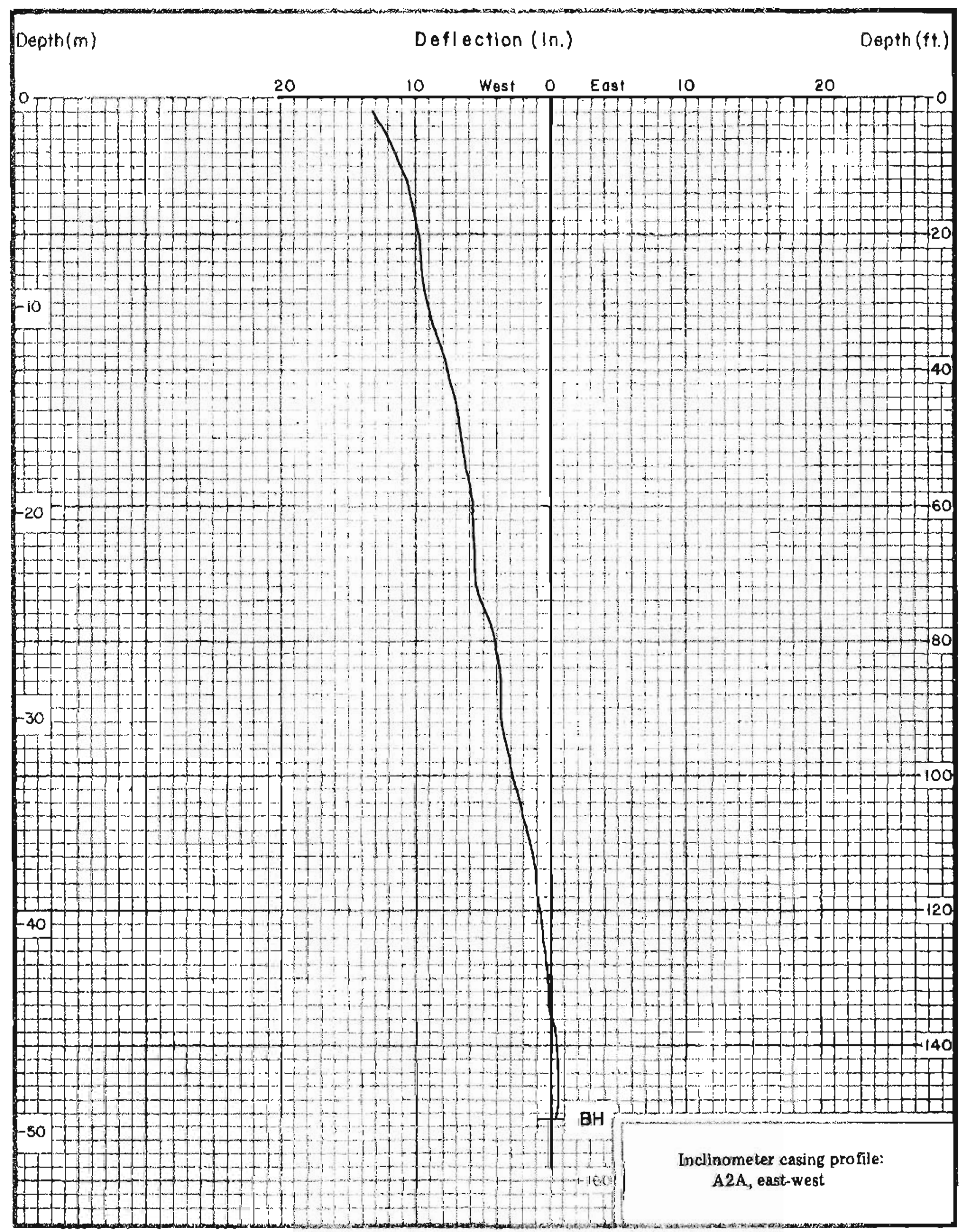




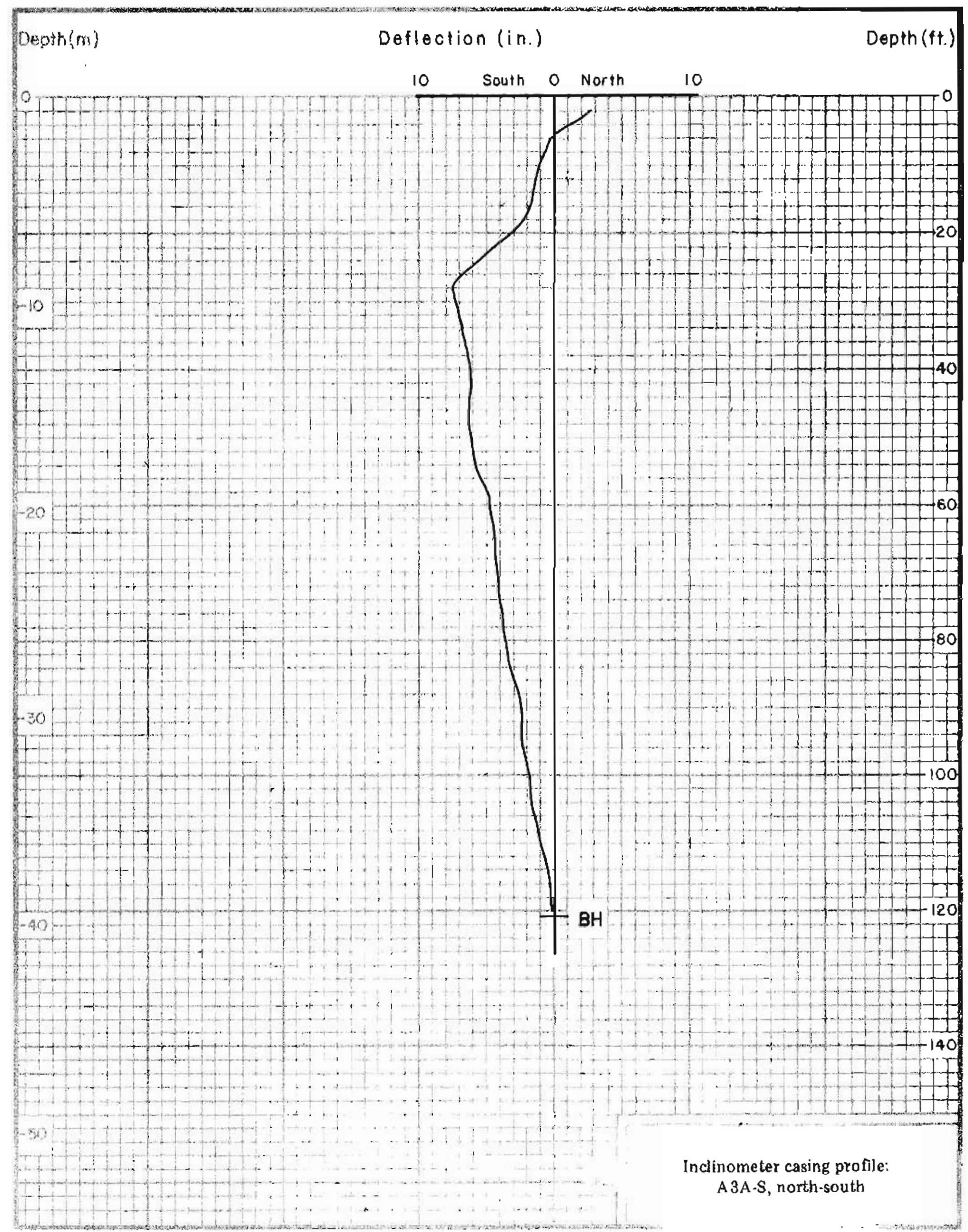




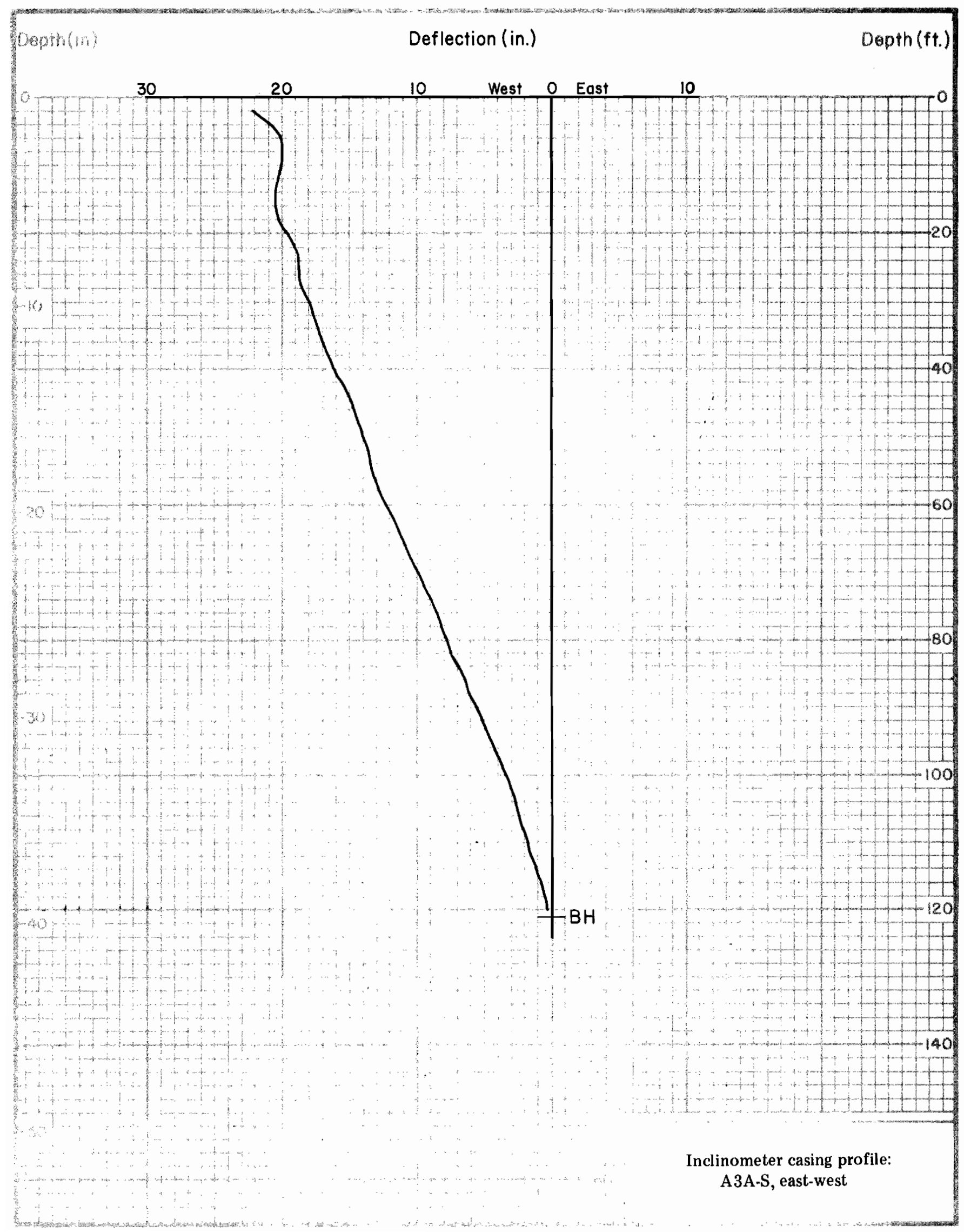




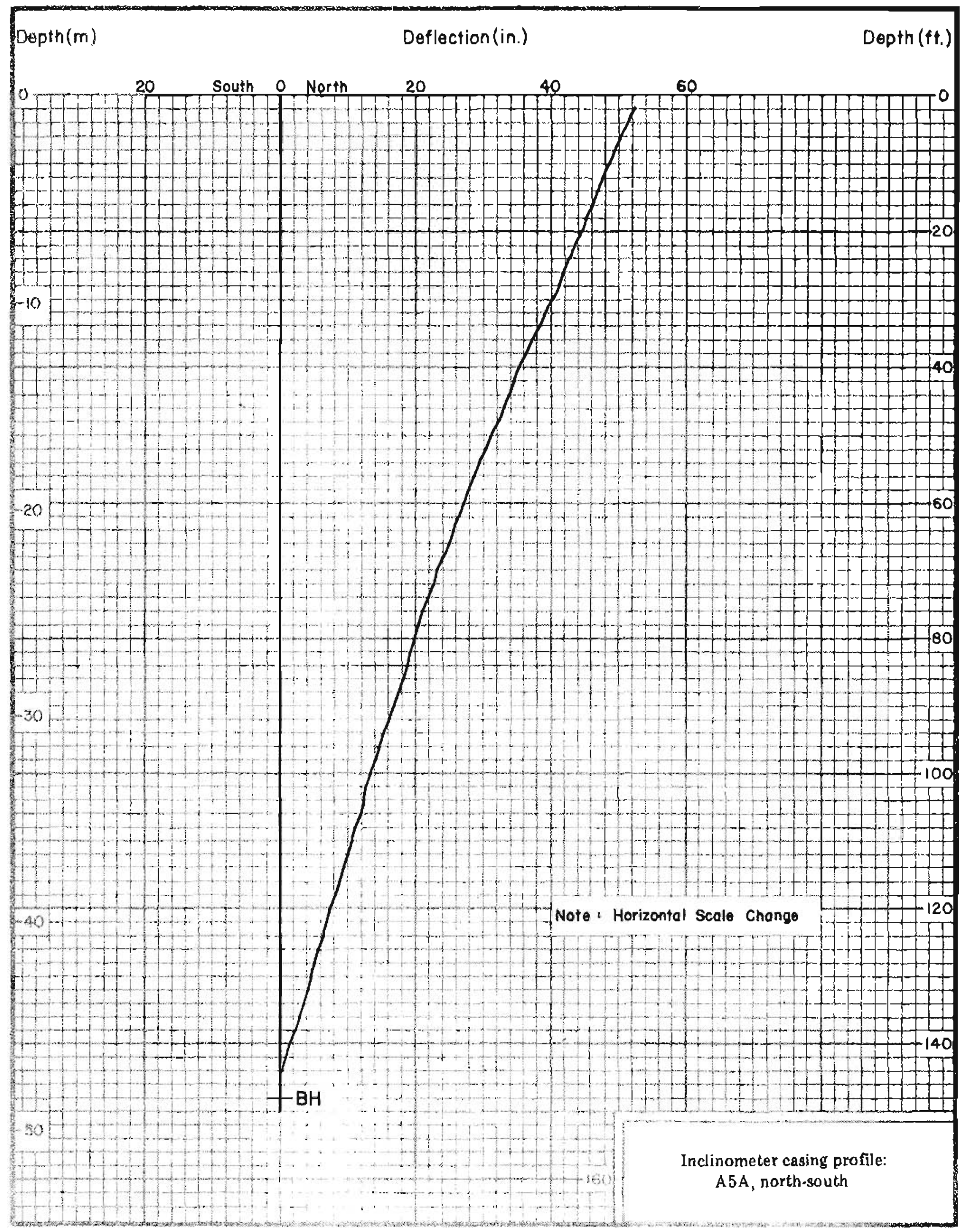




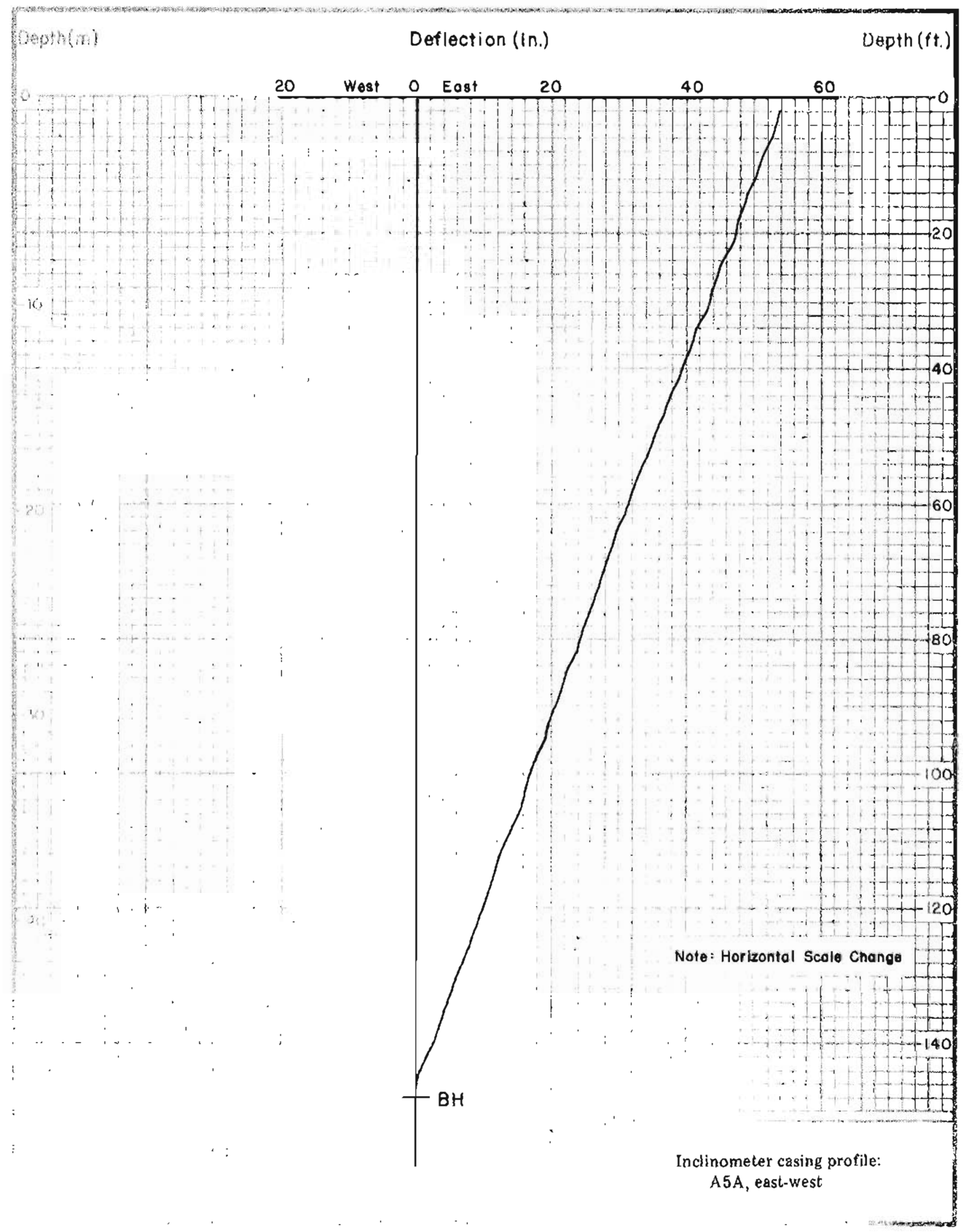




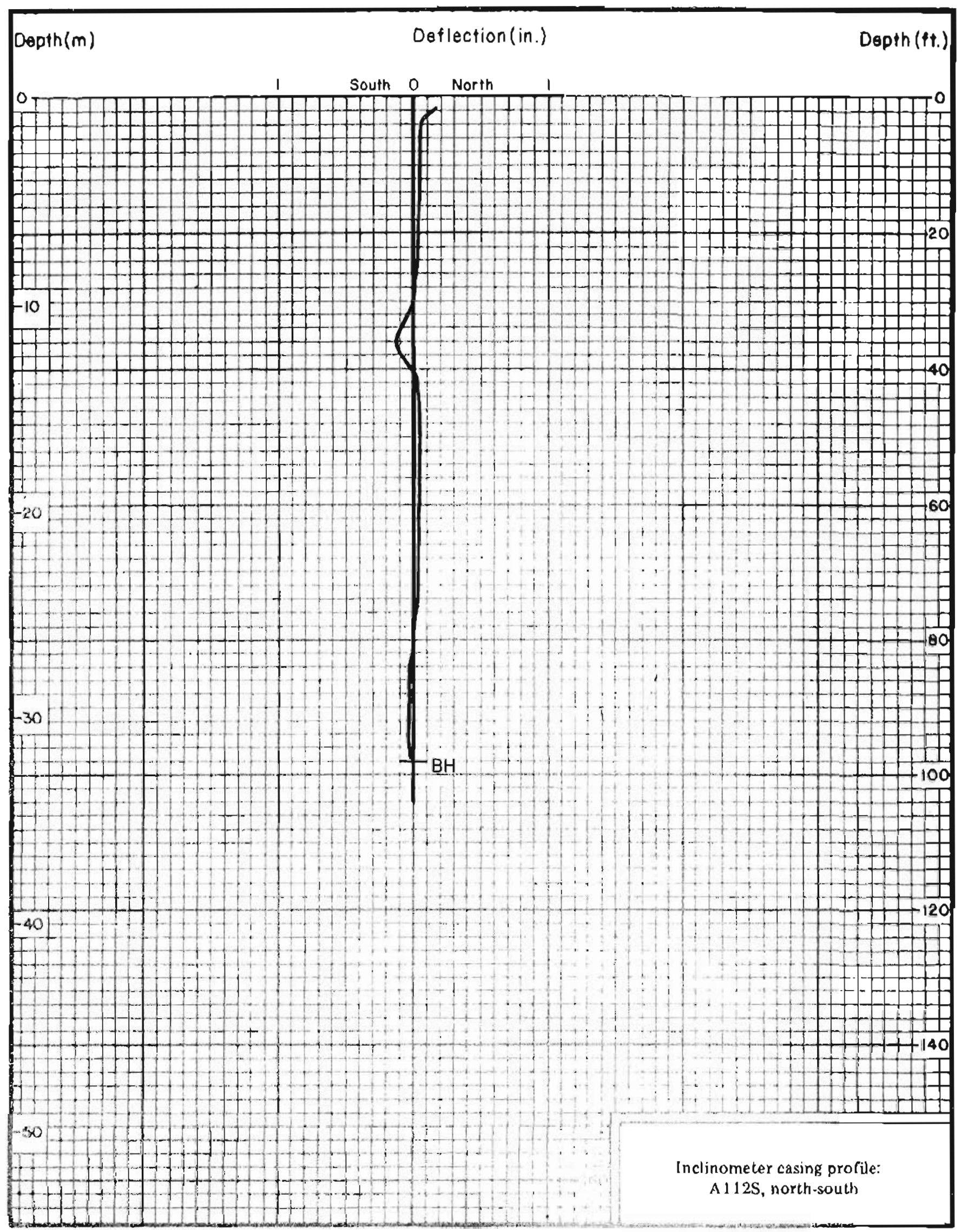




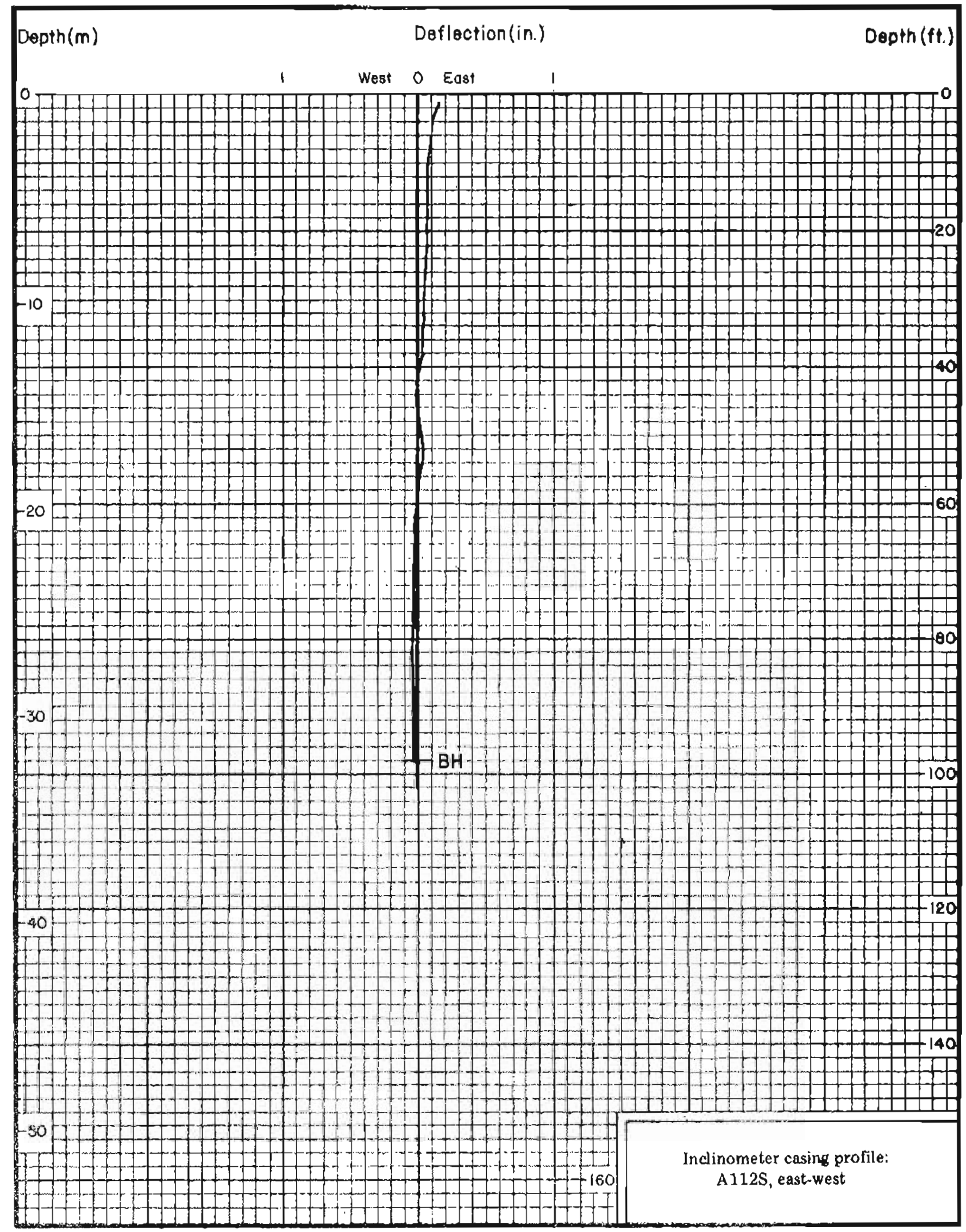




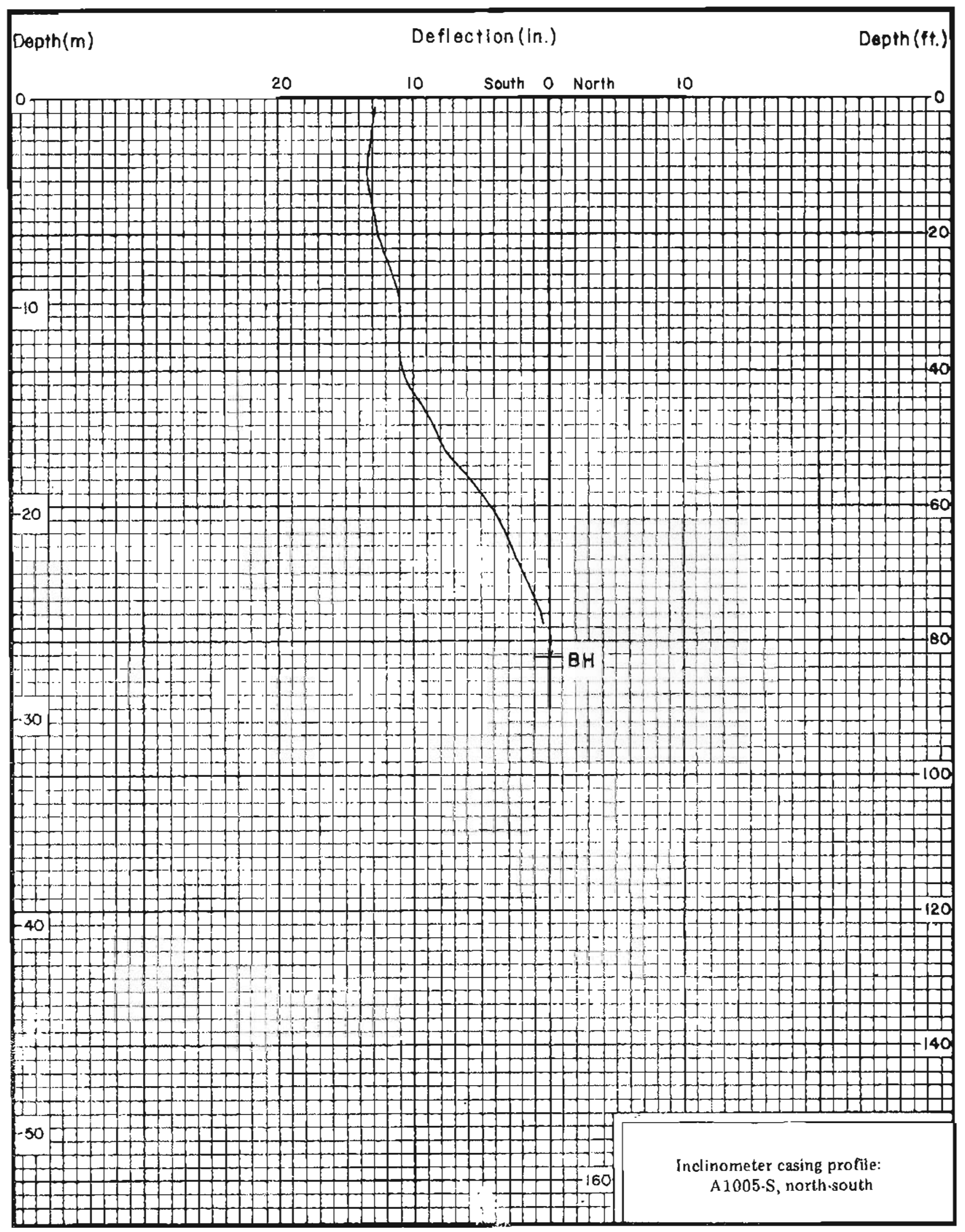




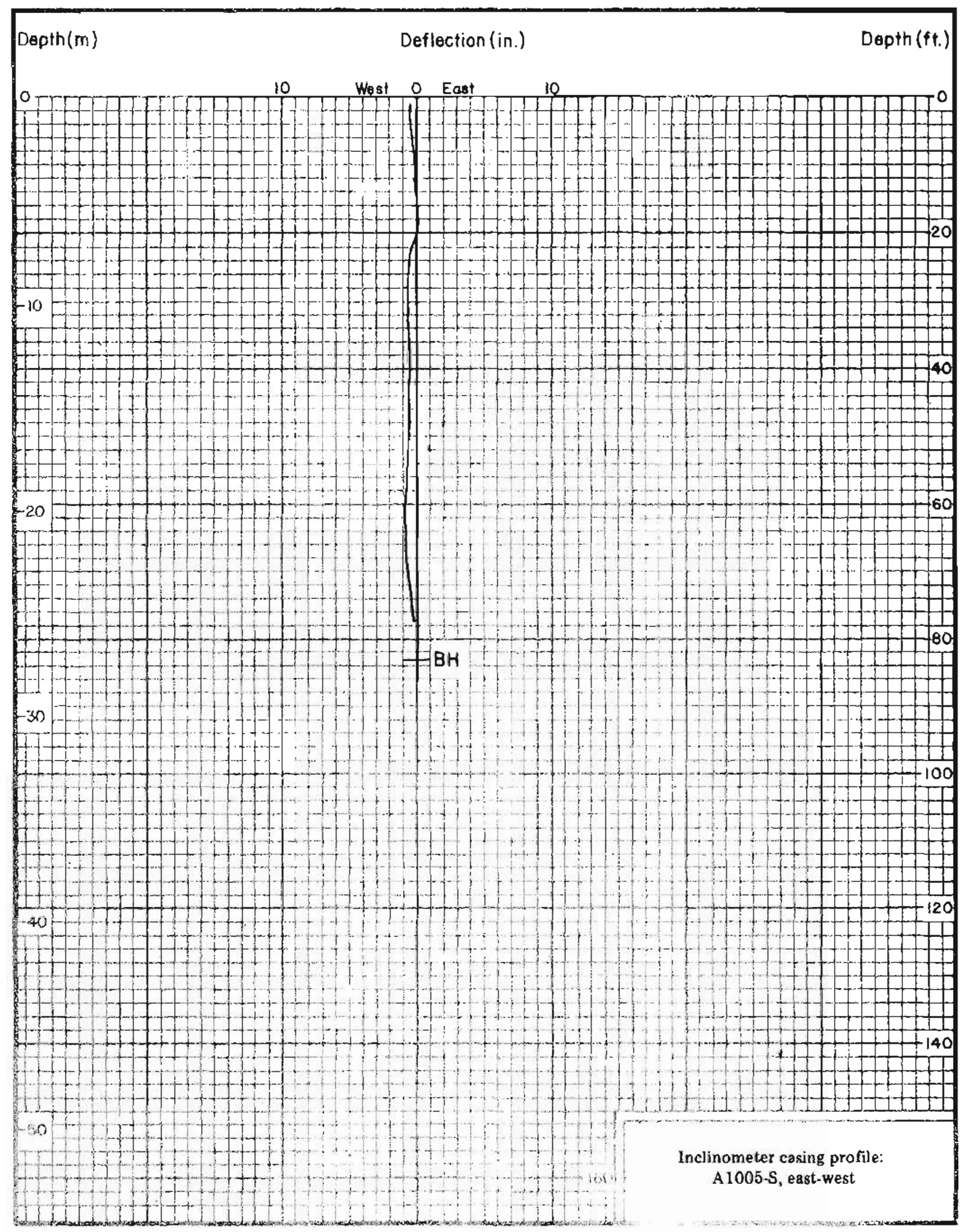




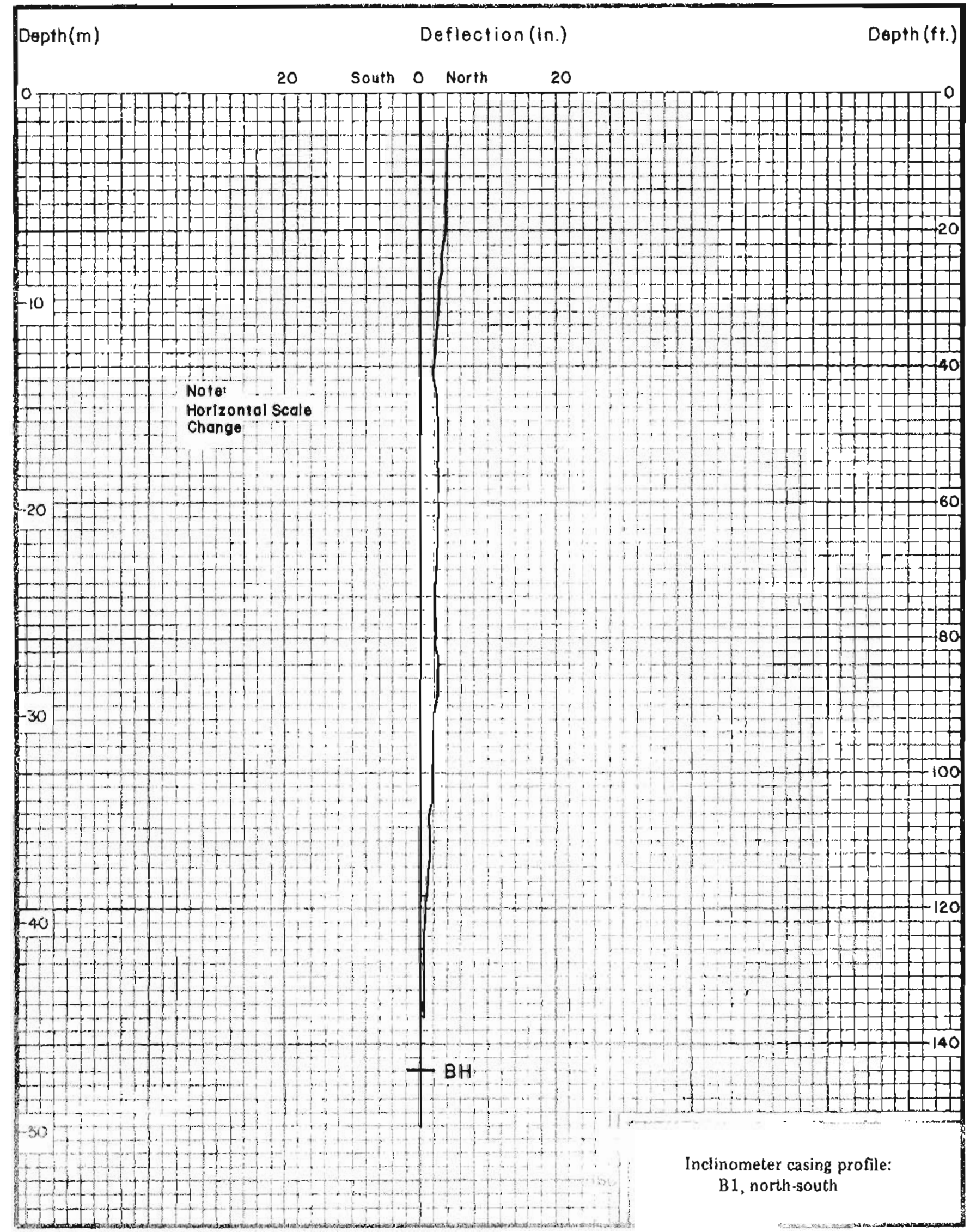




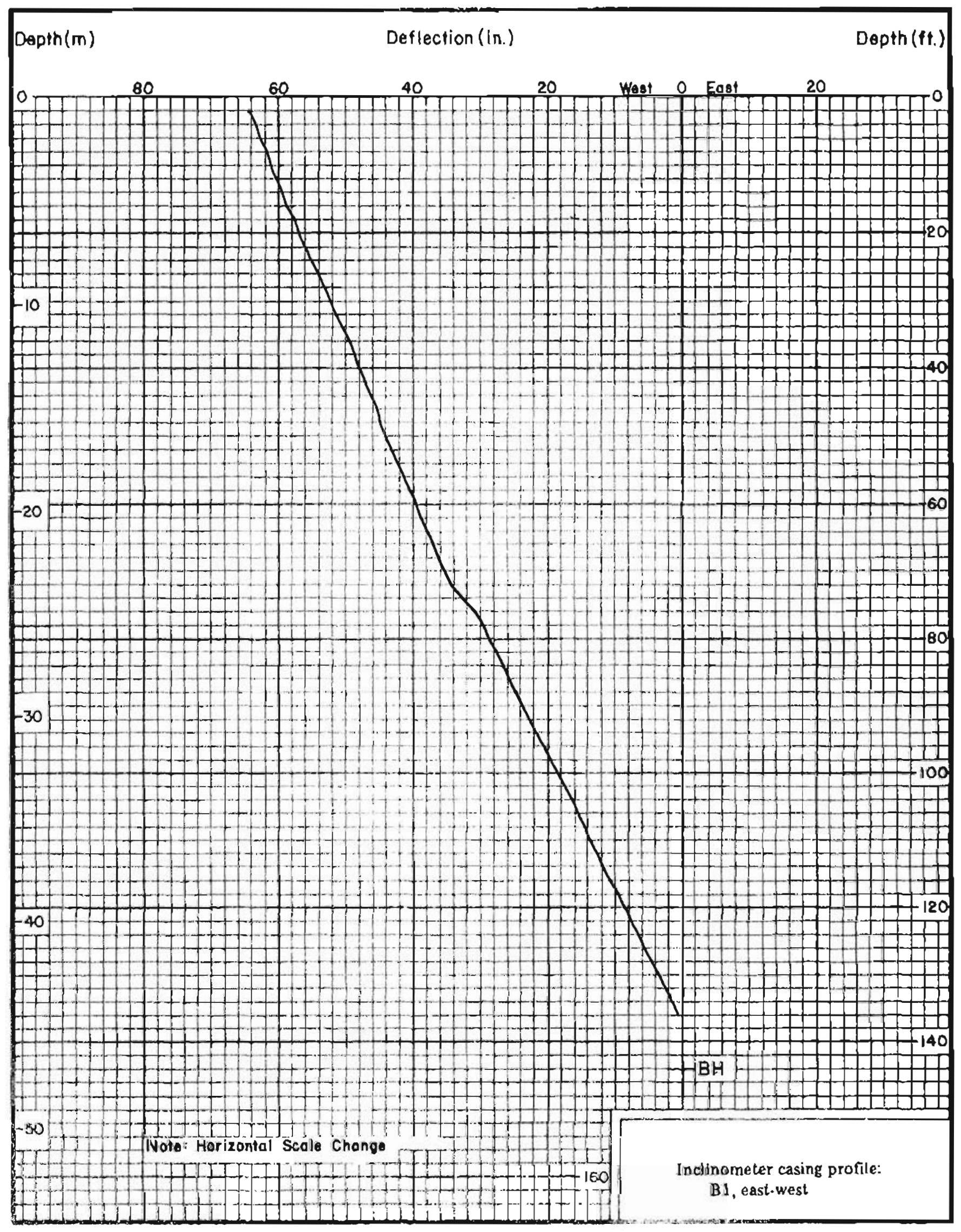




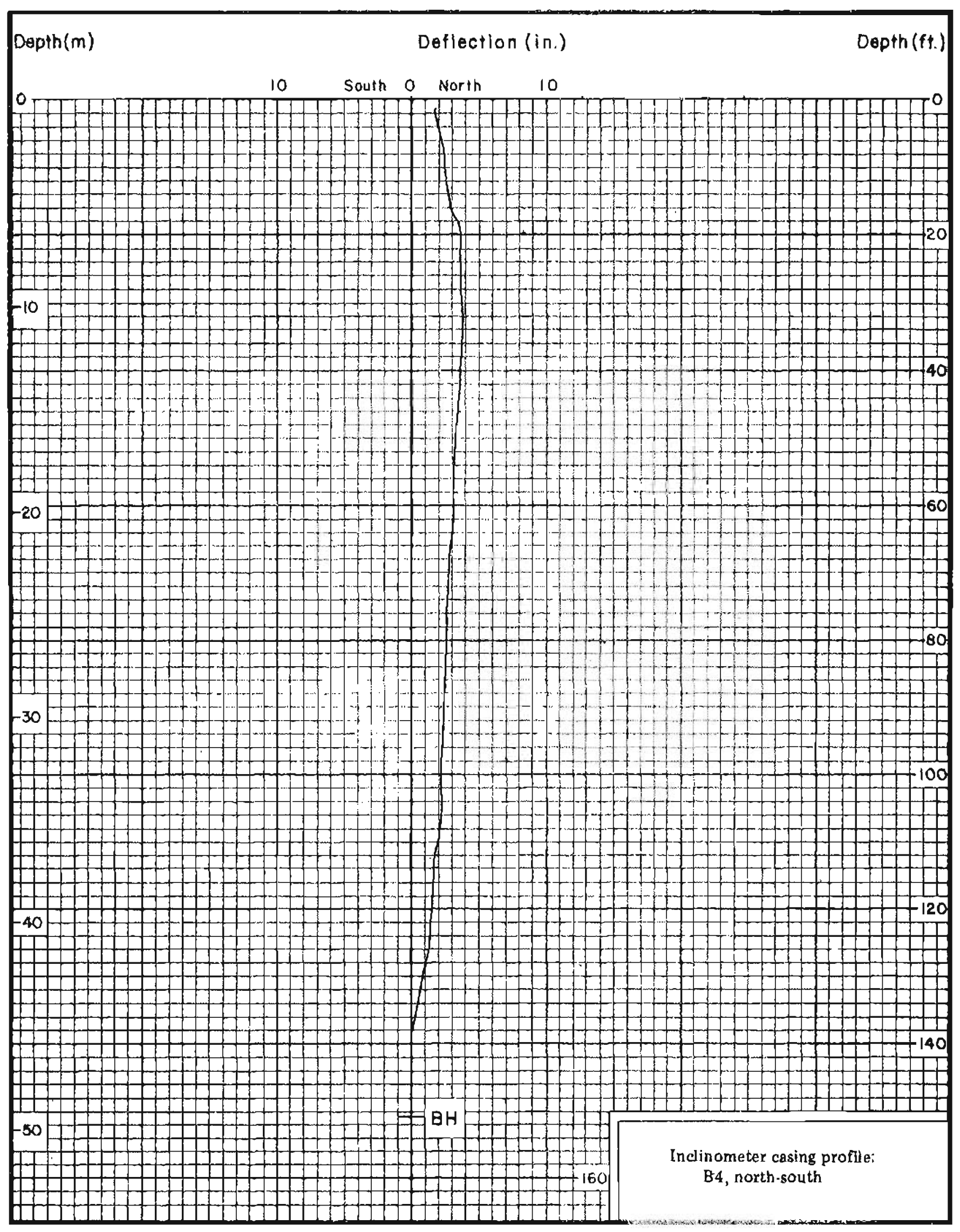




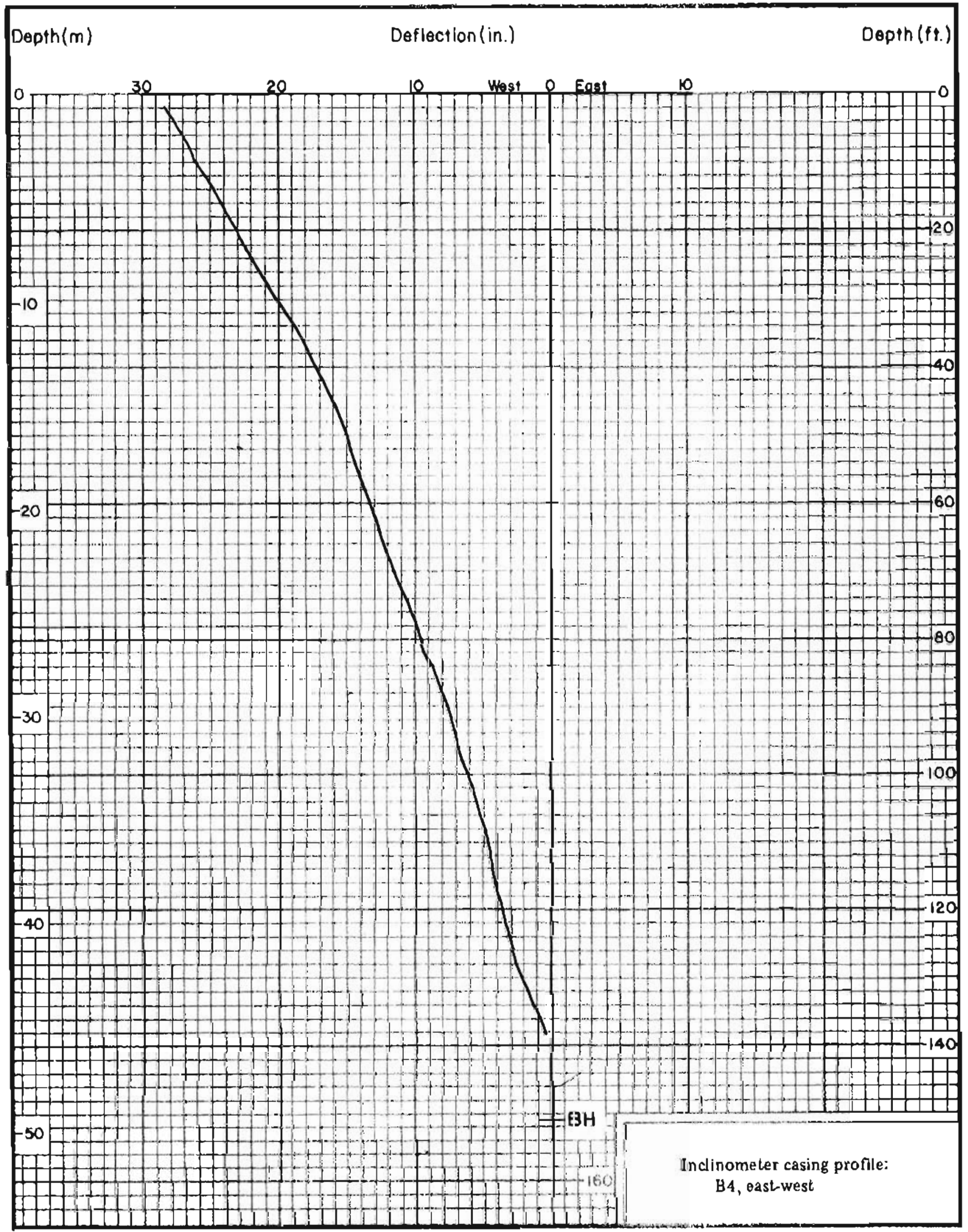




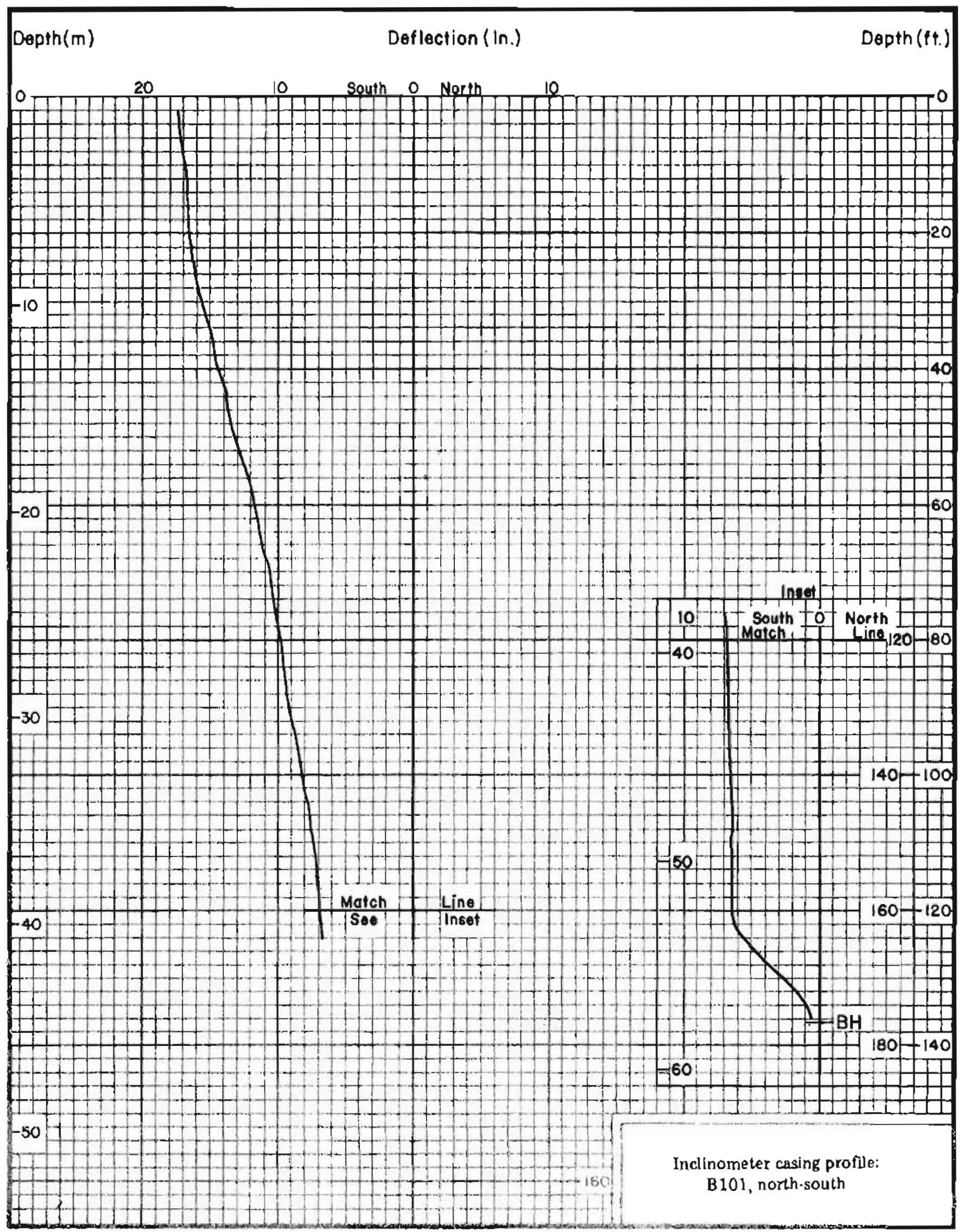




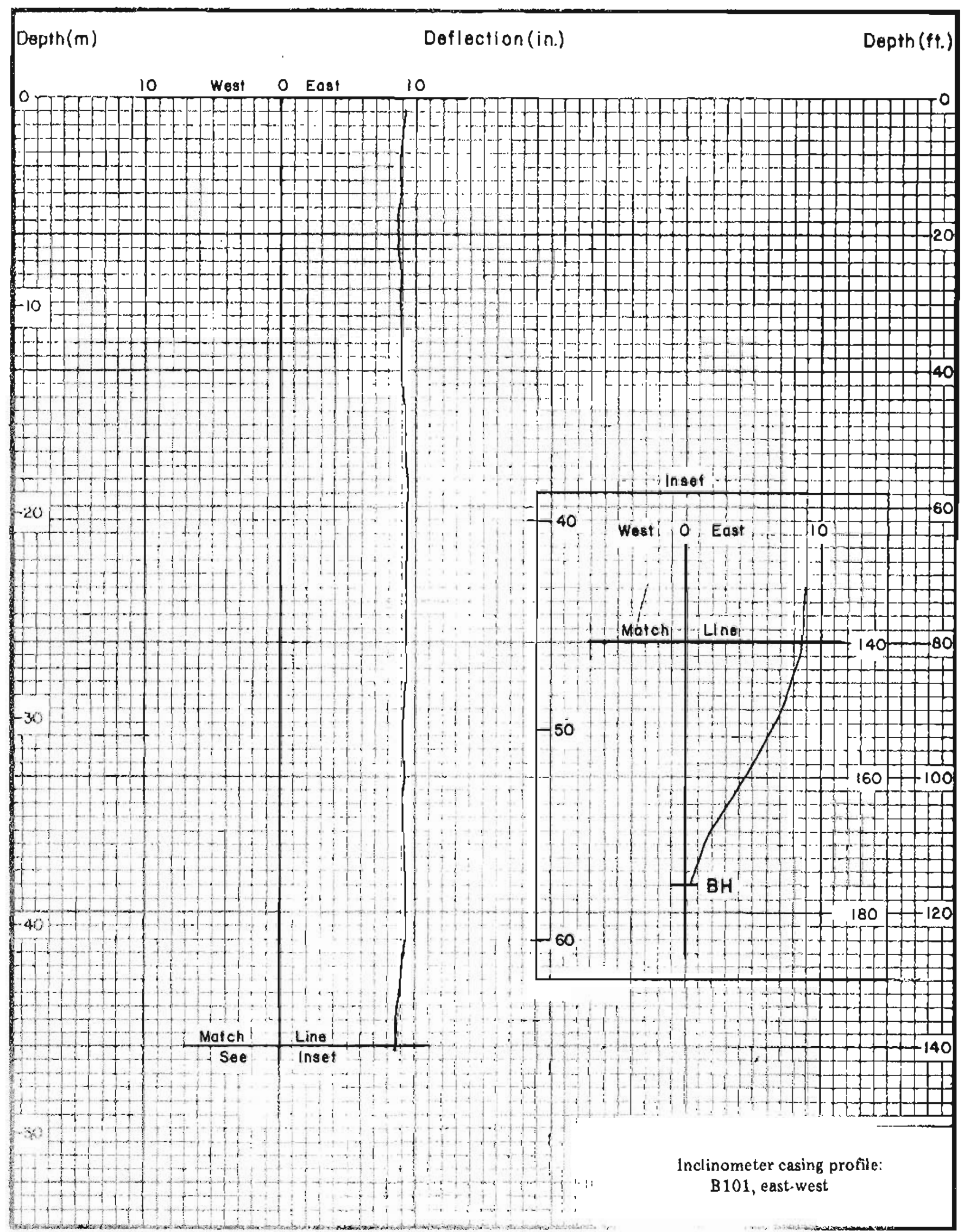




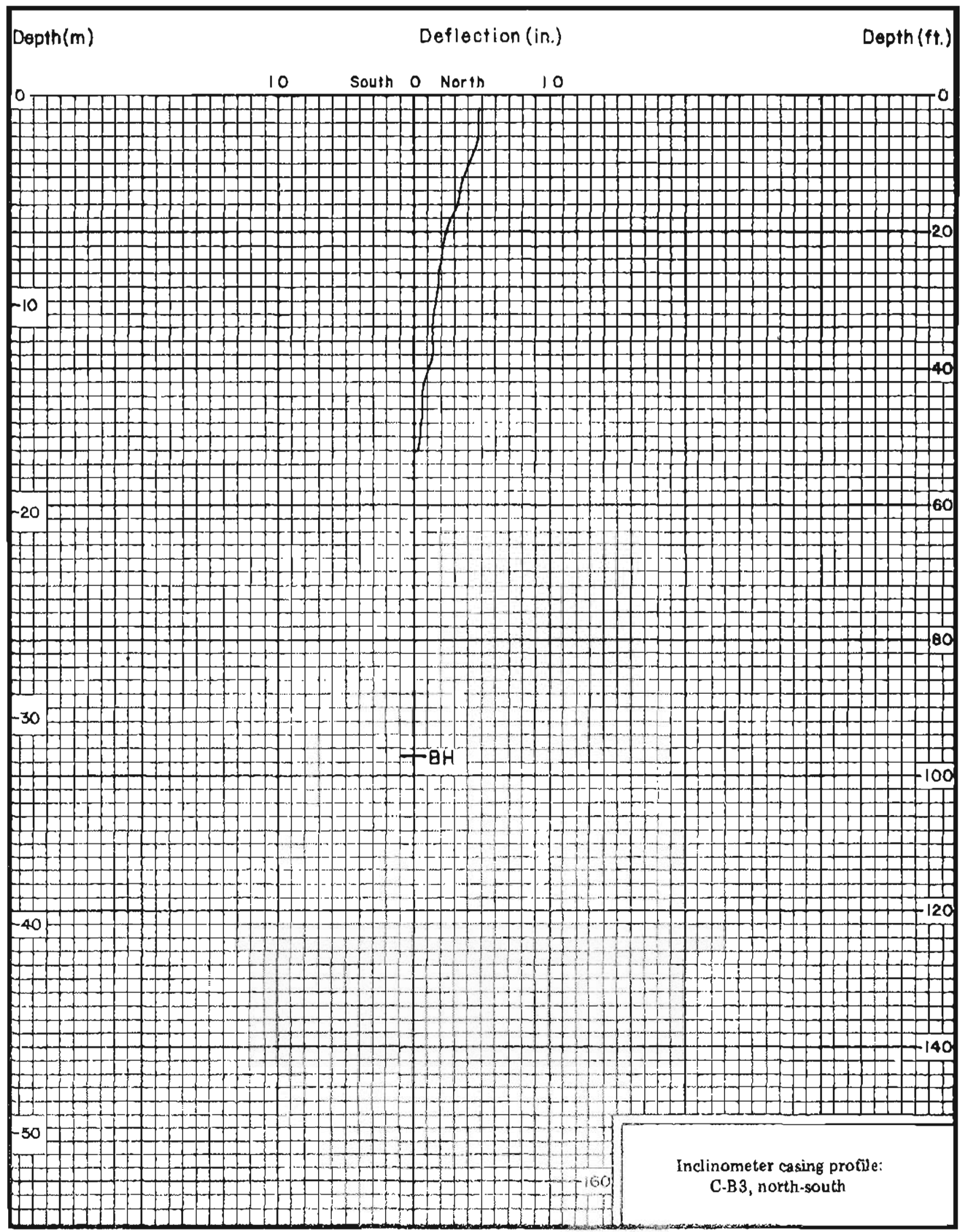




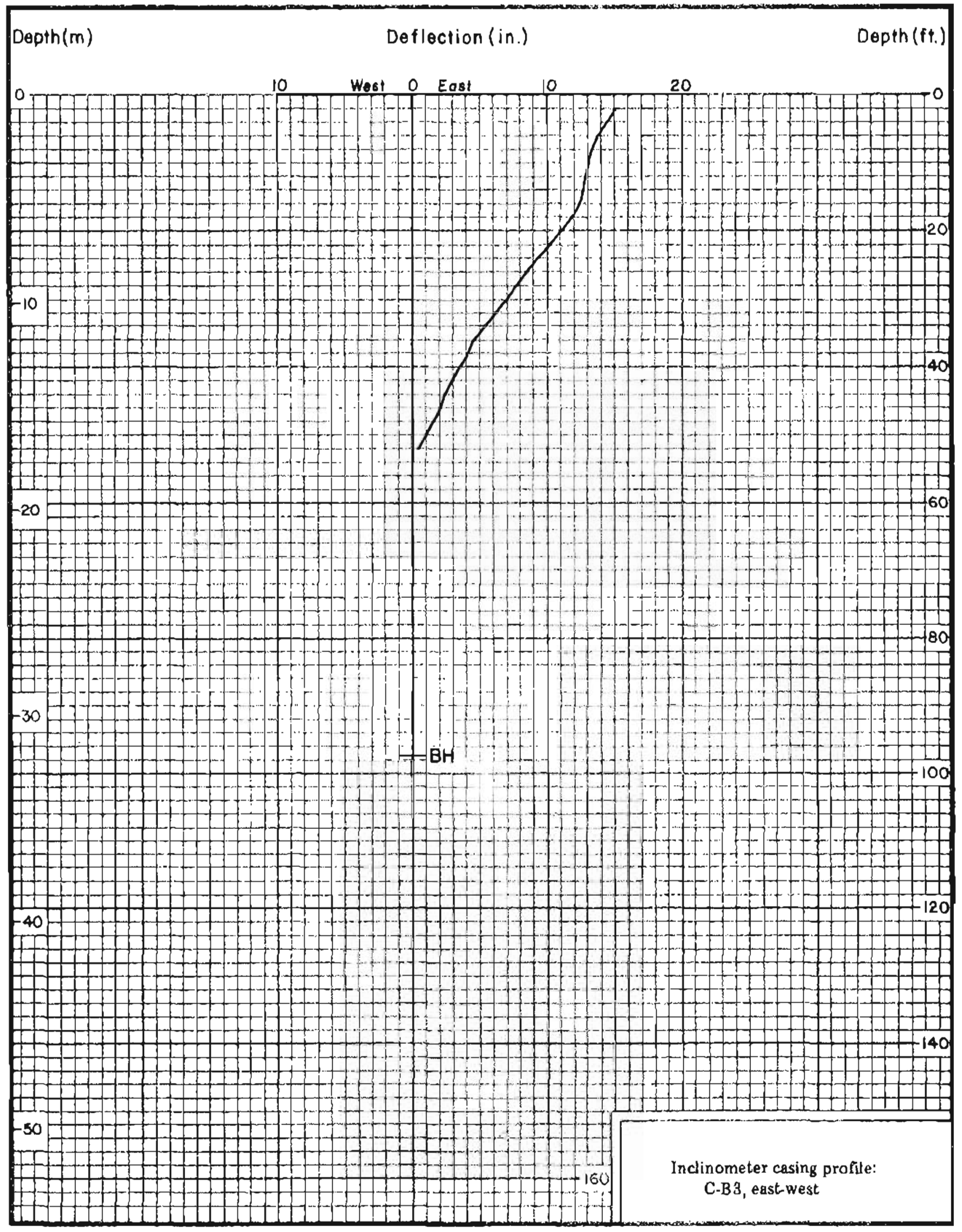




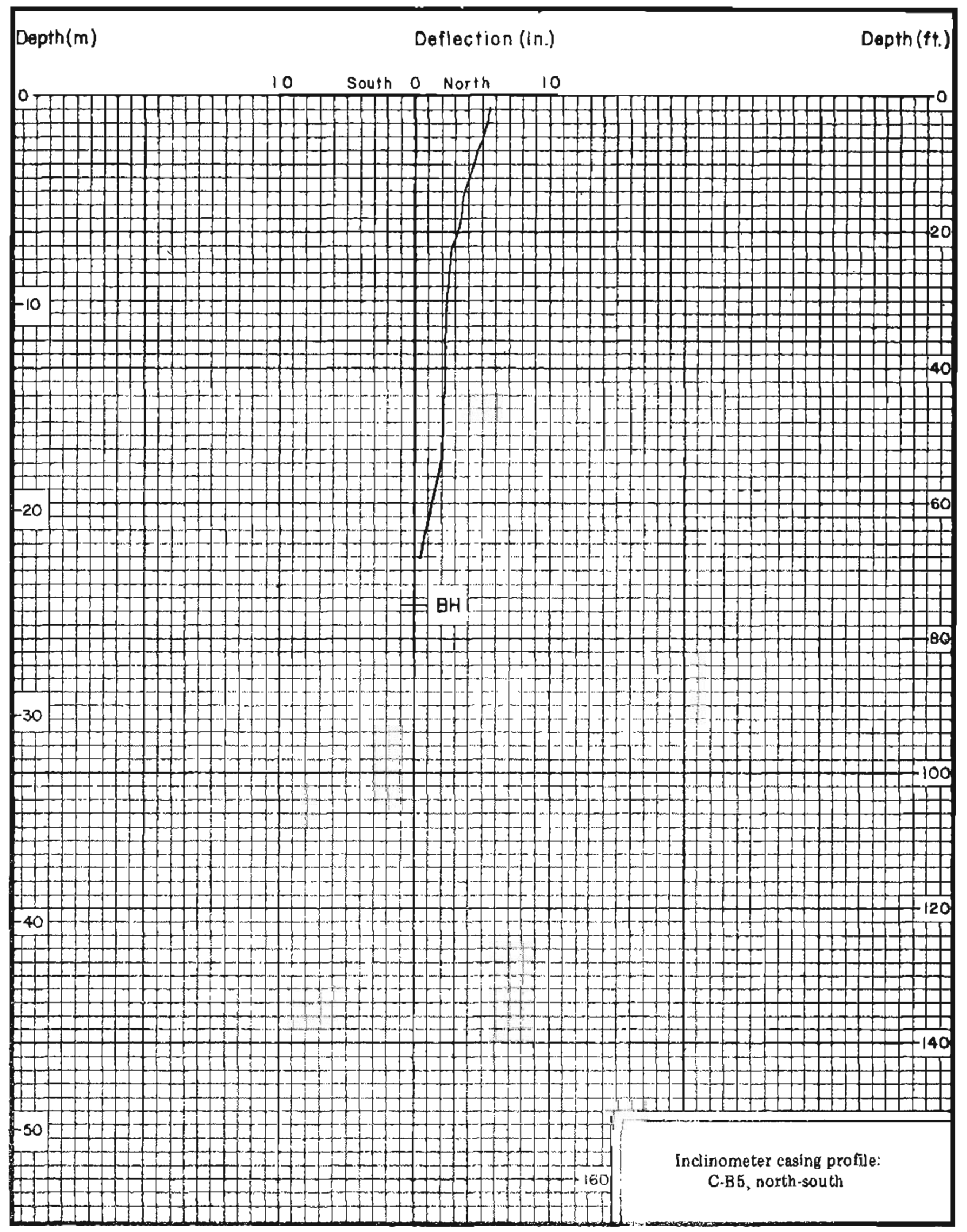




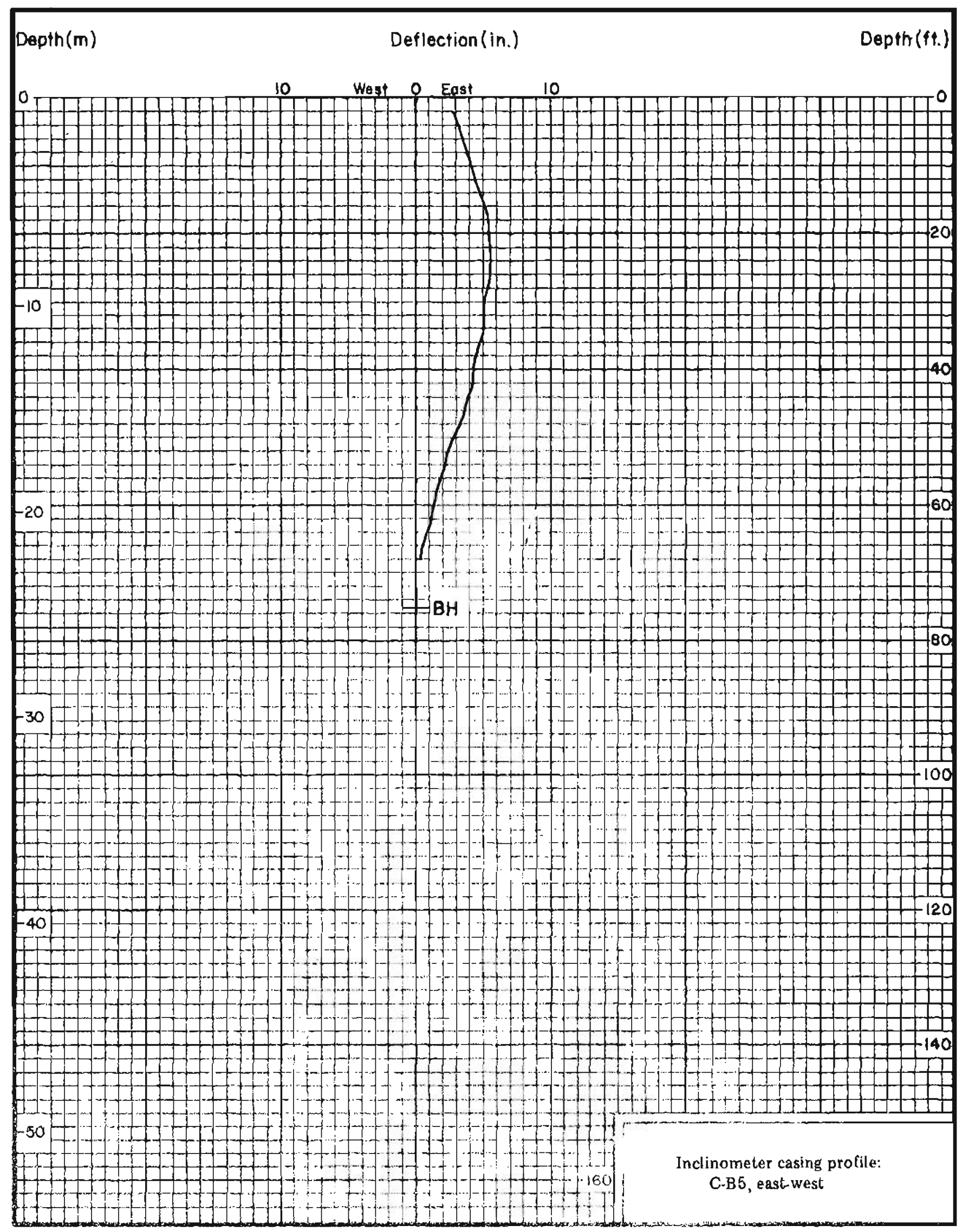




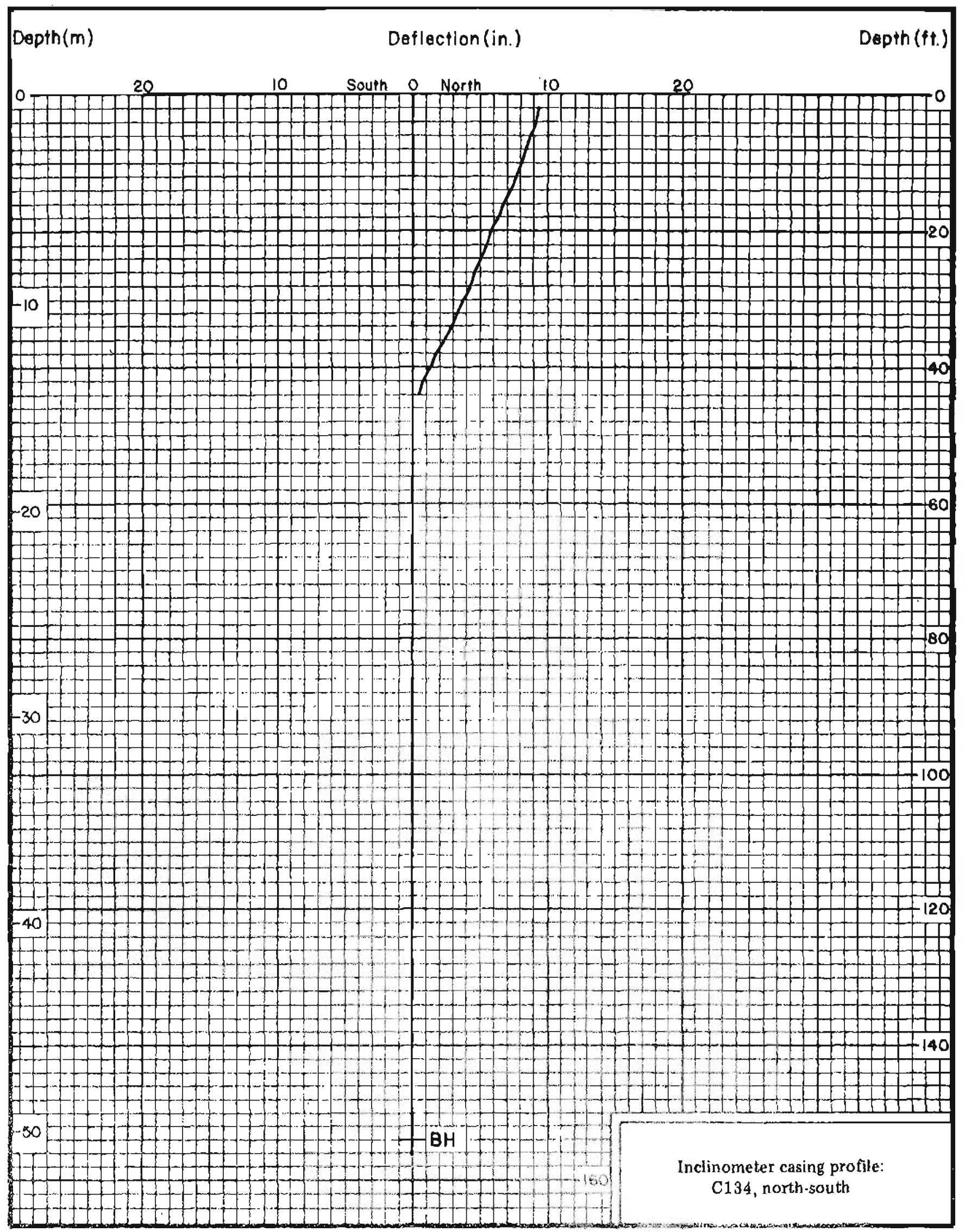




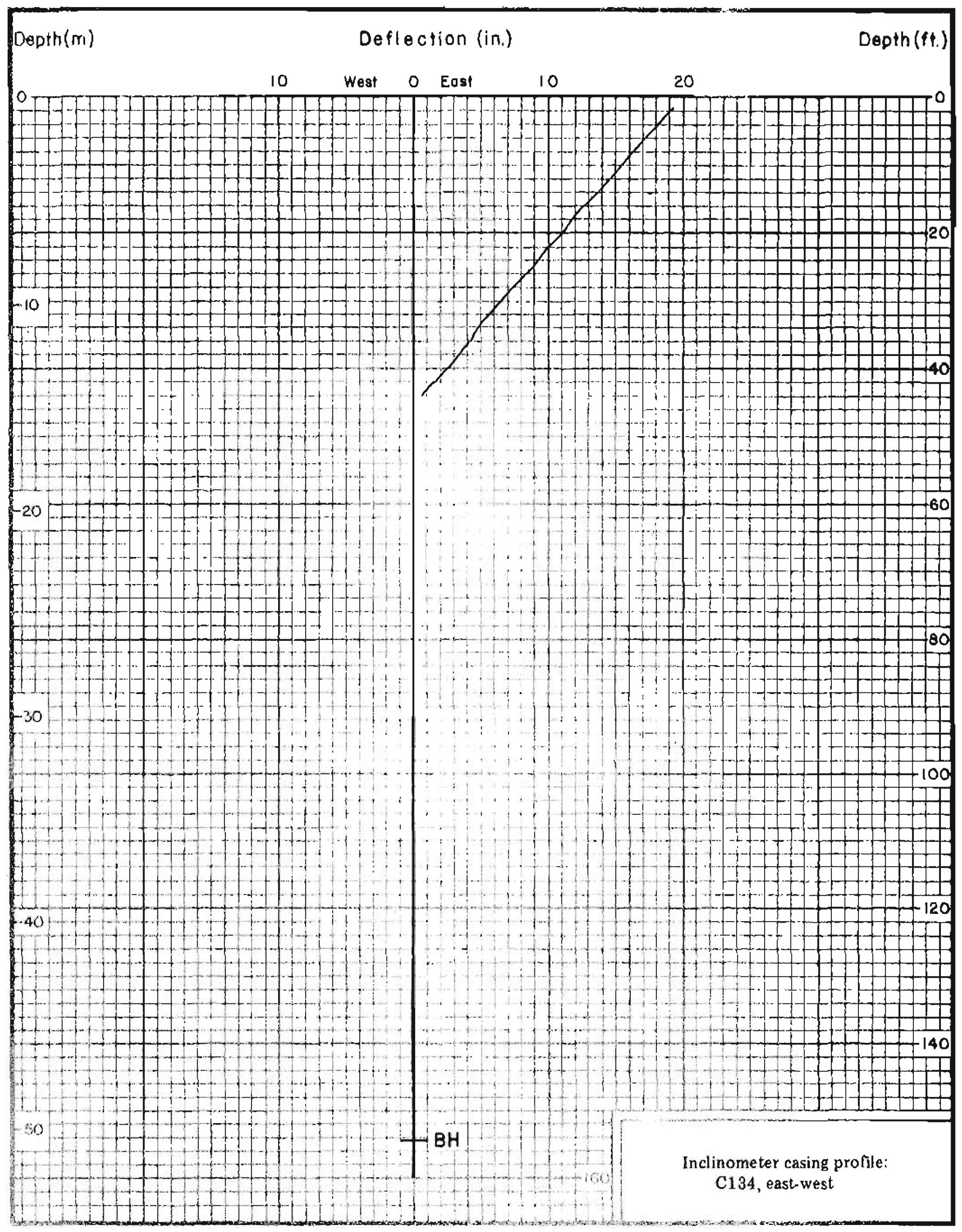




\section{Appendix B}

\section{SLOPE-INDICATOR CASINGS}

This appendix presents summary data for slope-indicator casings installed in Anchorage before the 1964 Prince William Sound Earthquake. Text figures 6-8 show casing locations; text table 1 reports their condition as of December 1980.

The columns denoted 'Inilial' are the algebraic differences of the two sets of readings used in the initial calibration of the casings. Those denoted 'DEFL' are calculated cumulative deflections, in inches, from the initial 1964 calibrations. Positive values under DEFL are northward or eastward deflections; negative values indicate south ward or westward movement since installation in 1964. 


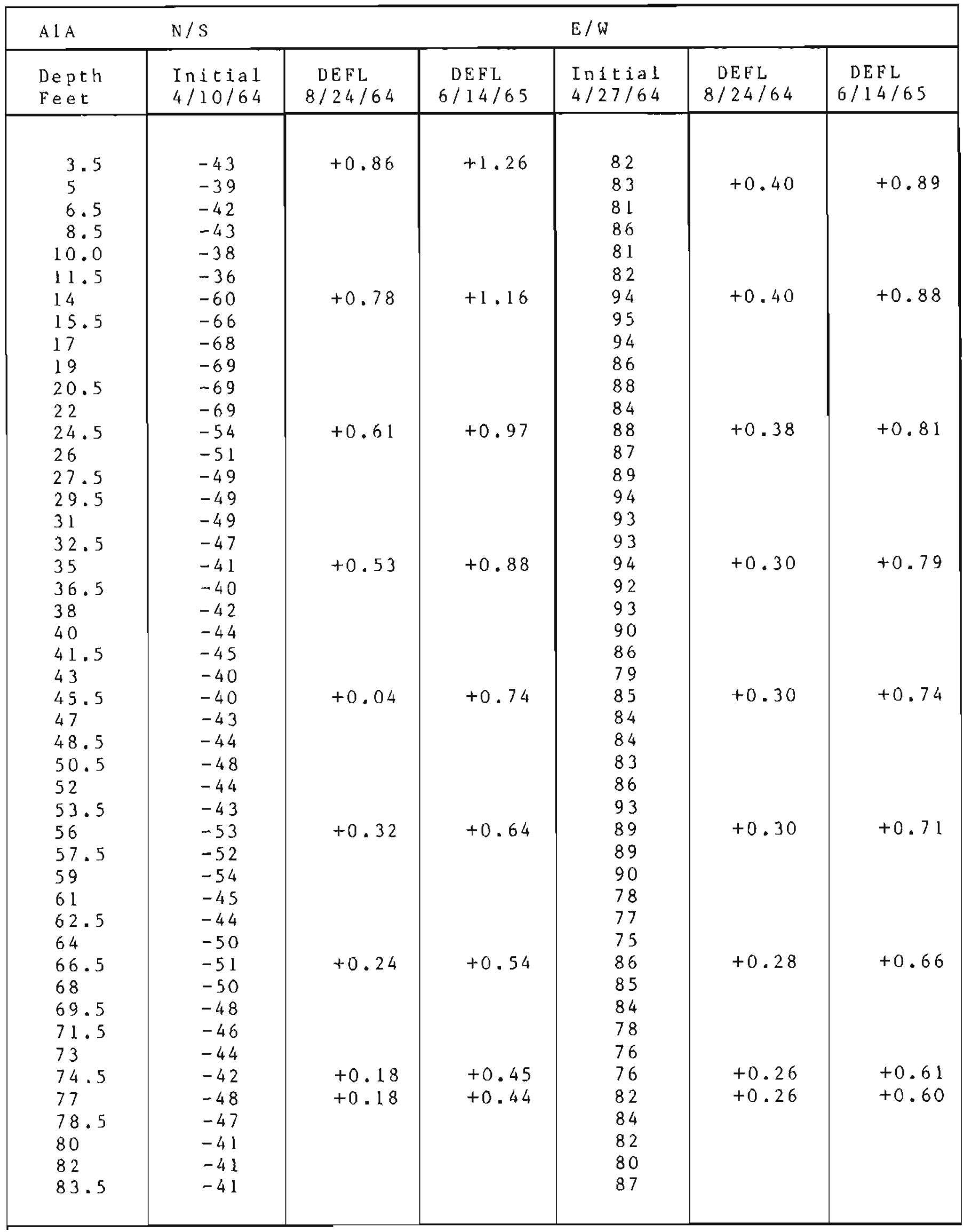


INCLNOMETER STRAIN ANALYSES OH ANCHORAGE LANDSLIDES, 1965.80

\begin{tabular}{|c|c|c|c|c|c|c|}
\hline$A \perp A$ & $\mathrm{~N} / \mathrm{S}$ & & & $E / w$ & & \\
\hline $\begin{array}{l}\text { Depth } \\
\text { Feet }\end{array}$ & $\begin{array}{l}\text { Initial } \\
4 / 10 / 64\end{array}$ & $\begin{array}{c}\text { DEFL } \\
8 / 24 / 64\end{array}$ & $\begin{array}{l}\text { DEFL } \\
6 / 14 / 65\end{array}$ & $\begin{array}{l}\text { Inteial } \\
4 / 27 / 64\end{array}$ & $\begin{array}{c}\text { DEFL } \\
8 / 24 / 64\end{array}$ & $\begin{array}{c}\text { DEFL } \\
6 / 14 / 65\end{array}$ \\
\hline $\begin{array}{l}85 \\
87.5 \\
89 \\
90.5 \\
92.5 \\
94 \\
95.5 \\
98 \\
99.5 \\
101 \\
103 \\
104.5 \\
106 \\
108.5 \\
110 \\
111.5 \\
113.5 \\
115 \\
116.5 \\
119 \\
120.5 \\
122 \\
124 \\
125.5 \\
127 \\
129.5 \\
131 \\
132.5 \\
134.5 \\
136 \\
137.5 \\
140 \\
141.5 \\
143 \\
145 \\
146.5 \\
148 \\
150.5 \\
152\end{array}$ & $\begin{array}{l}-44 \\
-40 \\
-40 \\
-38 \\
-41 \\
-41 \\
-42 \\
-53 \\
-53 \\
-52 \\
-46 \\
-48 \\
-50 \\
-48 \\
-48 \\
-52 \\
-54 \\
-51 \\
-50 \\
-48 \\
-50 \\
-48 \\
-41 \\
-40 \\
-40 \\
-45 \\
-46 \\
-56 \\
-57 \\
-56 \\
-56 \\
-65 \\
-59 \\
-49 \\
-45 \\
-47 \\
-48 \\
-40 \\
-47\end{array}$ & $\begin{array}{l}+0.16 \\
+0.04 \\
-0.05 \\
-0.11 \\
-0.07 \\
-0.09 \\
-0.13\end{array}$ & $\begin{array}{l}+0.40 \\
+0.23 \\
+0.11 \\
+0.04 \\
-0.05 \\
-0.05 \\
-0.03\end{array}$ & $\begin{array}{l}84 \\
88 \\
86 \\
85 \\
86 \\
82 \\
67 \\
73 \\
73 \\
73 \\
71 \\
68 \\
66 \\
67 \\
63 \\
62 \\
67 \\
68 \\
69 \\
82 \\
79 \\
81 \\
77 \\
77 \\
73 \\
73 \\
71 \\
69 \\
70 \\
67 \\
64 \\
69 \\
77 \\
77 \\
68 \\
84 \\
73 \\
65 \\
57\end{array}$ & $\begin{array}{l}+0.10 \\
+0.04 \\
+0.03 \\
+0.03 \\
+-.01\end{array}$ & $\begin{array}{l}+0.31 \\
+0.28 \\
+0.18 \\
+0.08 \\
+0.02\end{array}$ \\
\hline
\end{tabular}




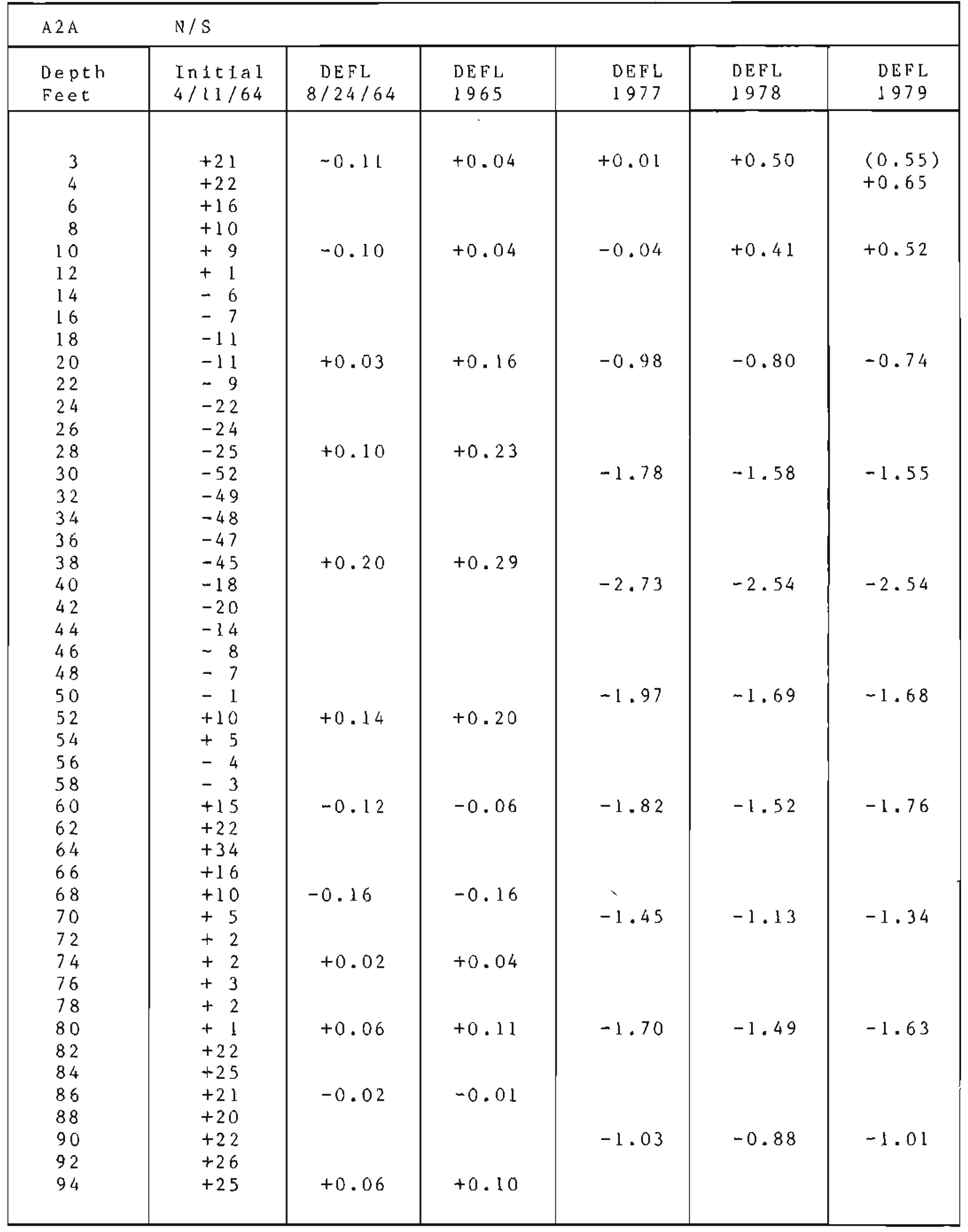




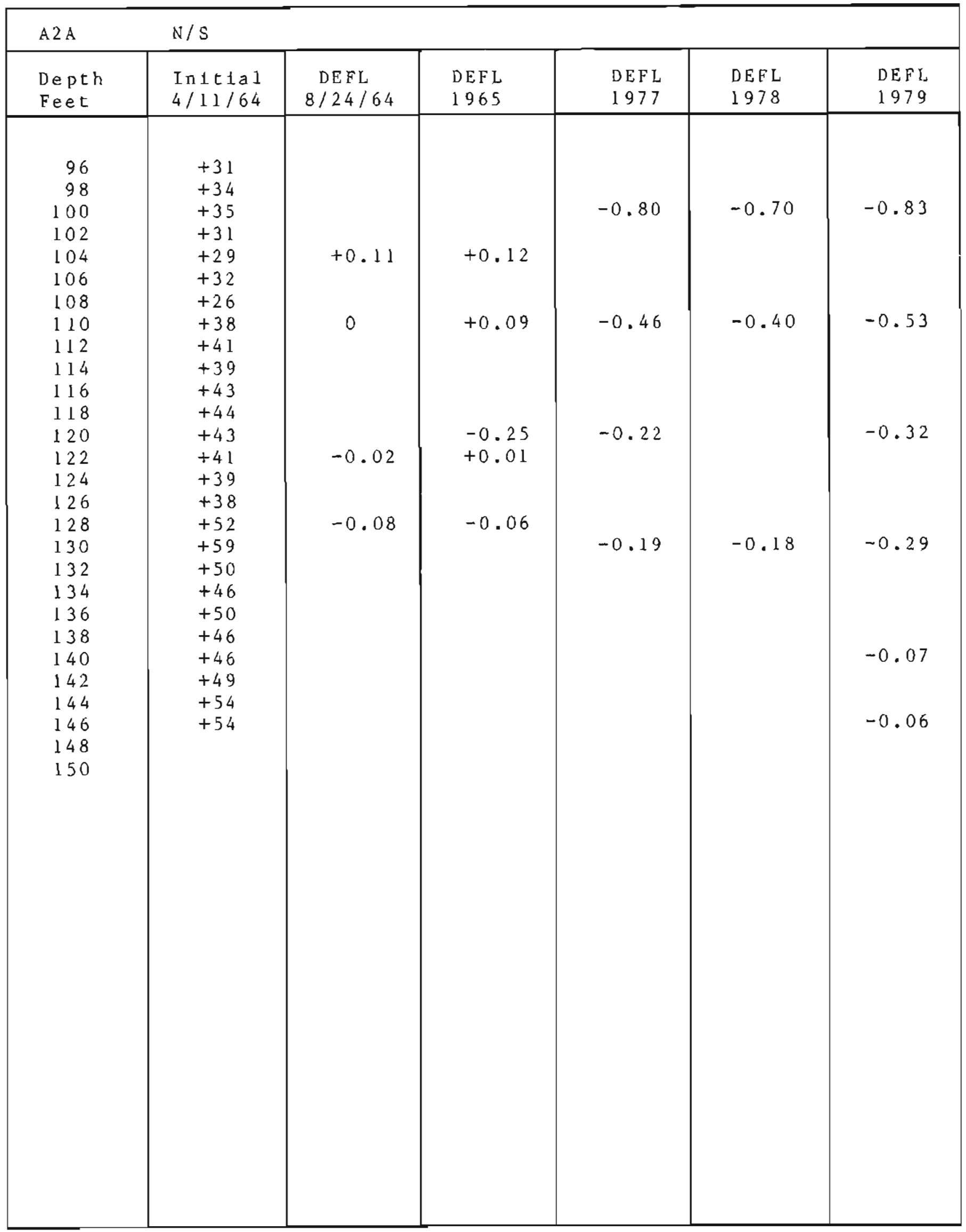




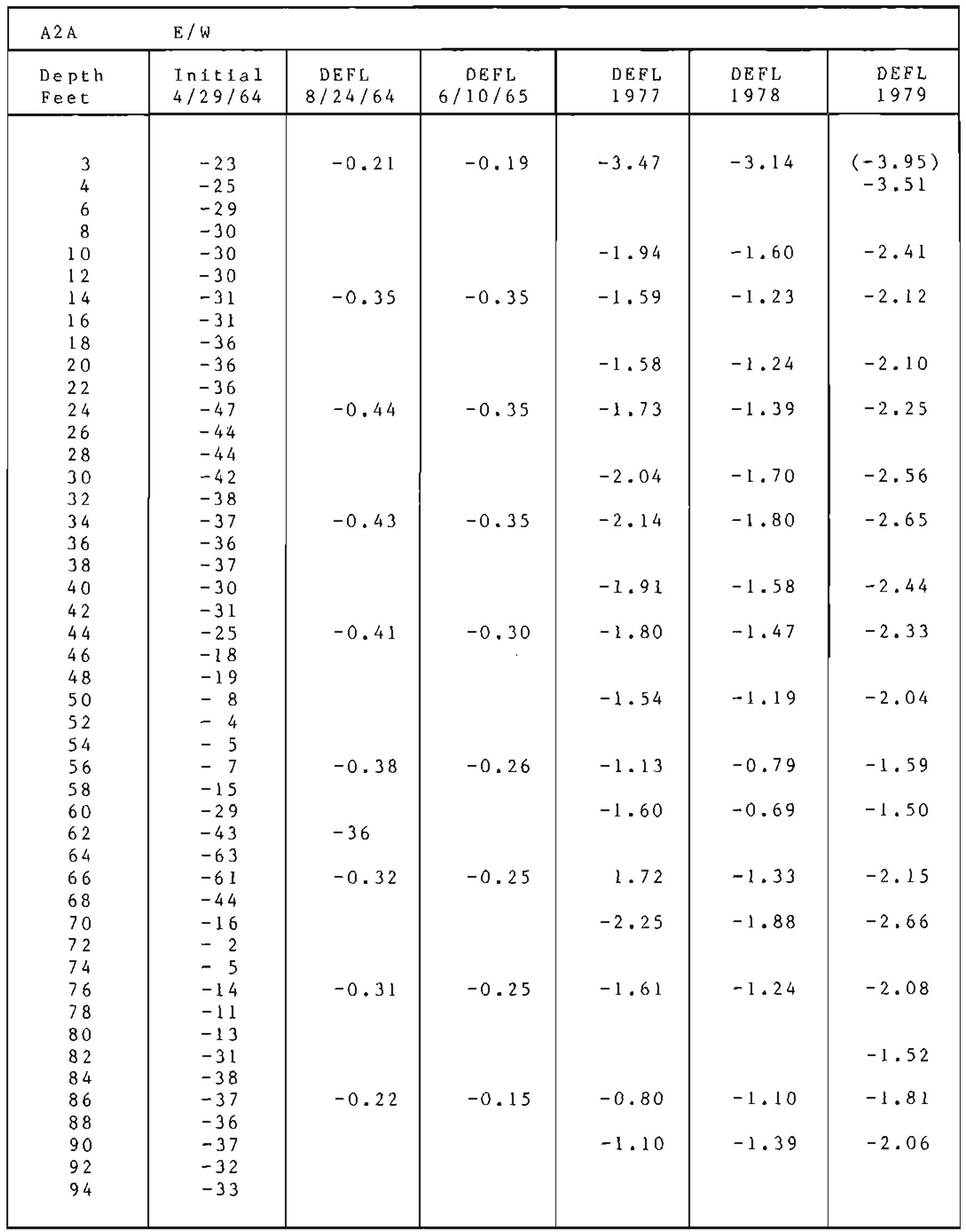




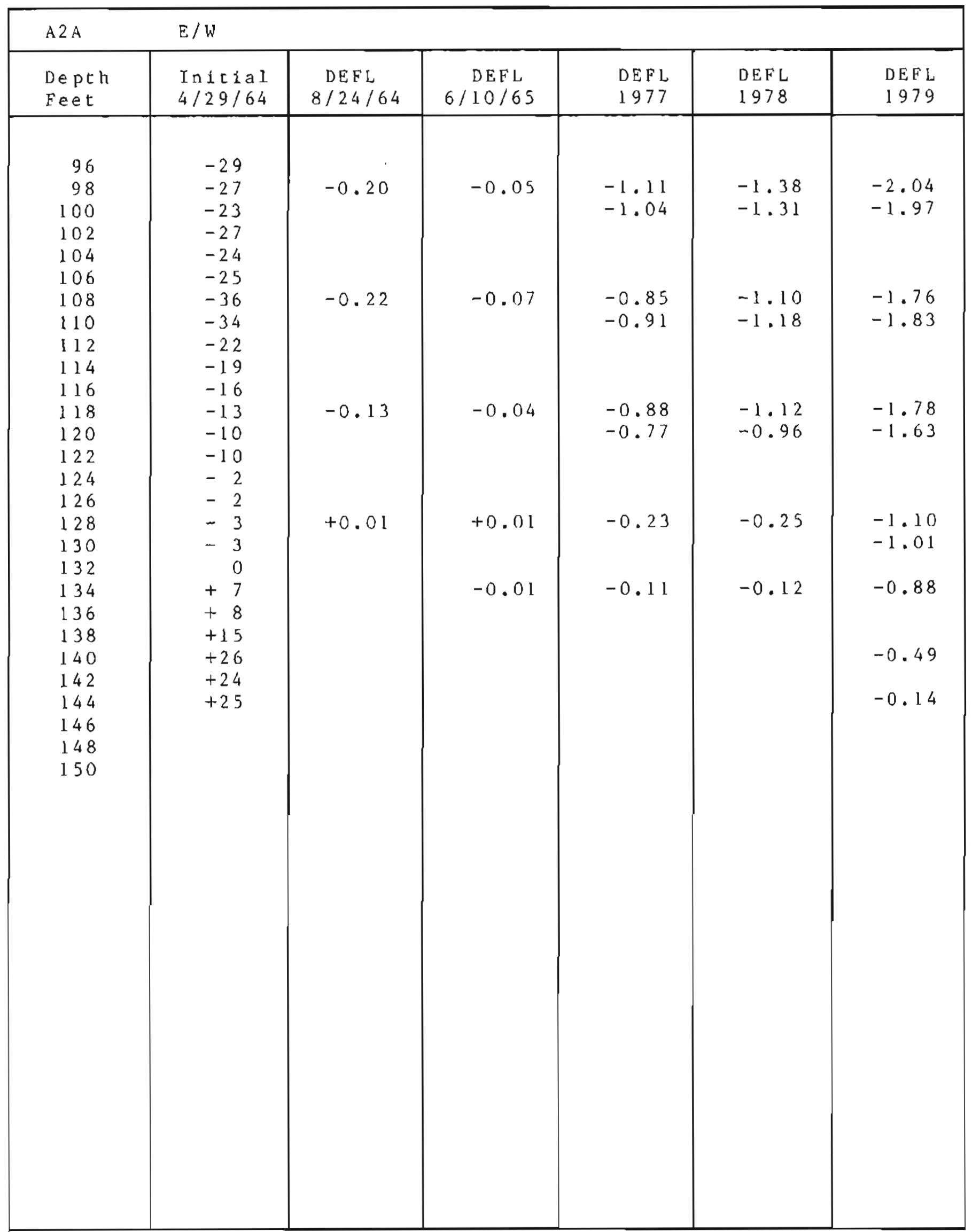




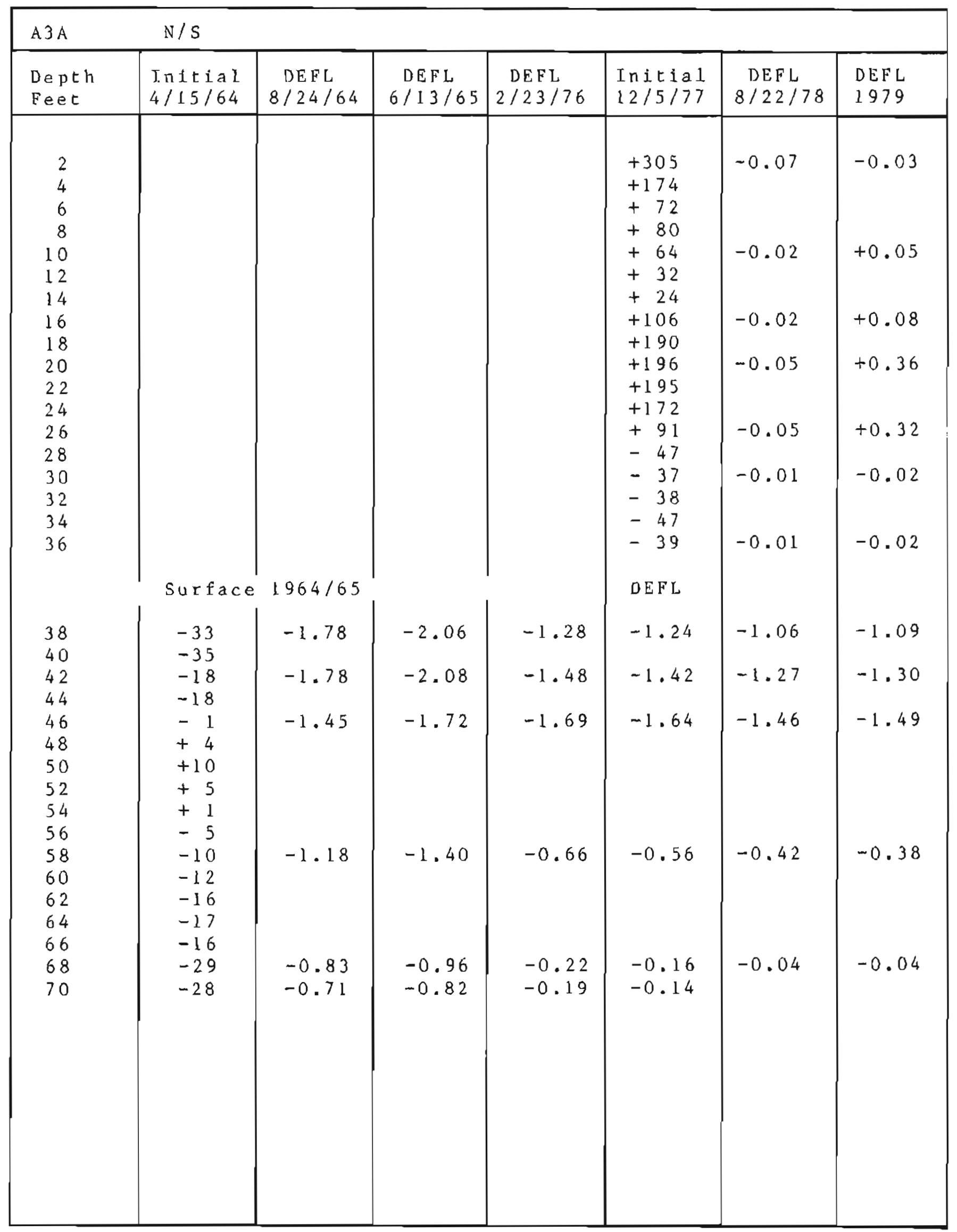




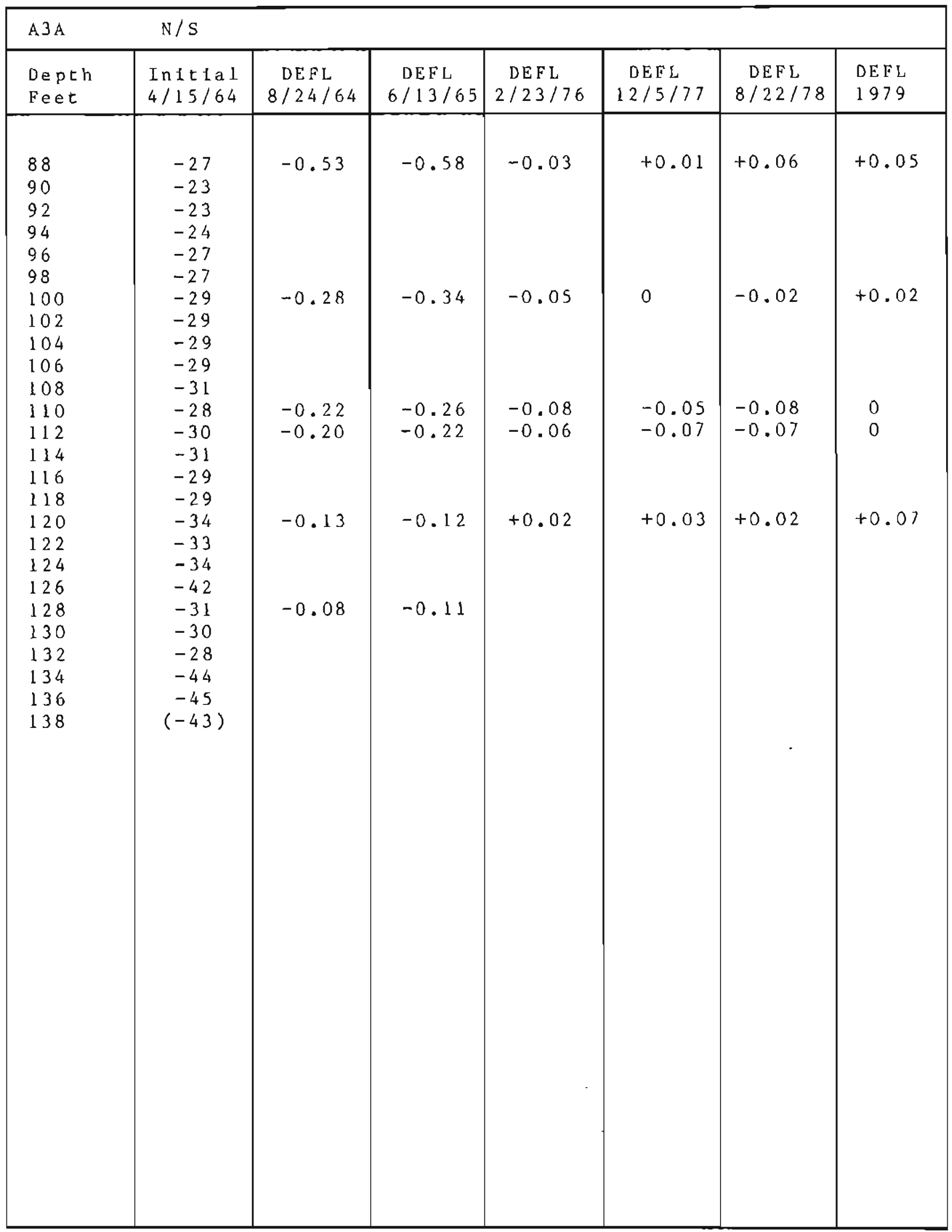




\begin{tabular}{|c|c|c|c|c|c|c|c|}
\hline A $3 \mathrm{~A}$ & $E / W$ & & & & & & \\
\hline $\begin{array}{l}\text { Depth } \\
\text { Feet }\end{array}$ & $\begin{array}{l}\text { Initial } \\
5 / 1 / 64\end{array}$ & $\begin{array}{c}\text { DEFL } \\
8 / 24 / 64\end{array}$ & $\begin{array}{l}\text { DEFL } \\
6 / 13 / 65\end{array}$ & $\begin{array}{c}\text { DEFL } \\
2 / 23 / 76\end{array}$ & $\begin{array}{l}\text { Inftelat } \\
12 / 5 / 77\end{array}$ & $\begin{array}{c}\text { DEFL } \\
8 / 22 / 78\end{array}$ & $\begin{array}{l}\text { DEFL } \\
1979\end{array}$ \\
\hline $\begin{array}{l}2 \\
4 \\
6 \\
8 \\
10 \\
12 \\
14 \\
16 \\
18 \\
20 \\
22 \\
24 \\
26 \\
28 \\
30 \\
32 \\
34 \\
36\end{array}$ & & surface & $1964 / 19$ & & $\begin{array}{l}-239 \\
-135 \\
-\quad 4 \\
+\quad 30 \\
+35 \\
+\quad 20 \\
-11 \\
-61 \\
-72 \\
-74 \\
-\quad 59 \\
-\quad 26 \\
-\quad 38 \\
-74 \\
-76 \\
-\quad 64 \\
-\quad 59 \\
-\quad 62 \\
\text { DEFL }\end{array}$ & $\begin{array}{l}-0.20 \\
-0.17 \\
-0.05 \\
+0.01\end{array}$ & $\begin{array}{l}+0.16 \\
+0.14 \\
+0.06\end{array}$ \\
\hline $\begin{array}{l}38 \\
40 \\
42\end{array}$ & $\begin{array}{l}-90 \\
-90 \\
-76\end{array}$ & +0.72 & +0.67 & +2.71 & +2.81 & +2.70 & +2.62 \\
\hline $\begin{array}{l}44 \\
46 \\
48 \\
50 \\
52 \\
54\end{array}$ & $\begin{array}{l}-79 \\
-78 \\
-79 \\
-78 \\
-76 \\
-74\end{array}$ & +0.55 & +0.50 & +2.60 & +2.71 & +2.63 & +2.53 \\
\hline $\begin{array}{l}56 \\
58 \\
60 \\
62 \\
64\end{array}$ & $\begin{array}{l}-75 \\
-84 \\
-88 \\
-93 \\
-94\end{array}$ & +0.44 & +0.36 & +2.09 & +2.20 & +2.12 & +2.00 \\
\hline $\begin{array}{l}66 \\
68 \\
70 \\
72 \\
74\end{array}$ & $\begin{array}{l}-93 \\
-91 \\
-91 \\
-85 \\
-77\end{array}$ & +0.32 & +0.20 & +1.70 & +1.83 & +1.76 & +1.66 \\
\hline $\begin{array}{l}76 \\
78 \\
80 \\
82 \\
84 \\
86\end{array}$ & $\begin{array}{l}-80 \\
-82 \\
-82 \\
-83 \\
-66 \\
-66\end{array}$ & $\begin{array}{l}+0.21 \\
+0.19\end{array}$ & $\begin{array}{l}+0.14 \\
+0.16\end{array}$ & $\begin{array}{l}+1.39 \\
+1.09\end{array}$ & $\begin{array}{l}+1.50 \\
+1.19\end{array}$ & $\begin{array}{l}+1.43 \\
+1.13\end{array}$ & $\begin{array}{l}+1.36 \\
+1.04\end{array}$ \\
\hline
\end{tabular}




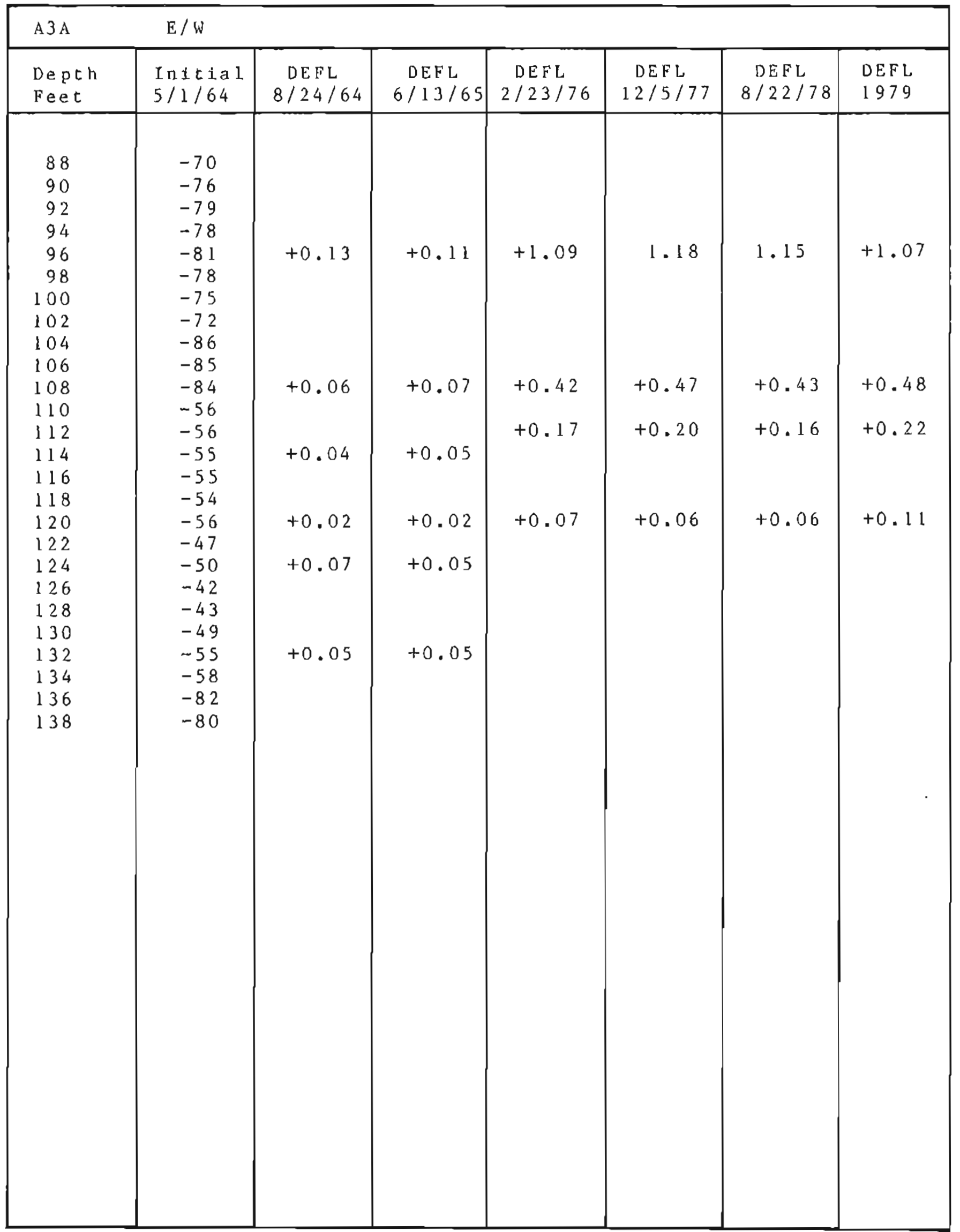




\begin{tabular}{|c|c|c|c|c|c|c|}
\hline $\mathrm{A} 4 \mathrm{~A}$ & $\mathrm{~N} / \mathrm{S}$ & & & $E / W$ & & \\
\hline $\begin{array}{l}\text { Depth } \\
\text { Feet }\end{array}$ & $\begin{array}{l}\text { Intelal } \\
4 / 17 / 64\end{array}$ & $\begin{array}{c}\text { DEFL } \\
8 / 24 / 64\end{array}$ & $\begin{array}{c}\text { DEFL } \\
6 / 15 / 65\end{array}$ & $\begin{array}{l}\text { Init tal } \\
4 / 22 / 64\end{array}$ & $\begin{array}{c}\text { DEFL } \\
8 / 24 / 64\end{array}$ & $\begin{array}{c}\text { DEFL } \\
6 / 15 / 64\end{array}$ \\
\hline $\begin{array}{l}3 \\
4.5 \\
6 \\
8 \\
9.5 \\
11 \\
13.5 \\
15 \\
16.5 \\
18.5 \\
20 \\
21.5 \\
24 \\
25.5 \\
27 \\
29 \\
30.5 \\
32 \\
34.5 \\
36 \\
37.5 \\
39.5 \\
41 \\
42.5 \\
45 \\
46.5 \\
48 \\
50 \\
51.5 \\
53 \\
55.5 \\
57 \\
58.5 \\
60.5 \\
62 \\
63.5 \\
66 \\
67.5 \\
69 \\
71 \\
72.5 \\
74 \\
76.5 \\
78 \\
79.5 \\
81.5 \\
83\end{array}$ & $\begin{array}{r}17 \\
15 \\
13 \\
9 \\
9 \\
10 \\
22 \\
17 \\
19 \\
21 \\
27 \\
28 \\
17 \\
24 \\
26 \\
24 \\
28 \\
29 \\
30 \\
30 \\
30 \\
30 \\
33 \\
33 \\
32 \\
28 \\
30 \\
28 \\
28 \\
27 \\
26 \\
28 \\
31 \\
33 \\
33 \\
34 \\
27 \\
17 \\
23 \\
22 \\
19 \\
13 \\
26 \\
30 \\
27 \\
23 \\
27\end{array}$ & $\begin{array}{l}+1.63 \\
+1.46 \\
+1.29 \\
+1.17 \\
+0.71 \\
+0.68 \\
+0.83 \\
+1.04\end{array}$ & $\begin{array}{l}+1.08 \\
+0.95 \\
+0.90 \\
+0.78 \\
+0.43 \\
+0.40 \\
+0.64 \\
+0.67\end{array}$ & $\begin{array}{r}73 \\
76 \\
78 \\
81 \\
83 \\
83 \\
112 \\
111 \\
111 \\
114 \\
109 \\
107 \\
110 \\
111 \\
110 \\
108 \\
108 \\
107 \\
109 \\
109 \\
109 \\
105 \\
105 \\
105 \\
105 \\
105 \\
105 \\
101 \\
97 \\
94 \\
107 \\
106 \\
106 \\
100 \\
98 \\
98 \\
92 \\
78 \\
81 \\
82 \\
80 \\
81 \\
81 \\
81 \\
84 \\
81 \\
83\end{array}$ & $\begin{array}{l}-0.40 \\
-0.33 \\
-0.27\end{array}$ & $\begin{array}{l}-0.31 \\
-0.28\end{array}$ \\
\hline
\end{tabular}


INCLINOMETER STRAIN ANALYSES OF ANCHORAGE LANDSLIDES, 1965.80

\begin{tabular}{|c|c|c|c|c|c|c|}
\hline $\mathrm{A} 4 \mathrm{~A}$ & $\mathrm{~N} / \mathrm{S}$ & & & $E / W$ & & \\
\hline $\begin{array}{l}\text { Depth } \\
\text { Feet }\end{array}$ & $\begin{array}{l}\text { Initial } \\
4 / 17 / 64\end{array}$ & $\begin{array}{c}\text { DEFL } \\
8 / 24 / 64\end{array}$ & $\begin{array}{c}\text { DEFL } \\
6 / 15 / 65\end{array}$ & $\begin{array}{l}\operatorname{Initial} \\
4 / 22 / 64\end{array}$ & $\begin{array}{c}\text { DEFL } \\
8 / 24 / 64\end{array}$ & $\begin{array}{l}\text { DEFL } \\
6 / 15 / 64\end{array}$ \\
\hline $\begin{array}{l}84.5 \\
87 \\
88.5 \\
90 \\
92 \\
93.5 \\
95 \\
97.5 \\
99 \\
100.5 \\
102.5 \\
104 \\
105.5 \\
108 \\
109.5 \\
111 \\
113 \\
114.5 \\
116 \\
118.5 \\
120 \\
121.5 \\
123.5 \\
125 \\
126.5 \\
129 \\
130.5 \\
132 \\
134 \\
135.5 \\
137 \\
139.5 \\
141 \\
142.5 \\
144.5 \\
146 \\
147.5\end{array}$ & $\begin{array}{l}25 \\
19 \\
23 \\
27 \\
29 \\
29 \\
28 \\
28 \\
27 \\
26 \\
24 \\
24 \\
22 \\
31 \\
31 \\
31 \\
29 \\
29 \\
26 \\
24 \\
28 \\
27 \\
28 \\
28 \\
28 \\
17 \\
23 \\
27 \\
27 \\
27 \\
25 \\
12 \\
10 \\
11 \\
13 \\
14 \\
17\end{array}$ & $\begin{array}{l}+0.60 \\
+0.48 \\
+0.39 \\
+0.26 \\
+0.19\end{array}$ & $\begin{array}{l}+0.44 \\
+0.35 \\
+0.31 \\
+0.27 \\
+0.19 \\
+07\end{array}$ & $\begin{array}{l}84 \\
76 \\
73 \\
73 \\
69 \\
69 \\
71 \\
76 \\
77 \\
77 \\
76 \\
77 \\
78 \\
83 \\
83 \\
83 \\
82 \\
85 \\
87 \\
81 \\
88 \\
92 \\
87 \\
88 \\
90 \\
80 \\
82 \\
76 \\
74 \\
73 \\
73 \\
75 \\
79 \\
81 \\
79 \\
78 \\
0\end{array}$ & $\begin{array}{l}-0.12 \\
-0.07 \\
-0.02 \\
-0.02\end{array}$ & $\begin{array}{r}-0.13 \\
-0.06 \\
0 \\
-0.02\end{array}$ \\
\hline
\end{tabular}




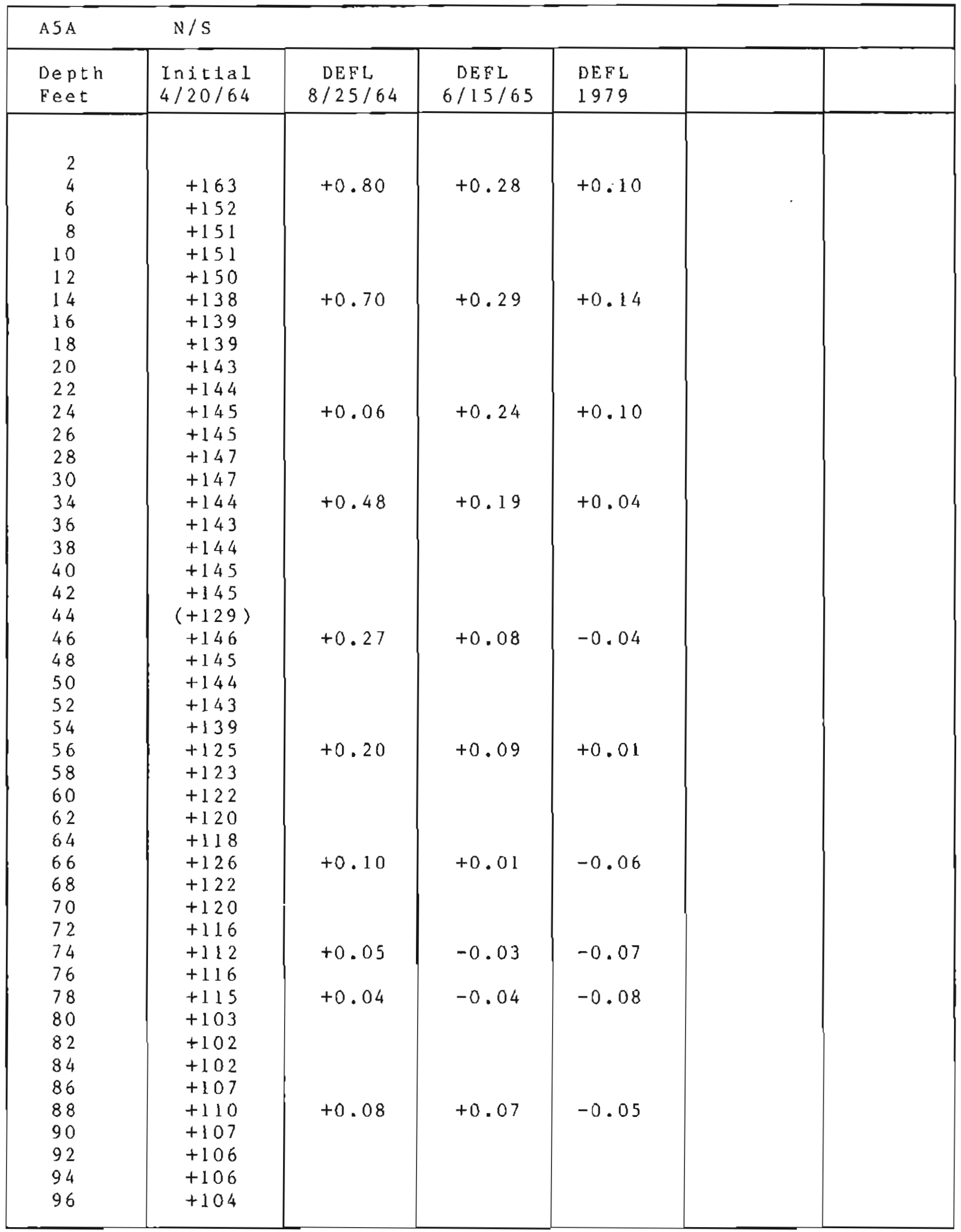




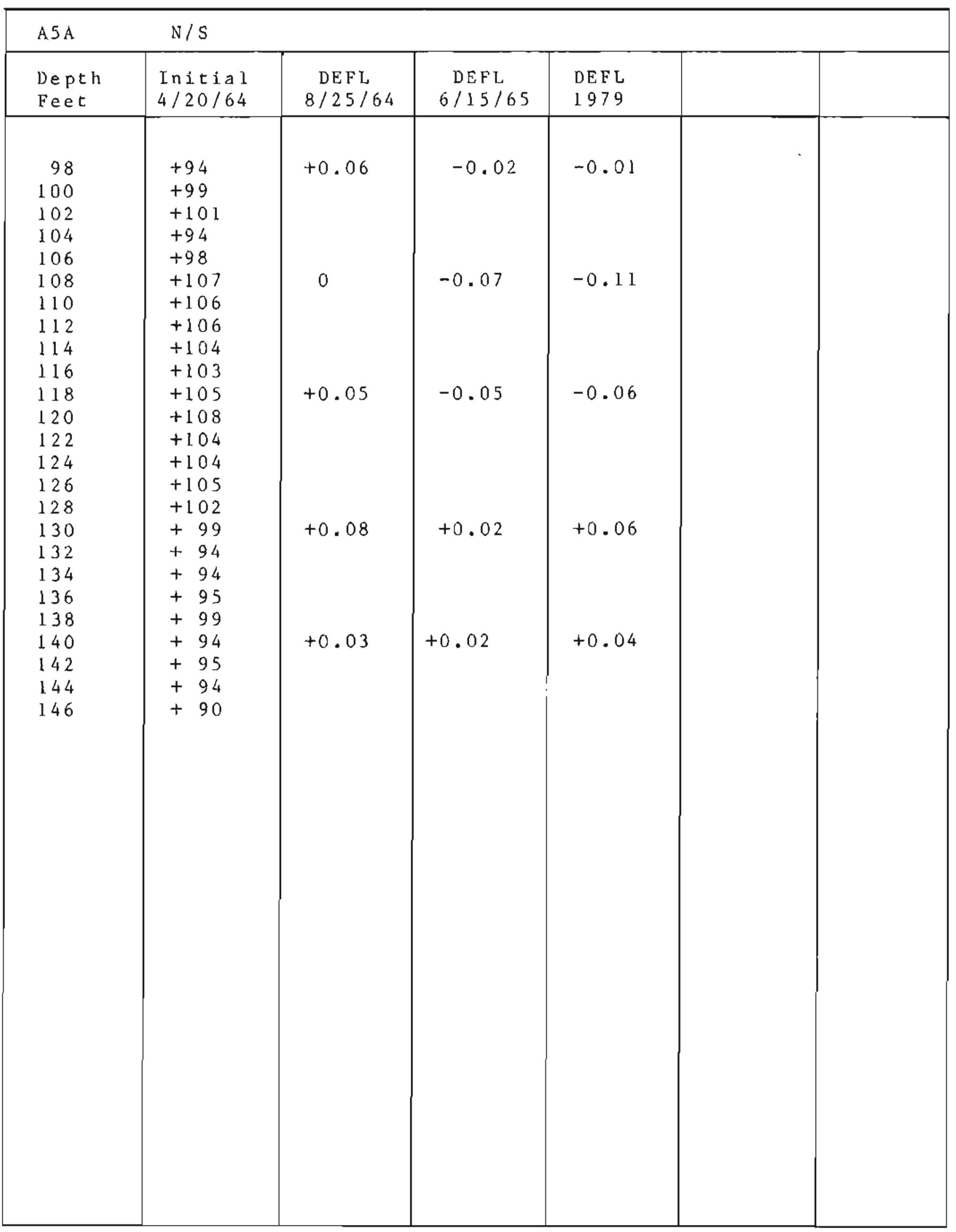




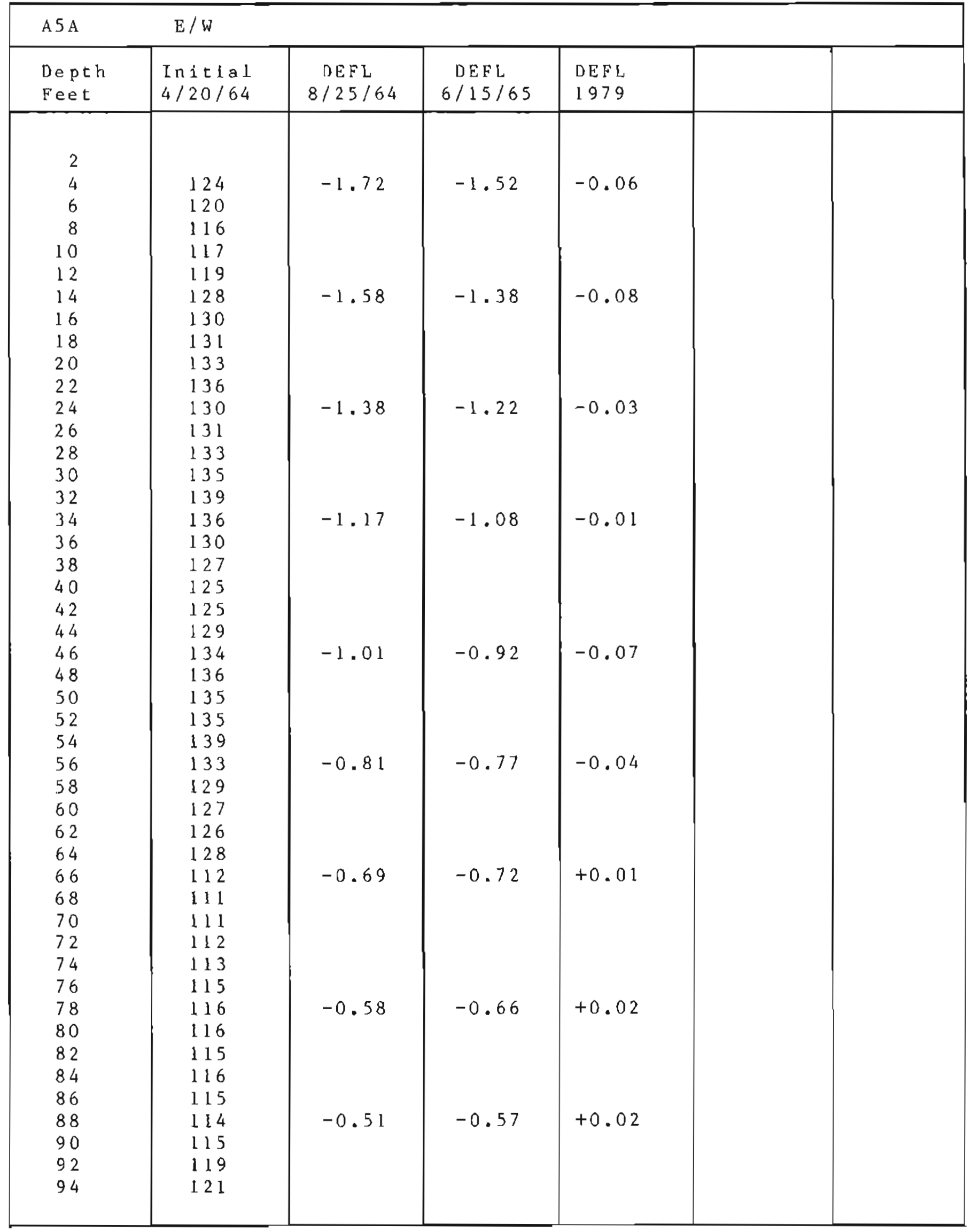


62

INCLINOMETER STRAIN ANALYSES OF ANCHORAGE LANDSLIDES, 1965.80

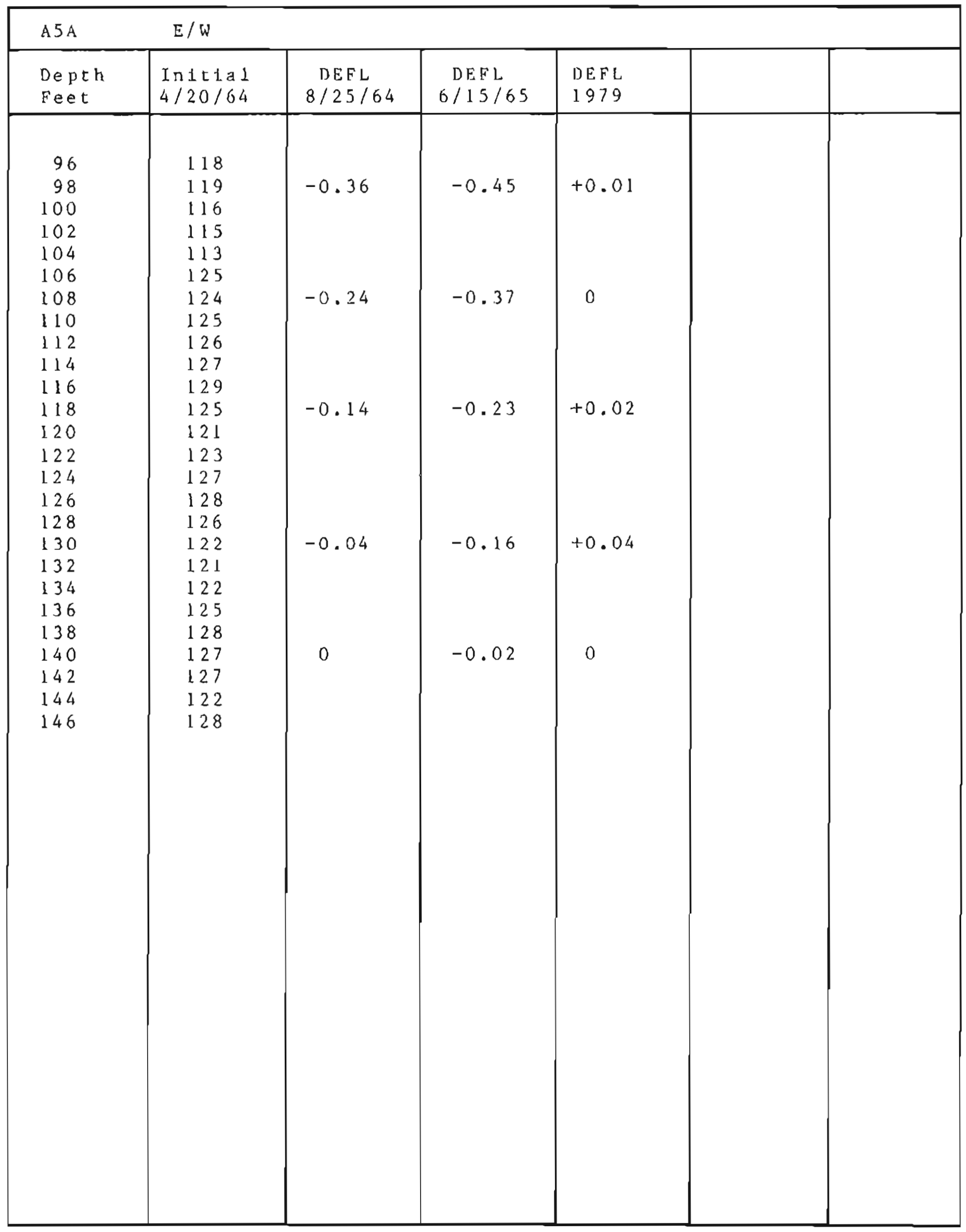




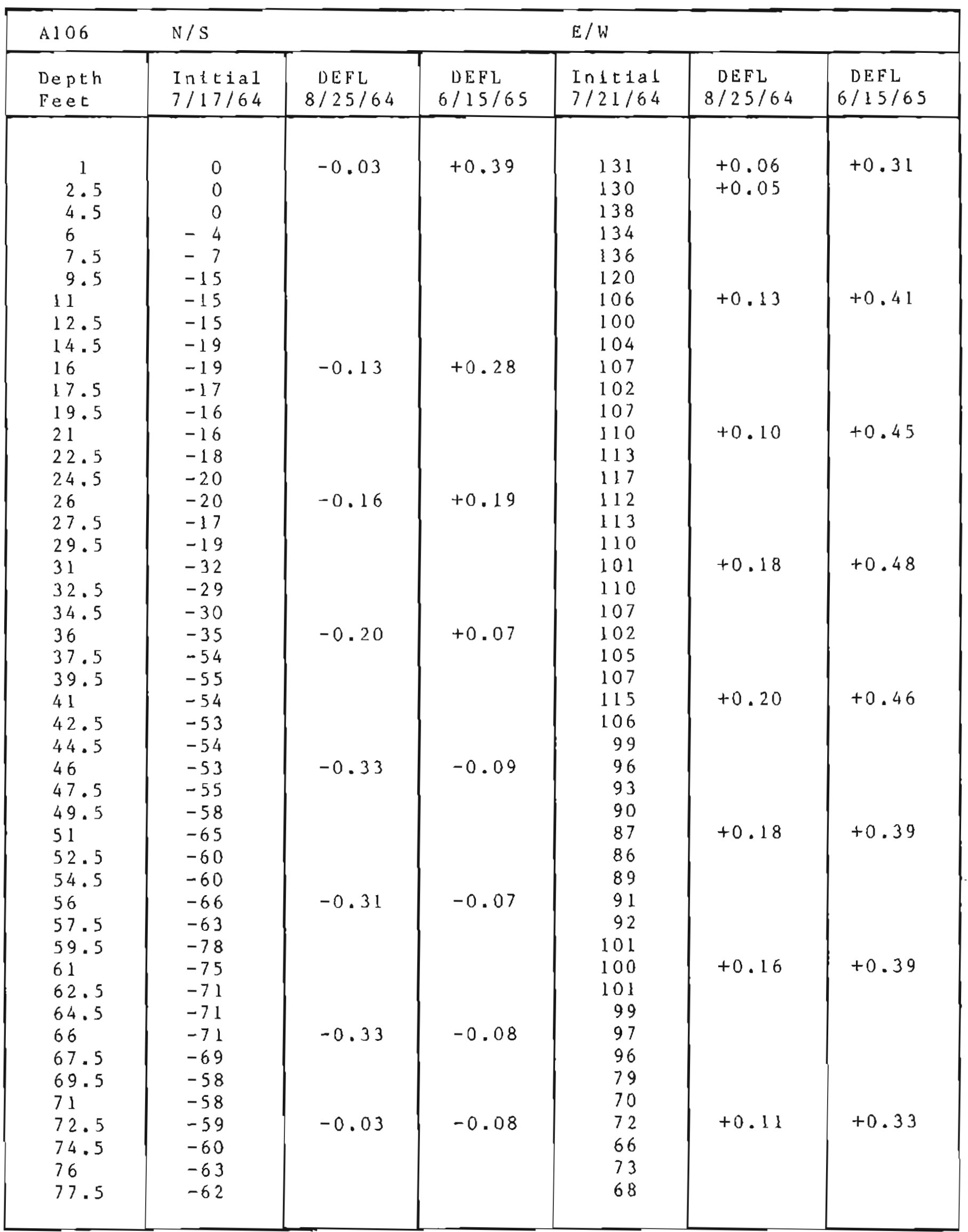




\begin{tabular}{|c|c|c|c|c|c|c|}
\hline$A \perp 06$ & $N / S$ & & & $E / \mathrm{W}$ & & \\
\hline $\begin{array}{l}\text { Depth } \\
\text { Feet }\end{array}$ & $\begin{array}{l}\text { Initial } \\
7 / 17 / 64\end{array}$ & $\begin{array}{c}\text { DEFL } \\
8 / 25 / 64\end{array}$ & $\begin{array}{l}\text { DEFL } \\
6 / 15 / 65\end{array}$ & $\begin{array}{l}\text { Indt } 1 \text { a } 1 \\
7 / 21 / 64\end{array}$ & $\begin{array}{c}\text { DEEL } \\
8 / 25 / 64\end{array}$ & $\begin{array}{c}\text { DEFL } \\
6 / 15 / 65\end{array}$ \\
\hline $\begin{array}{l}79.5 \\
81 \\
82.5 \\
84.5 \\
86 \\
87.5 \\
89.5 \\
91 \\
92.5 \\
94.5 \\
96 \\
97.5 \\
99.5 \\
101 \\
102.5 \\
104.5 \\
106 \\
107.5 \\
109.5 \\
111 \\
112.5 \\
114.5 \\
116 \\
1117.5 \\
119.5 \\
121 \\
1122.5 \\
124.5 \\
1126 \\
1127.5 \\
1129.5 \\
131 \\
132.5 \\
134.5 \\
136 \\
137.5 \\
139.5 \\
141 \\
142.5 \\
144.5 \\
146 \\
147.5 \\
149.5 \\
151 \\
1152.5 \\
154.5 \\
156\end{array}$ & $\begin{array}{l}-57 \\
-57 \\
-57 \\
-57 \\
-57 \\
-62 \\
-65 \\
-65 \\
-66 \\
-68 \\
-68 \\
-72 \\
-53 \\
-53 \\
-53 \\
-53 \\
-51 \\
-49 \\
-19 \\
-24 \\
-27 \\
-27 \\
-32 \\
-38 \\
-65 \\
-57 \\
-53 \\
-52 \\
-52 \\
-49 \\
-31 \\
-30 \\
-30 \\
-30 \\
-30 \\
-30 \\
-23 \\
-26 \\
-26 \\
-22 \\
-28 \\
-27 \\
-10 \\
-5 \\
-59 \\
-29 \\
-59\end{array}$ & 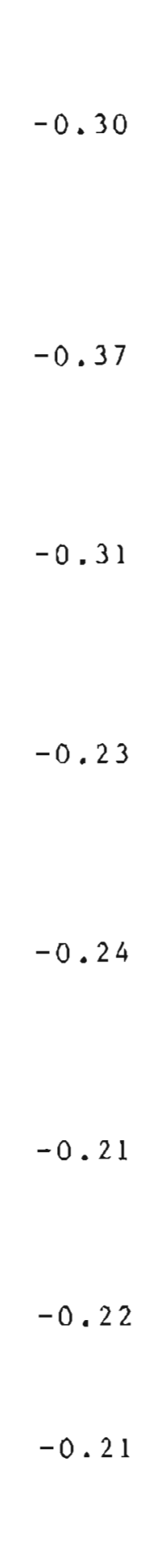 & $\begin{array}{l}-0.11 \\
-0.17 \\
-0.14 \\
-0.08 \\
-0.10 \\
-0.07 \\
-0.13\end{array}$ & $\begin{array}{l}65 \\
64 \\
63 \\
59 \\
56 \\
55 \\
66 \\
69 \\
70 \\
69 \\
67 \\
66 \\
47 \\
43 \\
42 \\
38 \\
36 \\
33 \\
51 \\
51 \\
55 \\
55 \\
56 \\
64 \\
74 \\
76 \\
76 \\
74 \\
74 \\
74 \\
59 \\
56 \\
60 \\
61 \\
60 \\
58 \\
71 \\
74 \\
75 \\
74 \\
76 \\
78 \\
73 \\
67 \\
67 \\
65 \\
65\end{array}$ & $\begin{array}{l}+0.14 \\
+0.08\end{array}$ & $\begin{array}{l}+0.33 \\
+0.20\end{array}$ \\
\hline
\end{tabular}


PROFESSIONAL REPOR'C 80

\begin{tabular}{|c|c|c|c|c|c|c|}
\hline A 106 & $\mathrm{~N} / \mathrm{S}$ & & & $E / h^{\top}$ & & \\
\hline $\begin{array}{l}\text { Depth } \\
\text { Feet }\end{array}$ & $\begin{array}{l}1 \pi 1 t 1 \text { a I } \\
7 / 17 / 64\end{array}$ & $\begin{array}{c}\text { DEFL } \\
8 / 25 / 64\end{array}$ & $\begin{array}{l}\text { DEFL } \\
6 / 15 / 65\end{array}$ & $\begin{array}{l}\text { Initial } \\
7 / 21 / 64\end{array}$ & $\begin{array}{c}\text { DEFL } \\
8 / 25 / 64\end{array}$ & $\begin{array}{c}\text { DEFL } \\
6 / 15 / 65\end{array}$ \\
\hline $\begin{array}{l}157.5 \\
159.5 \\
161 \\
162.5 \\
164.5 \\
166 \\
167.5 \\
169.5 \\
171 \\
172.5 \\
174.5 \\
176 \\
177.5 \\
179.5 \\
181 \\
182.5 \\
184.5 \\
186\end{array}$ & $\begin{array}{l}-14 \\
-25 \\
-28 \\
-27 \\
-25 \\
-26 \\
-27 \\
-25 \\
-25 \\
-25 \\
-26 \\
-26 \\
-26 \\
-27 \\
-29 \\
-30 \\
-30 \\
-30\end{array}$ & $\begin{array}{l}-0.13 \\
-0.07 \\
-0.03\end{array}$ & $\begin{array}{l}-0.04 \\
-0.02 \\
-0.05\end{array}$ & $\begin{array}{l}64 \\
61 \\
61 \\
59 \\
61 \\
61 \\
76 \\
80 \\
81 \\
80 \\
74 \\
71 \\
66 \\
40 \\
37 \\
36 \\
38 \\
38\end{array}$ & $\begin{array}{l}+0.06 \\
+0.01 \\
+0.01\end{array}$ & $\begin{array}{l}+0.10 \\
+0.09 \\
+0.02\end{array}$ \\
\hline
\end{tabular}




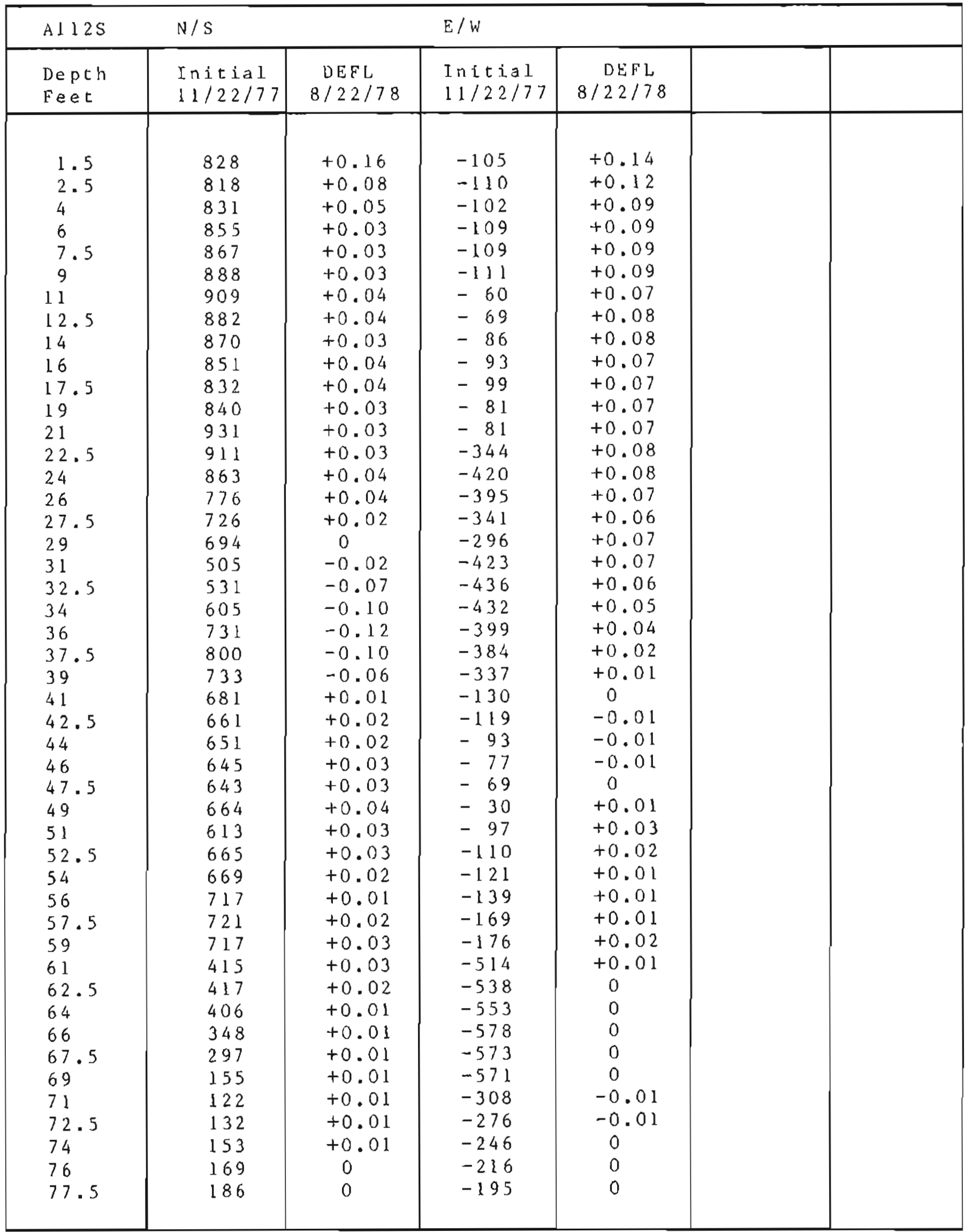




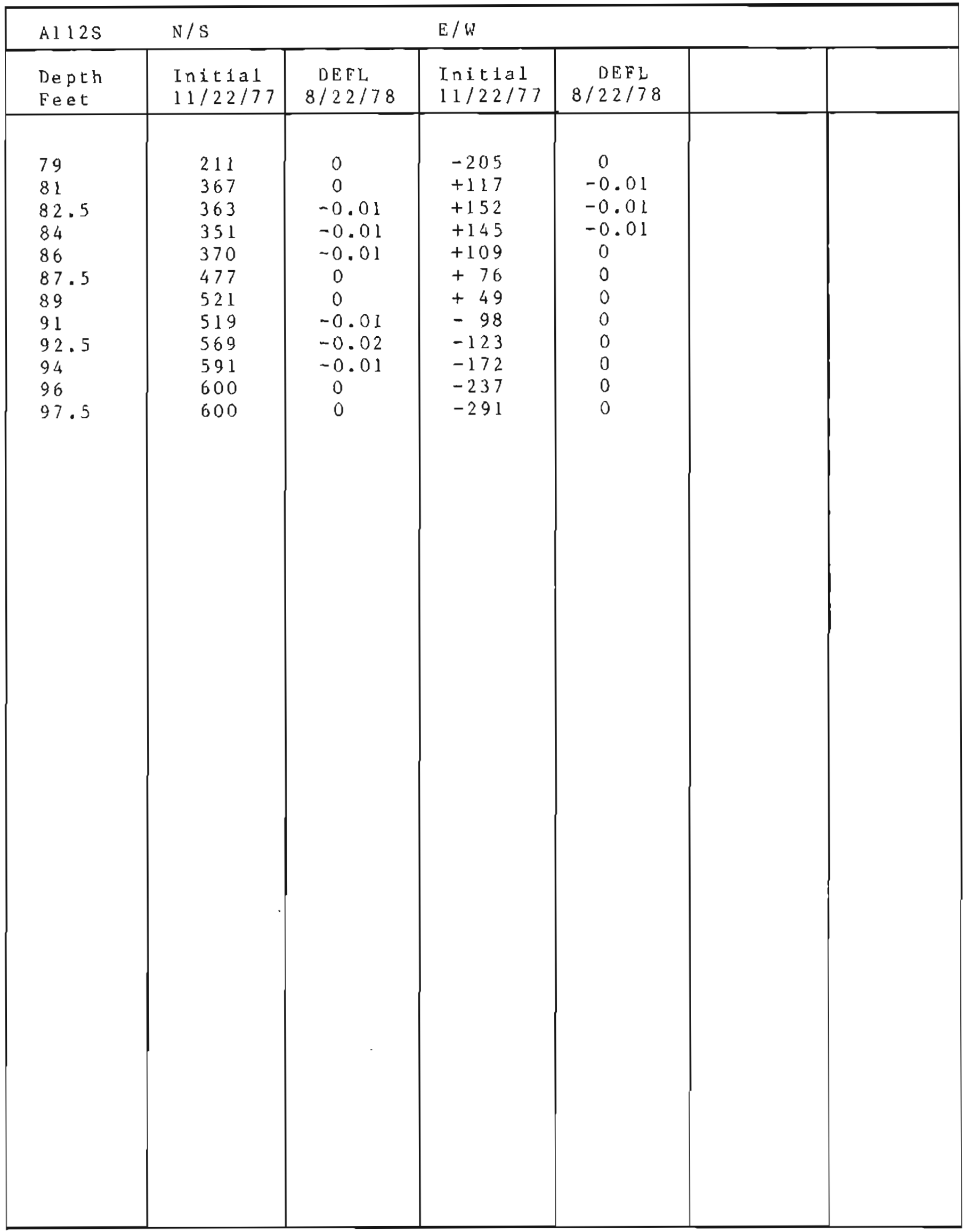




\begin{tabular}{|c|c|c|c|c|c|c|}
\hline Al $1005 \mathrm{~S}$ & $\mathrm{~N} / \mathrm{S}$ & & & $E / W$ & & \\
\hline $\begin{array}{l}\text { Depth } \\
\text { Feet }\end{array}$ & $\begin{array}{l}\text { Init } 1 \text { a } 1 \\
11 / 22 / 77\end{array}$ & $\begin{array}{c}\text { DEFL } \\
8 / 23 / 78\end{array}$ & $\begin{array}{l}\text { DEFL } \\
1979\end{array}$ & $\begin{array}{l}\text { Initial } \\
11 / 22 / 77\end{array}$ & $\begin{array}{c}\text { DEFL } \\
8 / 23 / 78\end{array}$ & $\begin{array}{l}\text { DEFL } \\
1979\end{array}$ \\
\hline $\begin{array}{l}1 \\
3 \\
5 \\
7 \\
9 \\
11 \\
13 \\
15 \\
17 \\
19 \\
21 \\
23 \\
25 \\
27 \\
29 \\
31 \\
33 \\
35 \\
37 \\
39 \\
41 \\
43 \\
45 \\
47 \\
49 \\
51 \\
53 \\
55 \\
57 \\
59 \\
61 \\
63 \\
65 \\
67 \\
69 \\
71 \\
73 \\
75 \\
77\end{array}$ & 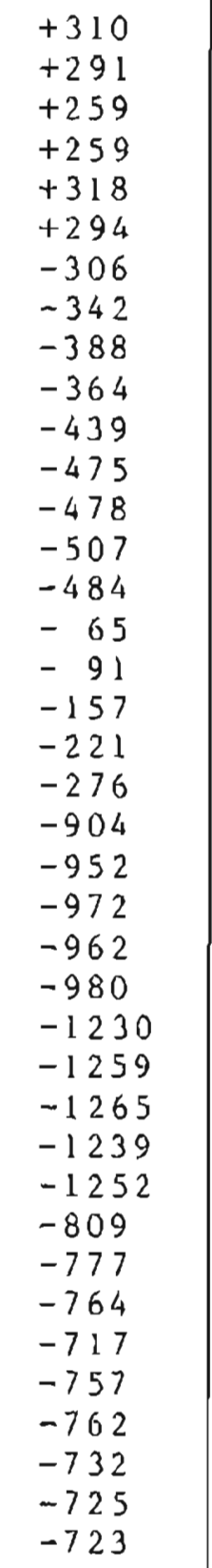 & $\begin{array}{l}-0.07 \\
-0.02 \\
-0.03 \\
0 \\
0 \\
0.02 \\
+0.02\end{array}$ & $\begin{array}{l}+0.01 \\
+0.06 \\
+0.11 \\
-0.07 \\
+0.09 \\
+0.04 \\
+0.09\end{array}$ & $\begin{array}{l}-92 \\
-\quad 97 \\
-115 \\
-136 \\
-163 \\
-\quad 85 \\
-58 \\
-\quad 30 \\
-32 \\
-17 \\
+212 \\
+200 \\
+195 \\
+231 \\
+203 \\
-88 \\
-74 \\
-86 \\
-120 \\
-124 \\
+92 \\
+97 \\
+85 \\
+57 \\
+46 \\
+79 \\
+75 \\
+77 \\
+81 \\
+74 \\
-156 \\
-155 \\
-158 \\
-162 \\
-157 \\
-186 \\
-205 \\
-215 \\
-249\end{array}$ & $\begin{array}{l}-0.02 \\
-0.04 \\
-0.03 \\
+0.05 \\
+0.01\end{array}$ & $\begin{array}{l}+0.11 \\
+0.12 \\
+0.02\end{array}$ \\
\hline
\end{tabular}




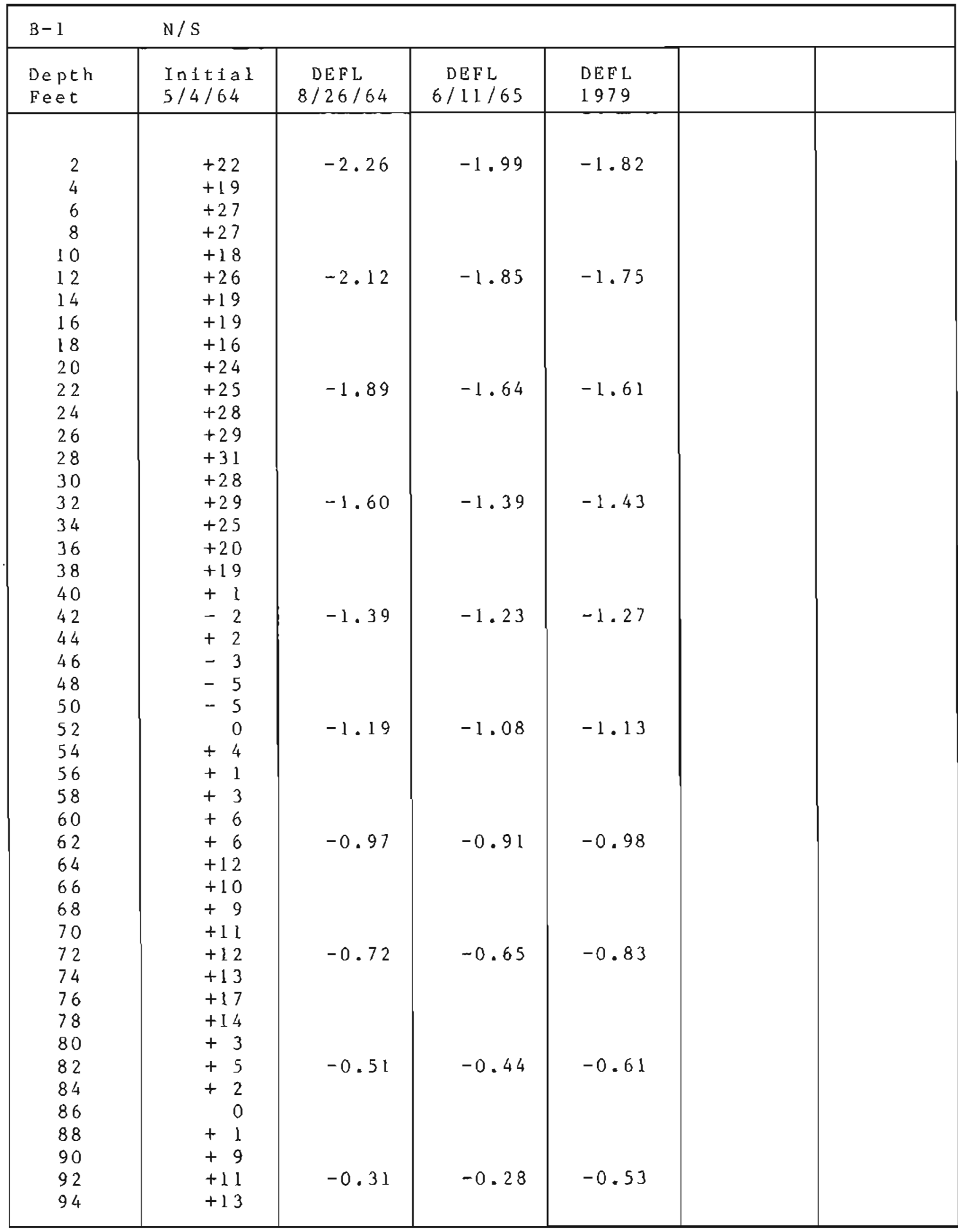




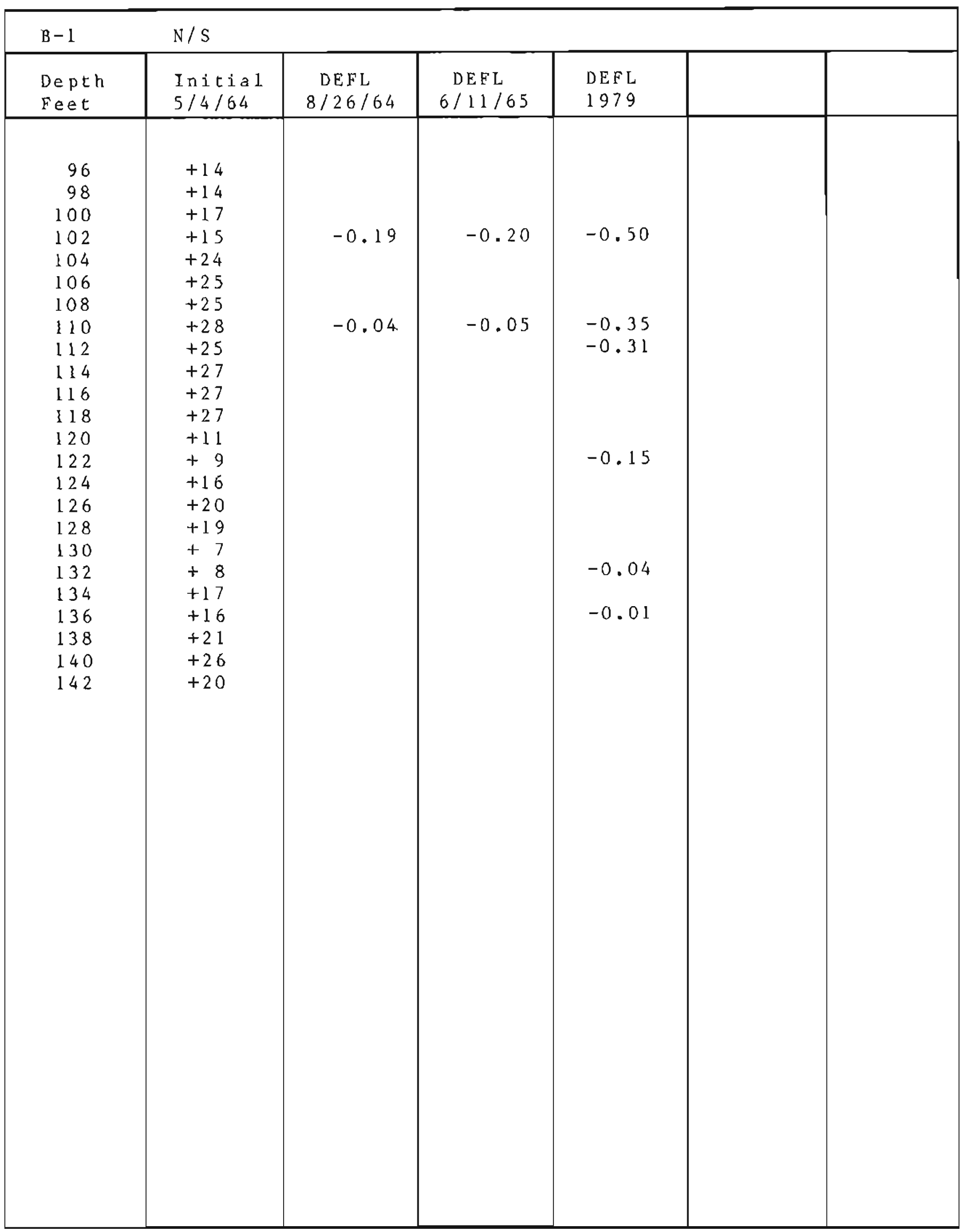




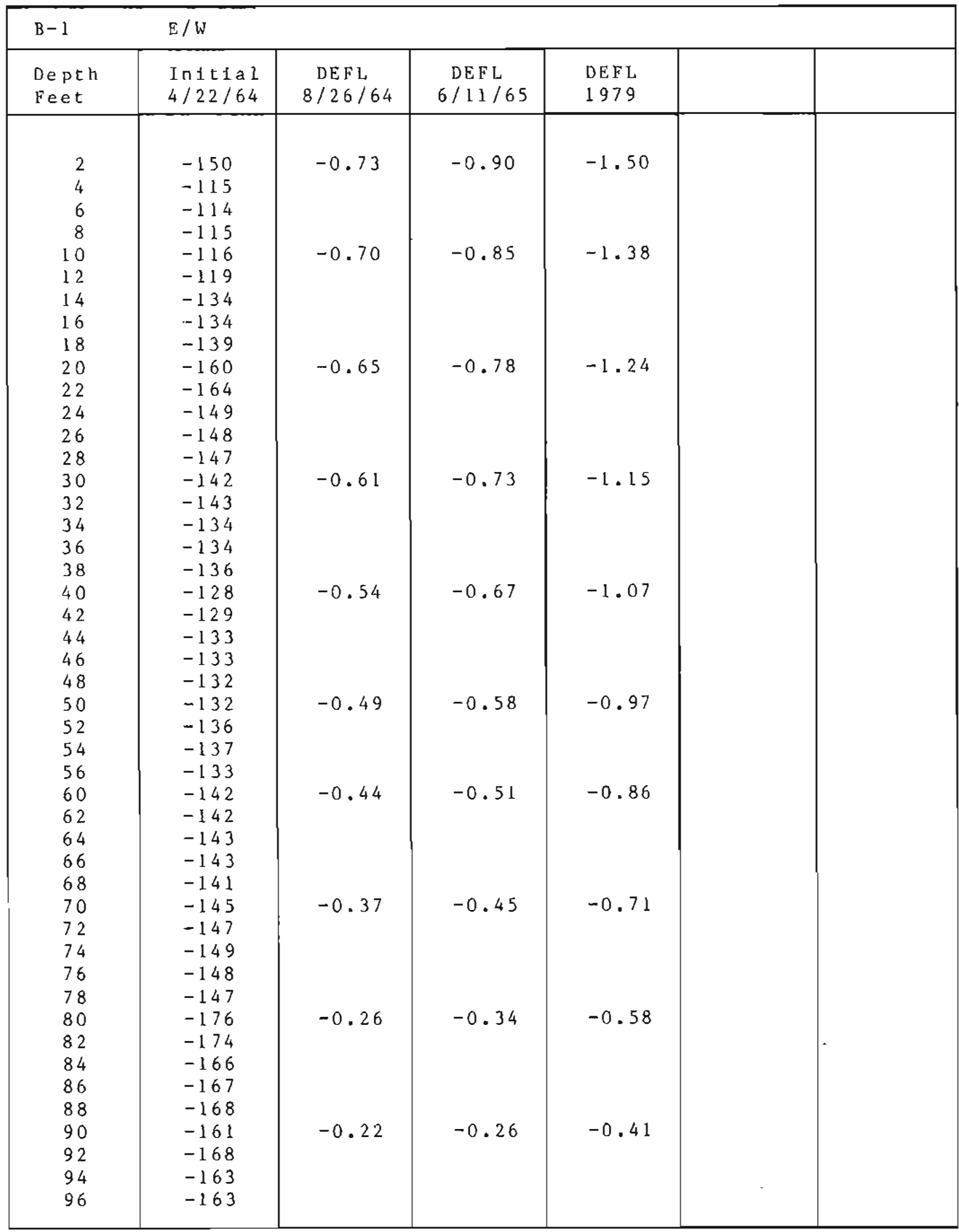


INCLINOMETER STRAIN ANALYSES OF ANCHORAGE LANDSLIDES, 1985-80

\begin{tabular}{|c|c|c|c|c|}
\hline$B-1$ & $E / W$ & & & \\
\hline $\begin{array}{l}\text { Depth } \\
\text { Feet }\end{array}$ & $\begin{array}{l}\text { Initial } \\
4 / 22 / 64\end{array}$ & $\begin{array}{c}\text { DEFL } \\
8 / 26 / 64 \\
\end{array}$ & $\begin{array}{l}\text { DEFL } \\
6 / 11 / 65 \\
\end{array}$ & $\begin{array}{l}\text { DEFL } \\
1979 \\
\end{array}$ \\
\hline $\begin{array}{l}98 \\
100 \\
102 \\
104 \\
106 \\
108 \\
110 \\
112 \\
114 \\
116 \\
118 \\
120 \\
122 \\
124 \\
126 \\
128 \\
130 \\
132 \\
134 \\
136 \\
138 \\
140 \\
142\end{array}$ & $\begin{array}{l}-163 \\
-170 \\
-169 \\
-168 \\
-167 \\
-168 \\
-169 \\
-170 \\
-169 \\
-169 \\
-169 \\
-163 \\
-163 \\
-159 \\
-160 \\
-156 \\
-147 \\
-145 \\
-145 \\
-145 \\
-146 \\
-146 \\
-147\end{array}$ & $\begin{array}{l}-0.14 \\
-0.02\end{array}$ & $\begin{array}{l}-0.15 \\
-0.02\end{array}$ & $\begin{array}{l}-0.31 \\
-0.16 \\
-0.10 \\
-0.08 \\
-0.02\end{array}$ \\
\hline
\end{tabular}




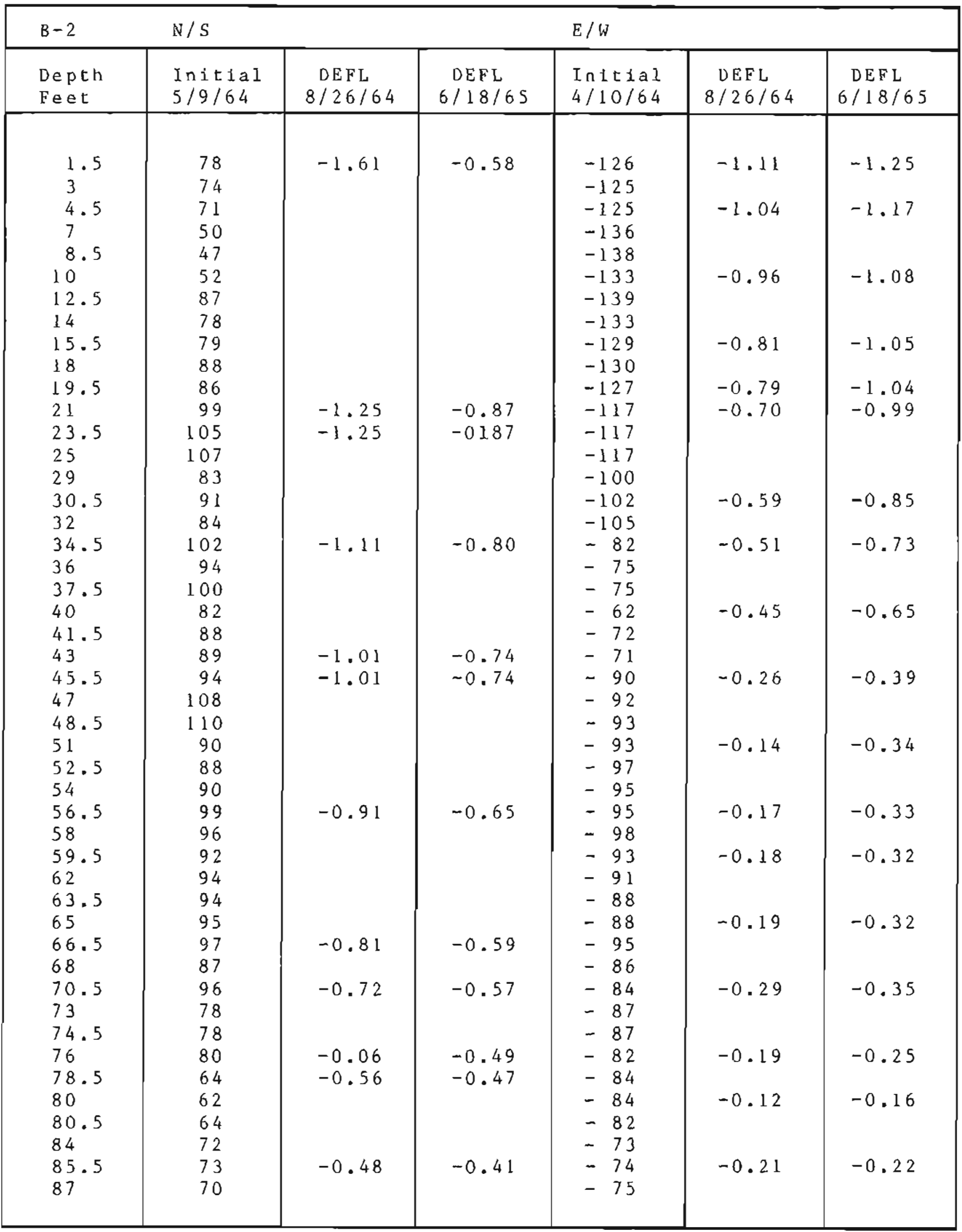




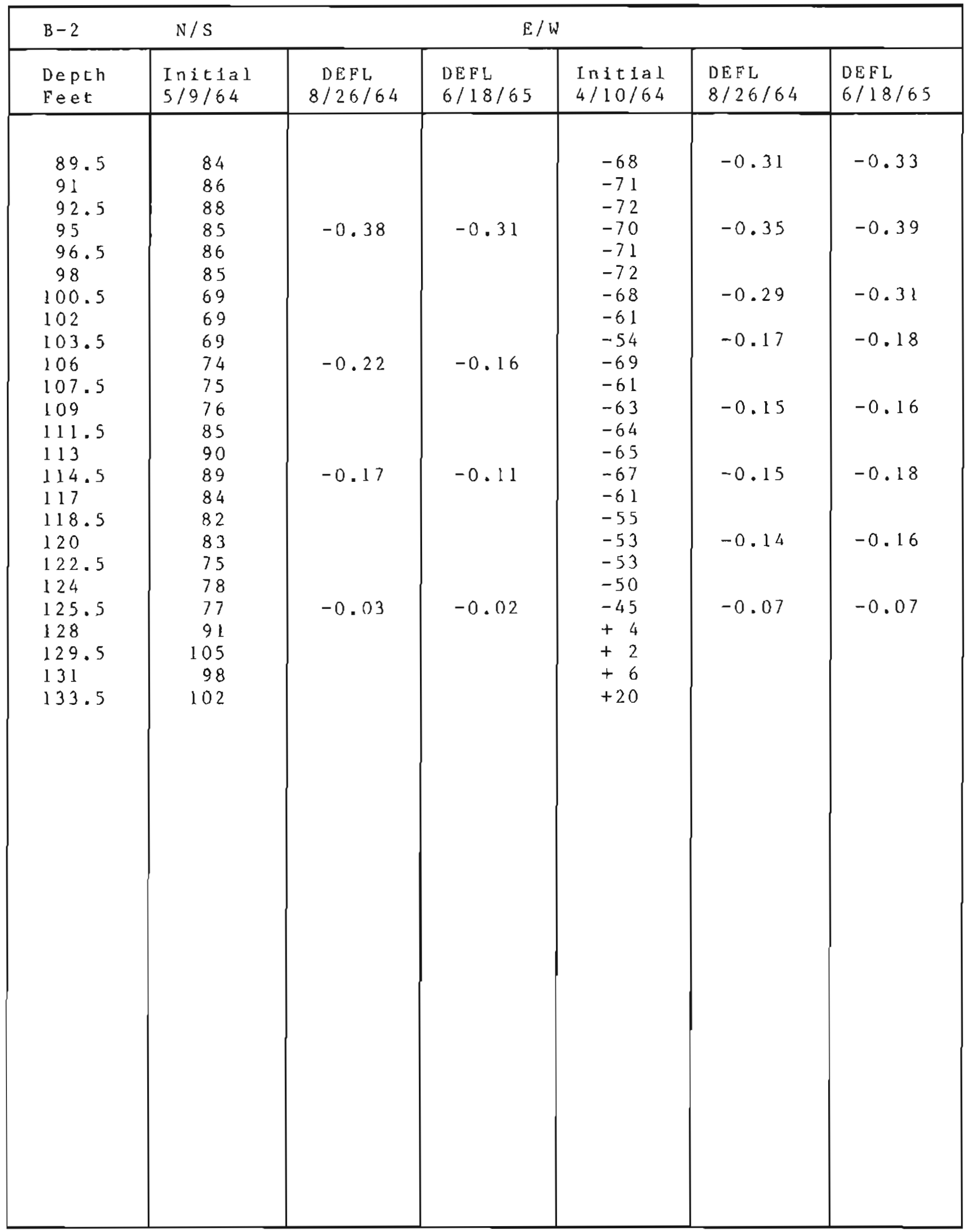




\begin{tabular}{|c|c|c|c|c|c|c|}
\hline$B-3$ & $\mathrm{~N} / \mathrm{S}$ & & & $E / W$ & & \\
\hline $\begin{array}{l}\text { Depth } \\
\text { Feet }\end{array}$ & $\begin{array}{l}\text { Initial } \\
5 / 2 / 64\end{array}$ & $\begin{array}{c}\text { DEFL } \\
8 / 26 / 64\end{array}$ & $\begin{array}{l}\text { DEFL } \\
6 / 14 / 65\end{array}$ & $\begin{array}{l}\text { Initial } \\
4 / 09 / 64\end{array}$ & $\begin{array}{l}\text { DEF L } \\
8 / 26 / 64\end{array}$ & $\begin{array}{l}\text { DEFL } \\
6 / 14 / 65\end{array}$ \\
\hline 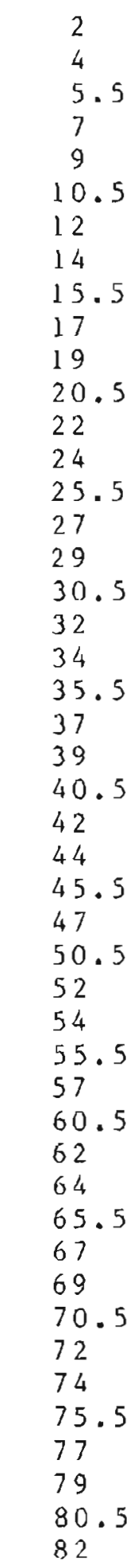 & $\begin{array}{l}135 \\
146 \\
147 \\
148 \\
187 \\
188 \\
190 \\
201 \\
202 \\
201 \\
199 \\
199 \\
200 \\
201 \\
200 \\
200 \\
202 \\
204 \\
203 \\
199 \\
198 \\
198 \\
190 \\
185 \\
184 \\
190 \\
193 \\
191 \\
186 \\
184 \\
167 \\
172 \\
169 \\
177 \\
176 \\
176 \\
173 \\
170 \\
162 \\
164 \\
167 \\
160 \\
159 \\
159 \\
152\end{array}$ & 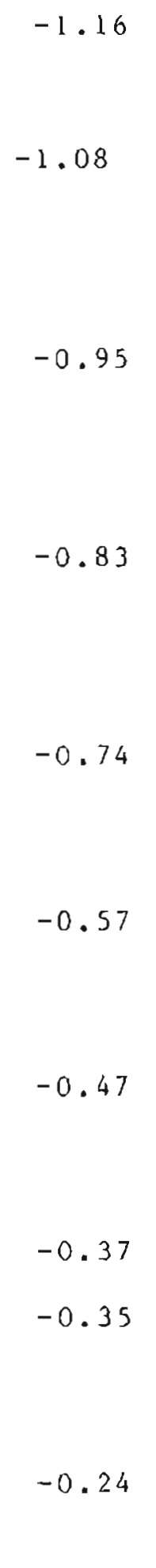 & $\begin{array}{l}-0.96 \\
-0.89 \\
-0.81 \\
-0.39 \\
-0.44 \\
-0.53 \\
-0.37 \\
-0.33 \\
-0.30\end{array}$ & 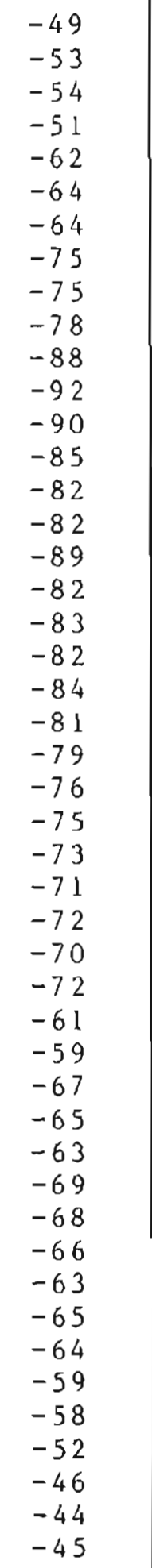 & $\begin{array}{l}-1.73 \\
-1.67 \\
-1.56 \\
-1.36 \\
-1.12 \\
-1.29 \\
-0.93 \\
-0.73 \\
-07\end{array}$ & $\begin{array}{l}-1.57 \\
-1.35 \\
-1.12\end{array}$ \\
\hline
\end{tabular}


76

INCLINOMETER STRAIN ANALYSES OF ANCHORAGE LANDSLIDES, 1965.80

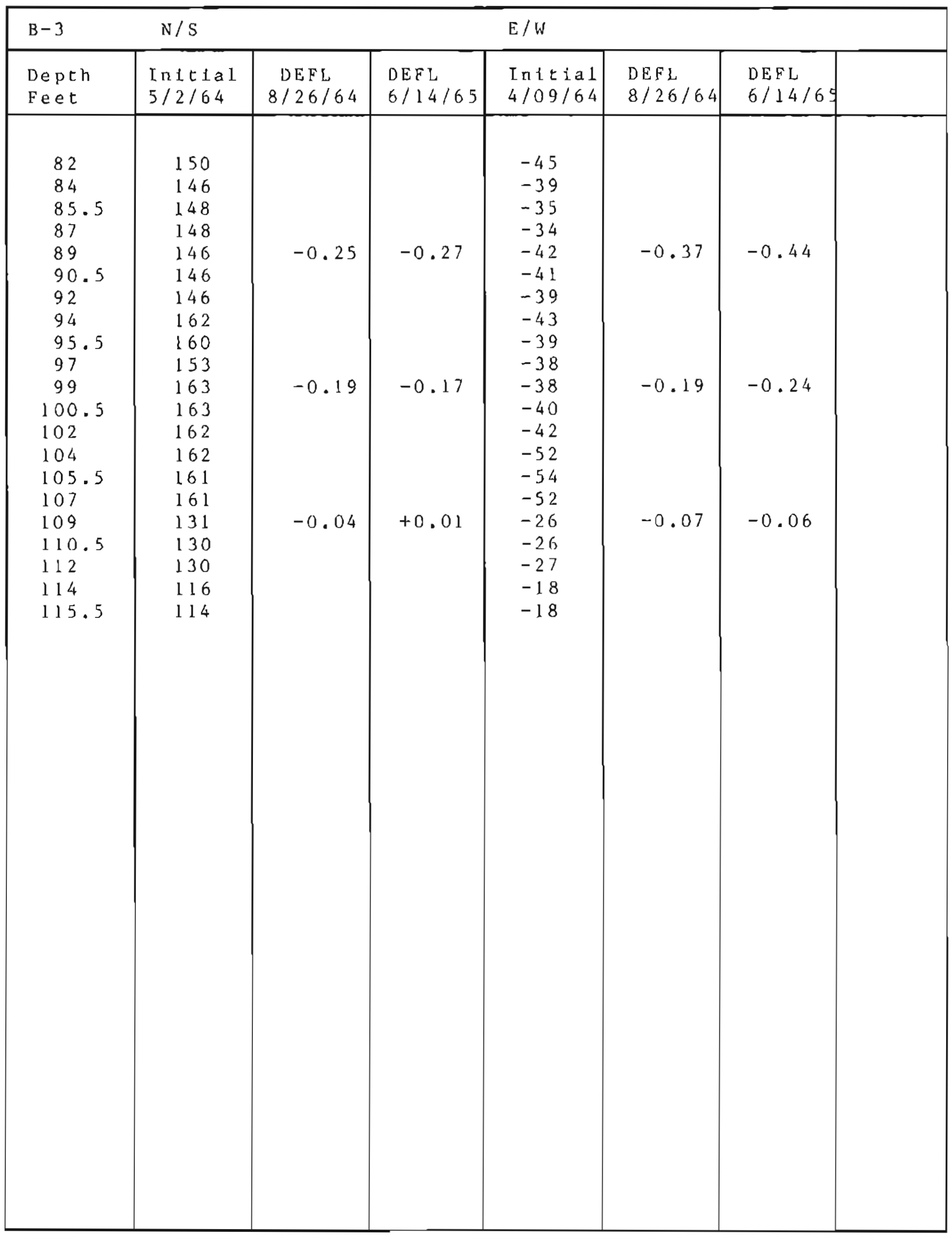




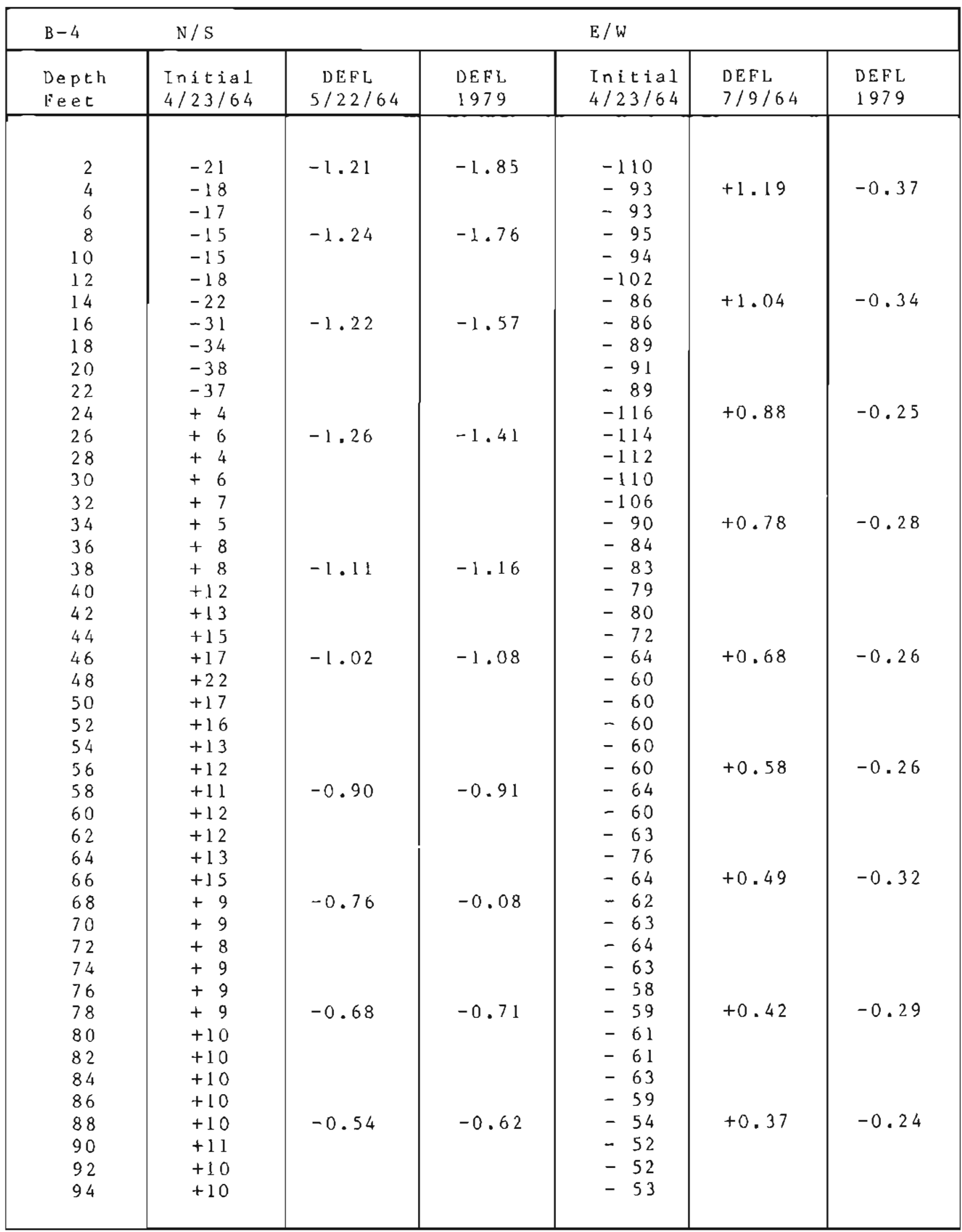




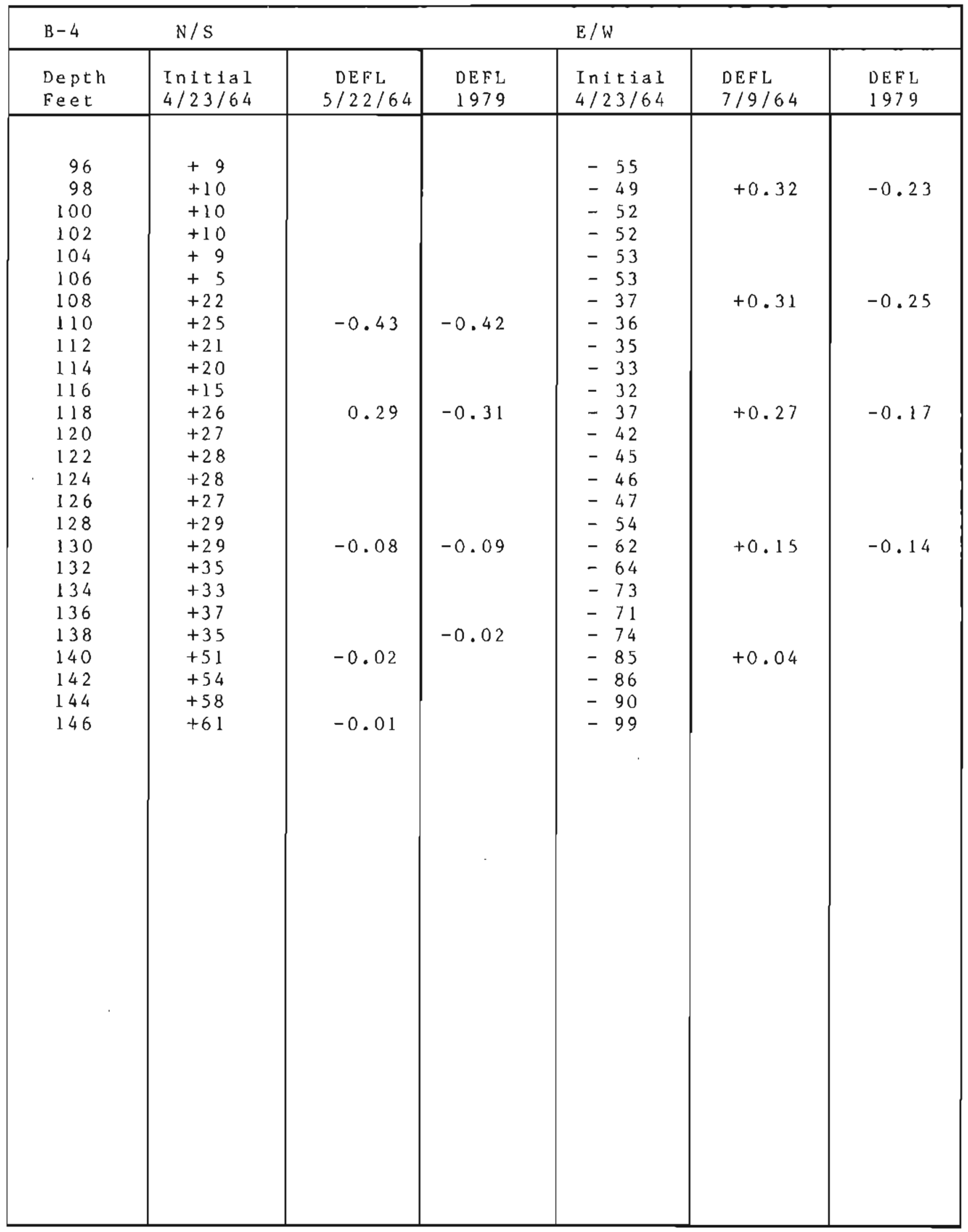




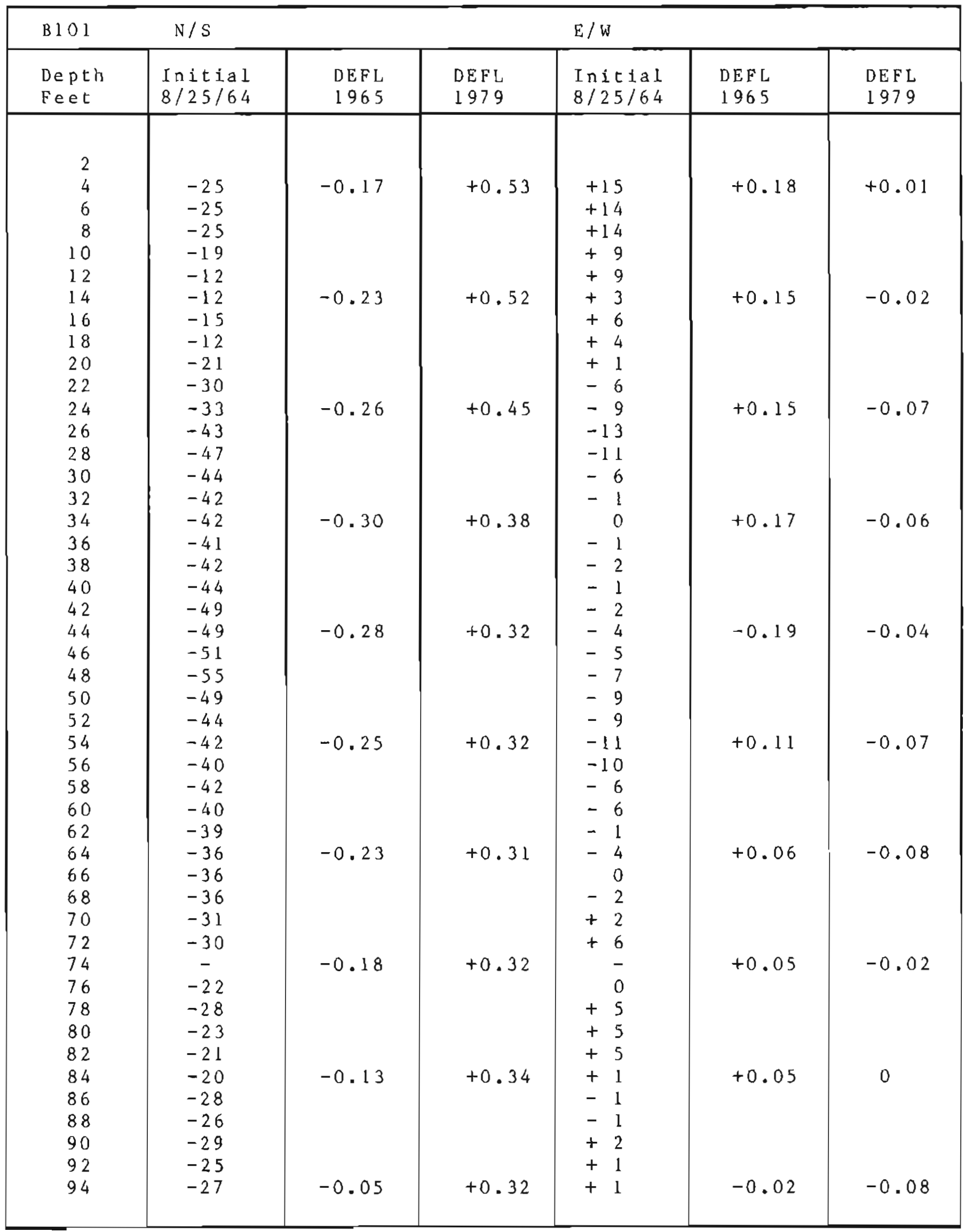




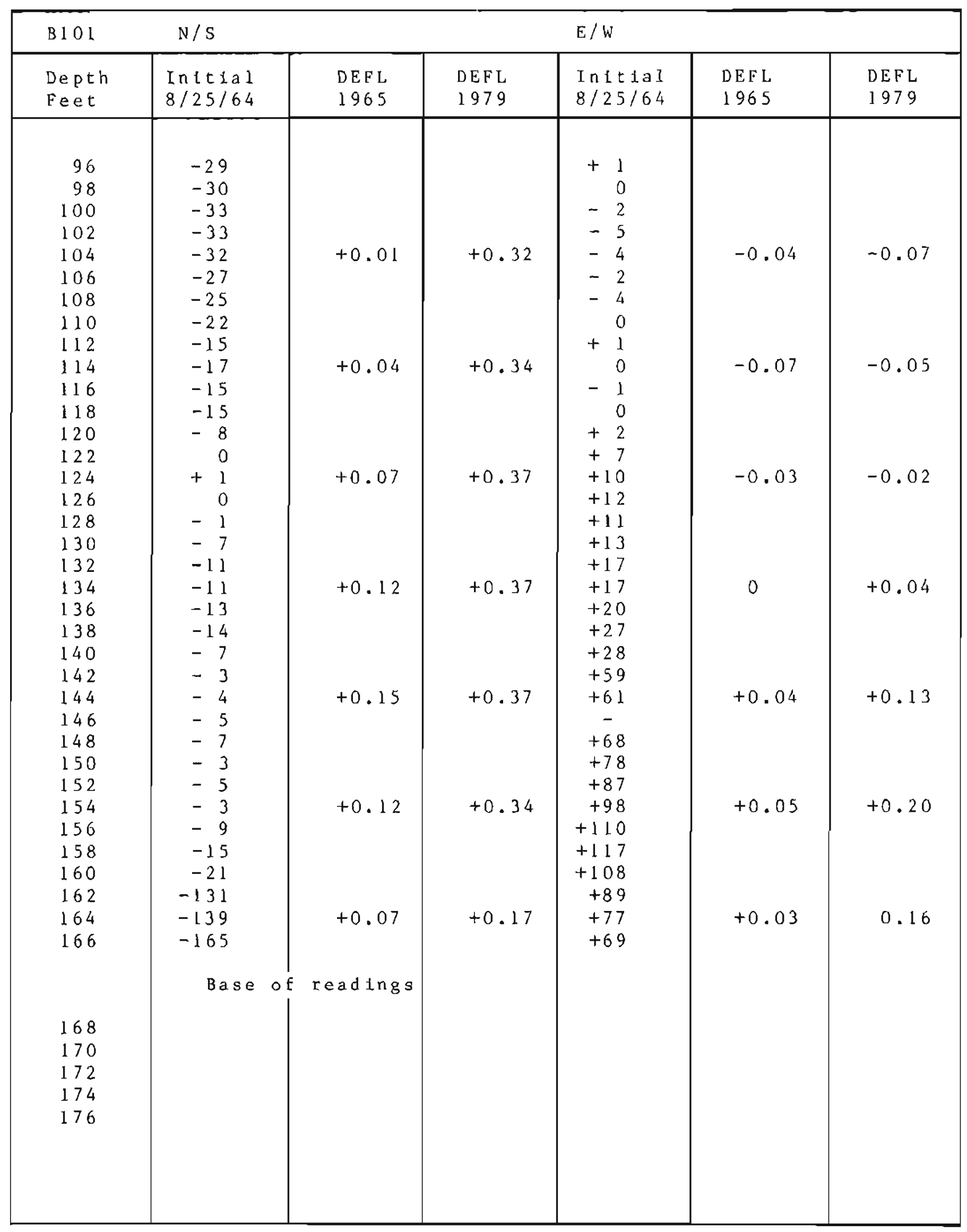




\begin{tabular}{|c|c|c|c|c|c|c|}
\hline$B \perp \perp 3$ & $N / S$ & & & $E / W$ & & \\
\hline $\begin{array}{l}\text { Depth } \\
\text { Feet }\end{array}$ & $\begin{array}{l}\text { Initia } 1 \\
7 / 3 / 64\end{array}$ & $\begin{array}{c}\text { DEFL } \\
8 / 25 / 64\end{array}$ & $\begin{array}{c}\text { DEFL } \\
6 / 11 / 65\end{array}$ & $\begin{array}{l}\text { Initial } \\
7 / 3 / 64\end{array}$ & $\begin{array}{c}\text { DEFL } \\
8 / 25 / 64\end{array}$ & $\begin{array}{c}\text { DEFL } \\
6 / 11 / 65\end{array}$ \\
\hline 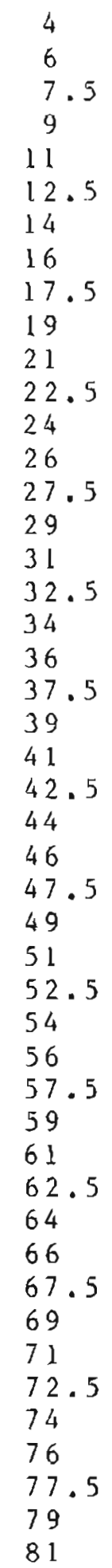 & 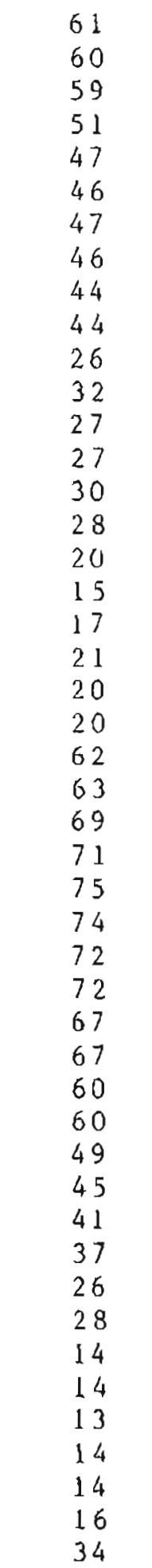 & 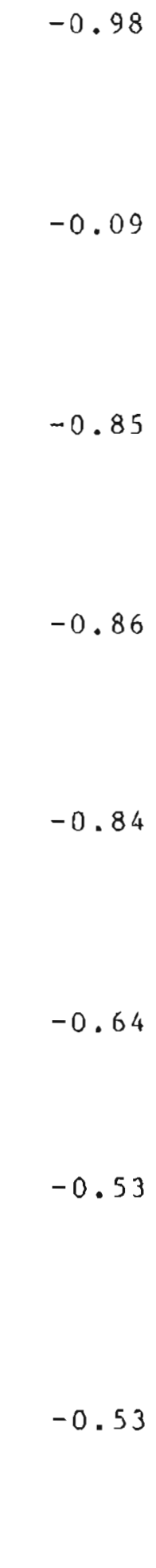 & $\begin{array}{l}-0.89 \\
-0.83 \\
-0.75 \\
-0.43 \\
-0.79 \\
-0.74\end{array}$ & 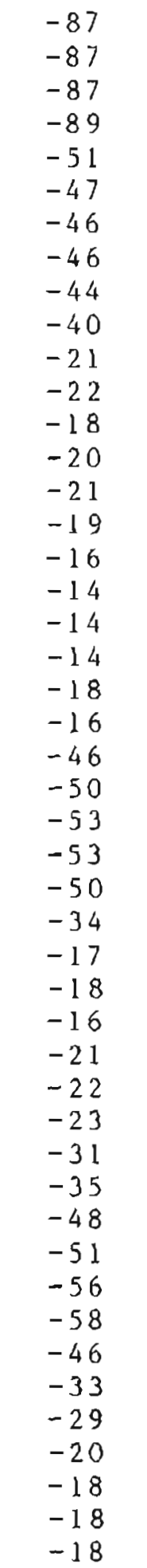 & $\begin{array}{l}+0.65 \\
+0.56 \\
+0.47 \\
+0.45 \\
+0.49 \\
+0.45 \\
+44\end{array}$ & $\begin{array}{l}+0.25 \\
+0.27\end{array}$ \\
\hline
\end{tabular}




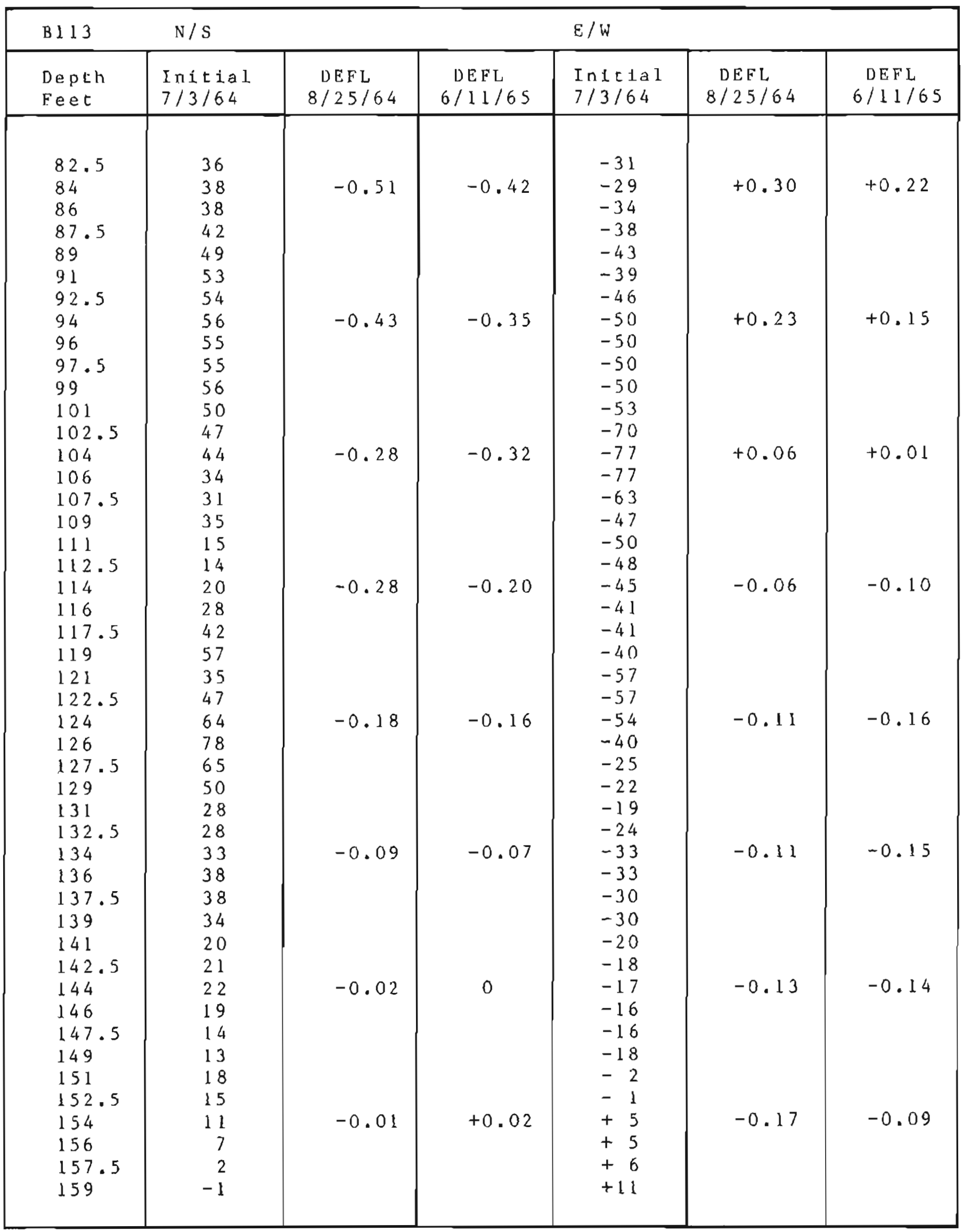


PROFESSIONAL REPORT 80

83

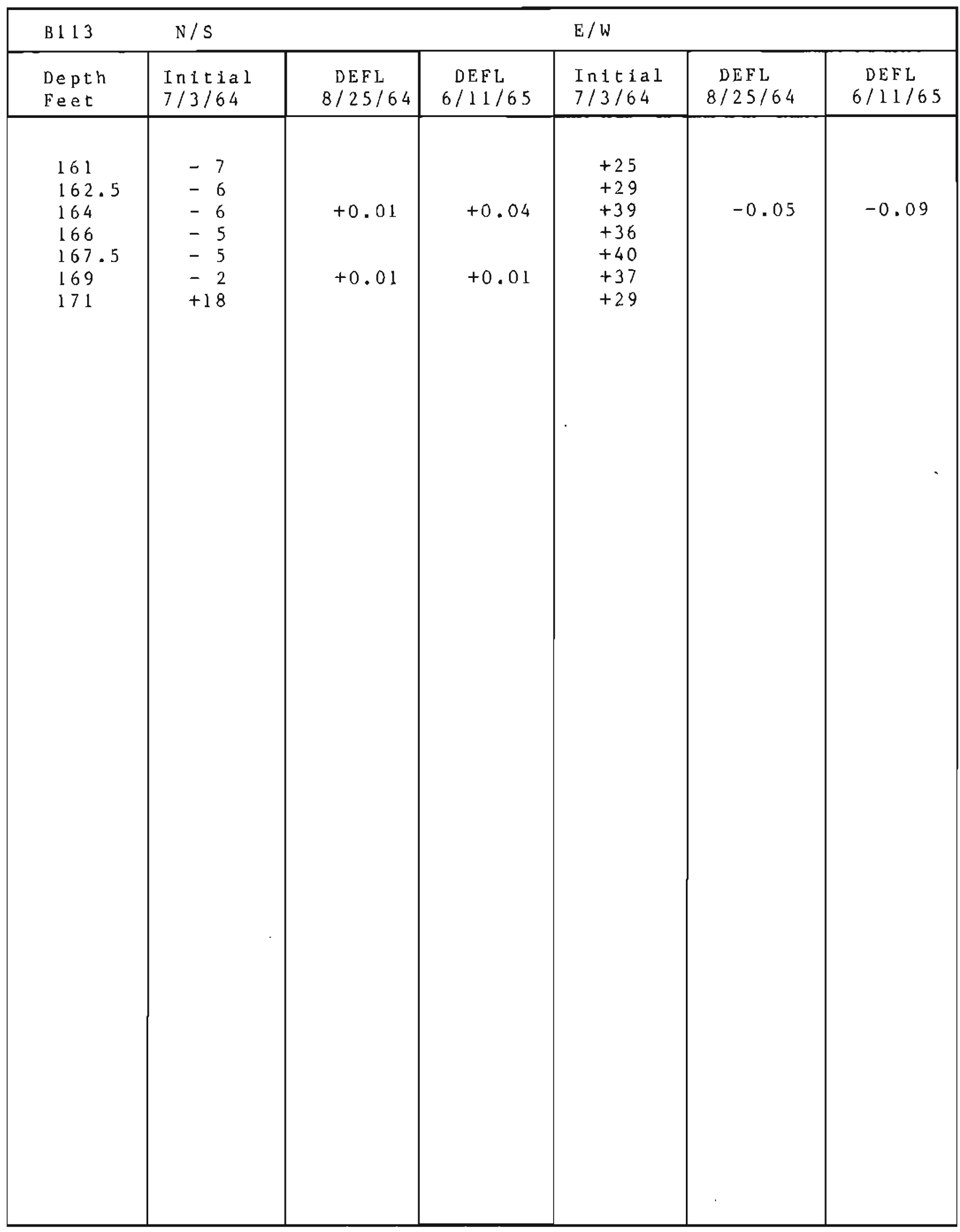




\begin{tabular}{|c|c|c|c|c|}
\hline $\mathrm{ClB}$ & $\mathrm{N} / \mathrm{S}$ & & $E / W$ & \\
\hline $\begin{array}{l}\text { Depth } \\
\text { Feet }\end{array}$ & $\begin{array}{l}\text { In } 1 \text { tial } \\
4 / 14 / 64\end{array}$ & $\begin{array}{c}\text { DEFL } \\
7 / 24 / 64\end{array}$ & $\begin{array}{l}\text { Initial } \\
4 / 11 / 64\end{array}$ & $\begin{array}{c}\text { DEFL } \\
5 / 26 / 64\end{array}$ \\
\hline $\begin{array}{l}1.5 \\
3 \\
4.5 \\
7 \\
8.5 \\
10 \\
12.5 \\
14 \\
15.5 \\
18 \\
19.5 \\
21 \\
23.5 \\
25 \\
26 \\
29 \\
30.5 \\
32 \\
34.5 \\
36 \\
37.5 \\
40 \\
41.5 \\
43 \\
45.5 \\
47 \\
48.5 \\
51 \\
52.5 \\
54 \\
56.5 \\
58 \\
59.5 \\
62 \\
63.5 \\
65 \\
66.5 \\
68 \\
70.5 \\
73 \\
74.5 \\
76 \\
78.5 \\
80 \\
81.5 \\
84 \\
85.5\end{array}$ & $\begin{array}{l}-70 \\
-68 \\
-65 \\
-59 \\
-60 \\
-58 \\
-56 \\
-53 \\
-47 \\
-41 \\
-41 \\
-43 \\
-52 \\
-51 \\
-49 \\
-34 \\
-36 \\
-36 \\
-36 \\
-34 \\
-37 \\
-29 \\
-31 \\
-31 \\
-49 \\
-49 \\
-48 \\
-24 \\
-21 \\
-21 \\
-15 \\
-14 \\
-14 \\
-20 \\
-21 \\
-25 \\
-33 \\
-43 \\
-39 \\
-33 \\
-32 \\
-33 \\
-32 \\
-34 \\
-36 \\
-42 \\
-40\end{array}$ & $\begin{array}{l}+0.28 \\
+0.22 \\
+0.13 \\
+0.12 \\
+0.44 \\
+0.45 \\
+0.39 \\
+0.12 \\
+0.18 \\
+0.23 \\
+0.27 \\
+0.28\end{array}$ & 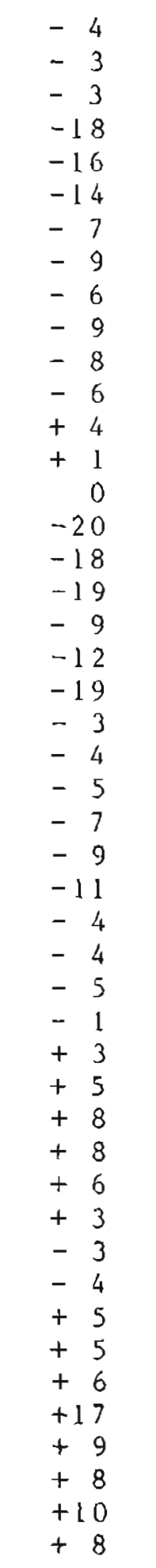 & 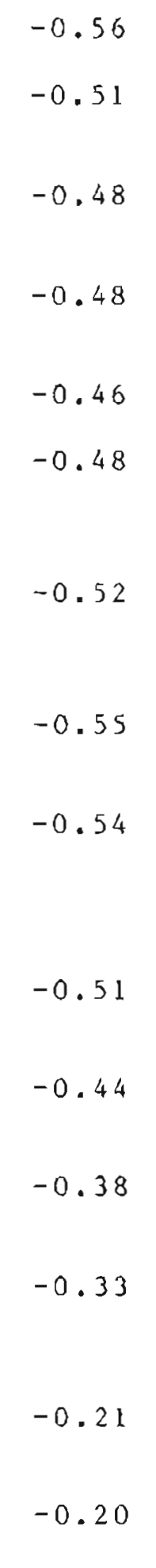 \\
\hline
\end{tabular}




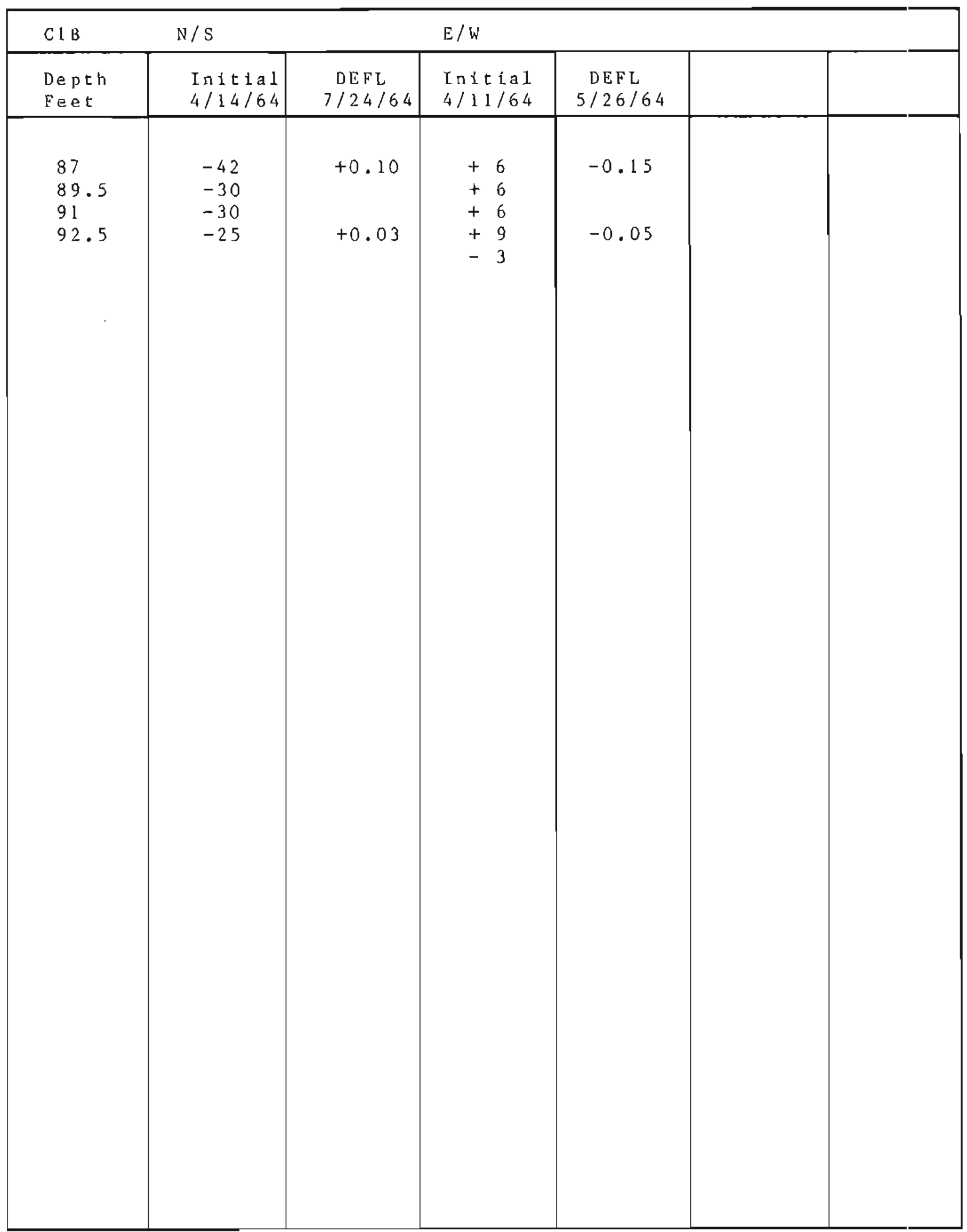




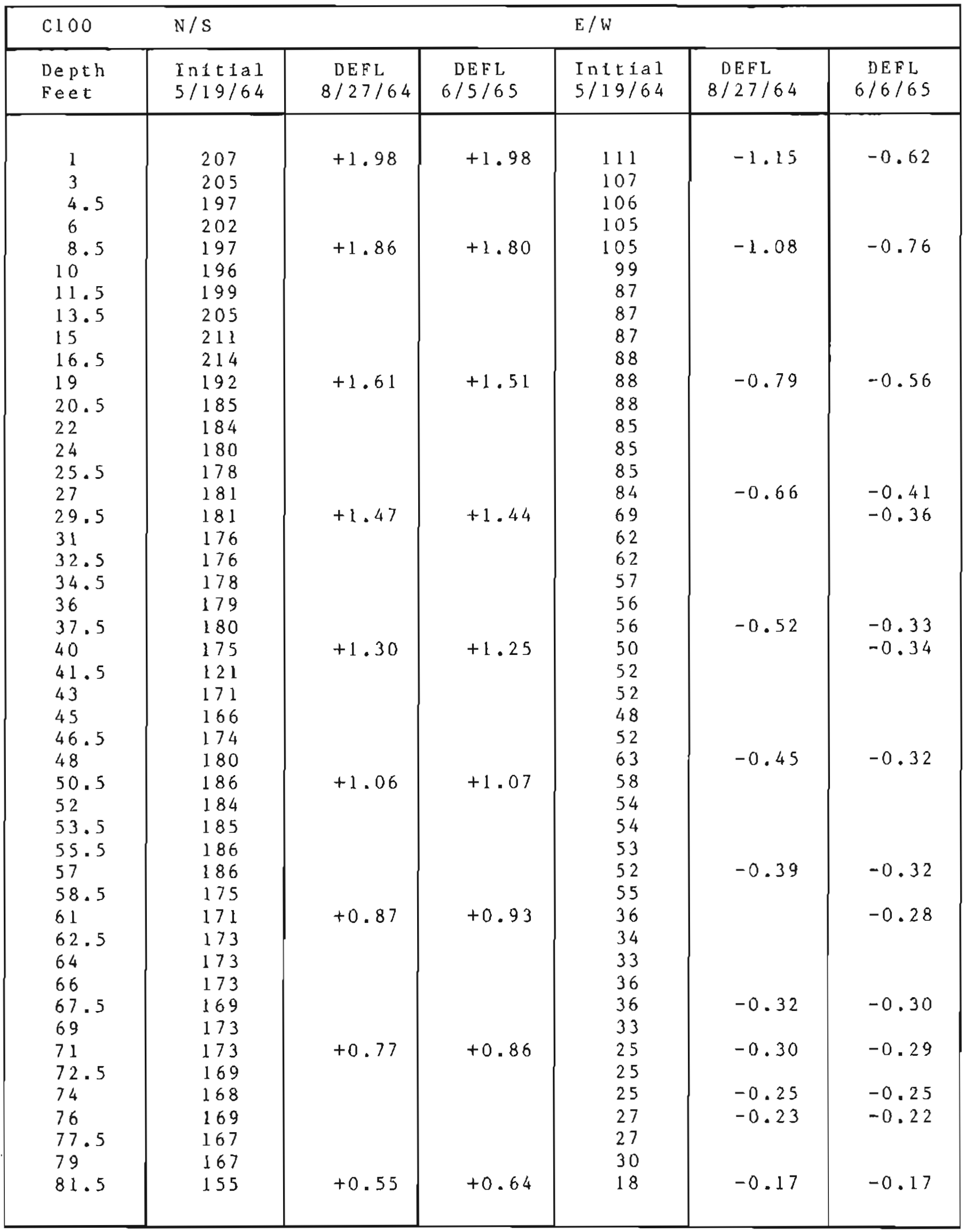




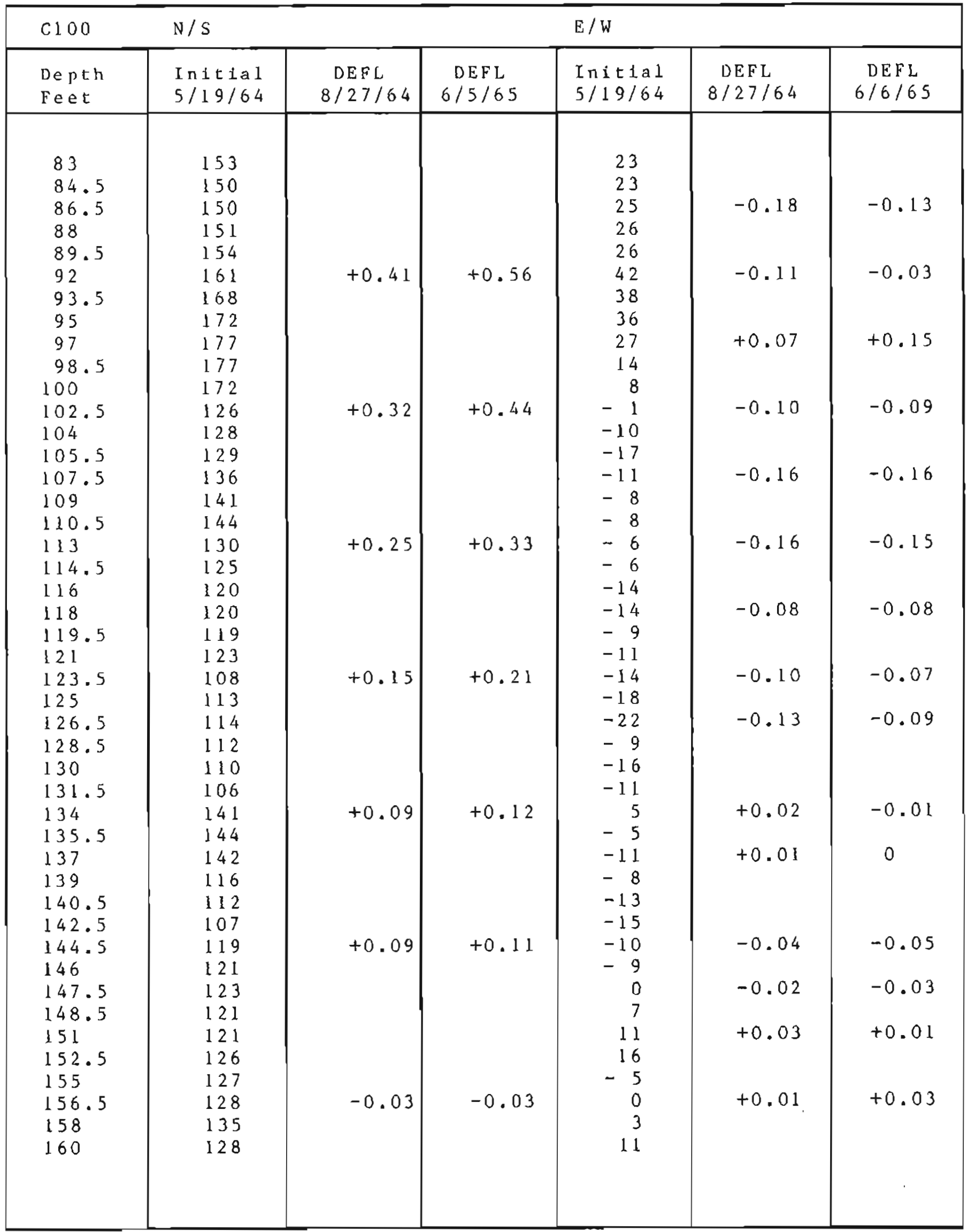




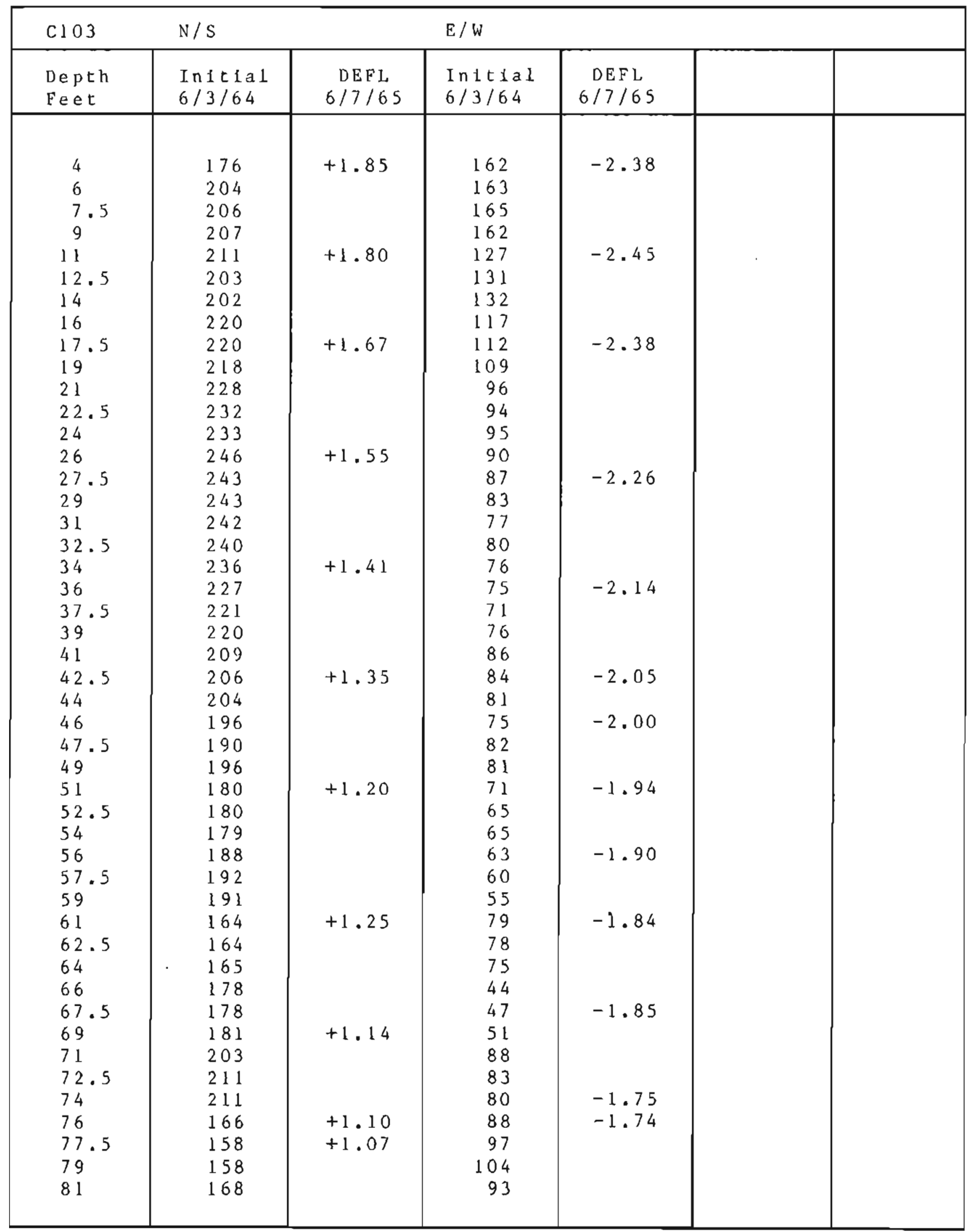




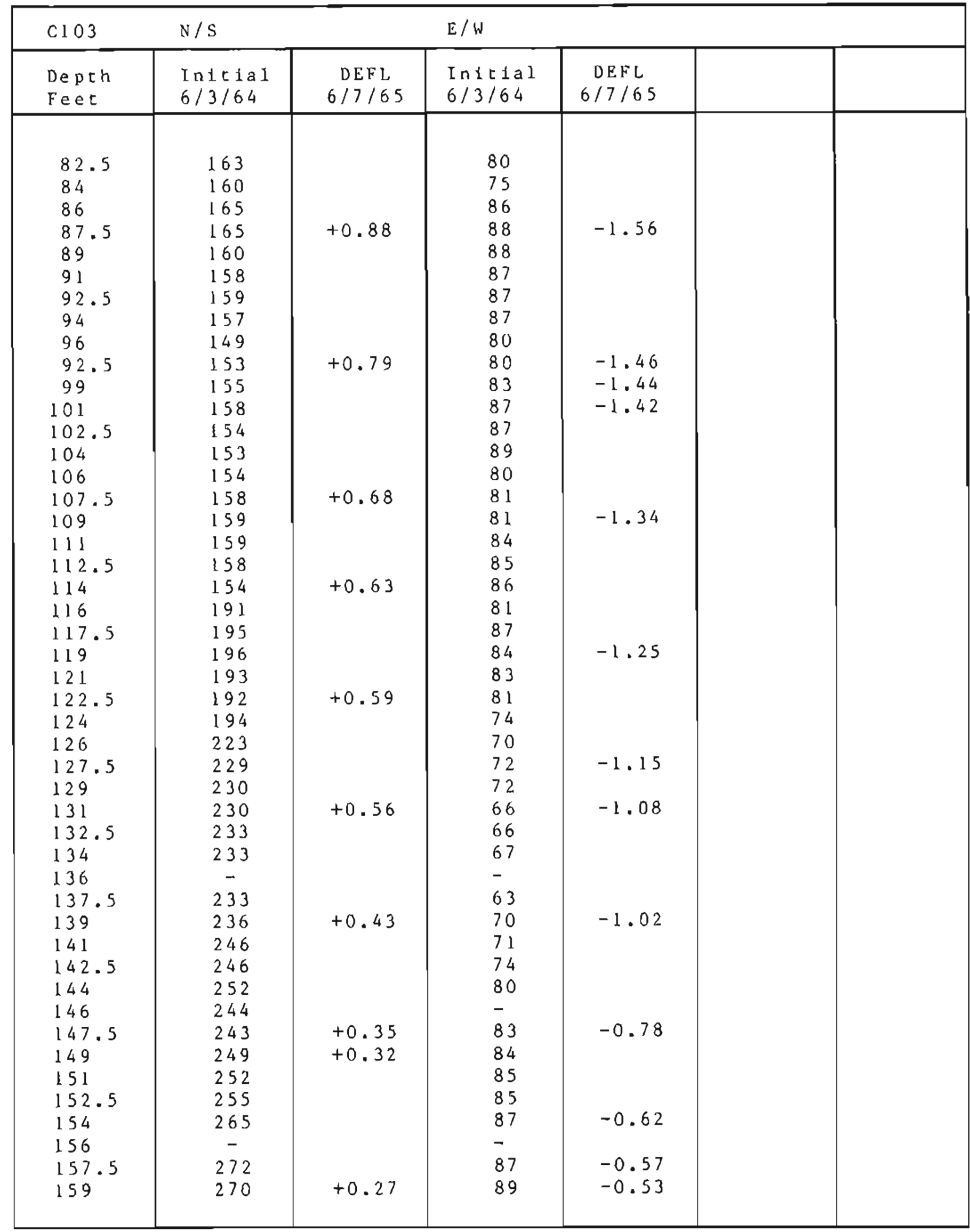




\begin{tabular}{|c|c|c|c|c|}
\hline$C 103$ & $N / S$ & & $E / W$ & \\
\hline $\begin{array}{l}\text { Depth } \\
\text { Feet }\end{array}$ & $\begin{array}{l}\text { Inftial } \\
6 / 3 / 64\end{array}$ & $\begin{array}{c}\text { DEFL } \\
6 / 7 / 65\end{array}$ & $\begin{array}{l}\text { Inttial } \\
6 / 3 / 64\end{array}$ & $\begin{array}{c}\text { DEFL } \\
6 / 7 / 65\end{array}$ \\
\hline $\begin{array}{l}161.5 \\
162.5 \\
164 \\
166 \\
167.5 \\
169 \\
171 \\
172.5 \\
174 \\
176 \\
177.5 \\
179 \\
181\end{array}$ & $\begin{array}{l}269 \\
270 \\
270 \\
270 \\
- \\
272 \\
281 \\
269 \\
254 \\
283 \\
288 \\
289 \\
300\end{array}$ & $\begin{array}{l}+0.08 \\
-0.06\end{array}$ & $\begin{array}{l}91 \\
97 \\
97 \\
90 \\
- \\
90 \\
83 \\
85 \\
84 \\
84 \\
- \\
106 \\
106\end{array}$ & $\begin{array}{l}-0.39 \\
-0.34 \\
-0.21\end{array}$ \\
\hline
\end{tabular}




\begin{tabular}{|c|c|c|c|c|c|c|}
\hline C109 & $N / S$ & & & $\mathrm{E} / \mathrm{W}$ & & \\
\hline $\begin{array}{l}\text { Depth } \\
\text { Feet }\end{array}$ & $\begin{array}{l}\text { Jn1 t ial } \\
7 / 18 / 64\end{array}$ & $\begin{array}{c}\text { DEFL } \\
8 / 27 / 64\end{array}$ & $\begin{array}{c}\text { DEFL } \\
6 / 4 / 65\end{array}$ & $\begin{array}{l}\operatorname{In} 1 \mathrm{t} 1 \mathrm{a} 1 \\
7 / 14 / 64\end{array}$ & $\begin{array}{c}\text { DEE L } \\
8 / 27 / 64\end{array}$ & $\begin{array}{c}\text { DEFL } \\
6 / 4 / 65\end{array}$ \\
\hline 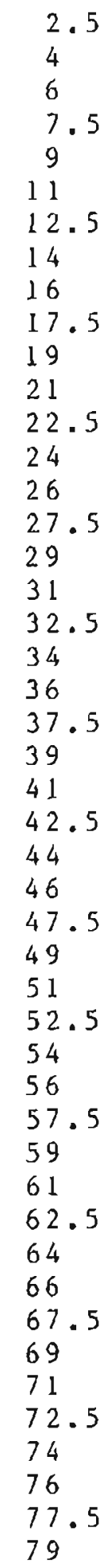 & 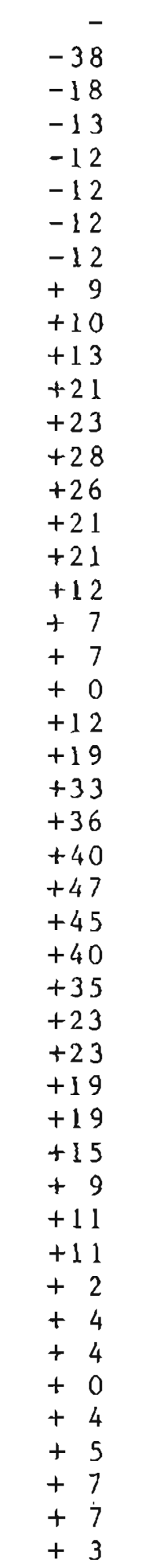 & $\begin{array}{l}+0.50 \\
+0.48 \\
+0.44 \\
+0.06 \\
+0.04 \\
+0.41 \\
+0.19 \\
+0.27 \\
+0 \\
+0.46\end{array}$ & $\begin{array}{l}+1.30 \\
+1.08 \\
+0.99 \\
+0.46 \\
+0.44 \\
+1.03 \\
+0.75 \\
+0.87 \\
+0.61 \\
+0.96\end{array}$ & 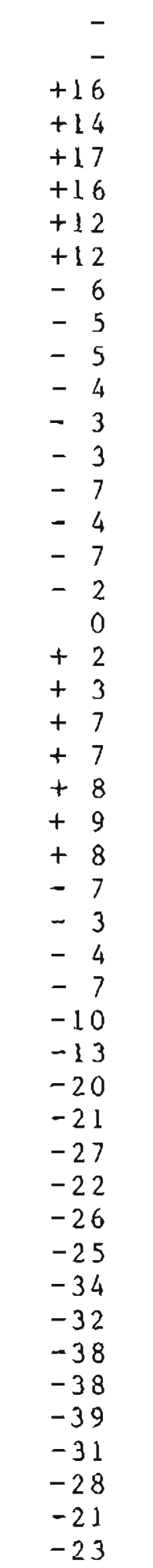 & $\begin{array}{l}-0.31 \\
-0.32 \\
-0.36 \\
-0.38 \\
-0.33\end{array}$ & $\begin{array}{l}+0.05 \\
+0.01\end{array}$ \\
\hline
\end{tabular}




\begin{tabular}{|c|c|c|c|c|c|c|}
\hline C109 & $N / S$ & & & $E / W$ & & \\
\hline $\begin{array}{l}\text { Depth } \\
\text { Feet }\end{array}$ & $\begin{array}{l}\text { Inttial } \\
7 / 18 / 64\end{array}$ & $\begin{array}{c}\text { DEFL } \\
8 / 27 / 64\end{array}$ & $\begin{array}{c}\text { DEFL } \\
6 / 4 / 65\end{array}$ & $\begin{array}{l}\text { Initial } \\
7 / 14 / 64\end{array}$ & $\begin{array}{c}\text { DEFL } \\
8 / 27 / 64\end{array}$ & $\begin{array}{c}\text { DEF L } \\
6 / 4 / 65\end{array}$ \\
\hline 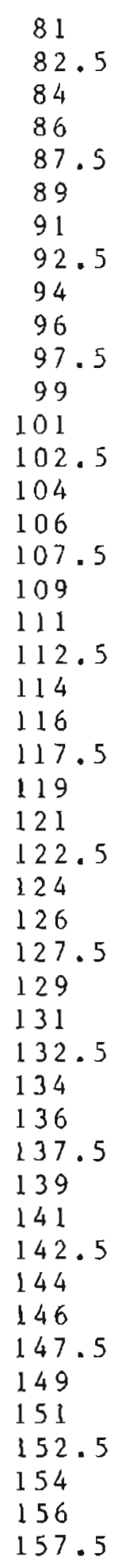 & 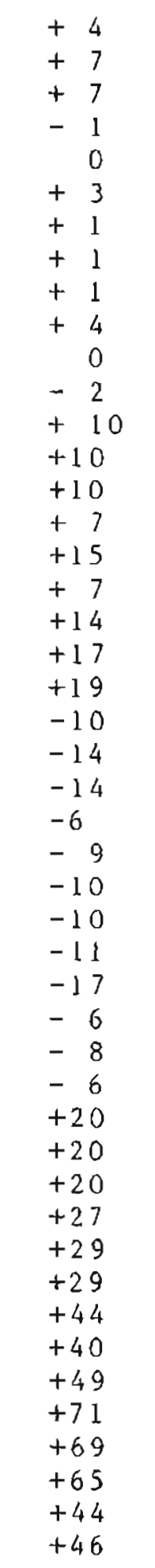 & $\begin{array}{l}-0.02 \\
-0.01 \\
-0.01 \\
-0.08 \\
-0.03 \\
-0.04 \\
-0.06\end{array}$ & $\begin{array}{l}+0.39 \\
+0.34 \\
+0.33 \\
+0.22 \\
+0.06 \\
+0.10 \\
+0.19\end{array}$ & $\begin{array}{l}-18 \\
-17 \\
-17 \\
-13 \\
-14 \\
-17 \\
-9 \\
-\quad 6 \\
-6 \\
-30 \\
-28 \\
-28 \\
-25 \\
-26 \\
-28 \\
-11 \\
-20 \\
-27 \\
0 \\
0 \\
-0 \\
-9 \\
-9 \\
-19 \\
-17 \\
-19 \\
-23 \\
-17 \\
-18 \\
-20 \\
-23 \\
-20 \\
-22 \\
-12 \\
-10 \\
-11 \\
+16 \\
+20 \\
+25 \\
+47 \\
+52 \\
-52 \\
-82 \\
+81 \\
+79 \\
+79\end{array}$ & $\begin{array}{l}-0.12 \\
-0.11 \\
-0.11 \\
-0.10\end{array}$ & $\begin{array}{r} \\
+0.09\end{array}$ \\
\hline
\end{tabular}


PROFESSICINAL REPORT 80

\begin{tabular}{|c|c|c|c|c|c|c|}
\hline $\mathrm{ClO}$ & $\mathrm{N} / \mathrm{S}$ & & & $E / W$ & & \\
\hline $\begin{array}{l}\text { Depth } \\
\text { Feet }\end{array}$ & $\begin{array}{l}\text { Initial } \\
7 / 18 / 64\end{array}$ & $\begin{array}{c}\text { DEFL } \\
8 / 27 / 64\end{array}$ & $\begin{array}{c}\text { DEFL } \\
6 / 4 / 65\end{array}$ & $\begin{array}{l}\text { Initial } \\
7 / 14 / 64\end{array}$ & $\begin{array}{c}\text { DEFL } \\
8 / 27 / 64\end{array}$ & $\begin{array}{c}\text { DEFL } \\
6 / 4 / 65\end{array}$ \\
\hline $\begin{array}{l}159 \\
161 \\
162.5 \\
164 \\
166 \\
167.5 \\
169 \\
171 \\
172.5 \\
174 \\
176 \\
177.5 \\
179 \\
181 \\
182.5 \\
184\end{array}$ & $\begin{array}{l}+46 \\
-\quad 4 \\
-\quad 6 \\
-9 \\
-4 \\
-\quad 2 \\
-\quad 3 \\
-19 \\
-23 \\
-34 \\
-93 \\
-91 \\
-93 \\
-88 \\
-84 \\
-89\end{array}$ & $\begin{array}{l}-0.06 \\
-0.03\end{array}$ & $\begin{array}{l}+0.02 \\
-0.01\end{array}$ & $\begin{array}{l}+79 \\
+49 \\
+46 \\
+38 \\
-7 \\
-7 \\
-\quad 6 \\
-4 \\
-4 \\
-4 \\
+8 \\
+10 \\
+15 \\
+59 \\
+59 \\
+59\end{array}$ & $\begin{array}{l}-0.05 \\
-0.01\end{array}$ & $\begin{array}{c}0 \\
+0.01\end{array}$ \\
\hline
\end{tabular}




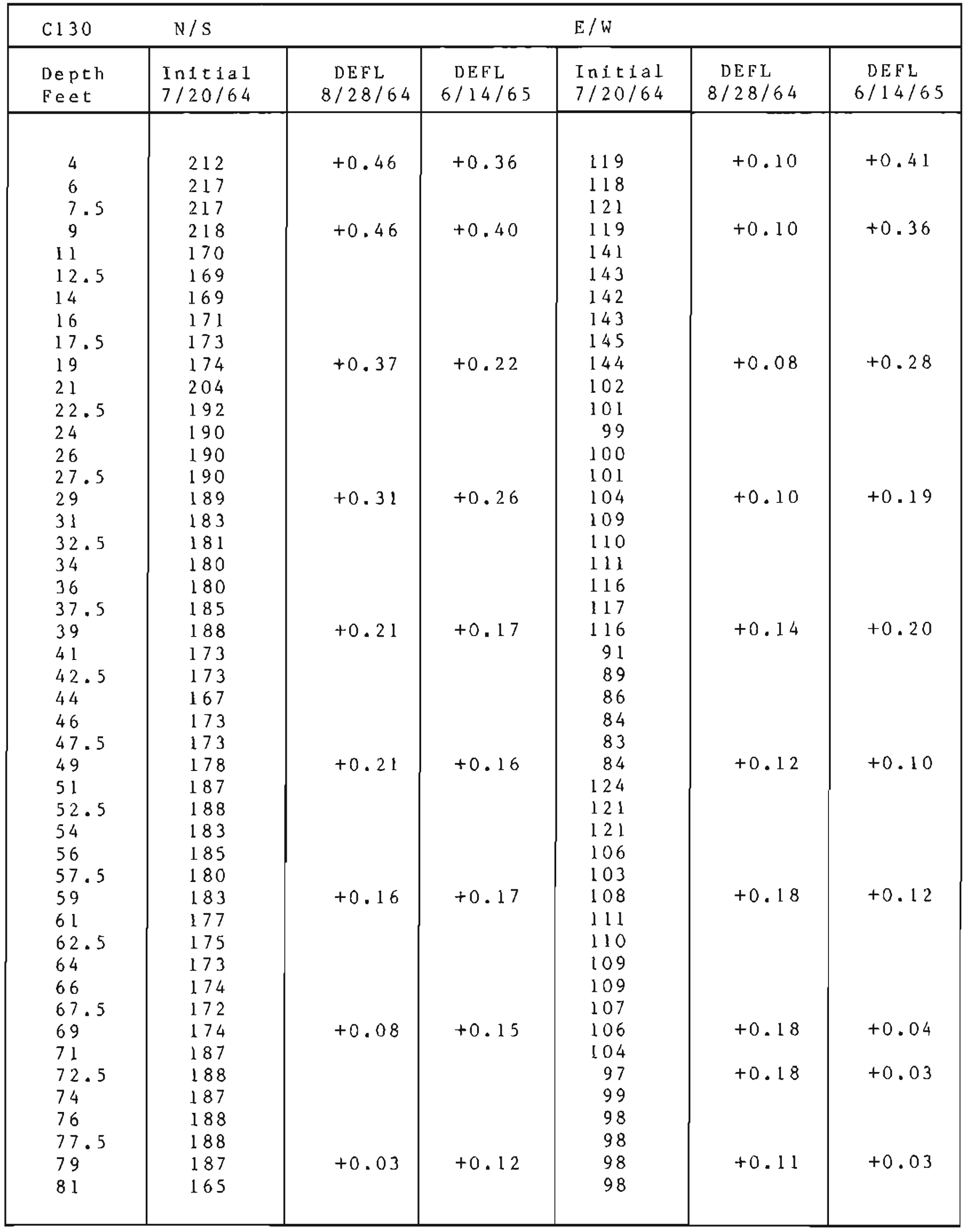


PROFESSIONAL REPORT 80

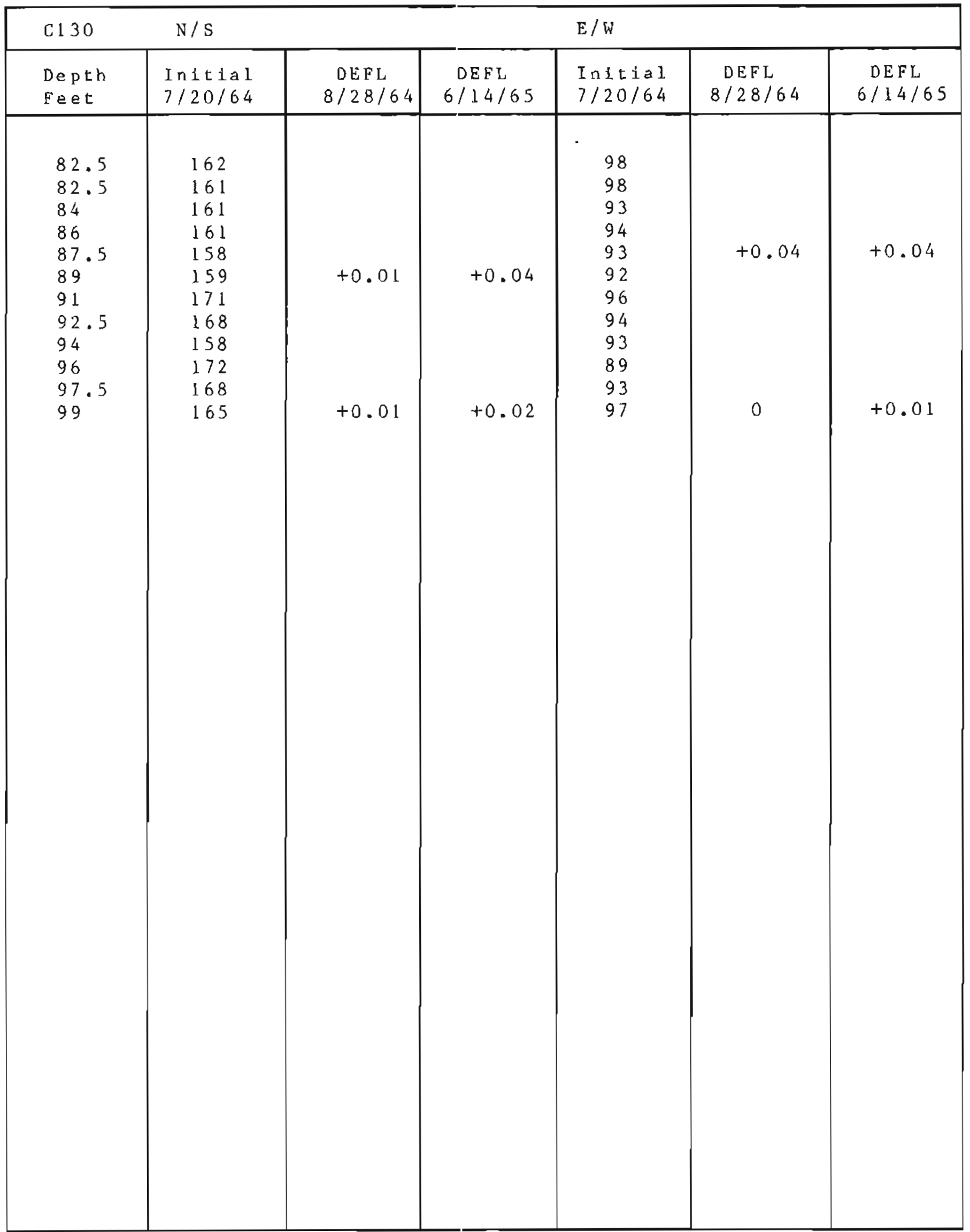




\begin{tabular}{|c|c|c|c|c|}
\hline C134 & $N / S$ & & & \\
\hline $\begin{array}{l}\text { Depth } \\
\text { Feet }\end{array}$ & $\begin{array}{l}\text { Initial } \\
7 / 10 / 64\end{array}$ & $\begin{array}{c}\text { DEFL } \\
8 / 28 / 64\end{array}$ & $\begin{array}{l}\text { DEFL } \\
6 / 14 / 65\end{array}$ & $\begin{array}{l}\text { DEFL } \\
1979\end{array}$ \\
\hline $\begin{array}{l}2 \\
4 \\
6 \\
8 \\
10 \\
12 \\
14 \\
16 \\
18 \\
20 \\
22 \\
24 \\
26 \\
28 \\
30 \\
32 \\
34 \\
36 \\
38 \\
40 \\
42 \\
44 \\
46 \\
48 \\
50 \\
52 \\
54 \\
56 \\
58 \\
60 \\
62 \\
64 \\
66 \\
68 \\
70 \\
72 \\
74 \\
76 \\
78 \\
80 \\
82 \\
84 \\
86 \\
88 \\
90 \\
92 \\
94\end{array}$ & $\begin{array}{r}+69 \\
+60 \\
+60 \\
+60 \\
+60 \\
+58 \\
+69 \\
+71 \\
+70 \\
+68 \\
+71 \\
+79 \\
+81 \\
+83 \\
+83 \\
+83 \\
+75 \\
+74 \\
+75 \\
+77 \\
+77 \\
+71 \\
+75 \\
+78 \\
+82 \\
+82 \\
+91 \\
+91 \\
+96 \\
+96 \\
+96 \\
+106 \\
+107 \\
+104 \\
+100 \\
+99 \\
+100 \\
+99 \\
+97 \\
+100 \\
+101 \\
+105 \\
+107 \\
+113 \\
+112 \\
+121\end{array}$ & $\begin{array}{l}+0.02 \\
-0.03 \\
-0.05 \\
0 \\
+0.02 \\
-0.03 \\
-0.04 \\
-0.08 \\
+0.05 \\
+0.03\end{array}$ & $\begin{array}{l}+0.80 \\
+0.66 \\
+0.50 \\
+0.55 \\
+0.56 \\
+0.46 \\
+0.22 \\
+0.43 \\
+0.43 \\
+0.04\end{array}$ & $\begin{array}{l}+0.08 \\
+0.02 \\
-0.14 \\
-0.11 \\
-0.07\end{array}$ \\
\hline
\end{tabular}


PROFESSIONAL REPORT 80

97

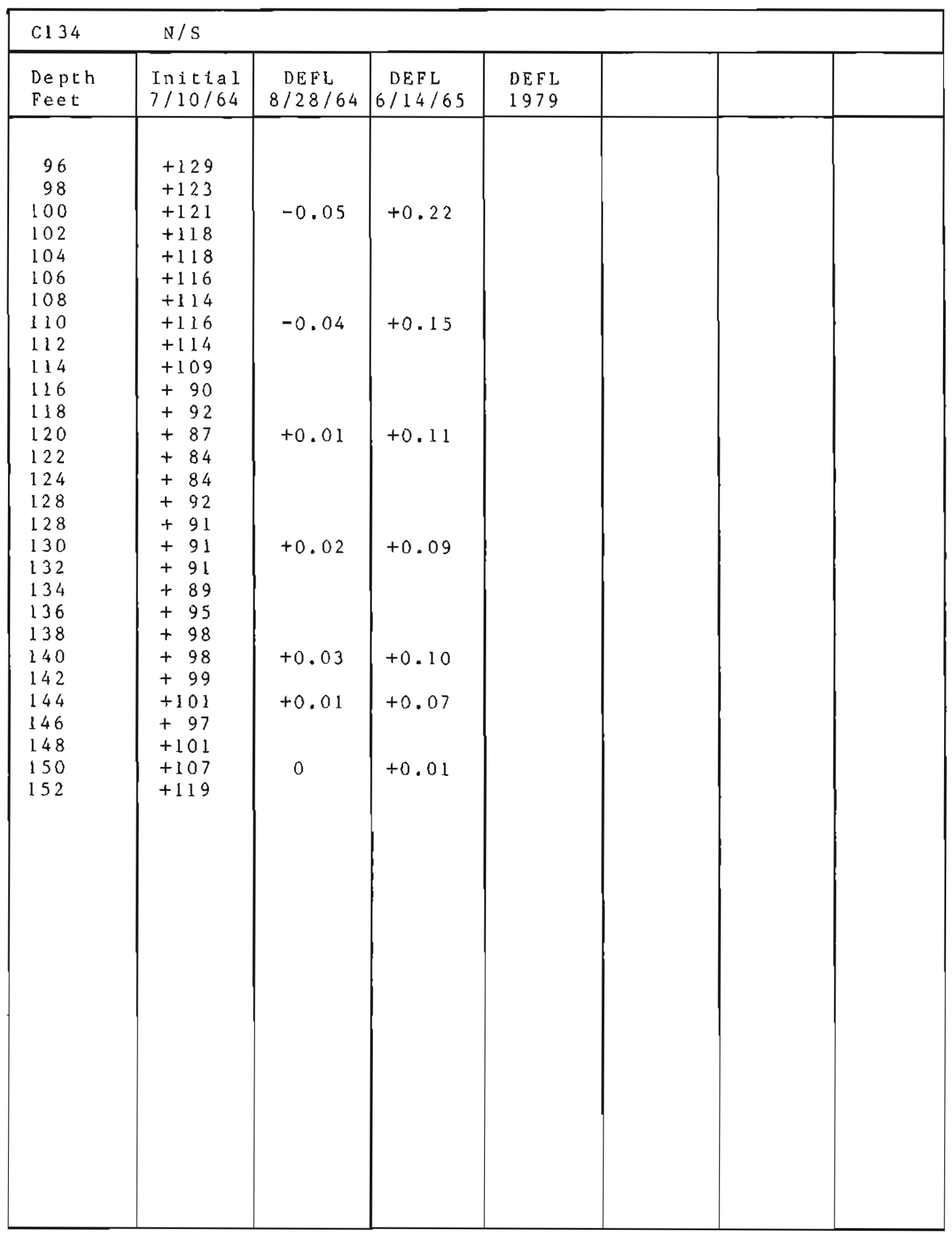




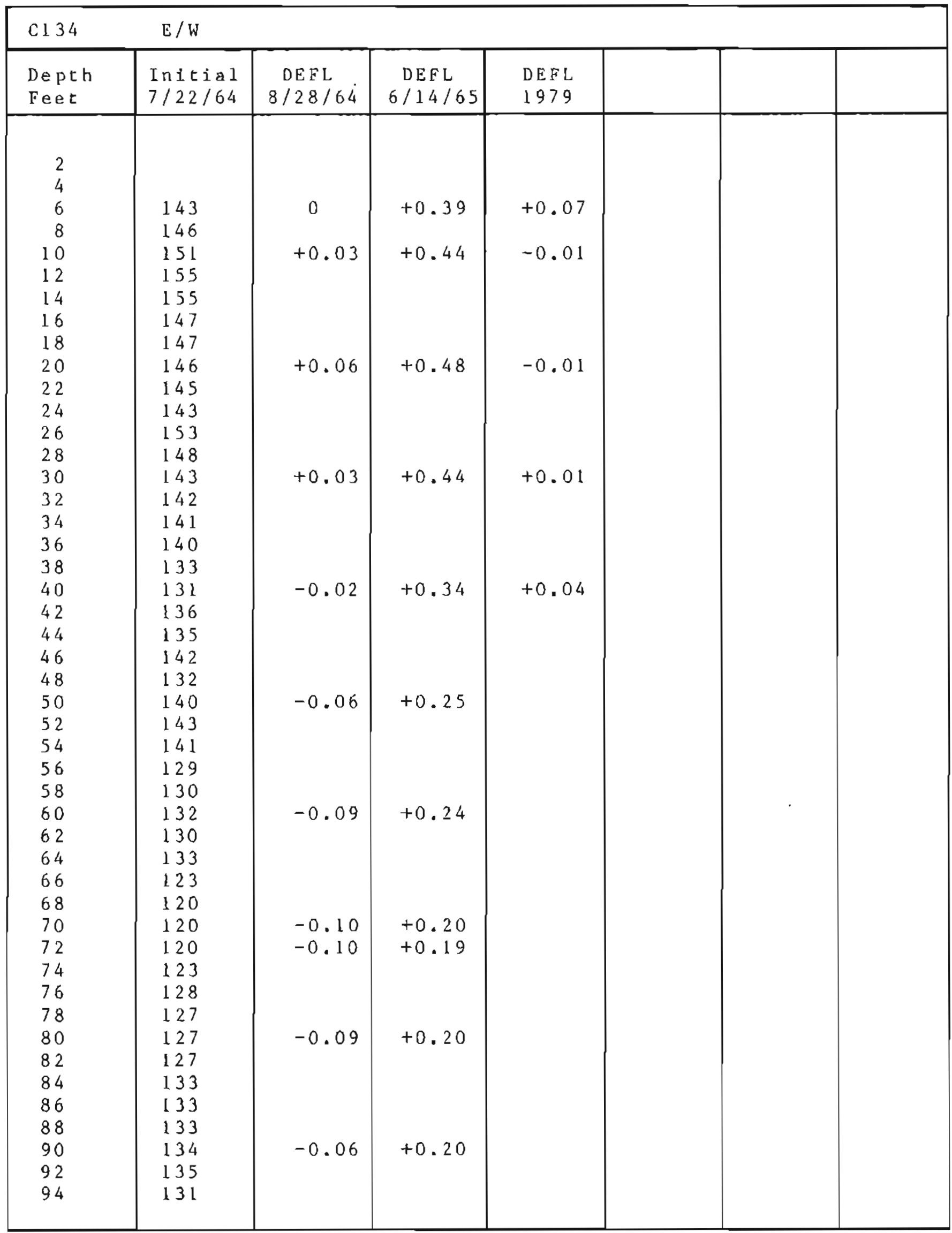




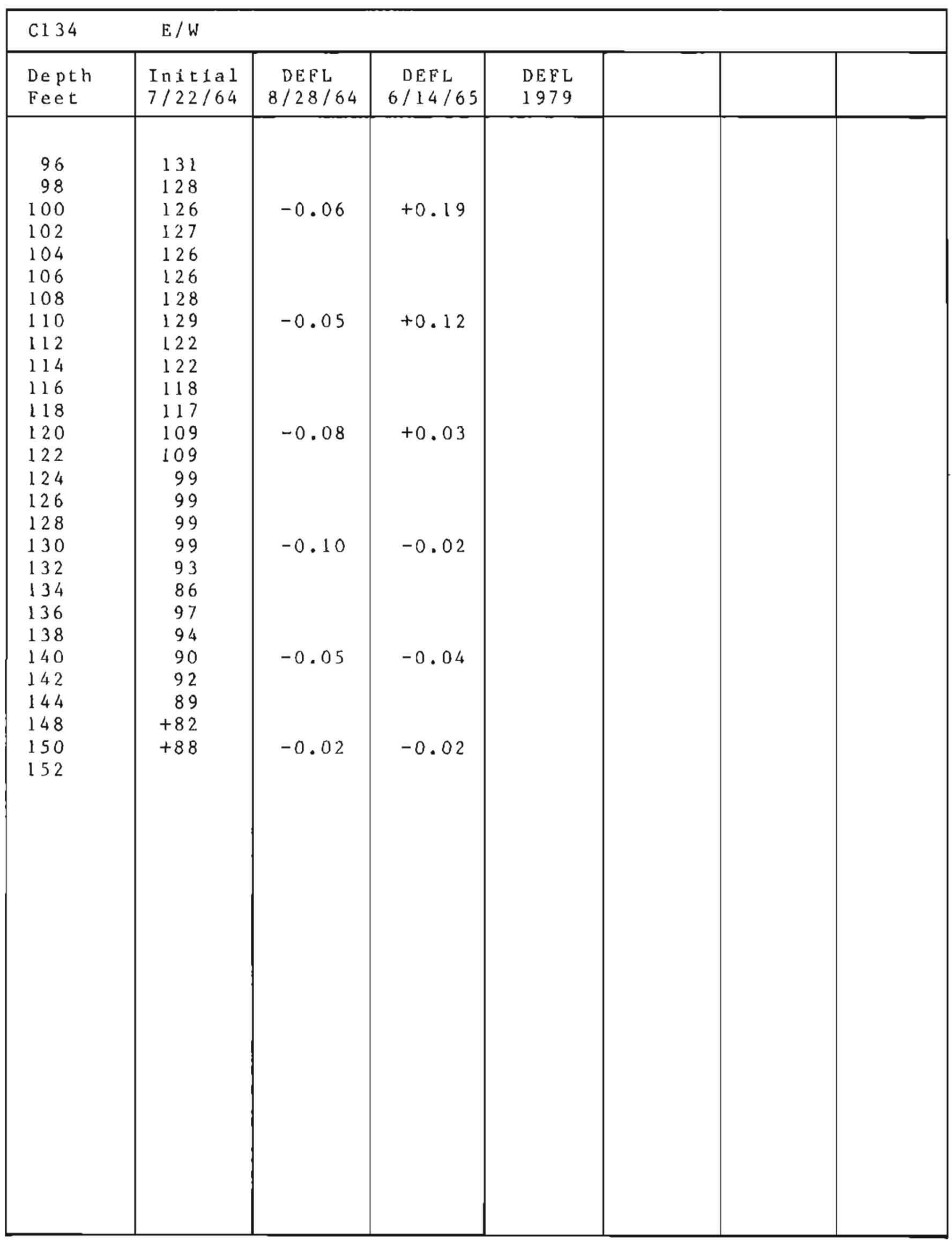




\begin{tabular}{|c|c|c|c|c|c|c|}
\hline $\mathrm{CBS}$ & $N / S$ & & & $E / W$ & & \\
\hline $\begin{array}{l}\text { Depth } \\
\text { Feet }\end{array}$ & $\begin{array}{l}\text { Initial } \\
10 / 15 / 79\end{array}$ & $\begin{array}{l}\text { Indtial } \\
1 / 27 / 81\end{array}$ & $\begin{array}{l}\text { DEFL } \\
1981\end{array}$ & $\begin{array}{l}\text { Inteial } \\
10 / 15 / 79\end{array}$ & $\begin{array}{l}\text { Initial } \\
1 / 27 / 81\end{array}$ & $\begin{array}{l}\text { DEFL } \\
1981\end{array}$ \\
\hline $\begin{array}{l}2 \\
4 \\
6 \\
8 \\
10 \\
12 \\
14 \\
16 \\
18 \\
20 \\
22 \\
24 \\
26 \\
28 \\
30 \\
32 \\
34 \\
36 \\
38 \\
40 \\
42 \\
44 \\
46 \\
48 \\
50 \\
52 \\
54 \\
56 \\
58 \\
60 \\
62 \\
64 \\
66 \\
68\end{array}$ & $\begin{array}{r}536 \\
488 \\
551 \\
449 \\
332 \\
317 \\
294 \\
395 \\
489 \\
461 \\
379 \\
400 \\
287 \\
157 \\
119 \\
94 \\
69 \\
66 \\
47 \\
21 \\
2 \\
-3 \\
24 \\
22 \\
64 \\
131 \\
206\end{array}$ & $\begin{array}{r}460 \\
466 \\
498 \\
509 \\
462 \\
433 \\
438 \\
397 \\
364 \\
358 \\
337 \\
327 \\
200 \\
188 \\
144 \\
115 \\
82 \\
-17 \\
-26 \\
-39 \\
-43 \\
-36 \\
46 \\
60 \\
113 \\
168 \\
210 \\
395 \\
452 \\
416 \\
415 \\
292 \\
451 \\
642\end{array}$ & $\begin{array}{l}-0.110 \\
-0.055 \\
-0.215 \\
-0.051 \\
-0.007 \\
+0.054 \\
+0.025 \\
+0.002\end{array}$ & $\begin{array}{l}-1083 \\
-1038 \\
-\quad 390 \\
-\quad 326 \\
-\quad 290 \\
-\quad 257 \\
-\quad 242 \\
-195 \\
-\quad 202 \\
-\quad 203 \\
-145 \\
-\quad 59 \\
182 \\
190 \\
215 \\
244 \\
281 \\
367 \\
323 \\
340 \\
373 \\
382 \\
615 \\
657 \\
704 \\
709 \\
655\end{array}$ & $\begin{array}{r}-569 \\
-541 \\
-614 \\
-595 \\
-574 \\
-535 \\
-489 \\
-250 \\
-213 \\
-168 \\
-81 \\
14 \\
254 \\
224 \\
216 \\
225 \\
274 \\
415 \\
386 \\
406 \\
433 \\
434 \\
656 \\
634 \\
598 \\
578 \\
583 \\
435 \\
441 \\
439 \\
431 \\
429 \\
436 \\
484\end{array}$ & $\begin{array}{l}-0.133 \\
-0.384 \\
+0.014 \\
-0.022 \\
-0.074 \\
-0.191 \\
-0.122 \\
-0.043\end{array}$ \\
\hline
\end{tabular}




\section{Appendix C \\ COMPARATIVE CASING-STRAIN PROFILES}

Appendix $C$ presents a comparison of the apparent changes in the casing profiles that occurred since the initial calibration readings made in 1964.

The initial profile is plotted as a straight vertical line, indicated by the 0 , or zero point. The curves represent the deflection Prom the initial point for successive depths.

The year in which the readings were obtained is indicaled on each curve. Usually, an inclinometer survey was made a few months after the initial survey readings and is indicated as '1964'. However, many casings were buried or destroyed in 1964-1965, and no further readings were obtained. Casings A112S and A1005S were installed in 1977, which accounts for their brief hislory.

The horizontal variance (strain) with respect to depth is given in inches from the initial zero condttion. $\mathrm{BH}$ is base of the hole. 


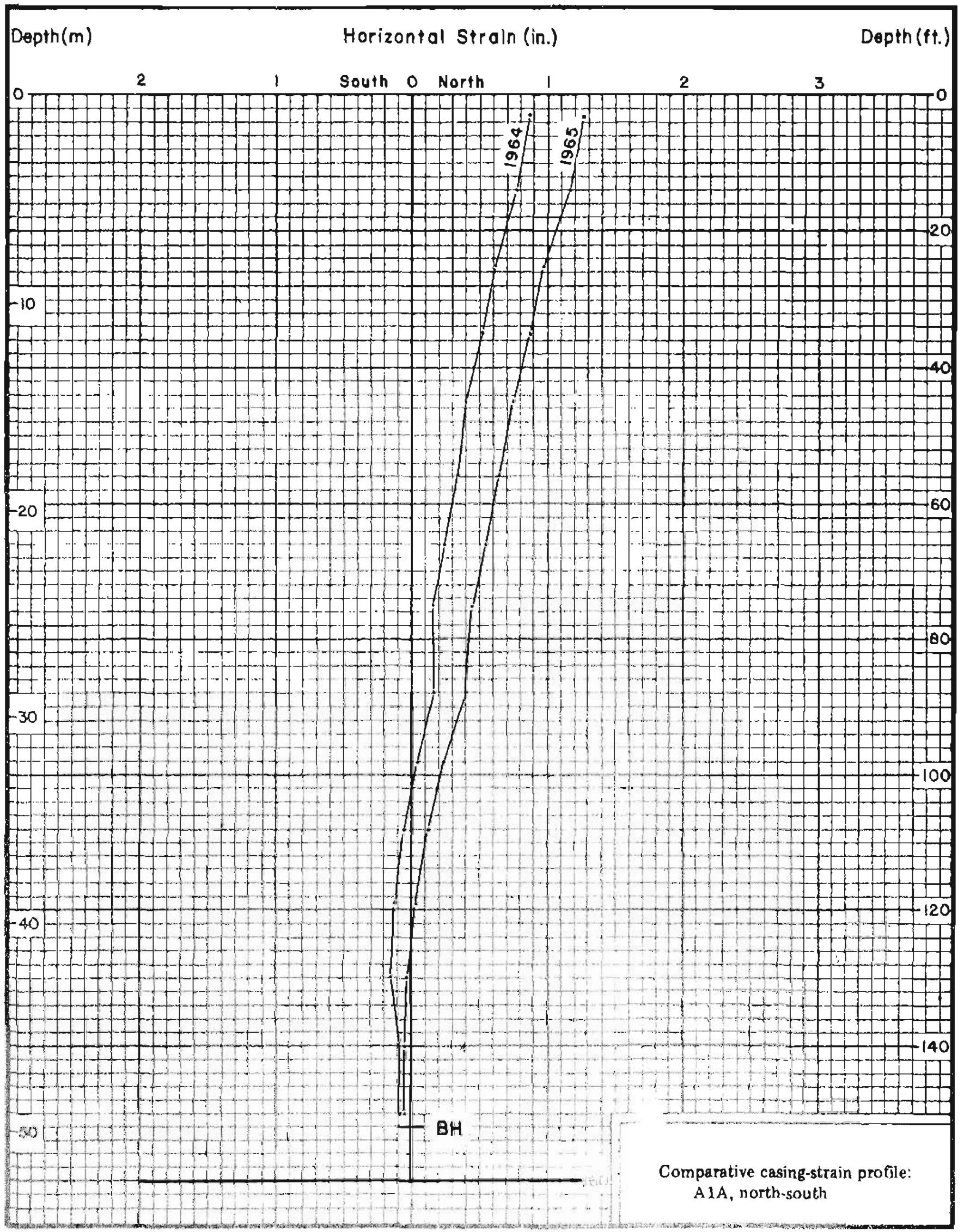




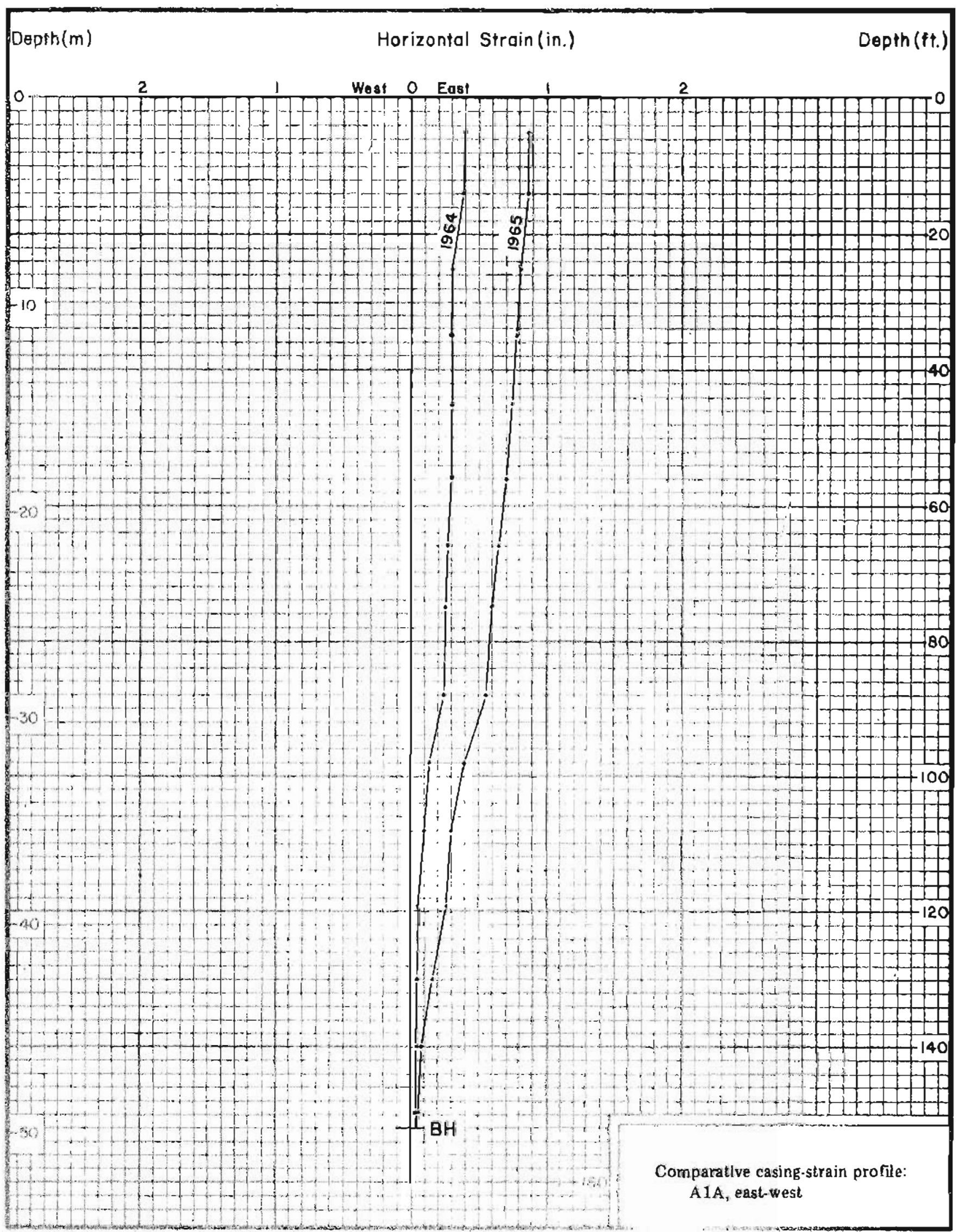




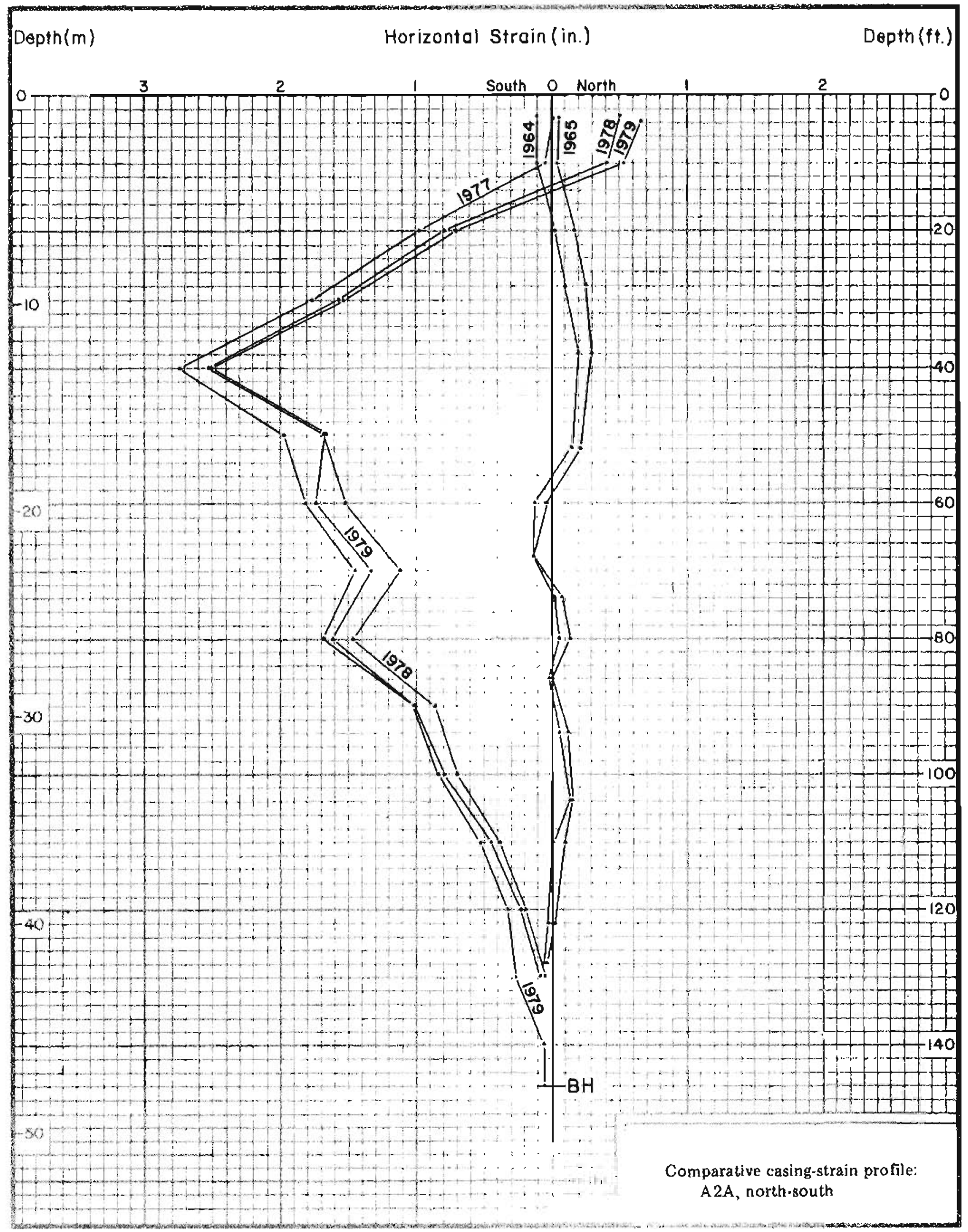




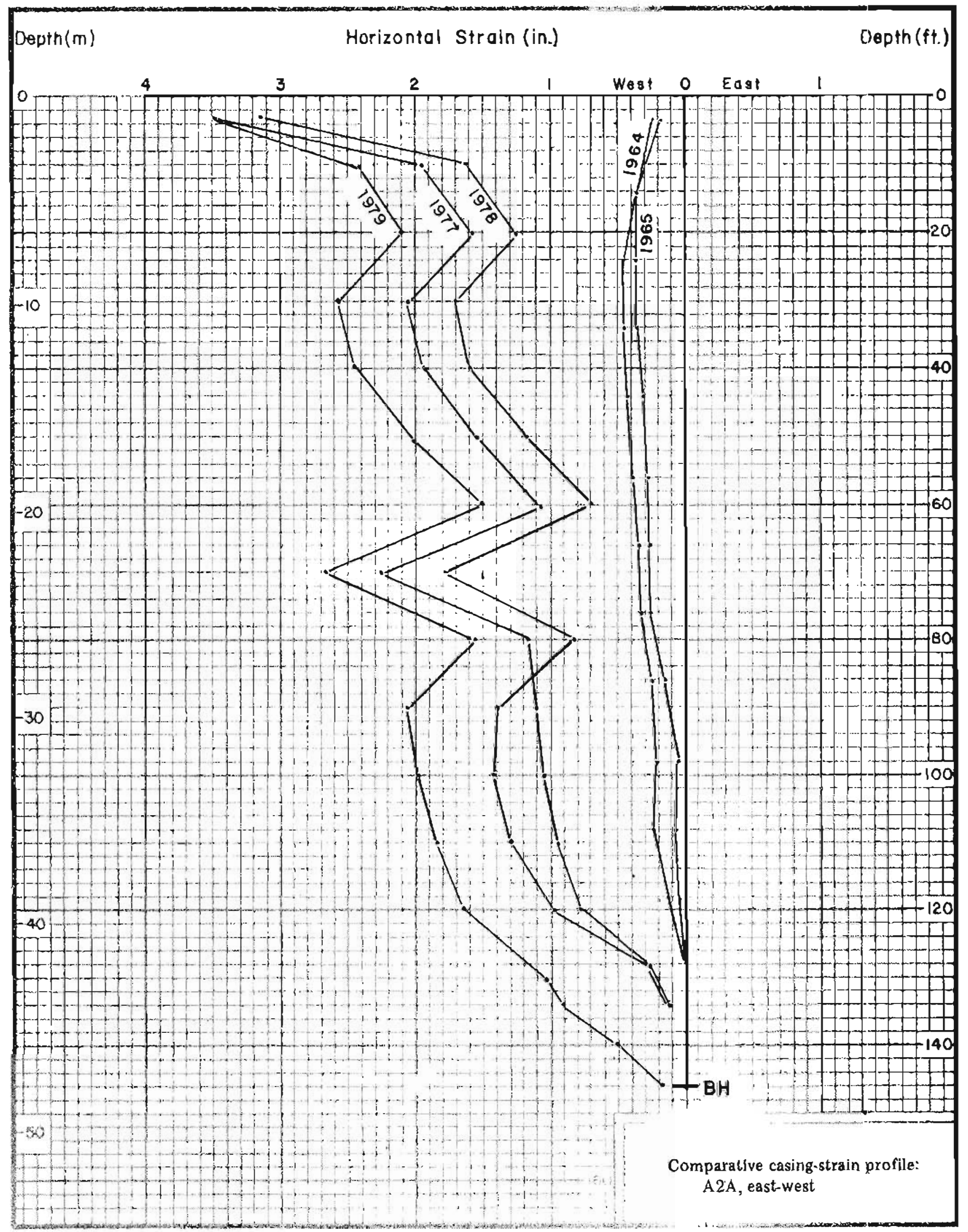




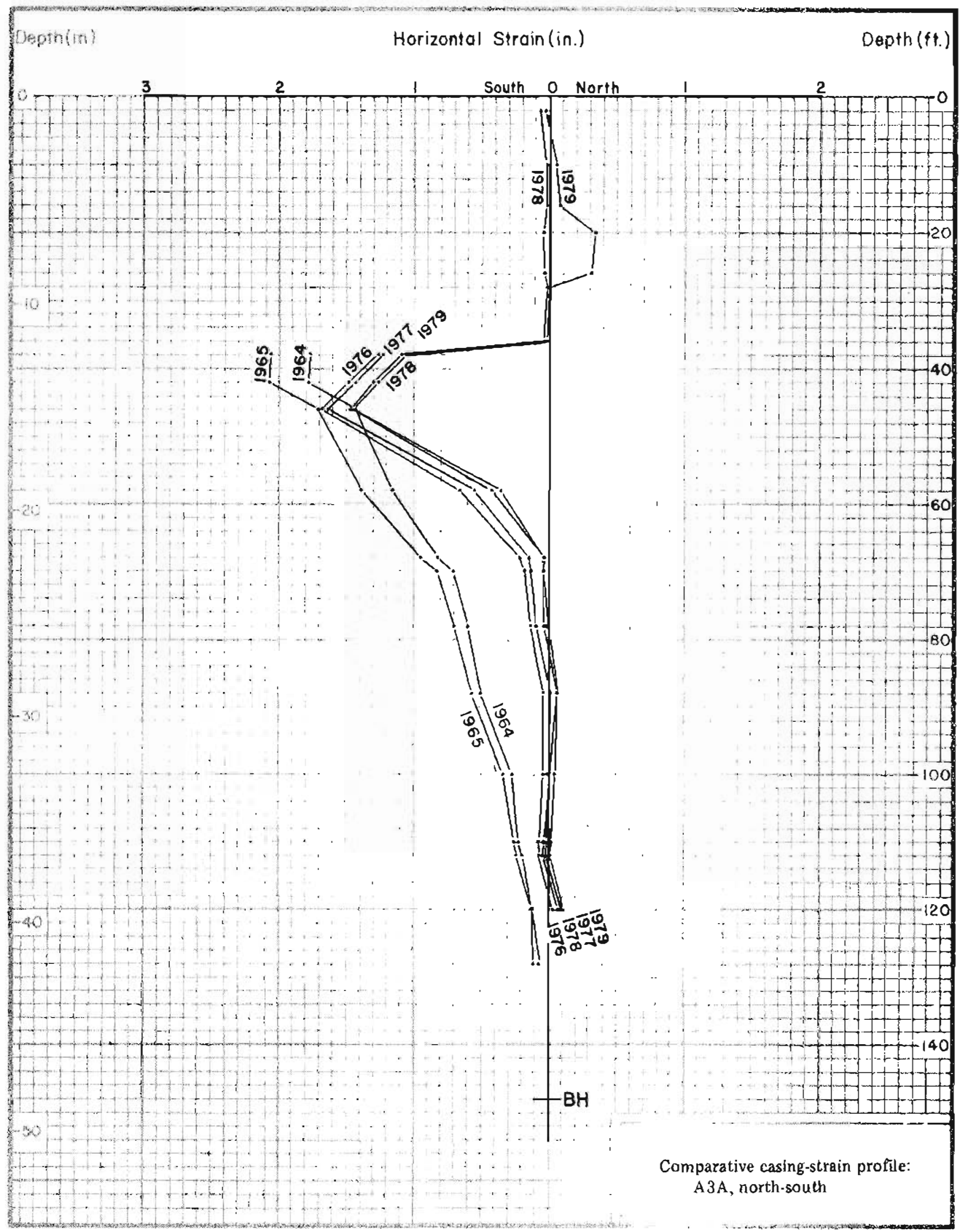


PROFESSYONAL REPORT 80

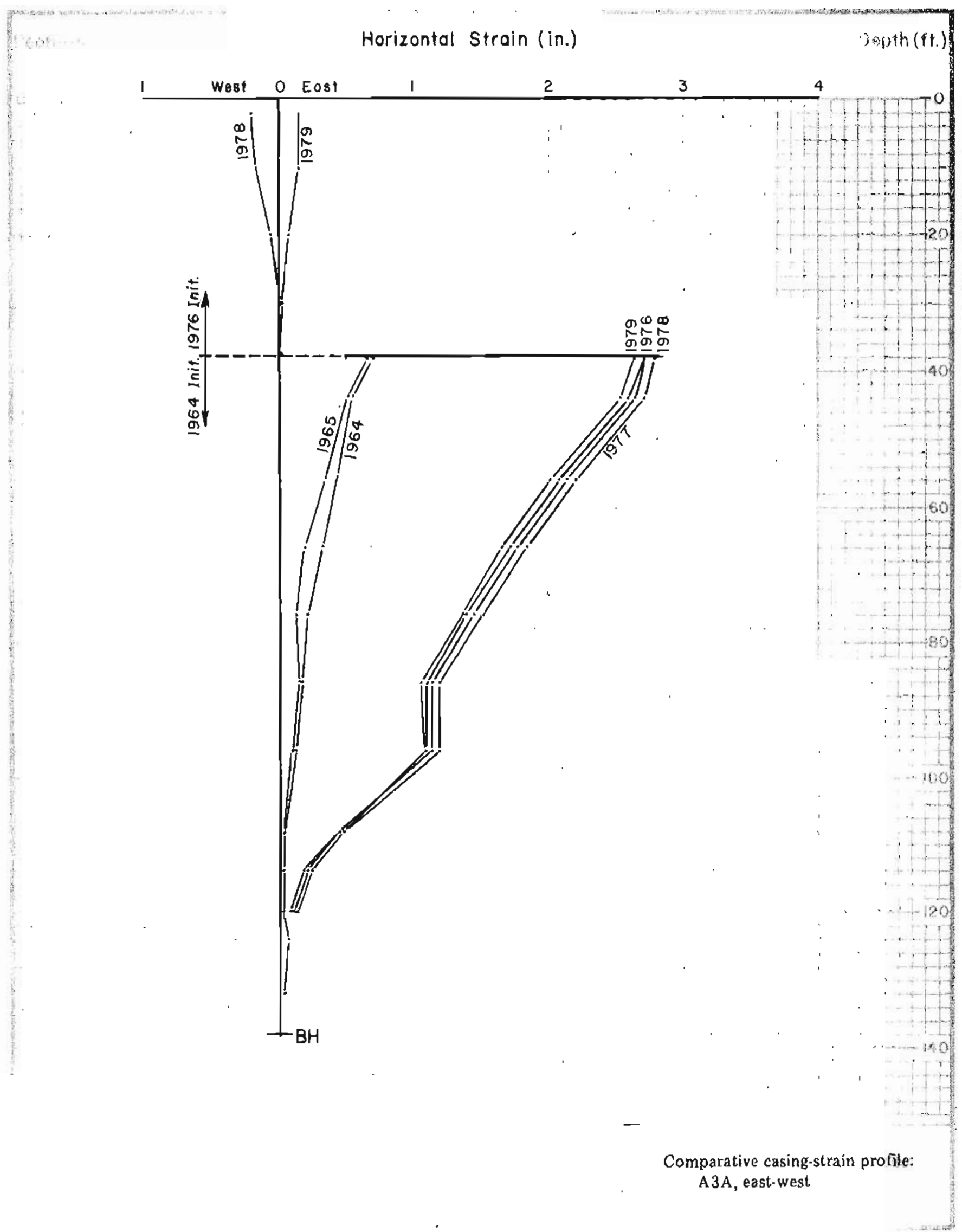




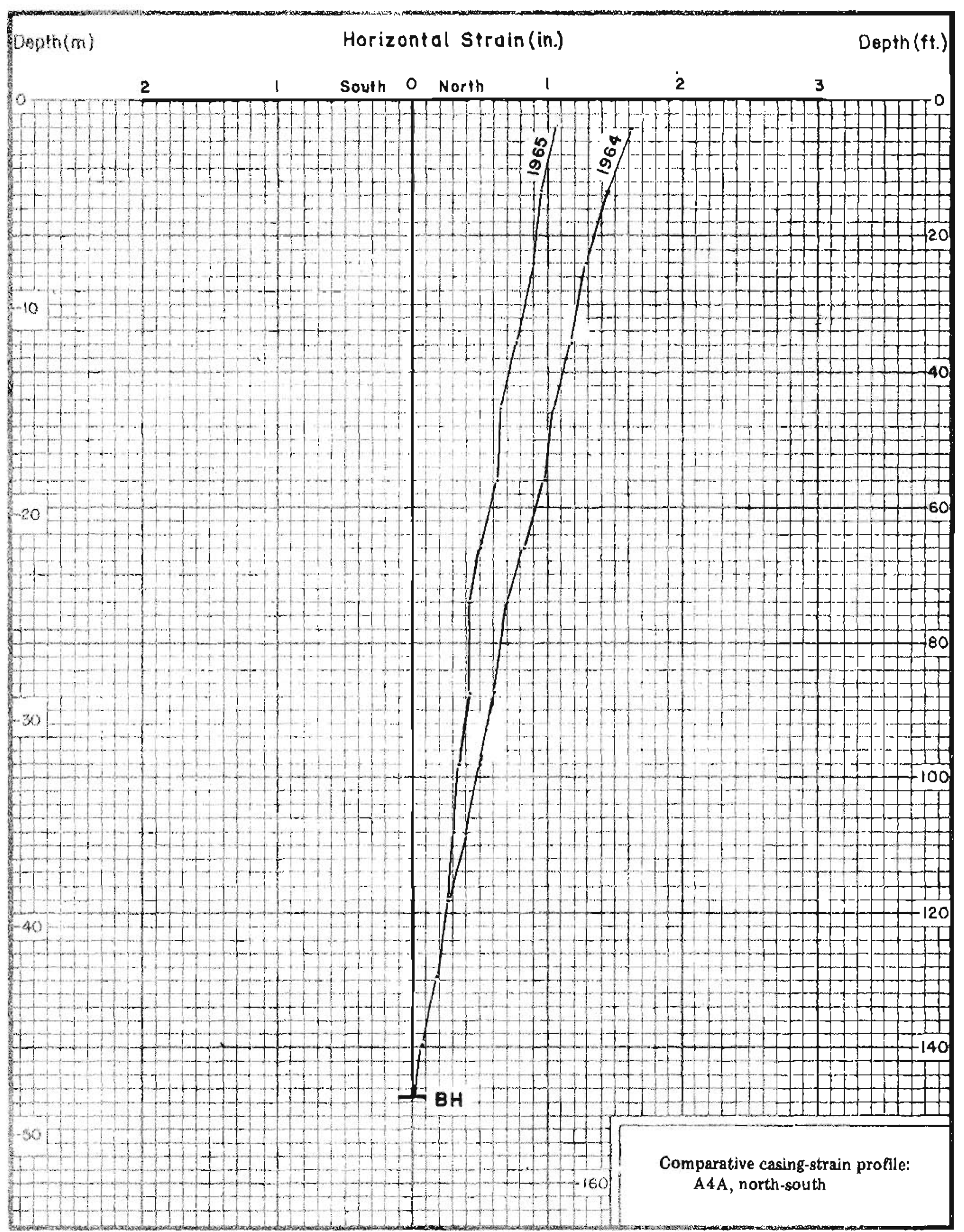




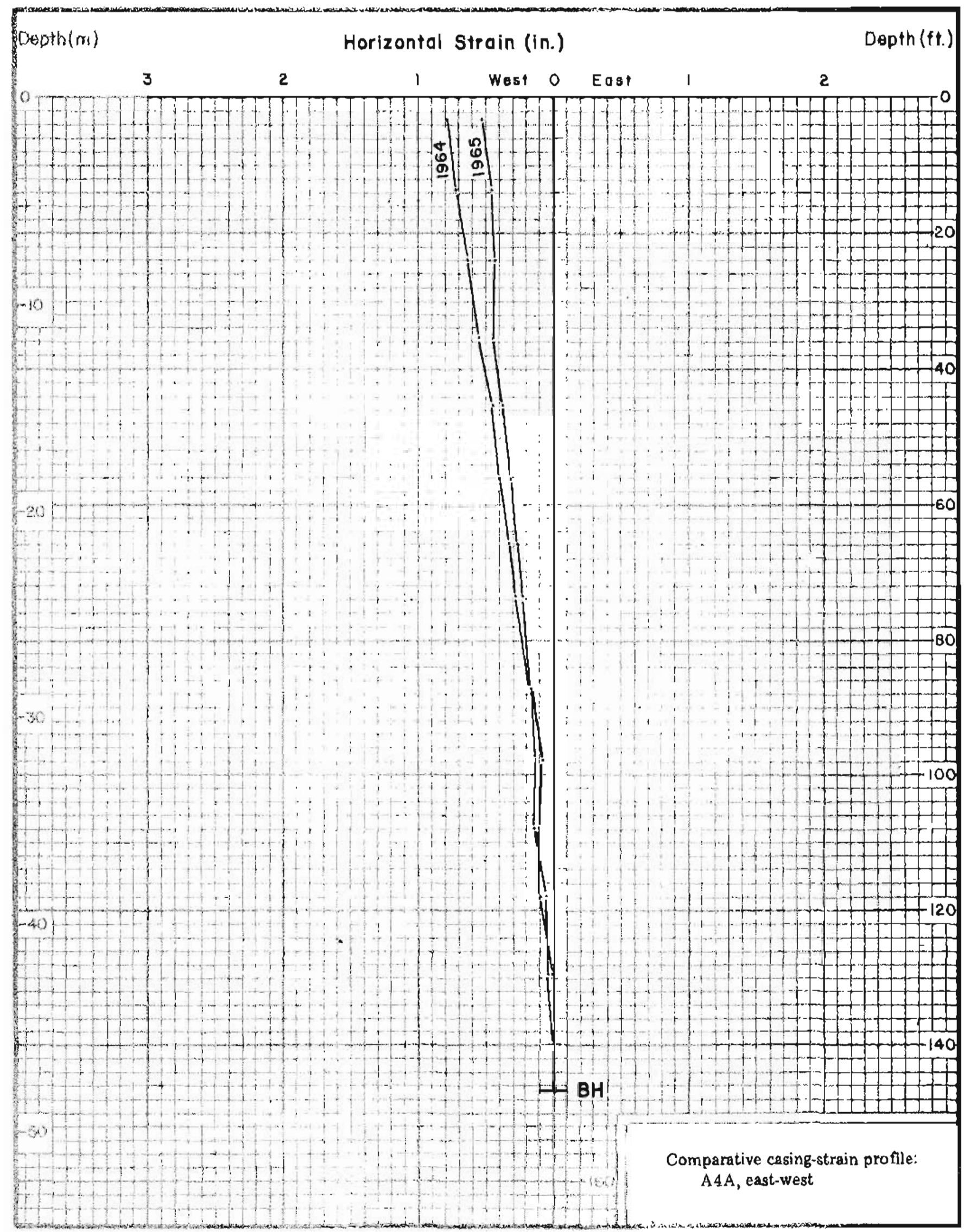




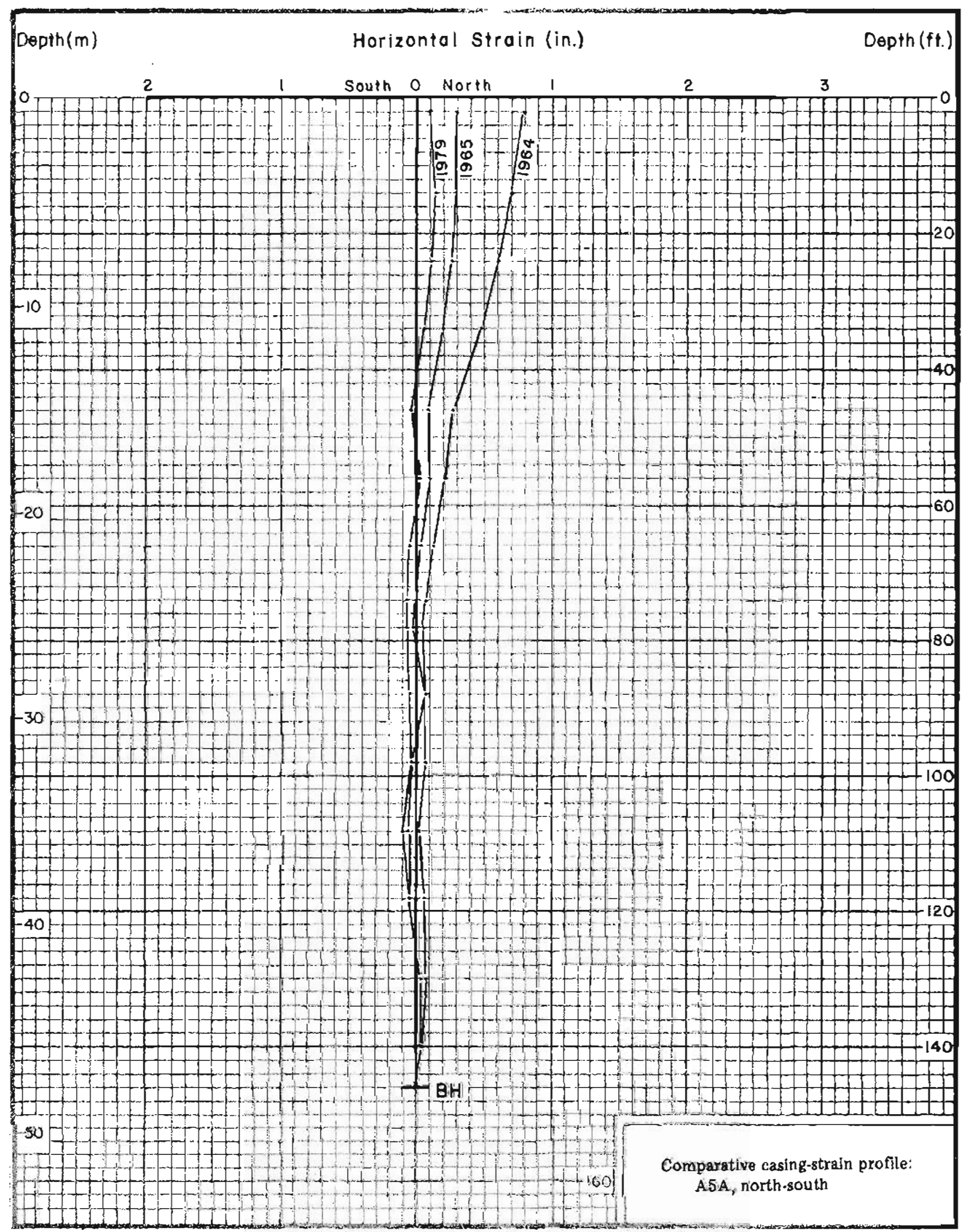




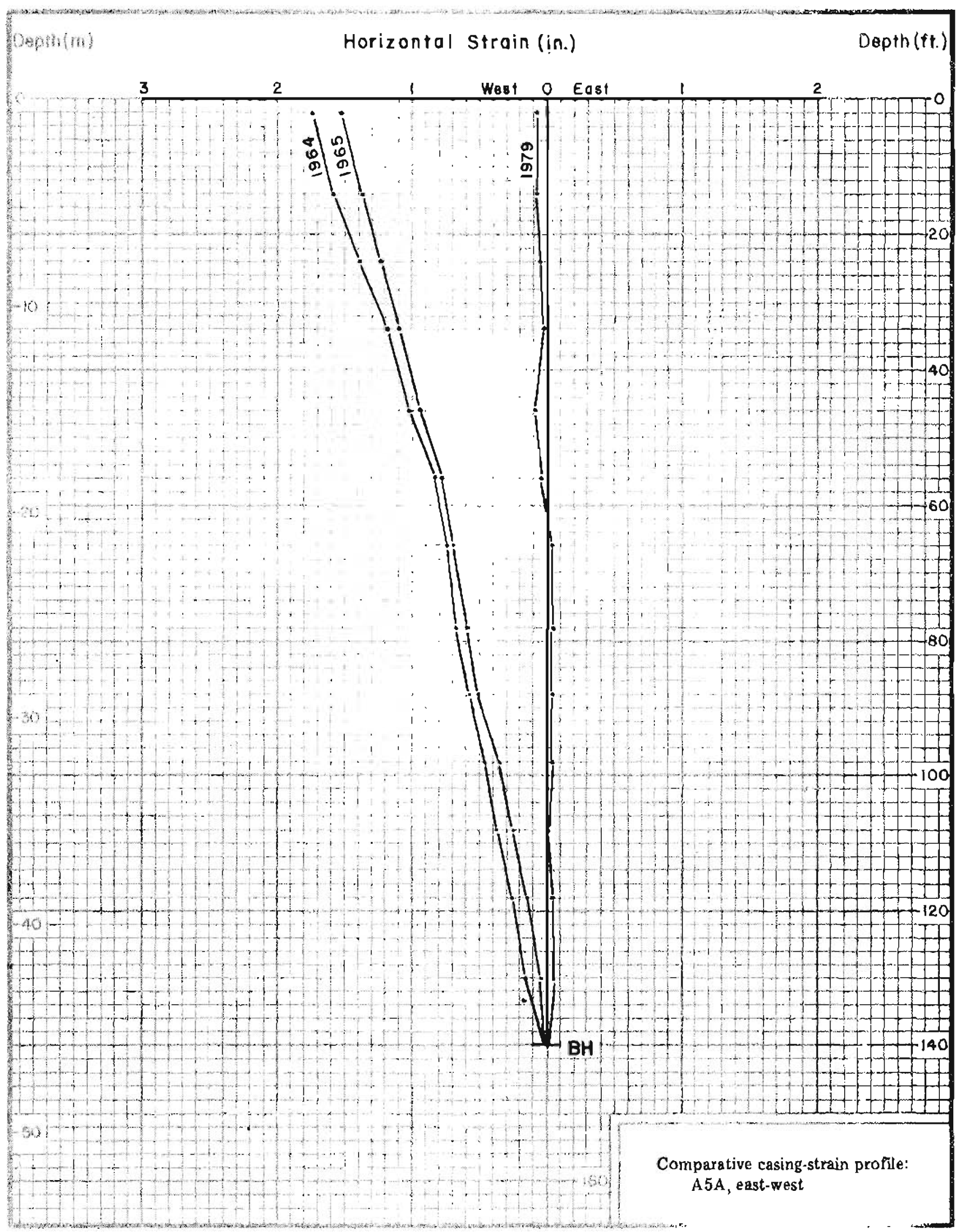




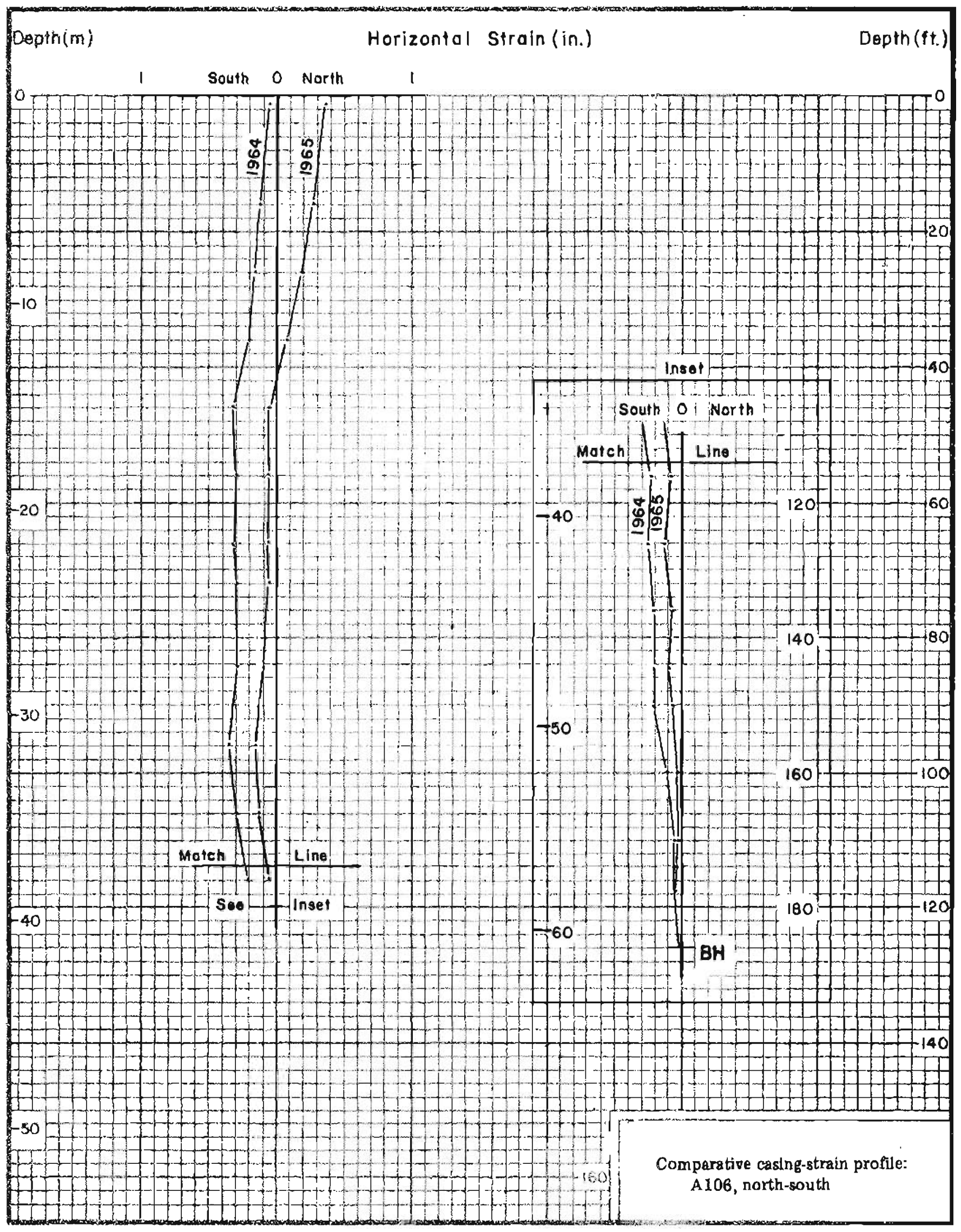




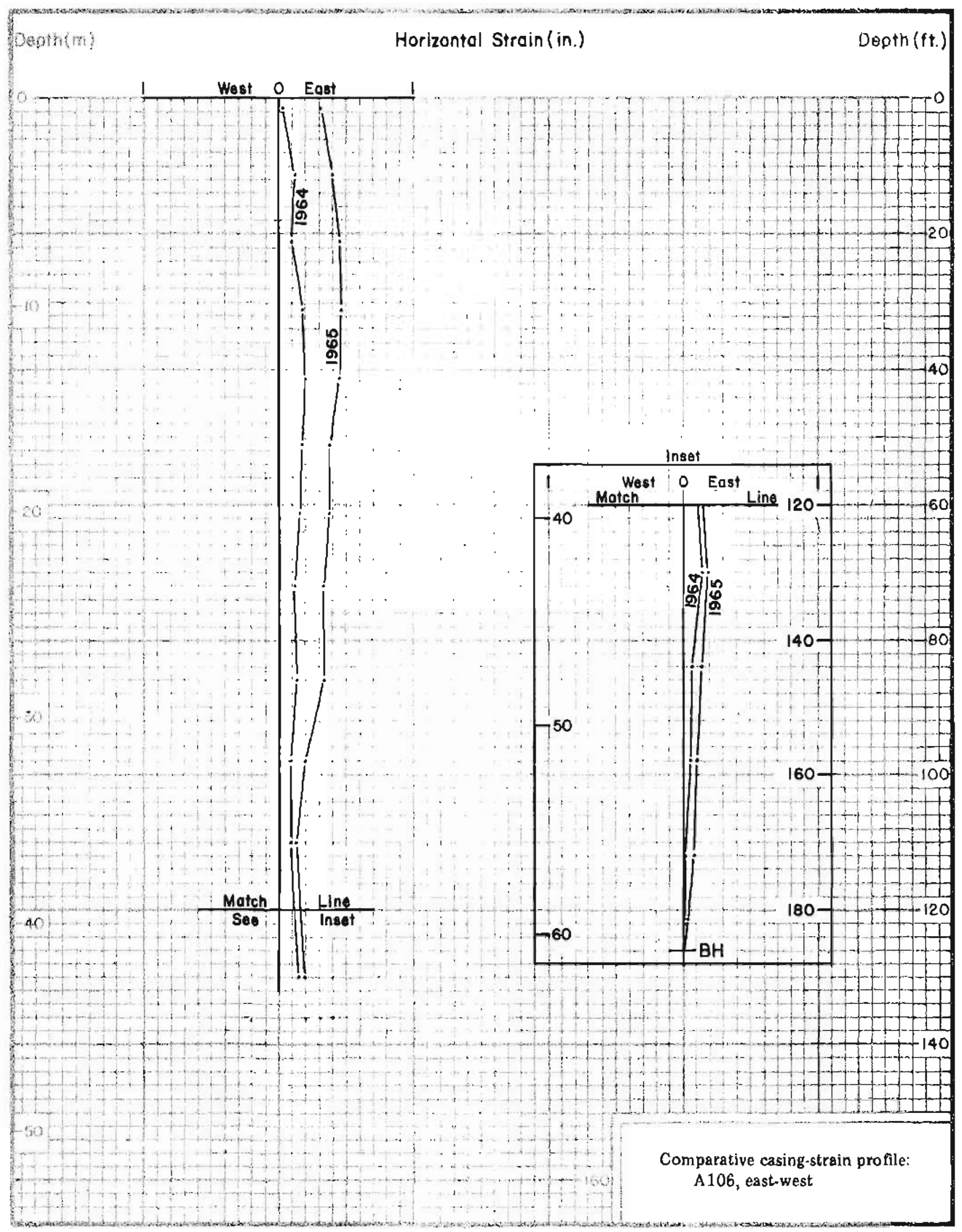




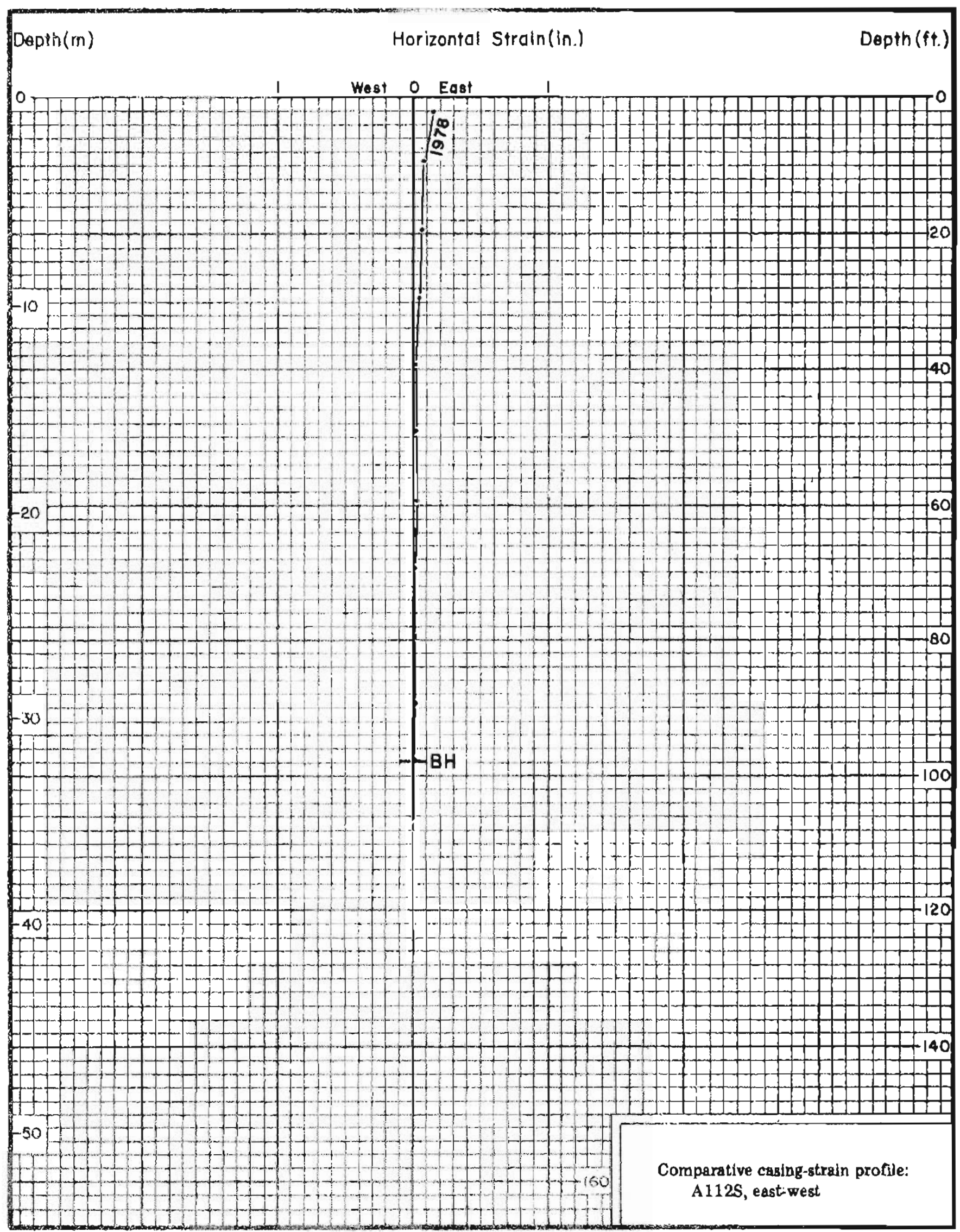




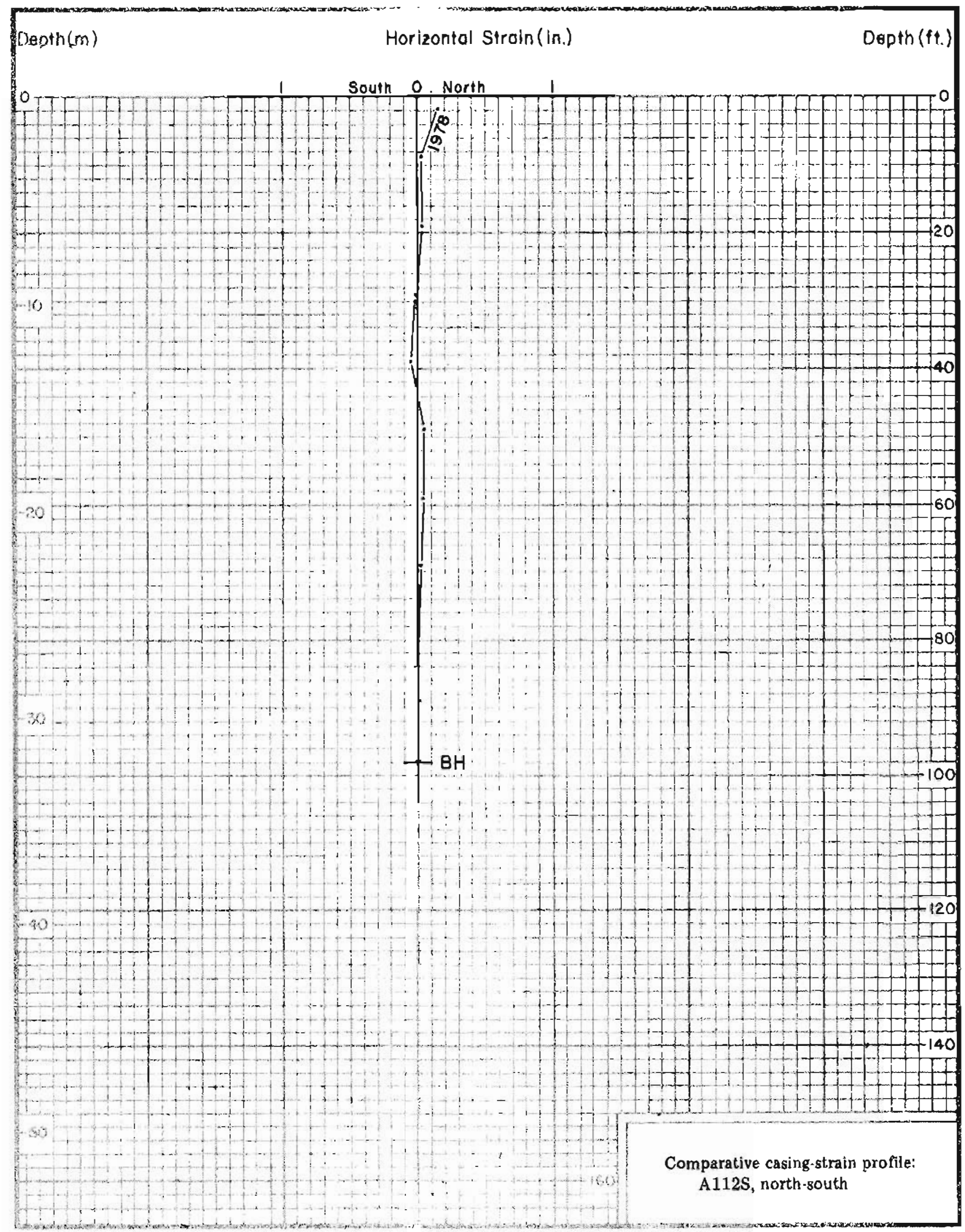




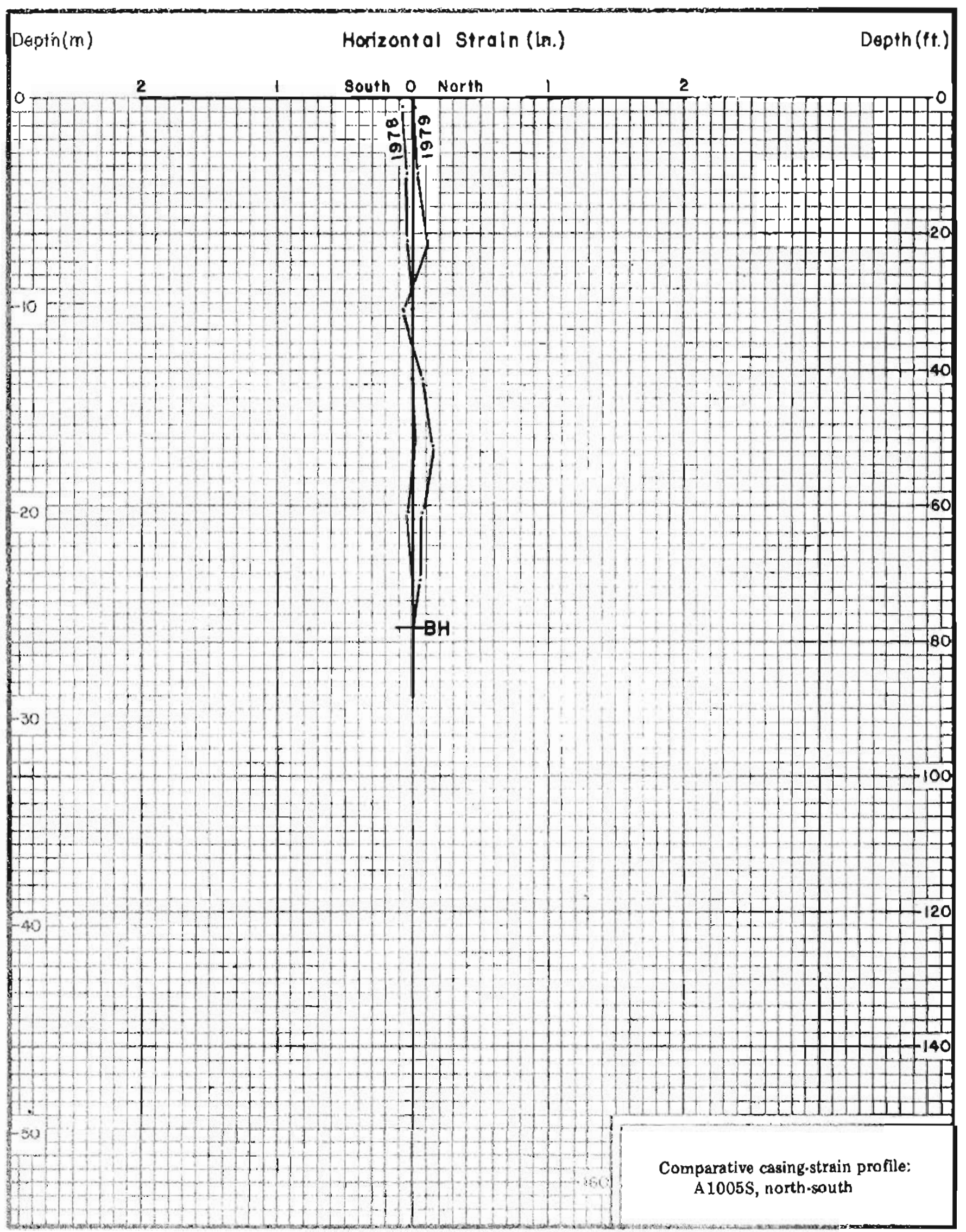




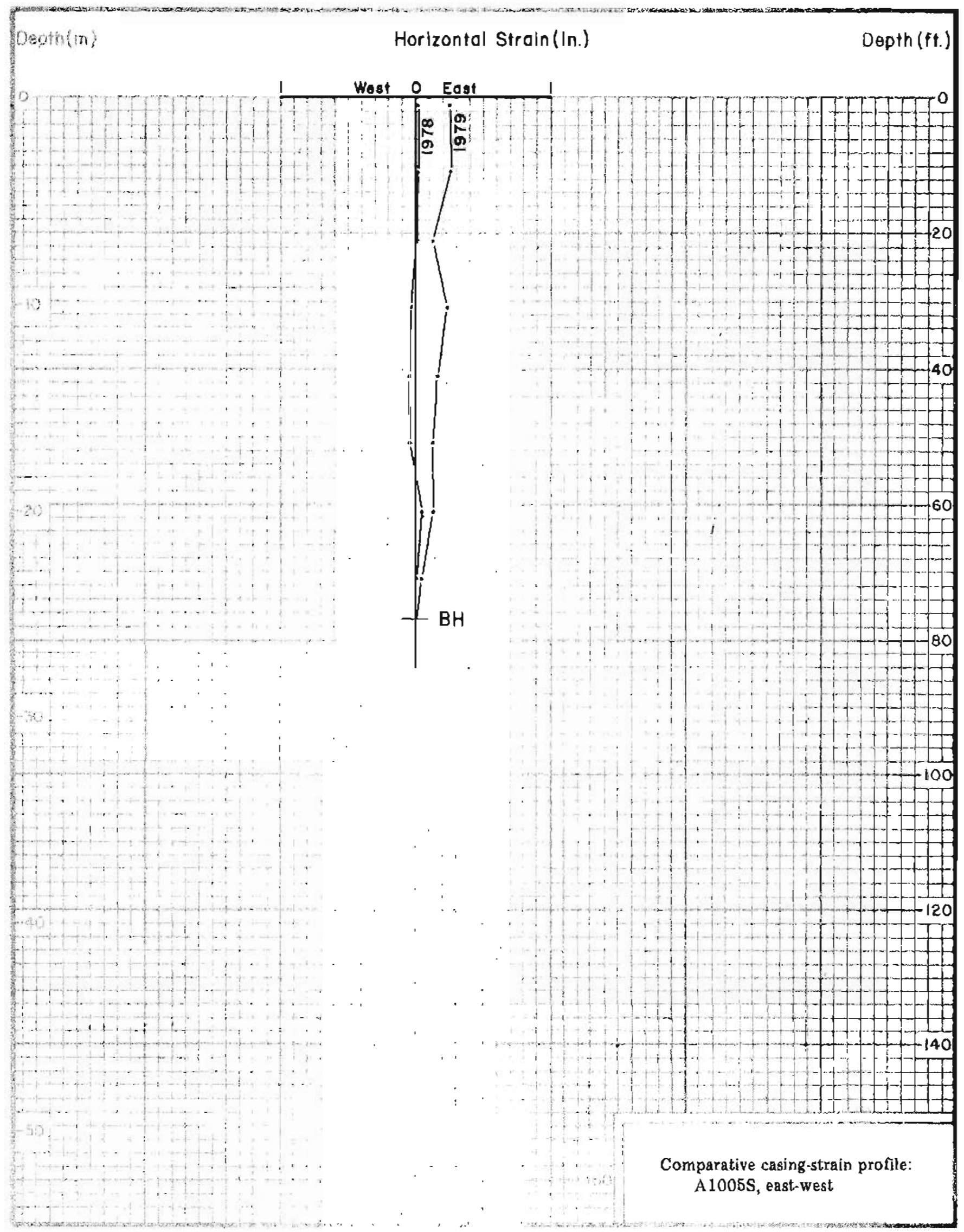




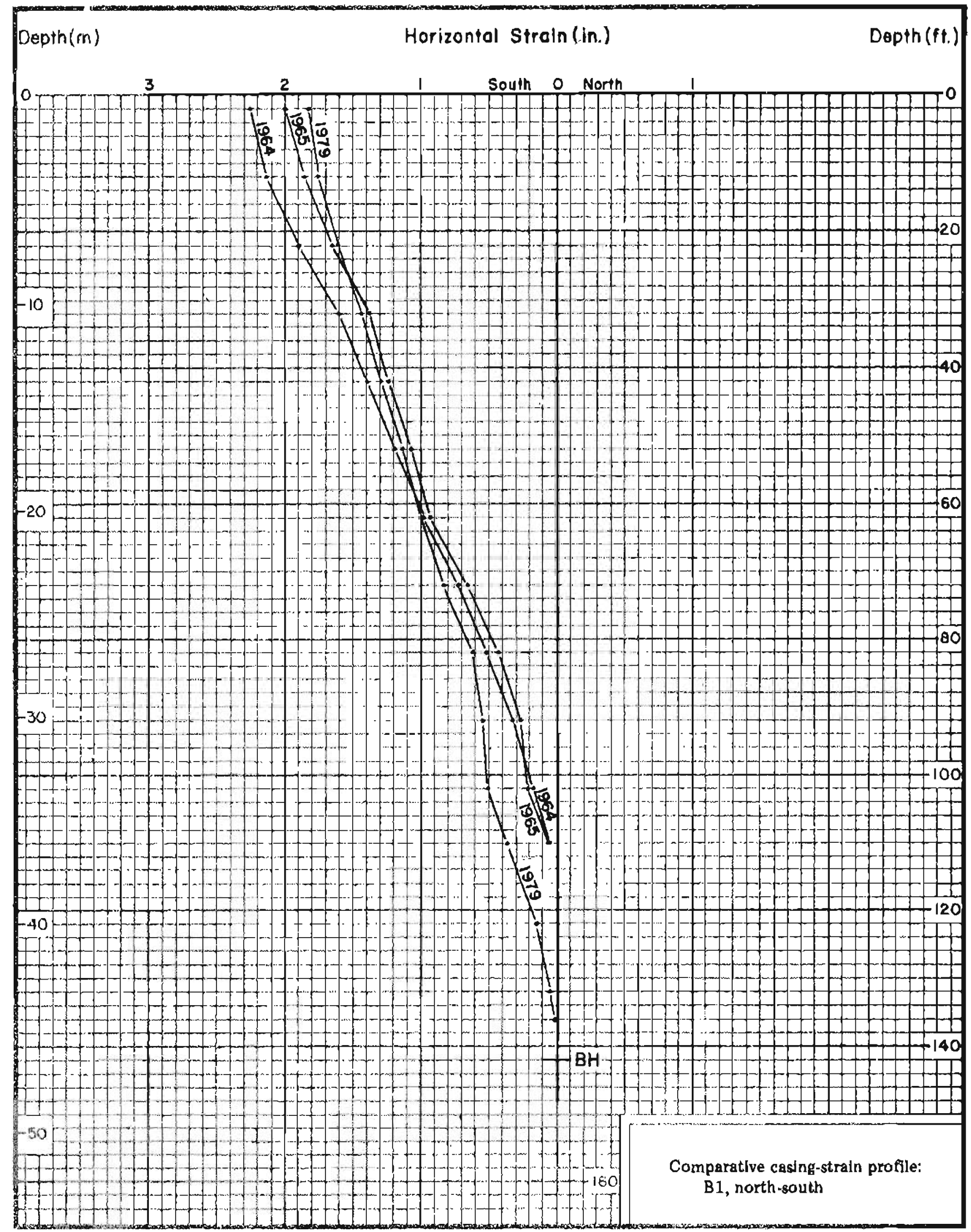




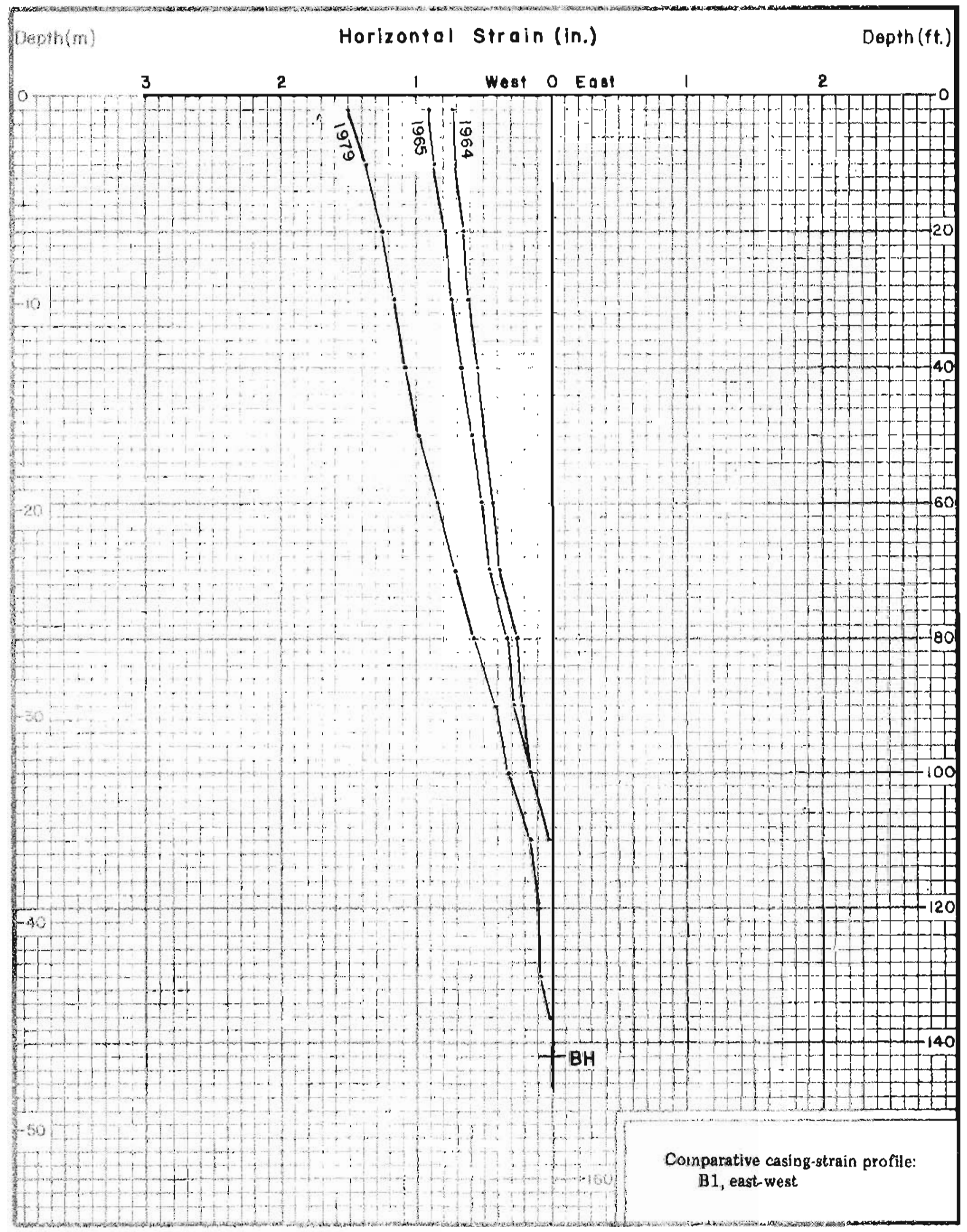




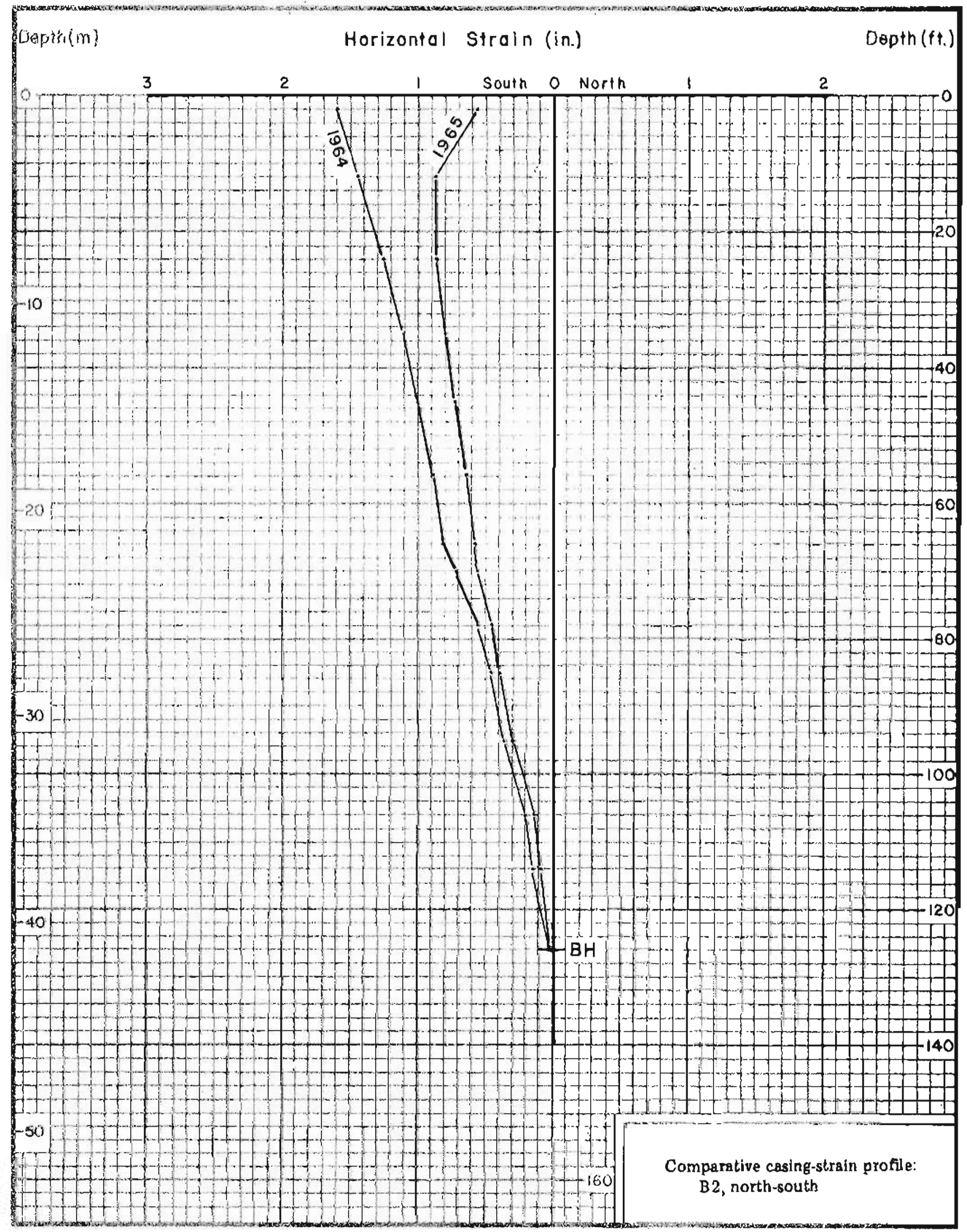


PROFESSIONAL REPORT 80

121

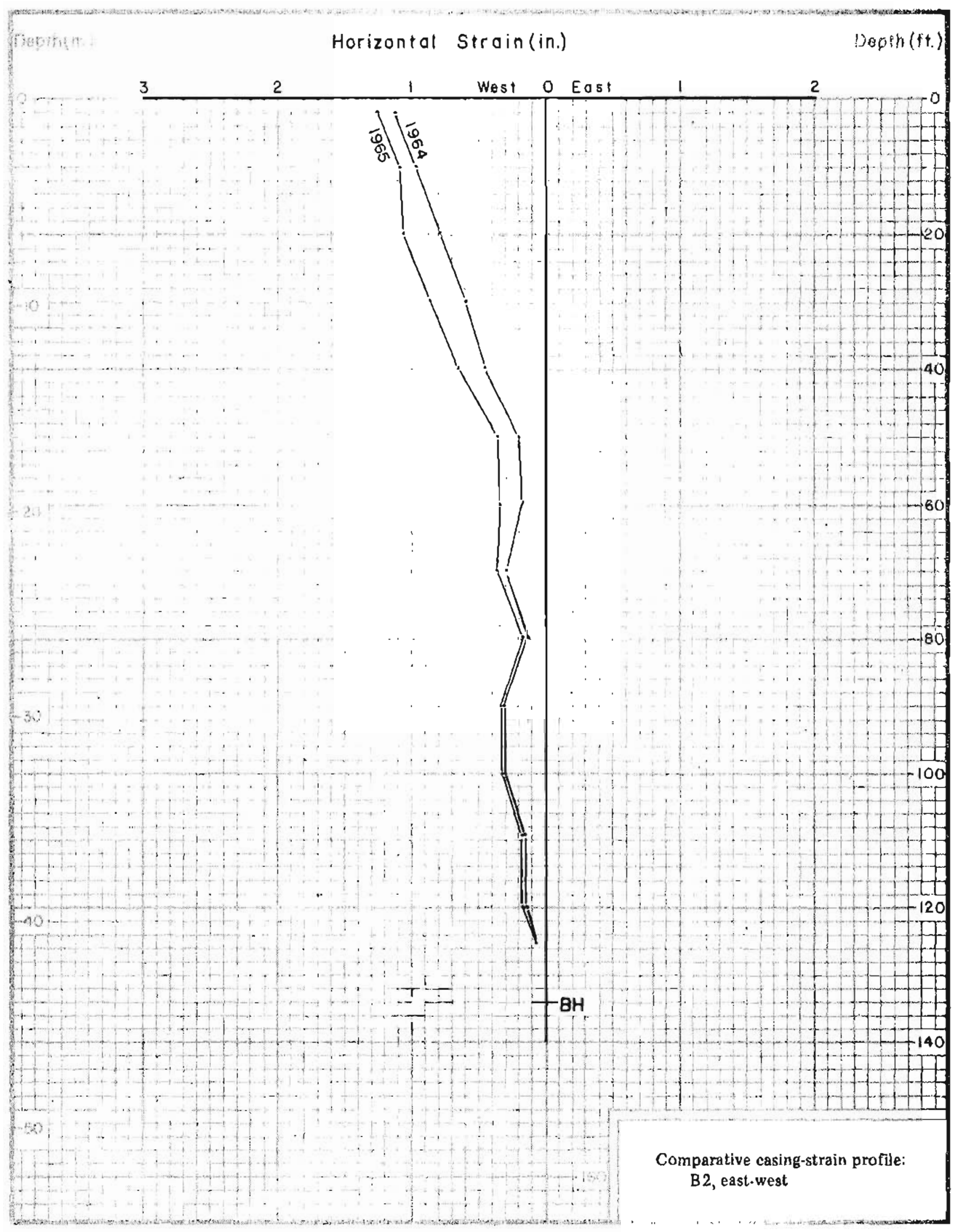




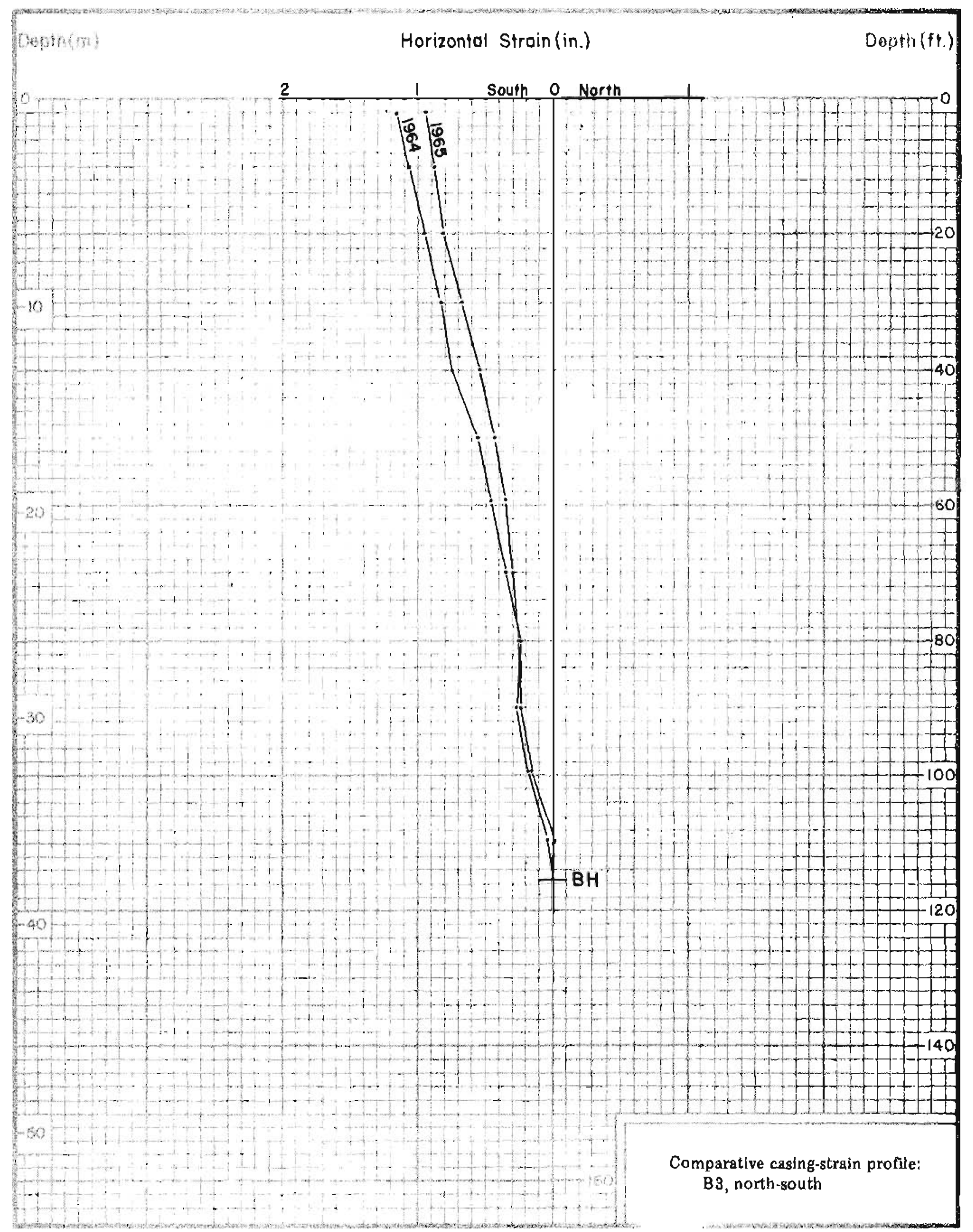


PROFESSIONAL REPORT 80

123

Horizontal Strain(in.)

$$
\text { (1) spesn (fft.) }
$$

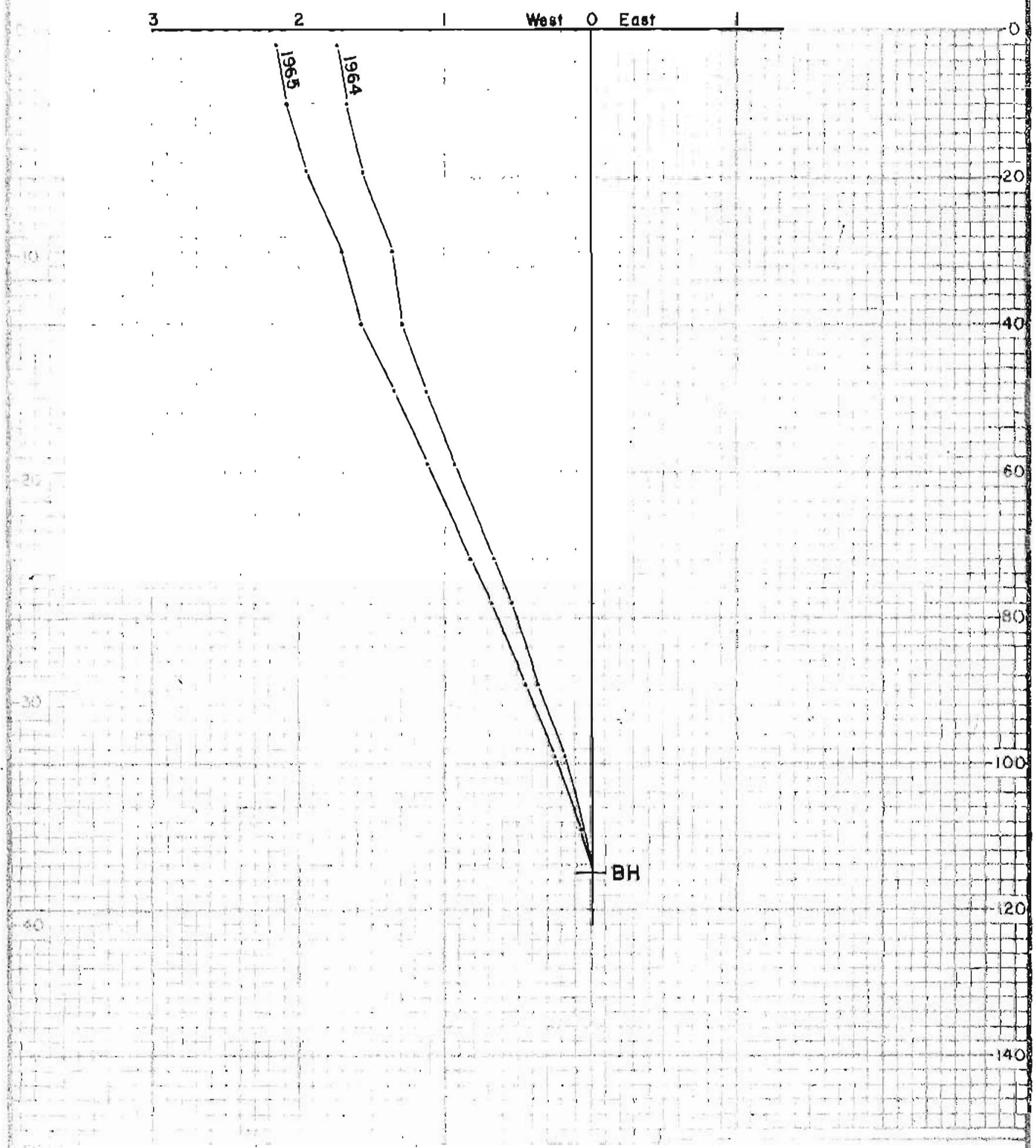

Comparative casing-strain profile: $B 3$, east-west 


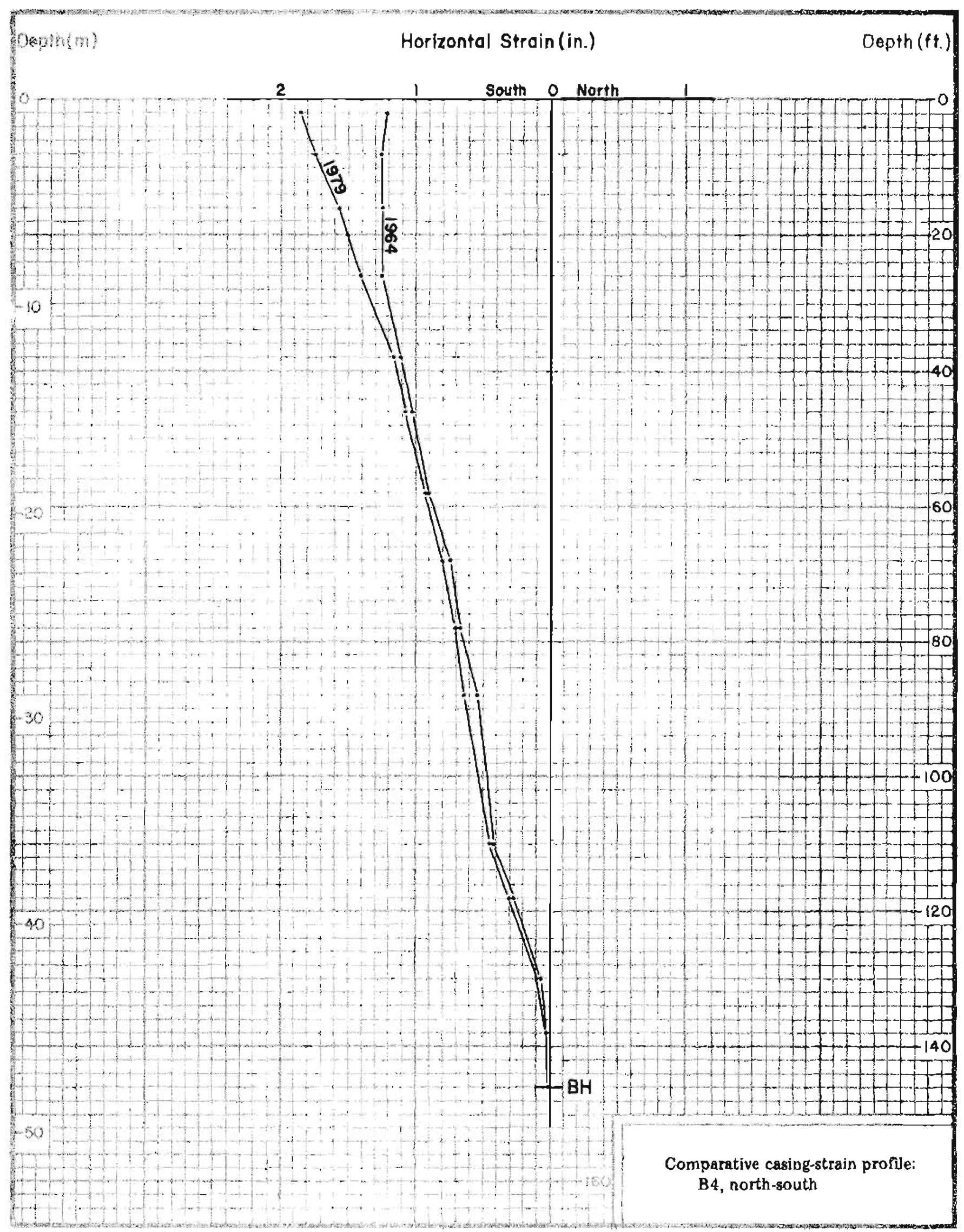




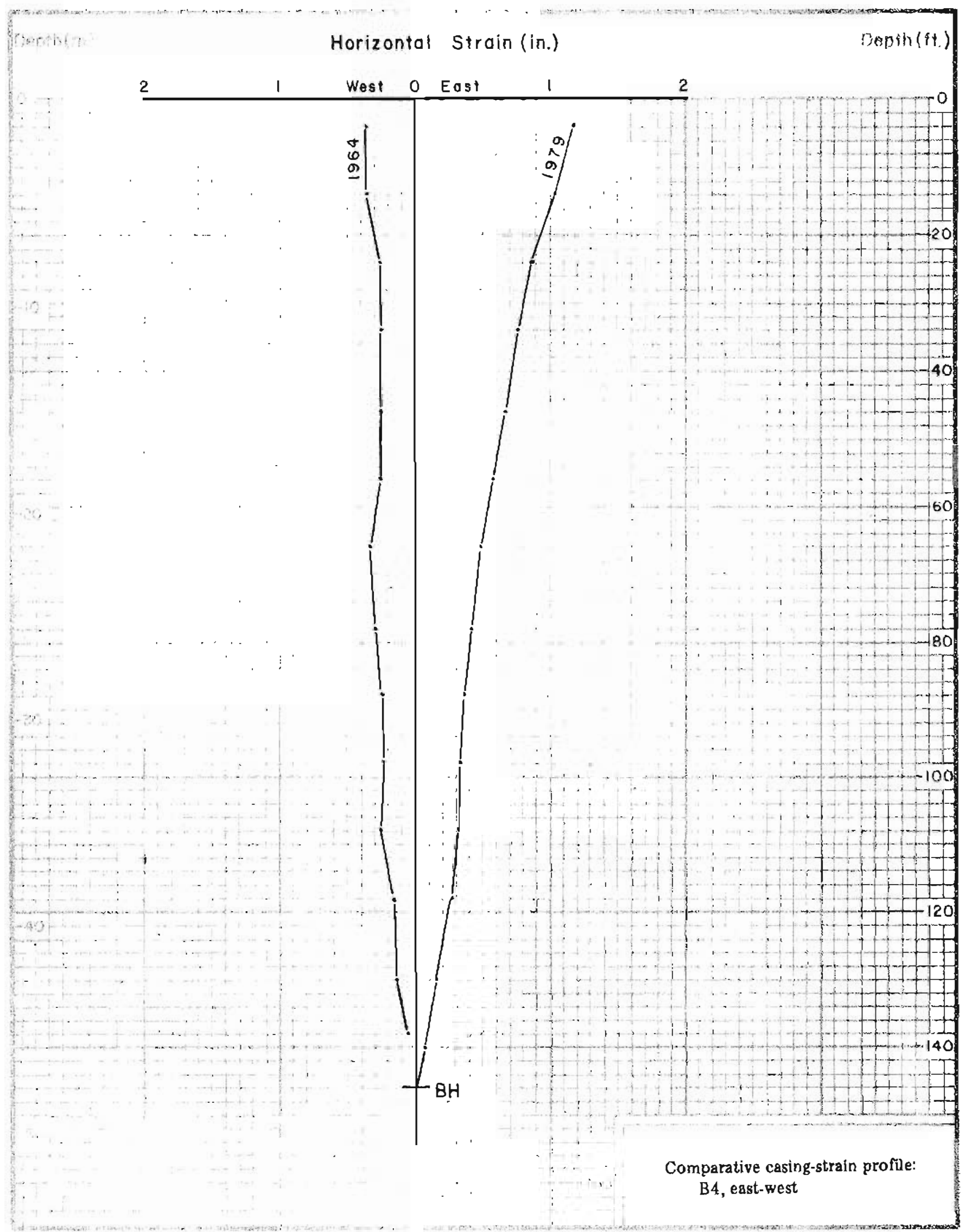




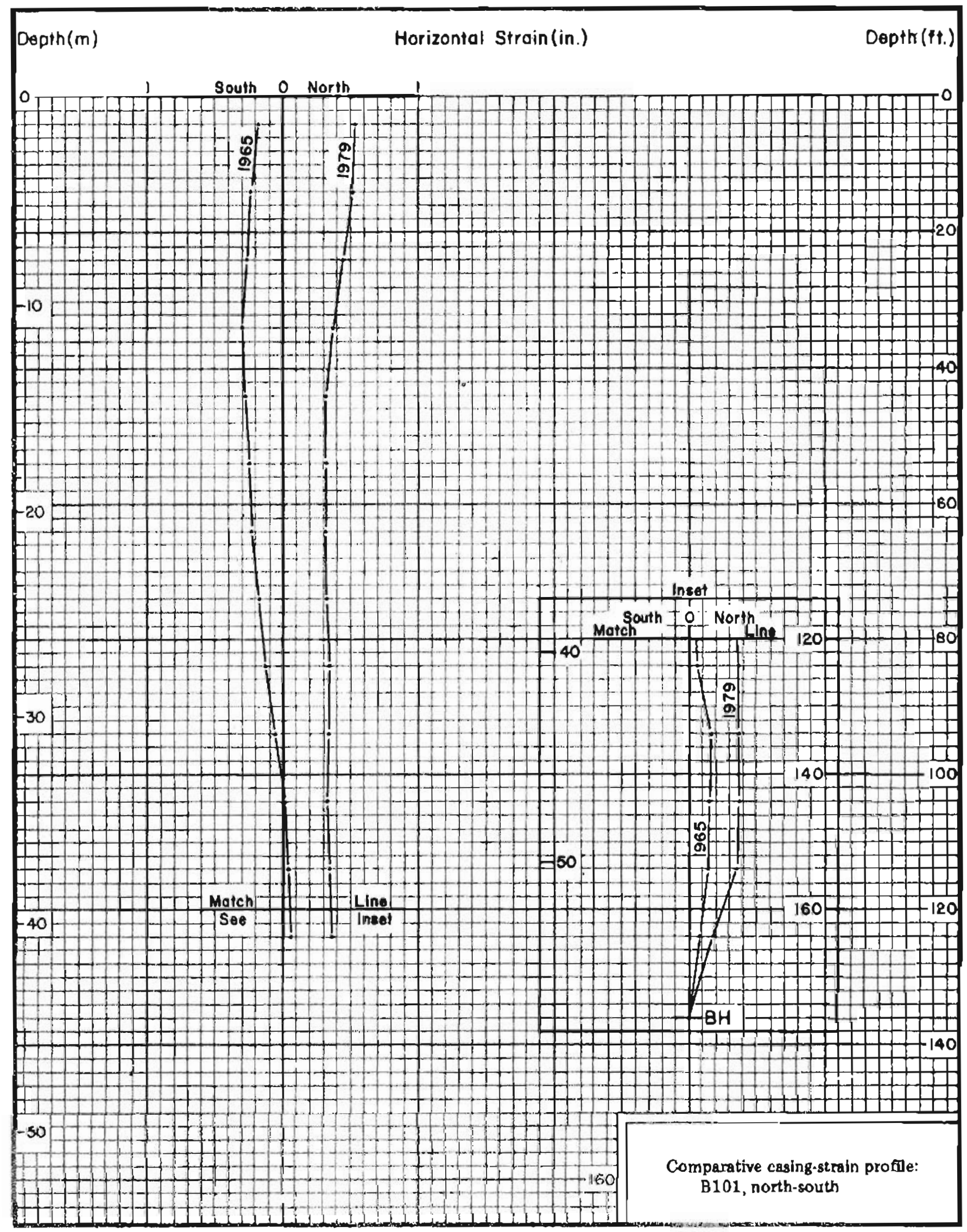




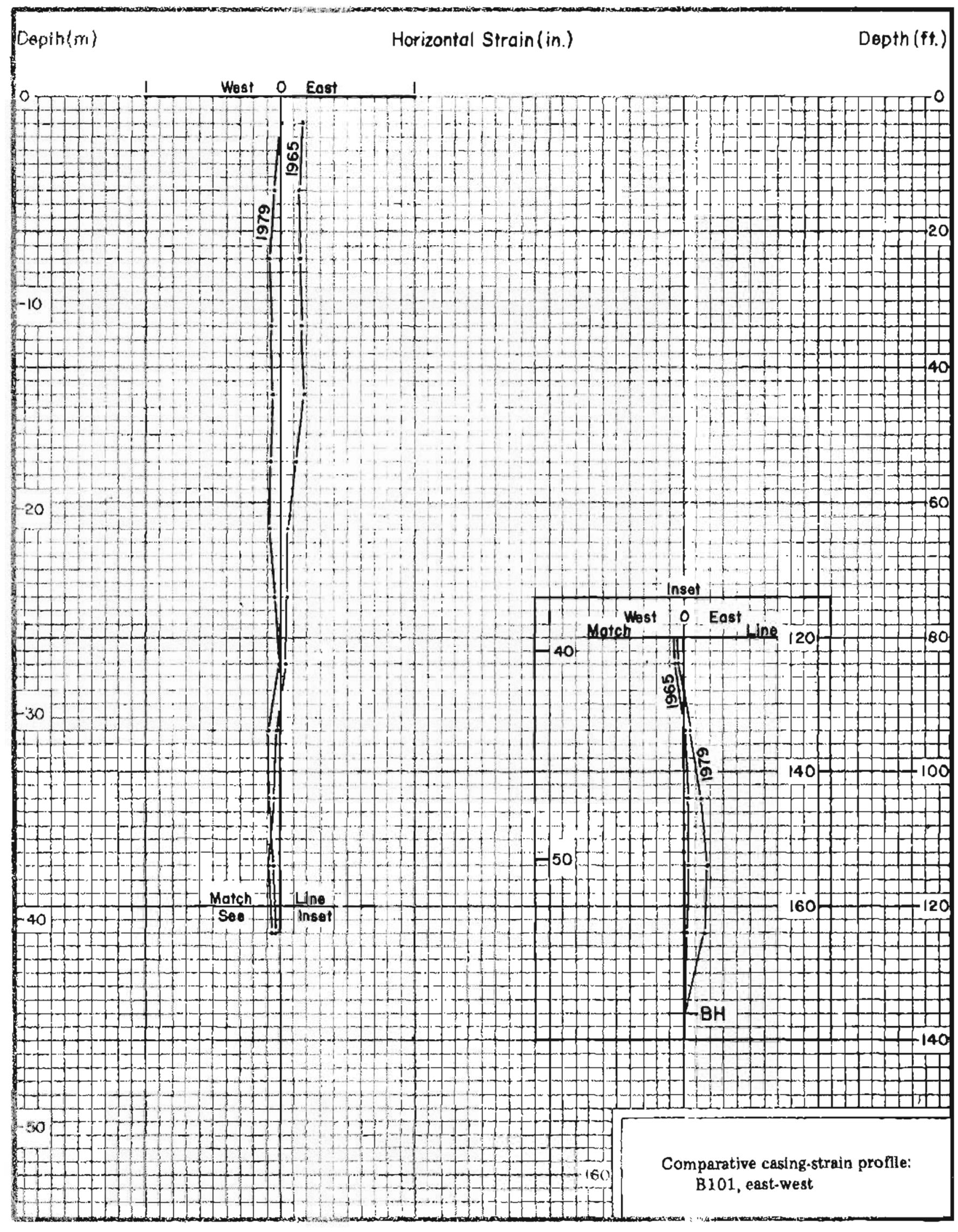




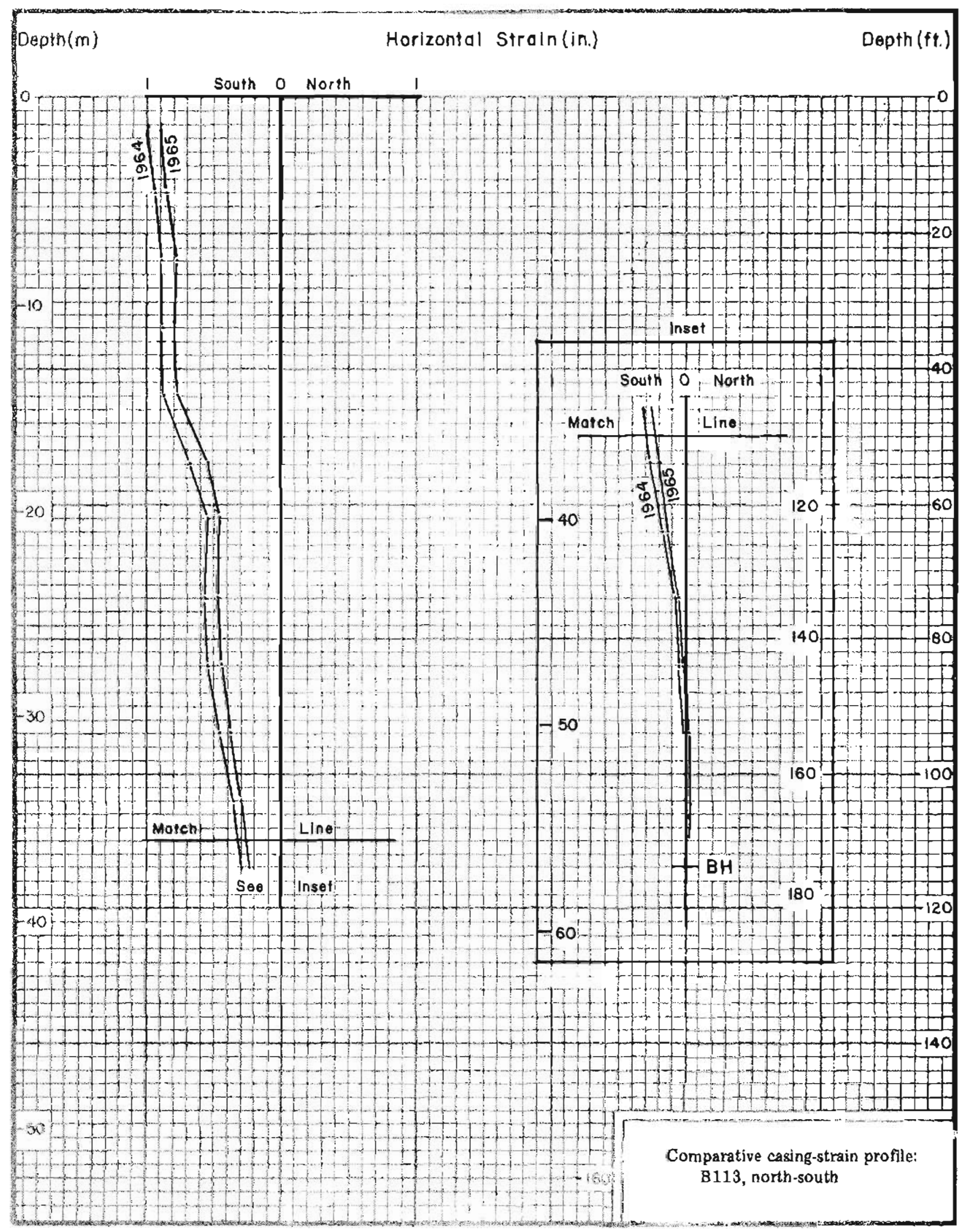




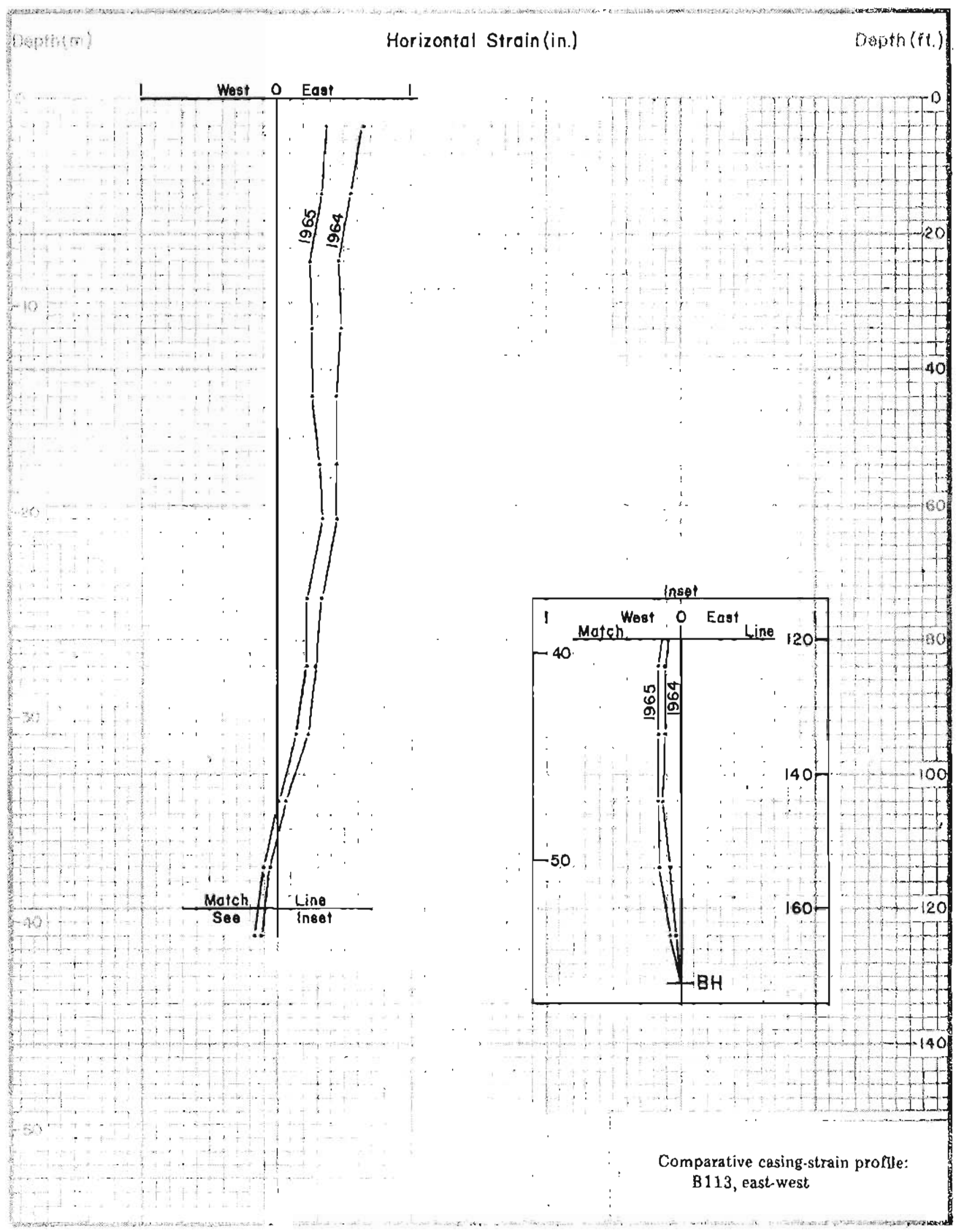




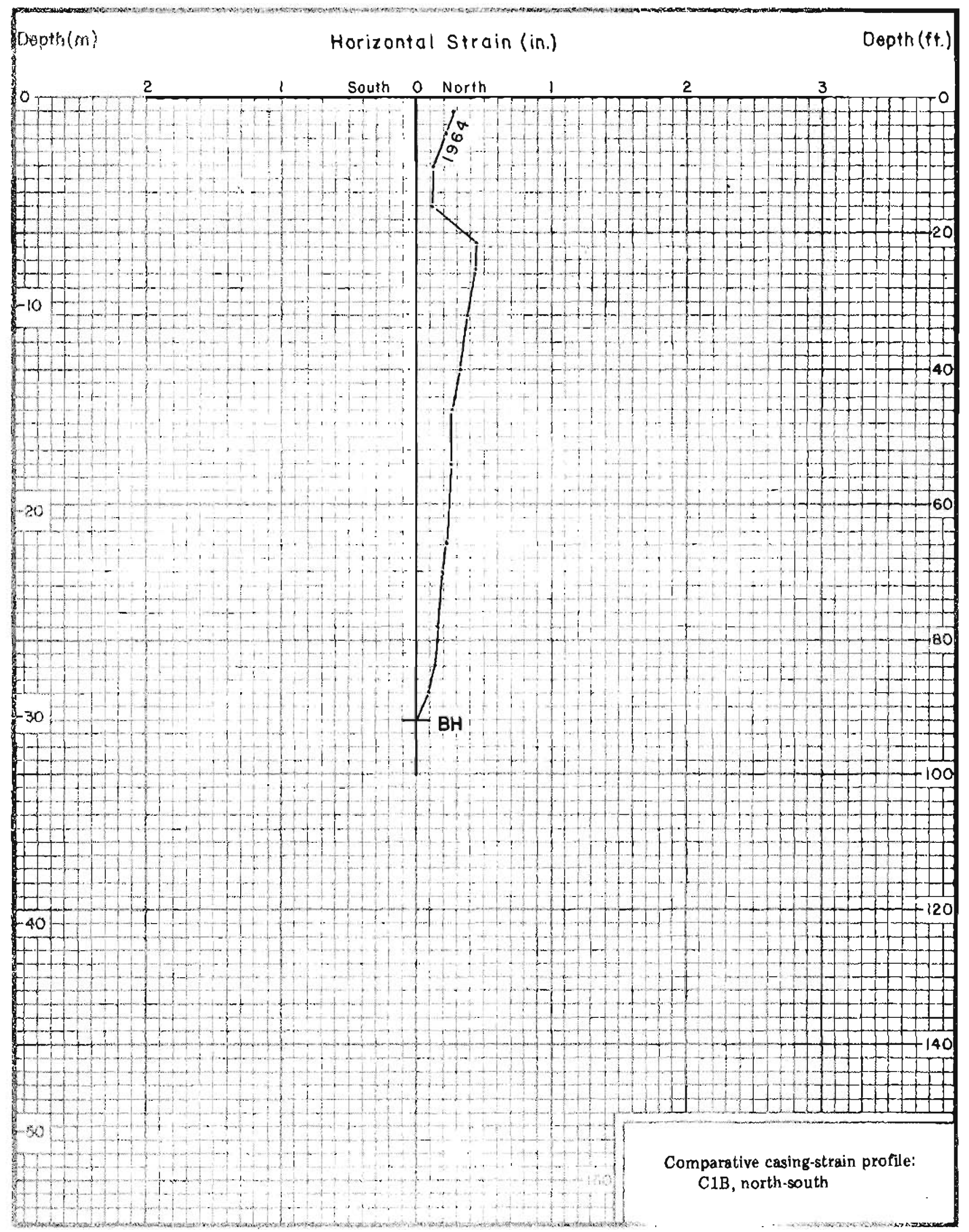




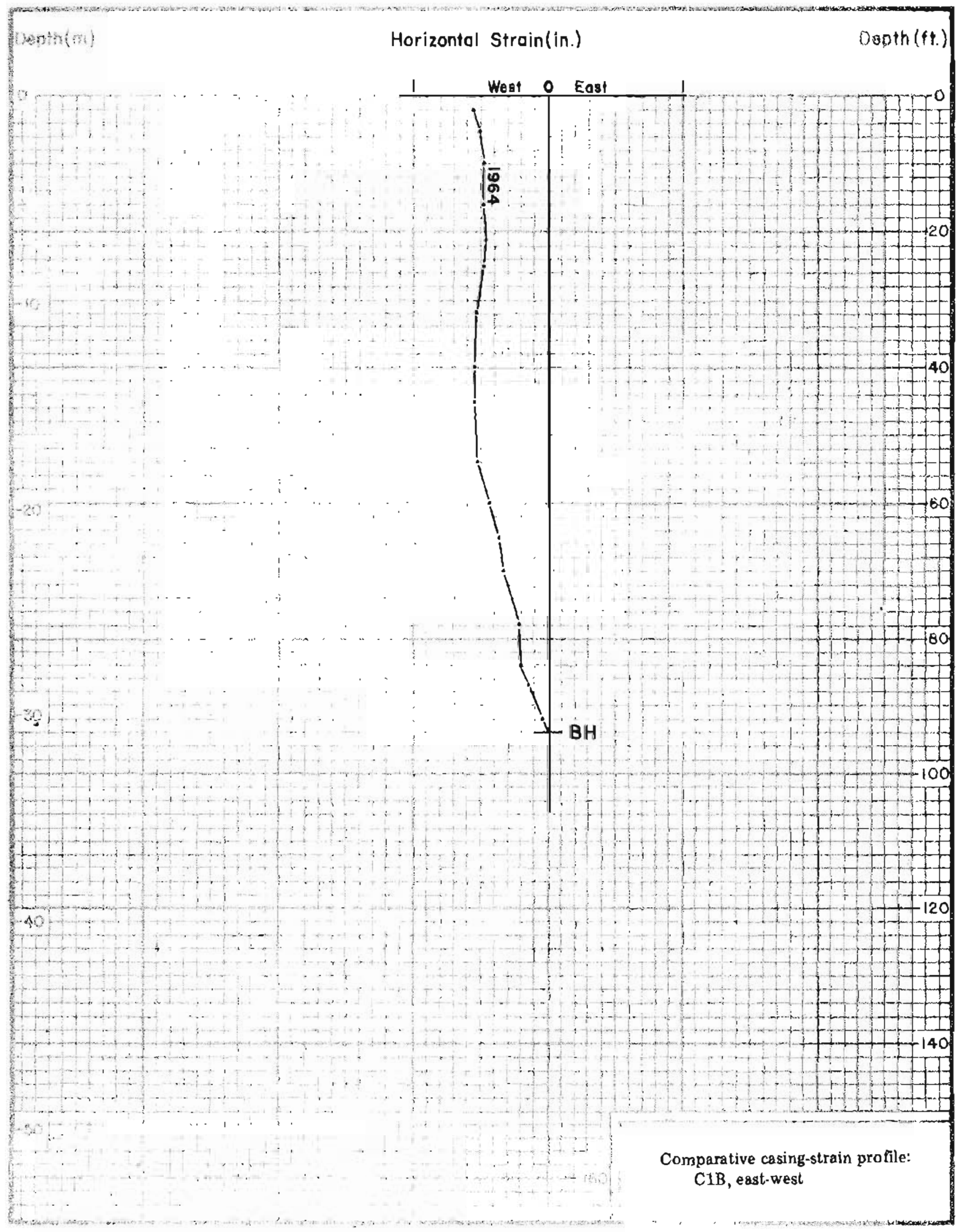




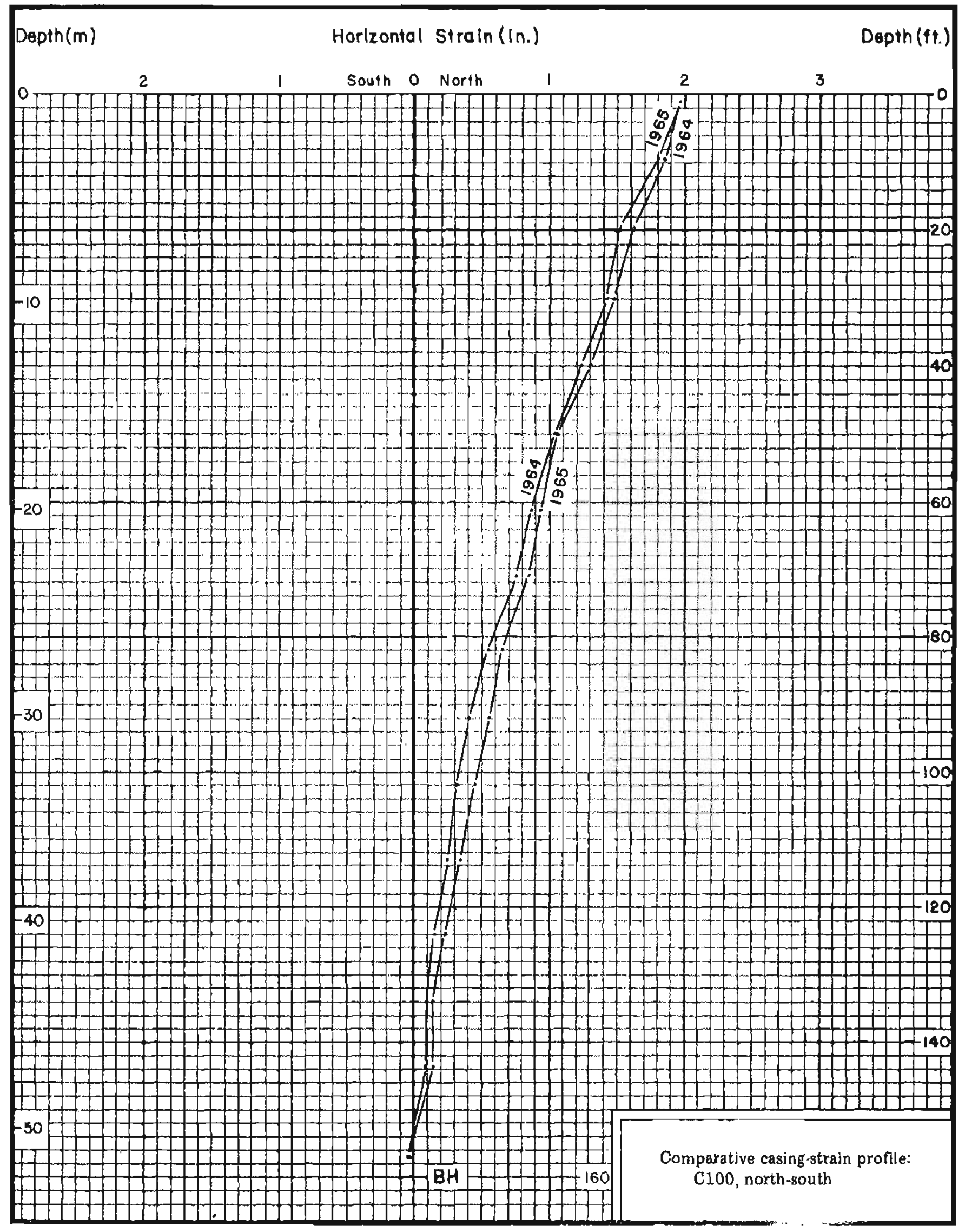




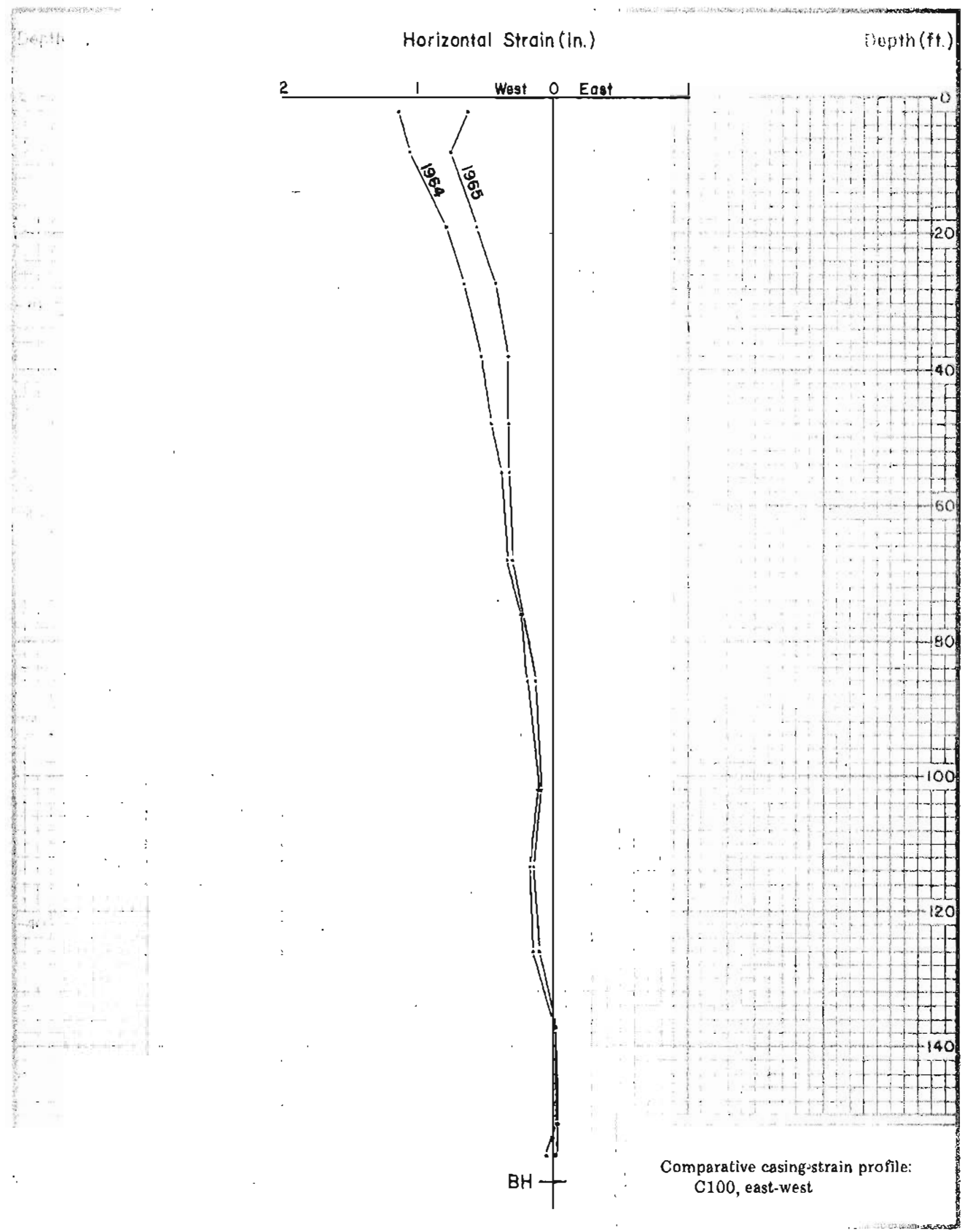




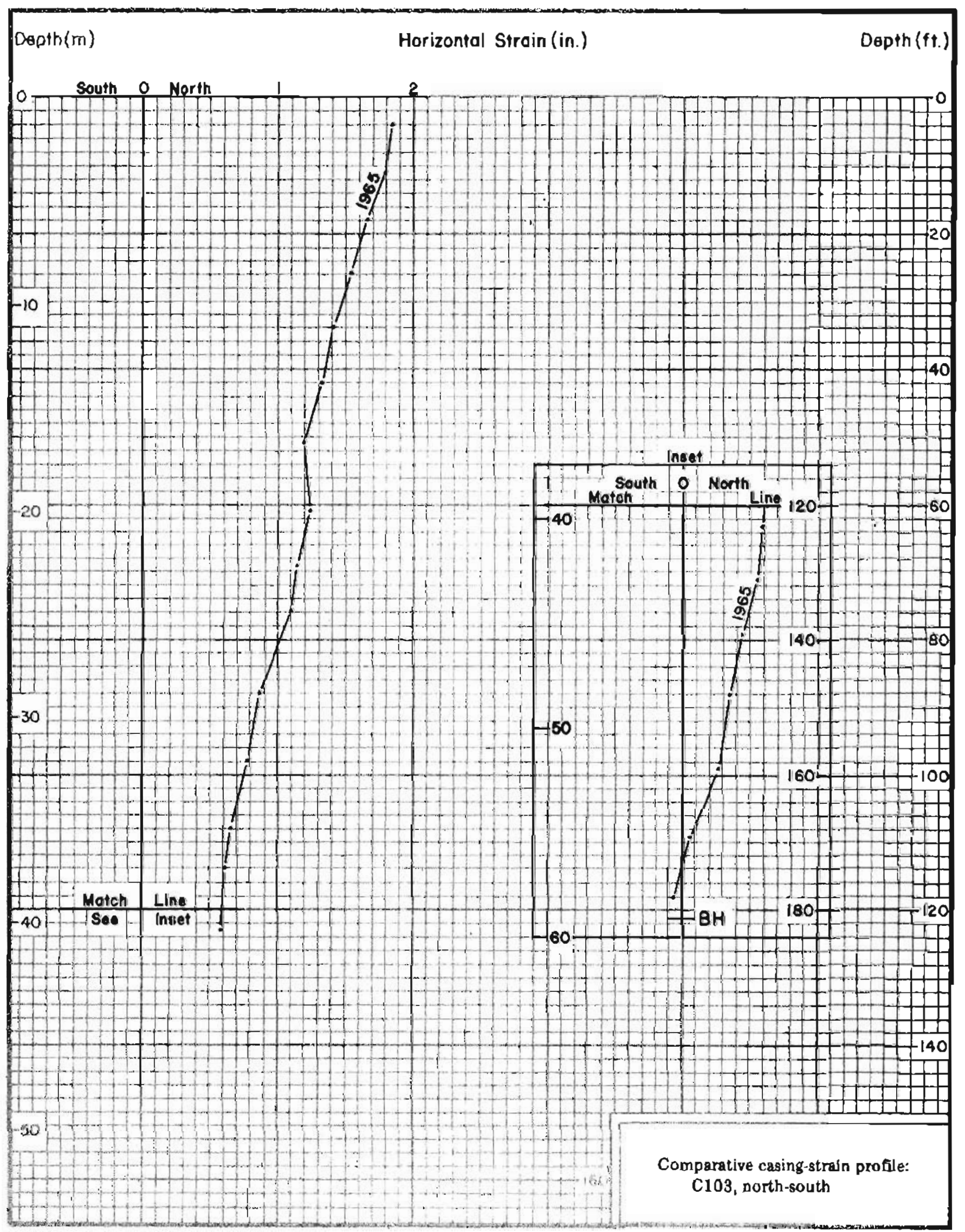




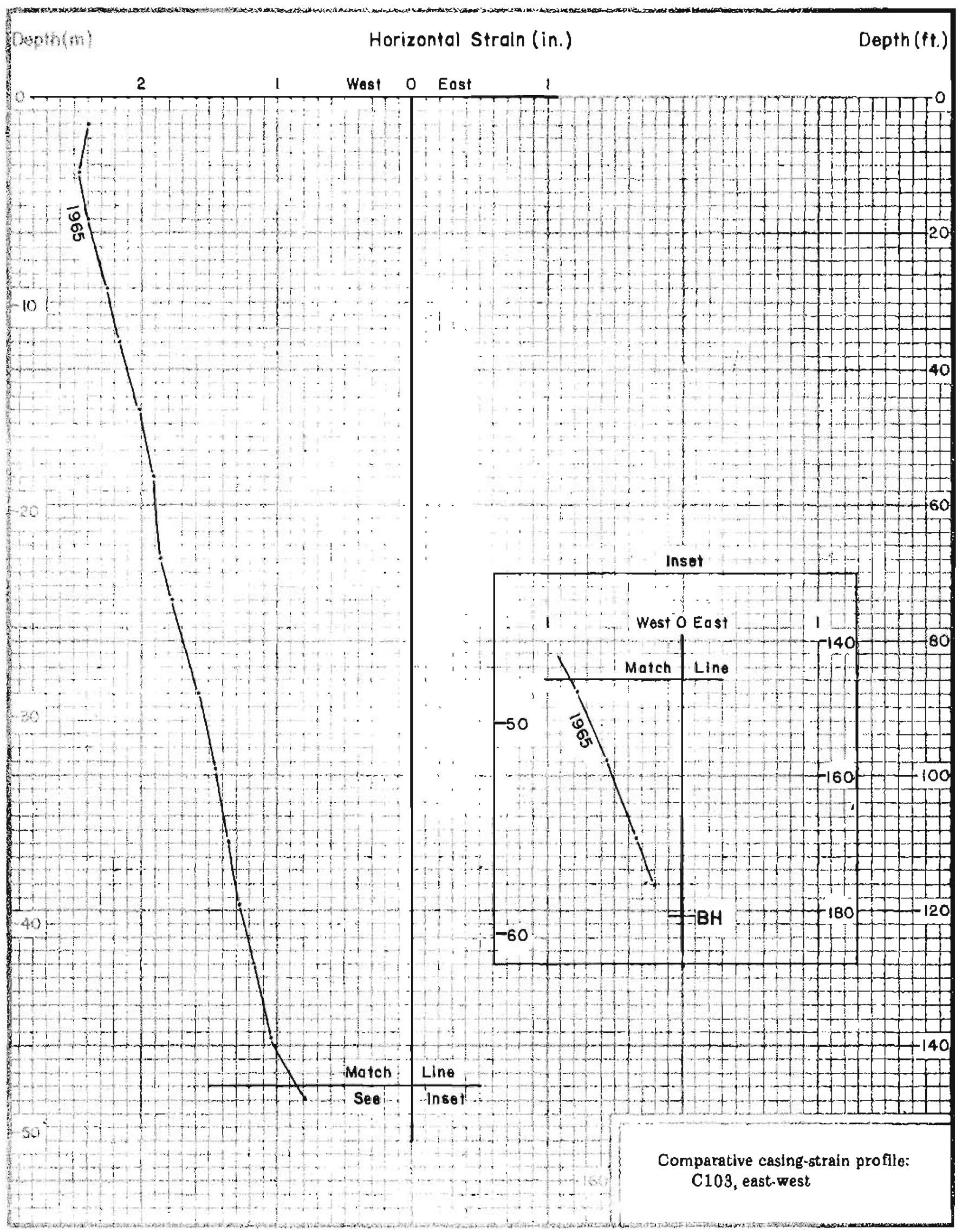




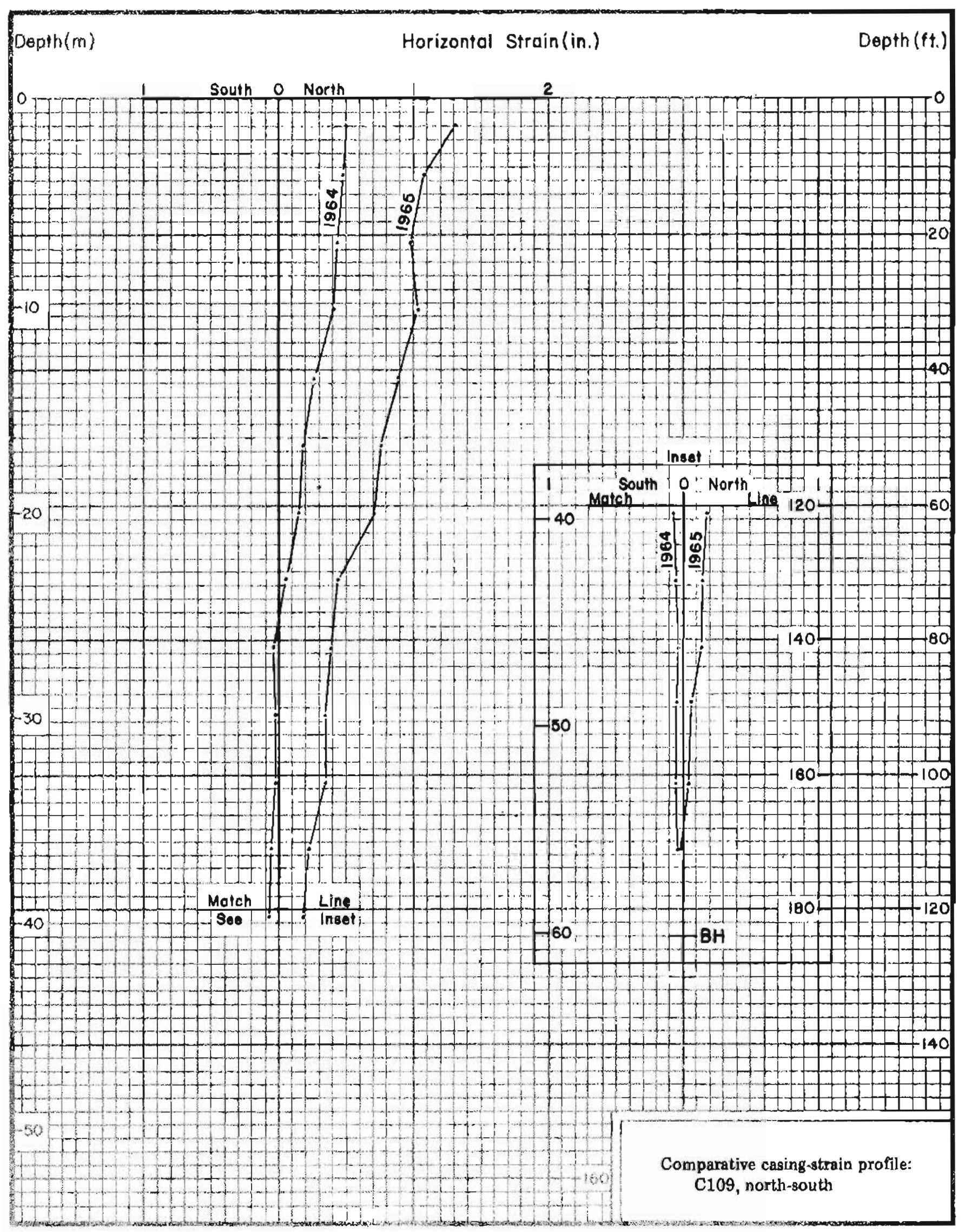




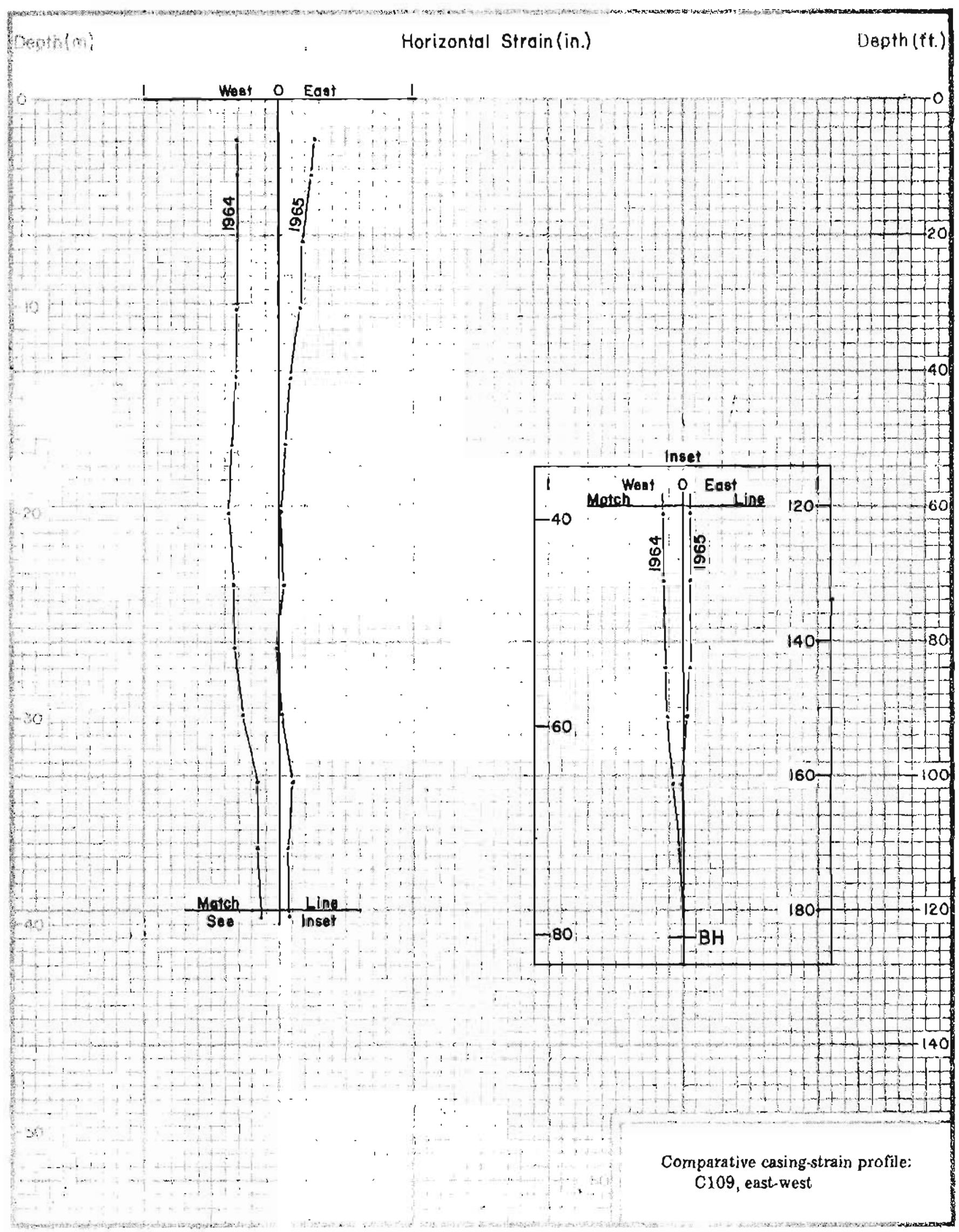




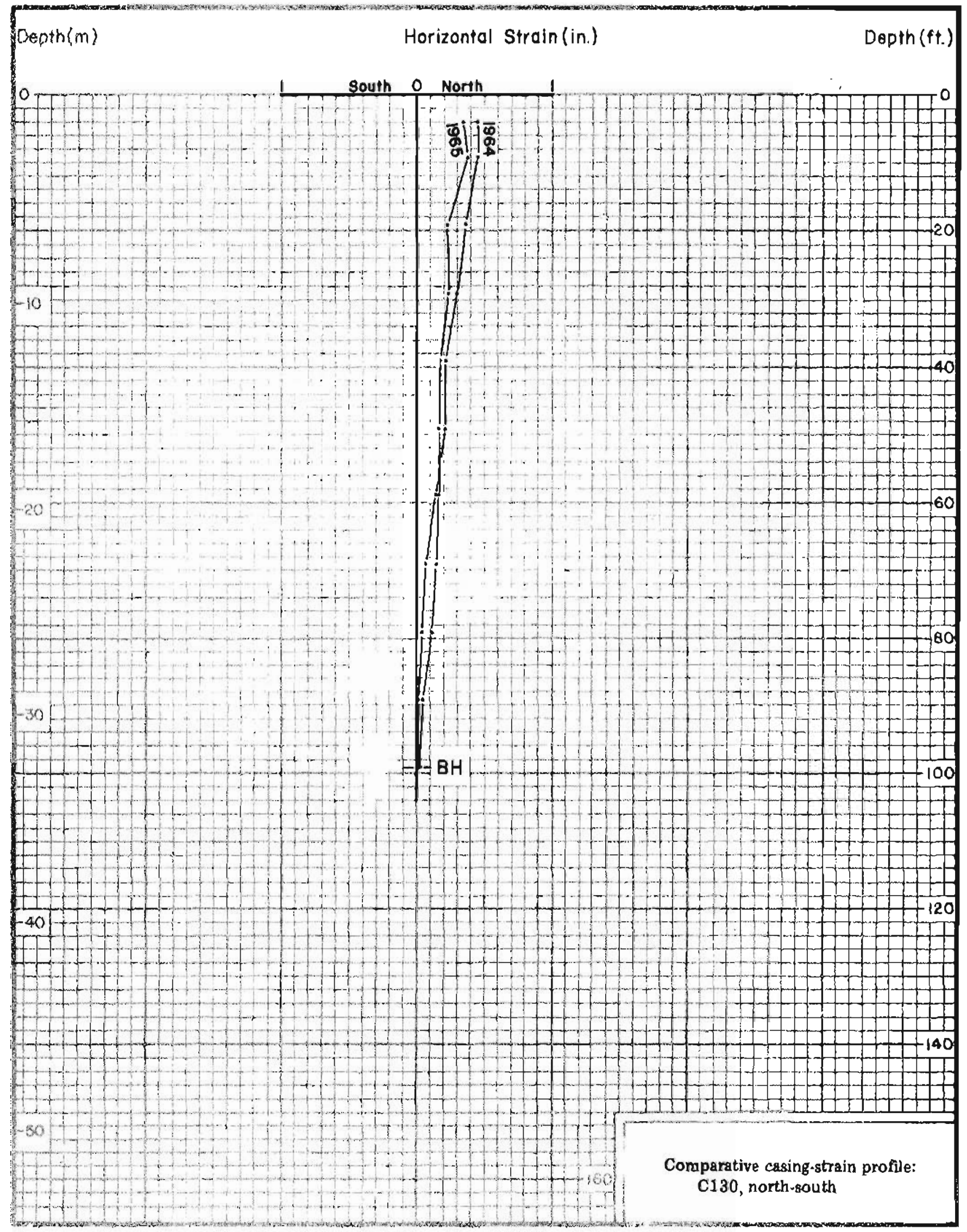




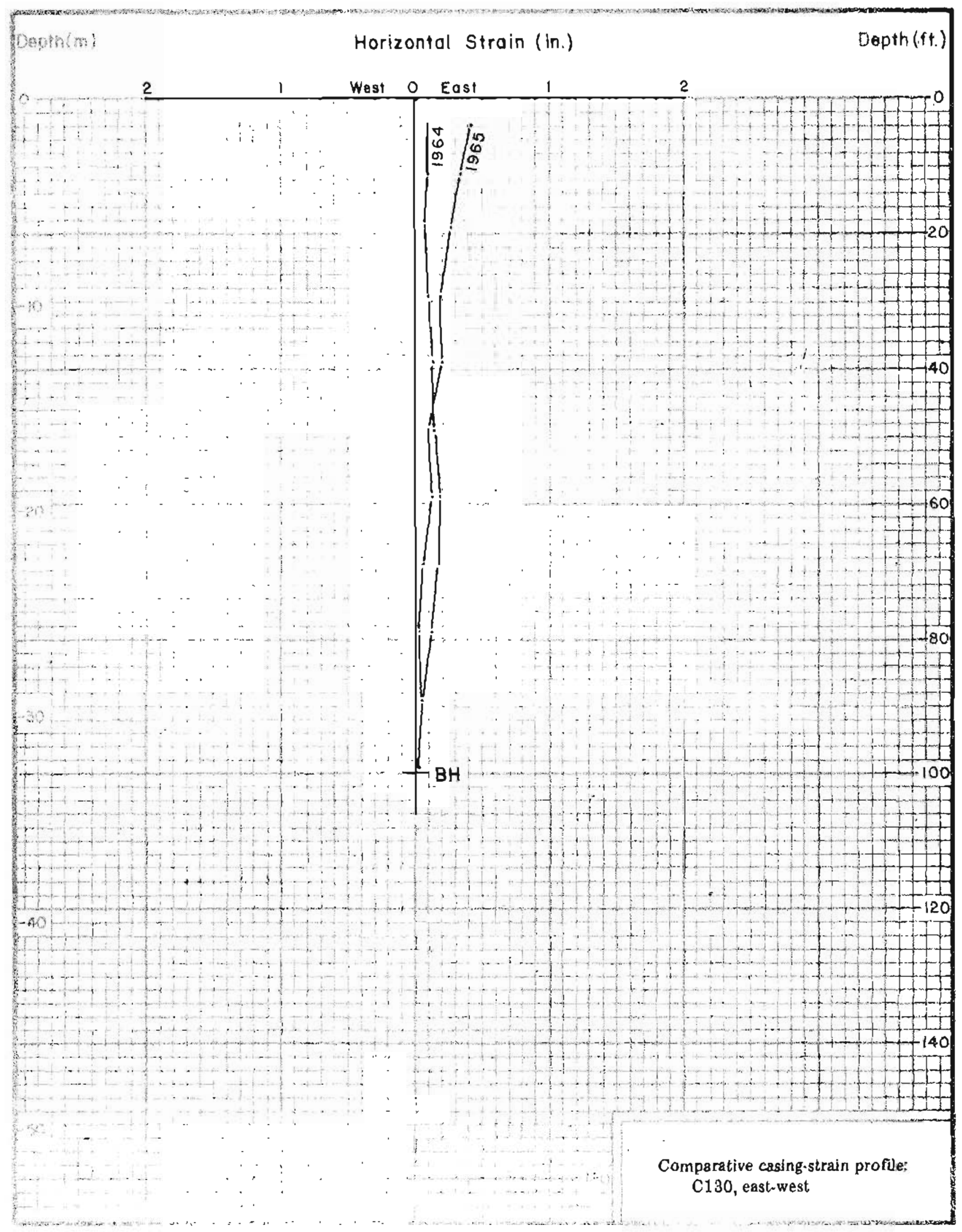


140

INCLINOMETER STRAIN ANALYSES OF ANCHORAGE LANDSLIDES, 1965-80

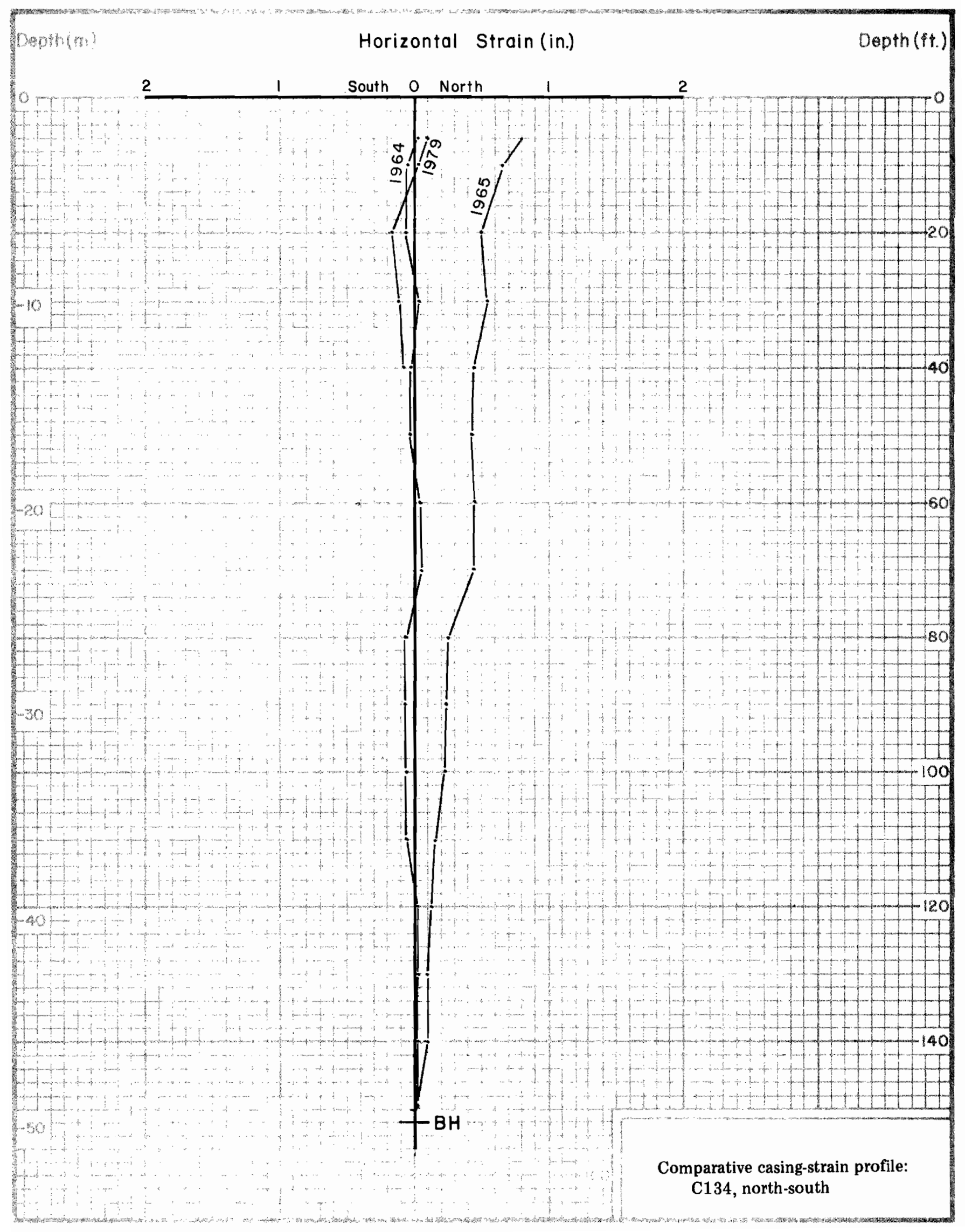




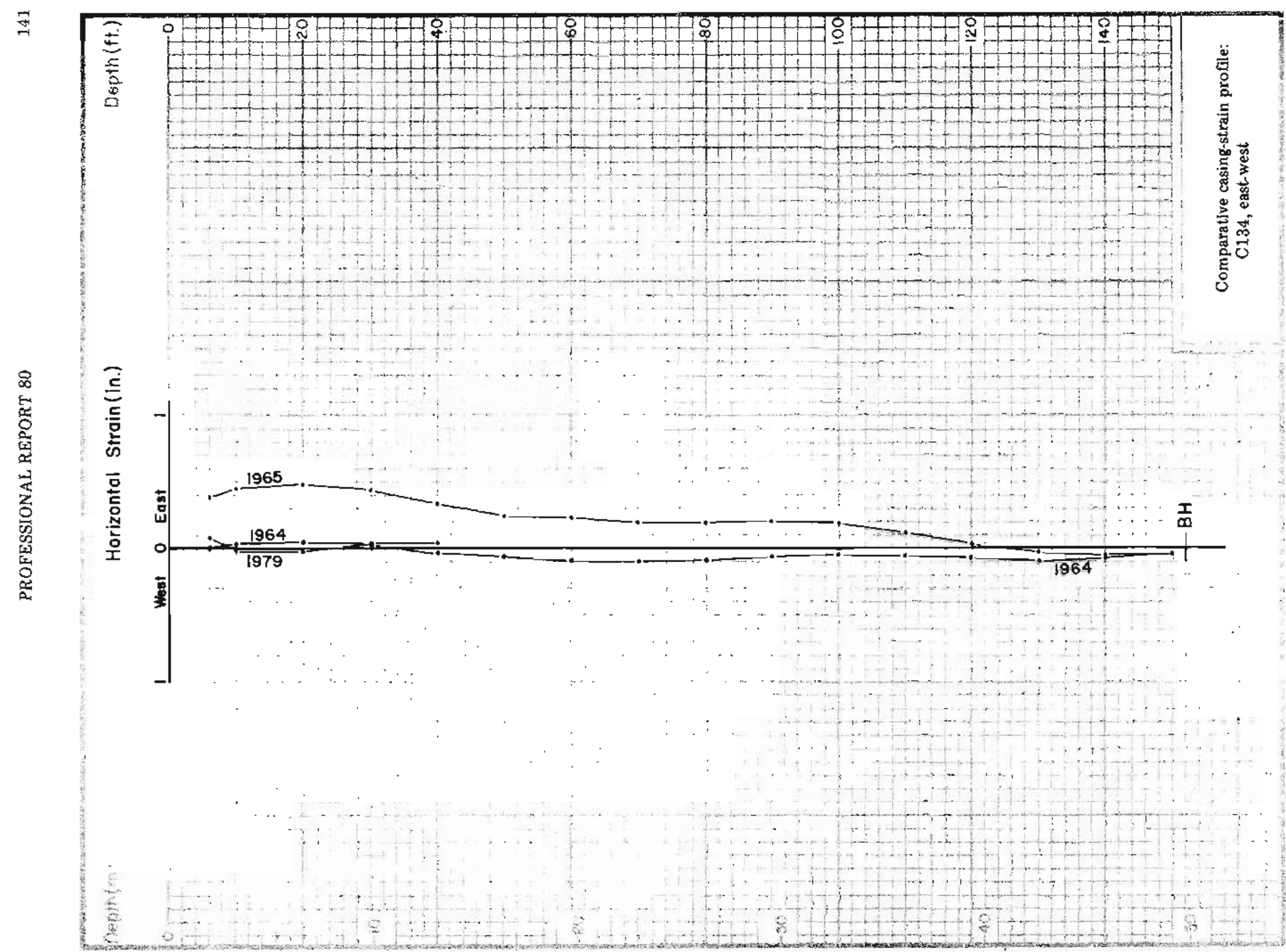


STAFF

Ross G. Schaff, State Geologisl

W.W. Barnwell and W.G. Gilbert, Deputy State Geologists

D.D. Adams, Geological assistant

M.D. Albanese, Geologist

R.D. Allely, Hydrologist

M.A. Armstrong, Publications specialist

M.R. Ashwell, Minerals laboratory technician

B.G. Baldwin, Clerk-typist

E.E. Becia, Planner

T.A. Benjamin, Chemíst

D.L. Bertossa, Geological assistant

J.M. Bird, Clerk-typist

J.D. Blum, Geological assistant

M.E. Brown, Natural resource officer

T.K. Bundtzen, Geologist

C.D. Burgess, Clerk-typist

L.E. Burns, Geological assistant

S.J. Carrick, Hydrologist

S.L. Chambers, Clerk-iypist

M.S. Christy, Geologist

K.H. Clautice, Geological assistant

R.A. Clay, Hydrologist

J.G. Clough, Geologist

E.J. Collazzl, Geological assistant

R.A. Combellick, Geologist

P.L. Coonrod, Secretary

C.L. Danjels, Publications specialist

N.L. Dann, Clerk-typist

J.N. Davies, Geologist

L.L. Dearborn, Hydrologist

J.E. Decker, Geologist

J.T. Dillon, Geologist

R.G. Dixon, Archaeologisi

G.R. Eakins, Geologist

S.J. Garbowski, Geologic information technician

D.E. Gibson, Archaeologist

J.J. Hansen, Geophysicist

M.W. Henning, Geologist

B.S. Huritig, Systems analyst

C.E. Holmes, Archaeologist

M.G. Inghram, Hydrologist

R.W. Ireland, Hydrologist.

S.A. Jacques, Cartographer

J.T. Kline, Geologist

S.L. Klíngler, Archaeologist

R.W. Kornbraih, Geologist

K.J. Krause, Geologist

D.L. Krouskop. Geophysicist

G.M. Laird, Cartographer

E.M. Lamey, Administrative assistant

F.L. Larson, Publications specialist

S.A. Liss, Geological assistant.

T.A. Little, Geologist

W.E. Long, Hydrologist

L.L. Lueck, Geologist

W.M. Lyle, Geologist
C.L. Mahan, Accounting technjcian

R.A. Mann, Clerk

G.D. March, Geologist

M.A. Maurer, Hydrologist

G.A. McCoy, Hydrologist

D.L. McGee, Geologist

R.D. Merrit, Geologist

J.F. Meyer, Geophysicist

C.W. Mishler, Hislorian

M.A. Moorman, Geologìst

R.J. Motyka, Geologist

C.G. Mull, Geologist

J.A. Munter, Hydrologist

D.J. Mursch, Clerk-typist

J.N. Newgard, Accounting technician

K.S. Pearson, Cartographer

G.H. Pessel, Geologist

F.H. Pitts, Administrative officer

M.K. Polly, Minerals laboratory technician

M.E. Pritchard, Cartographer

S.E. Rawlinson, Genlogist

J.W. Reeder, Gealogist

D.R. Reger, Archaeologist

R.D. Reger, Geologisi

V.L. Reger, Geological assistant

R.R. Reifenstuhl, Goological assistant

K.M. Rhoades, Program analyst

M.S. Robinson, Geologist

L.C. Schell, Cartographer

R.D. Shaw, Archaeologist

3.A. Sigler, Land management technician

T.E. Smith, Geologist

T.N. Smith, Geologist

D.J. Solie, Geologist

D.R. Stein, Chemist

R.O. Stern, Archaeologisi

C.H. Stevenson, Geologic information technician

M.J. Stroebele, Clerk-lypist.

A.G. Sturmann, Drafting technician

R.W. Stuvek, Land management technician

8.A. Syvertson, Clerk-typist

C.A. Ulery, Geological assistant

R.G. Updike, Geologist

N.C. Veach, Chemist

R.D. Walkace, Operations research analyst

J.L. Weir, Clerk-typist

S.M. Weum, Geophysicisl

L.W. Wheeler, Clerk-typist

L.P. White, Operations research analyst

D.M. Wietchy, Natural resource of ficer

B.K. Wilson, Geological assistant

M.A. Wiltse, Chemist

G.M. Zartman, Clerk 